\title{
Site U1418
}

\author{
J.M. Jaeger, S.P.S. Gulick, L.J. LeVay, H. Asahi, H. Bahlburg, C.L. Belanger, G.B.B. Berbel, L.B. Childress, \\ E.A. Cowan, L. Drab, M. Forwick, A. Fukumura, S. Ge, S.M. Gupta, A. Kioka, \\ S. Konno, C.E. März, K.M. Matsuzaki, E.L. McClymont, A.C. Mix, C.M. Moy, J. Müller, A. Nakamura, \\ T. Ojima, K.D. Ridgway, F. Rodrigues Ribeiro, O.E. Romero, A.L. Slagle, J.S. Stoner, \\ G. St-Onge, I. Suto, M.H. Walczak, and L.L. Worthington ${ }^{2}$
}

\section{Chapter contents}

Background and objectives. ......... 1

Operations..................... 2

Lithostratigraphy...............4 4

Paleontology and biostratigraphy ...... 10

Stratigraphic correlation. . . . . . . . . 13

Geochemistry ................. 15

Physical properties ............... 19

Paleomagnetism ............... 22

Downhole logging . . . . . . . . . 23

Core-log-seismic integration. . . . . . . . . . 27

References...................... 30

Figures.................... 34

Tables. ....................... 109

1 Jaeger, J.M., Gulick, S.P.S., LeVay, L.J., Asahi, H., Bahlburg, H., Belanger, C.L., Berbel, G.B.B., Childress, L.B., Cowan, E.A., Drab, L., Forwick, M., Fukumura, A., Ge, S., Gupta, S.M., Kioka, A., Konno, S., März, C.E., Matsuzaki, K.M., McClymont, E.L., Mix, A.C., Moy, C.M., Müller, J., Nakamura, A., Ojima, T., Ridgway, K.D., Rodrigues Ribeiro, F., Romero, O.E., Slagle, A.L.,Stoner, J.S., St-Onge, G., Suto, I., Walczak, M.H., and Worthington, L.L., 2014. Site U1418. In Jaeger, J.M., Gulick, S.P.S., LeVay, L.J., and the Expedition 341 Scientists, Proc. IODP, 341: College Station, TX (Integrated Ocean Drilling Program). doi:10.2204/iodp.proc.341.104.2014

'Expedition 341 Scientists' addresses.

\section{Background and objectives}

Site U1418 is located at $3703 \mathrm{~m}$ water depth on a slightly elevated region of the proximal Surveyor Fan. It is located between the Aleutian Trench and an abandoned channel, named here the Bering Channel, which also terminated into the trench when active. These channels appear to originate at the base of the slope seaward of the Bering Trough (Fig. F1). This site lies below the westward-flowing Alaska Current, a boundary current within the Alaska Gyre that commonly contains eddies and meanders (Stabeno et al., 2004). Seasonally high productivity is often associated with these eddies (Ladd et al., 2007). The site has likely been supplied with sediment from gravity flows through these adjacent channels, creating a thick $(\sim 1 \mathrm{~km})$, seismically stratified deposit (Fig. F2). A large deposit of chaotic seismic facies interpreted as a mass transport deposit (MTD) is found at $\sim 5.8 \mathrm{~s}$ two-way traveltime (TWT) (Reece et al., submitted). The top of the MTD forms a reflector that can be mapped to Site U1417, which is dated at $~ 1$ Ma at that site (see "Background and objectives" in the "Site U1417" chapter [Jaeger et al., 2014b]), suggesting that this depocenter may contain an expanded Middle-Late Pleistocene sedimentary sequence.

Drilling objectives at Site U1418 were to develop a high-temporal resolution, proximal sedimentary record of Late Pleistocene glacial-interglacial dynamics, fan sedimentation and development, and paleoceanography. A primary objective of drilling at Site U1418 was to constrain the timing of glacial events of the Pacific side of the northwestern Cordilleran ice sheet to test its relation to dynamics of global ice sheets. This drilling allows for the examination of the timing of sediment gravity flow processes and submarine fan deposition relative to glacial advance-retreat cycles, including the age of the imaged MTD. The observation of an abandoned and buried Bering Channel above the MTD (Fig. F3) suggests that it formed subsequent to the MTD and during the Middle-Late Pleistocene, perhaps as a consequence of changes in glacigenic sediment delivery. An expanded Pleistocene record of glacigenic sediment deposition at Site U1418 also allows for the documentation of the spatial and temporal behavior of the geomagnetic field (paleointensity and paleosecular variation) during this time period in an undersampled region of the globe.

Seismic reflection data crossing Site U1418 and the two alternate sites include high-resolution Profiles GOA3201 and GOA3202 
from the 2004 R/V Maurice Ewing cruise and two crustal-scale St. Elias Erosion and Tectonics Project (STEEP) profiles (Fig. F4; Gulick et al., 2007). A 1989 seismic reflection line (F-6-89-GA-26; Fig. F1) with a vertical resolution in between STEEP07 and GOA3201 and collected by the US Geological Survey $\sim 10 \mathrm{~km}$ northeast of Site U1418 reveals the detailed seismic stratigraphy of the sediment dispersal pathways in this region (Fig. F3). Site U1418 lies at crossing Lines GOA3202 and STEEP07, which reveal a seismically stratified depocenter (Figs. F2, F5). Subhorizontal reflectors of varying intensity are mappable over tens of kilometers, implying deposition from suspension, likely overbank deposition from turbidity currents combined with hemipelagic sedimentation from surface waters. Higher amplitude reflectors may indicate periods of enhanced deposition of ice-rafted sediment and/or coarser sediment gravity flows that are associated with the Bering Glacier.

Seismic units were identified for Expedition 341 to guide core-log-seismic integration (see "Core-logseismic integration") (Fig. F5). All seismic units shallower than the MTD are expected to be correlative subunits of Sequence III at Site U1417 (Reece et al., 2011). Seismic Subunit IIIA is reflective in the higher resolution generator-injector gun data on Line GOA3201. Based on interpretation of Line F-689-GA-26, these reflective facies appear to correlate with levee deposition from the Bering Channel (Figs. F3, F5). Seismic Subunit IIIB is interpreted to represent the cessation of sediment transport through the Bering Channel, possibly corresponding with sediment dispersal into easternmost Aleutian Trench (Fig. F6). In seismic Line F-6-89-GA-26, seismic Subunit IIIA appears to be related to hemipelagic and/or channel overbank deposition from turbidity currents in the Aleutian Trench (Fig. F6). These seismic unit boundaries were therefore primary targets while drilling to the base of Sequence III and the top of the MTD.

\section{Operations \\ Transit to Site U1418}

After a $137 \mathrm{nmi}$ transit from Site U1417 averaging $10.3 \mathrm{kt}$, the vessel arrived at the second expedition site. The vessel stabilized over Site U1418 at $1455 \mathrm{~h}$ (UTC -8 h) on 23 June 2013, and the positioning beacon was deployed at $1515 \mathrm{~h}$.

\section{Site U1418}

Site U1418 consists of six holes (Table T1), ranging in depth from 17.0 to $948.7 \mathrm{~m}$ drillers depth below seafloor (DSF) (Fig. F7). A total of 185 cores were re- covered at the site. The interval cored with the advanced piston corer (APC) system was $810.0 \mathrm{~m}$, with $819.08 \mathrm{~m}$ recovered (101\%). The interval cored with the extended core barrel (XCB) system was $48.5 \mathrm{~m}$, with $22.80 \mathrm{~m}$ recovered $(47 \%)$. The interval cored with the rotary core barrel (RCB) system was 688.7 $\mathrm{m}$, with $495.20 \mathrm{~m}$ recovered $(72 \%)$. The overall recovery for Site U1418 was $86 \%$. Total time spent on Site U1418 was 16.1 days.

\section{Hole U1418A}

Hole U1418A was spudded at $0015 \mathrm{~h}$ on 24 June 2013. The mudline core recovered $4.87 \mathrm{~m}$ of sediment, and the seafloor was calculated to be $3668.2 \mathrm{~m}$ drillers depth below sea level (DSL). Nonmagnetic core barrels and the APC system were used for Cores 341-U1418A-1H through $13 \mathrm{H}$. Temperature measurements were taken with the advanced piston corer temperature tool (APCT-3) shoe on Cores $4 \mathrm{H}, 7 \mathrm{H}$, $10 \mathrm{H}$, and $13 \mathrm{H}$. APC coring with wireline continued through Core $33 \mathrm{H}$ with the half APC coring system using steel core barrels. Partial APC strokes were recorded on Cores $11 \mathrm{H}, 12 \mathrm{H}, 13 \mathrm{H}, 32 \mathrm{H}$, and $33 \mathrm{H}$. Hole U1418A was terminated after Core 33H $(209.9 \mathrm{~m}$ DSF). The drill string cleared the seafloor $1155 \mathrm{~h}$ on 25 June, ending Hole U1418A. A total of 33 piston cores were taken over a $209.9 \mathrm{~m}$ interval, with $216.85 \mathrm{~m}$ recovered $(103 \%)$. Total time spent on Hole U1418A was $45.0 \mathrm{~h}$.

\section{Hole U1418B}

After clearing the seafloor, the vessel was offset $20 \mathrm{~m}$ east of Hole U1418A. Hole U1418B was spudded at $1355 \mathrm{~h}$ on 25 June 2013 . The mudline core recovered $7.57 \mathrm{~m}$ of sediment, and seafloor was calculated to be $3667.5 \mathrm{~m}$ DSL. Nonmagnetic core barrels and the APC system were used for Cores 341-U1418B-1H and $2 \mathrm{H}$. Hole U1418B was terminated after two cores. These cores overlap with a cored interval that was disturbed in the first two cores from Hole U1418A. At the conclusion of coring, the bit was pulled clear of the seafloor, ending Hole U1418B at $1525 \mathrm{~h}$ on 25 June. A total of two piston cores were taken over a $17.0 \mathrm{~m}$ interval, with $17.08 \mathrm{~m}$ recovered (101\%). Total time spent on Hole U1418B was $3.5 \mathrm{~h}$.

\section{Hole U1418C}

After clearing the seafloor, the vessel was offset $20 \mathrm{~m}$ south of Hole U1418B. Hole U1418C was spudded at $2030 \mathrm{~h}$ on 25 June 2013 . The mudline core recovered $8.67 \mathrm{~m}$ of sediment, and seafloor was calculated to be $3666.0 \mathrm{~m}$ DSL. Nonmagnetic core barrels were used and FlexIT orientation was performed for Cores 341-U1418C-1H through $7 \mathrm{H}$. The liner from Core $7 \mathrm{H}$ had to be pumped from the core barrel, and the 
decision was made to drill ahead $2.5 \mathrm{~m}$ and change to the half APC coring system. The hole was advanced from Core $9 \mathrm{H}$ through Core $19 \mathrm{H}$ to $118.2 \mathrm{~m}$ DSF. Core barrels were then switched back to the full stroke, nonmagnetic core barrels, and the hole was advanced through Core $33 \mathrm{H}$ to $230.7 \mathrm{~m}$ DSF. Partial strokes of the coring system occurred on every core after Core $18 \mathrm{H}$, but recovery was adequate until Core $33 \mathrm{H}$. Hole U1418C was terminated at $230.7 \mathrm{~m}$ DSF. The seafloor was cleared at $0710 \mathrm{~h}$ on 27 June, ending Hole U1418C. A total of 32 piston cores were taken over a $228.2 \mathrm{~m}$ interval, with $229.48 \mathrm{~m}$ recovered (100.6\%). Total time spent on Hole U1418C was $39.75 \mathrm{~h}$.

\section{Hole U1418D}

After clearing the seafloor, the vessel was offset $20 \mathrm{~m}$ west of Hole U1418C. Hole U1418D was spudded at $0855 \mathrm{~h}$ on 27 June 2013. An offset water depth of 3666.5 meters below sea level (mbsl) was used after averaging the tide-corrected water depths from the first three holes. After spudding Hole U1418D, the hole was washed down to $3 \mathrm{~m}$ DSF and coring began with Core 341-U1418D-2H and continued with nonmagnetic core barrels through Core $26 \mathrm{H}$ to $230.0 \mathrm{~m}$ DSF. Partial strokes were recorded on Cores $12 \mathrm{H}$, $13 \mathrm{H}, 16 \mathrm{H}$, and $19 \mathrm{H}$ through $29 \mathrm{H}$. After Core $26 \mathrm{H}$, the half APC coring system was deployed, and coring continued to Core $32 \mathrm{H}$ (257.3 m DSF). The XCB coring system was deployed for Cores 33X through 37X to $305.8 \mathrm{~m}$ DSF. Total depth was reached at $0725 \mathrm{~h}$ on 29 June. The drill string was then pulled from the hole, and the seafloor was cleared at $0900 \mathrm{~h}$, ending Hole U1418D. A total of 31 piston cores were taken over a $254.3 \mathrm{~m}$ interval, with $256.97 \mathrm{~m}$ recovered (101\%). A single $3 \mathrm{~m}$ interval was drilled without coring. A total of five XCB cores were cut over a 48.5 $\mathrm{m}$ interval, with $22.8 \mathrm{~m}$ recovered $(47 \%)$. Total core recovery for Hole U1418D was $279.77 \mathrm{~m}$ for the $302.8 \mathrm{~m}$ cored interval (92\%). Total time spent on Hole U1418D was $49.75 \mathrm{~h}$.

\section{Hole U1418E}

After clearing the seafloor, the vessel was offset $20 \mathrm{~m}$ south of Hole U1418D. While servicing the rig, a broken strand of wire was detected on the drilling line. Rather than risk a more severe problem, the decision was made to slip and cut the drilling line to remove the damaged section. Hole U1418D was spudded at $1755 \mathrm{~h}$ on 29 June 2013. A tide-corrected offset depth of 3667.7 mbsl was established for seafloor depth. The hole was advanced to $78.0 \mathrm{~m}$ DSF without coring, and the wash barrel was pulled. APC coring continued for Cores 341-U1418E-2H through $13 \mathrm{H}$ to $181.6 \mathrm{~m}$ DSF. Total depth was reached at 1000 $\mathrm{h}$ on 30 June. After laying out the final core, the drill string was tripped back to $133.4 \mathrm{~m}$ DSF and the top drive was set back. The drill string was then tripped back to surface, and the bottom-hole assembly (BHA) was set back in the derrick. The bit cleared the rotary table at $1900 \mathrm{~h}$, ending Hole U1418E. A total of 11 APC cores were taken over a $100.6 \mathrm{~m}$ interval, with $98.7 \mathrm{~m}$ recovered (98\%). Two intervals were drilled without coring. The first interval was $78.0 \mathrm{~m}$, and the second was $3 \mathrm{~m}$. Total time spent on Hole U1418E was $34 \mathrm{~h}$.

\section{Hole U1418F}

After clearing the seafloor, the vessel was offset $20 \mathrm{~m}$ west of Hole U1418E. Hole U1418F was spudded at $0445 \mathrm{~h}$ on 1 July 2013. A water depth of $3677.0 \mathrm{mbsl}$ was estimated using an offset depth, which was calculated using tide-adjusted depths for the first three holes at the site. After spudding Hole U1418F, the hole was drilled without coring to $260.0 \mathrm{~m}$ DSF. The wash barrel was then pulled, and Cores 341-U1418F$2 \mathrm{R}$ and $3 \mathrm{R}$ were cut to $279.4 \mathrm{~m}$ DSF but were empty when recovered on the rig floor. The core barrel, which had been dropped to cut Core $4 \mathrm{R}$, was retrieved, and a core barrel with a bit deplugger was deployed. RCB coring with nonmagnetic core barrels resumed, and Cores $4 \mathrm{R}$ through $72 \mathrm{R}$ were cut to $948.7 \mathrm{~m}$ DSF. A total of $71 \mathrm{RCB}$ cores were cut over a $688.7 \mathrm{~m}$ interval, with $495.20 \mathrm{~m}$ recovered (72\%).

A total of $265 \mathrm{bbl}$ of high-viscosity mud were used during and at the conclusion of the drilling/coring process in Hole U1418F. Following a short wiper trip from 830.0 to $945.0 \mathrm{~m}$ DSF, an additional $50 \mathrm{bbl}$ sweep of high-viscosity mud was pumped to condition the hole for logging. After pumping the final sweep, the rotary shifting tool was deployed by wireline and the shifting sleeve inside the mechanical bit release was pulled, releasing the bit at the bottom of Hole U1418F. After releasing the bit, the sleeve was shifted back and the top drive was set back. The drill string was then tripped out of the hole, and the end of pipe was set at $98.6 \mathrm{~m}$ DSF for logging.

The triple combo logging string was then rigged up and run into the hole, reaching a total depth of 599 $\mathrm{m}$ wireline log depth below seafloor (WSF) at $2333 \mathrm{~h}$ on 7 July. The Schlumberger wireline winch experienced a transmission problem during the logging run and had to be repaired. The hole was then logged up, and the tools were pulled to surface and rigged down. After rigging down the triple combo tool string, the Versatile Seismic Imager (VSI) tool string was then rigged up and run into the hole. Protective Species Observation watches began at $0900 \mathrm{~h}$ 8 July. No protected marine species were observed within the $940 \mathrm{~m}$ diameter exclusion zone for $1 \mathrm{~h}$, so 
the seismic source (a parallel cluster of two $250 \mathrm{in}^{3}$ Sercel G. Guns) was ramped up. Watches continued throughout the VSI run, with the guns fired manually every $5 \mathrm{~min}$ as the tool string was run into the hole. Once the VSI tool string was in the hole, firing control was delivered to the Schlumberger engineer. Attempts were made to collect data over several hours, but the tool had problems clamping onto the borehole wall. The tool string was pulled out of the hole and back to the surface and rigged down. The guns were secured and the Protective Species Observation watches ceased at $1530 \mathrm{~h}$.

The Formation MicroScanner (FMS)-sonic tool string was then rigged up and deployed to a depth of 582 $\mathrm{m}$ WSF. A single pass was made before the tool string became stuck in the BHA. After trying unsuccessfully to free the tool string, the Kinley crimper was rigged up and deployed to crimp the logging cable inside the BHA before severing the cable. The pressure spike experienced with the line under tension was enough to free the logging tool string, which was then pulled to the surface and rigged down. All logging equipment was rigged down by $0845 \mathrm{~h}$ on $9 \mathrm{July}$, and the knobbies were removed from the drill string. The drill string was then pulled from the hole and the BHA set back and secured for transit at $1630 \mathrm{~h}$ on 9 July, ending Site U1418. Total time spent on Hole $\mathrm{U} 1418 \mathrm{~F}$ was $213.5 \mathrm{~h}$.

\section{Lithostratigraphy}

Lithologic summaries of the six holes drilled at Site U1418 are shown in Figure F8. The sediment recovered at Site U1418 contains 15 facies. Detailed facies descriptions, information about common marine microfossils, facies occurrence in lithostratigraphic units, and tentative interpretations of depositional environments are summarized in Table T2. The dominant facies (F1a, F1b, and F2b) are predominantly gray (N 4) to dark greenish gray (10Y 4/1) mud and interbedded mud and silt and account for $>90 \%$ of the core recovered. The remaining minor facies, although much less volumetrically significant, are distinctive and allow us to organize the cores into lithostratigraphic units. Photographs of the more common facies are shown in Figure F9. Based on characteristic facies associations, four major lithostratigraphic units and four subunits are defined (Table T3).

\section{Facies description}

Fifteen facies were identified and are outlined in Table T2. The numbering of the facies is based on facies documented for all Expedition 341 sites. Lithofacies include massive mud with lonestones (F1a), massive mud without lonestones (F1b), laminated mud (F1c), silt (F2a), interbedded silt and mud (F2b), very fine to coarse sand (F3a), muddy diamict (F4a), interbedded mud and diamict (F4d), diatom ooze (F5a), biosiliceous ooze (F5b), calcareous/carbonate-bearing mud (F5c), volcanic ash (F6), volcaniclastic mud and sand (F7), rock (F8), and intrastratal contorted mud and diamict (F9). These facies reflect deposition from suspension fall out, sediment gravity flows/largescale mass wasting, ice rafting, variation in organic productivity, and volcanic eruptions.

The massive and bioturbated mud of Facies F1a is dark gray (N 4) to dark greenish gray (10Y 4/1) and has bed thicknesses that range from 2.5 to $964 \mathrm{~cm}$ (Table T2). Color banding ranges from gray (N 4) to dark greenish gray (10Y 4/1); individual bands are 0.1 to $5 \mathrm{~cm}$ thick. Bioturbation is mostly absent or slight but occasionally moderate to heavy (Fig. F10JF10K). A diagnostic characteristic of Facies F1a is the absence or low abundance of microfossils. Based on smear slides, the composition of the mud is, on average, $75 \%$ clay-size particles and $25 \%$ silt particles, with no apparent compositional differences between different color bands. Lonestones consist mainly of argillite, siltstone, and metasiltstone, with subordinate amounts of granitoid and sandstone and minor amounts of basalt (greenstone), gabbro, limestone, quartzite, red chert, and rhyolite (Fig. F10A-F10H). Facies F1b is identical to Facies F1a, except for the absence of lonestones (Table T2; Fig. F9A). Facies F1c consists of laminated or bedded greenish gray (10Y 5/1) to dark gray (N 4) mud (Fig. F9B; Table T2). Facies thickness ranges from 0.5 to $485 \mathrm{~cm}$. Bioturbation is generally absent and contacts with other units are gradational. Petrographically, the composition of Facies F1c is similar to that of Facies F1a and F1b. Laminations of Facies F1c are presumably related to slight changes in grain size and/or geochemical composition that are not easily recognizable from smear slide analysis.

Facies F2a consists of thin silt beds (Table T2) that range in color from dark gray $(\mathrm{N} 4)$ to greenish gray (5GY 5/1) and are interbedded with the mud of Facies F1a, F1b, and F1c, respectively. The silt beds have sharp lower contacts and more gradational upper contacts. Individual laminae and bed thicknesses are 0.2 to $7 \mathrm{~cm}$ and often exhibit normal grading. Facies $2 \mathrm{a}$ is often well sorted. The framework grain composition of this facies is almost entirely quartz and feldspar with minor amounts of heavy minerals based on smear slide analysis. Accessory framework grains include biotite and hornblende. Quartz in Fa- 
cies F2a is monocrystalline, and few lithic grains were documented. Facies F2b consists of dark gray $(\mathrm{N}$ 4) to very dark gray ( $\mathrm{N} 3$ ) interbedded/interlaminated silt and mud (Fig. F9D, F9G). Facies thickness ranges from 3 to $1067 \mathrm{~cm}$, and up to 50 laminae per core section were documented. Lower contacts of silt laminae are most often sharp. Upper contacts are sharp or gradational. Bioturbation is none to slight, and lonestones are present in low abundance.

Facies F3a (Table T2) consists of dark gray (N 4) to gray (N 5) fine to coarse sand (Fig. F9E). This facies often has a sharp lower contact and a gradational upper contact. Bed thickness commonly ranges from 1 to $11 \mathrm{~cm}$, but maximum bed thickness is $38 \mathrm{~cm}$. The sand has a muddy matrix, is poorly sorted, and sometimes contains minor amounts of diatom fossils and volcanic ash. The composition of framework grains of sand is mainly quartz and feldspar with few lithic grains identified in smear slides. Quartz in Facies F3a is mainly monocrystalline. Heavy minerals are minor but consistent constituents.

Facies $\mathrm{F} 4 \mathrm{a}$ is a dark gray (N 4) diamict that has variable clast concentration (Table T2; Fig. F9I-F9J). Common clast sizes are granule and pebble, with clasts being subangular to subrounded. Common clast types are argillite, siltstone, metasiltstone, granitoid, sandstone, basalt (greenstone), gabbroic, chert, and rhyolite (Fig. F10A-F10H). Based on smear slides, the composition of the sand fraction is primarily quartzofeldspathic and the mud fraction is typically $35 \%$ silt and $65 \%$ clay-size particles. Beds of this facies thickness are 2 to $1435 \mathrm{~cm}$. Interbedded mud and diamict define Facies F4d (Table T2; Fig. F9H). This facies is characterized by laminated mud, with diamict beds up to $4 \mathrm{~cm}$ thick. Maximum clast size in the diamict is $2 \mathrm{~cm}$. Clast types in the diamict are similar to those described for Facies F4a. The contacts between the mud and diamict interbeds in Facies $\mathrm{F} 4 \mathrm{~d}$ are gradational in most cases. Intervals of this facies are 12 to $441 \mathrm{~cm}$ thick. It is often color banded, with the diamict forming the darker parts of the color banding and the laminated mud the lighter parts.

Facies F5a is composed of diatom ooze (Table T2; Fig. F9C). By definition, lithostratigraphic units within this facies contain $>50 \%$ diatoms (see "Lithostratigraphy" in the "Methods" chapter [Jaeger et al., 2014a]). The remaining constituents in this facies are typically mud, and in some cases, calcareous mud was documented. Contacts vary between gradational and sharp. The distinction between Facies F5a and F1a, F1b, and F1c can be very subtle and only recognizable by the documentation of diatoms in smear slides. Bed thickness for Facies F5a varies from 3 to $291 \mathrm{~cm}$. Bioturbation and black mottling is common. The biosiliceous ooze of Facies F5b is similar to the characteristics described for Facies F5a, except that the biogenic material consists of some combinations of diatoms, sponge spicules, radiolarians, and/ or nannofossils. Facies F5c is dark gray (N 4) calcareous/carbonate-bearing mud (Table T2). This facies includes calcareous-rich laminae as thick as $0.2 \mathrm{~cm}$, as well as larger intervals with calcareous-bearing mud. It can be as thick as $\sim 195 \mathrm{~cm}$.

Facies F6 is defined by gray (5Y 4/1) to brown (5YR 5/3) volcanic ash (Table T2; Fig. F9F). Bed contacts range from sharp to gradational. Compositionally, this facies consists of $90 \%$ glass shards (vitric fragments). The remaining framework grains are feldspar, quartz, and opaque minerals. In intervals of heavy bioturbation, the ash becomes mixed with the underlying and overlying mud and is sometimes concentrated in burrows. Volcaniclastic mud and sand define Facies F7 (Table T2). Bed thickness commonly ranges from 0.5 to $558 \mathrm{~cm}$. These beds consist of a mixture of volcanic glass (typically 10\%-20\%), quartz, feldspar, and often diatom microfossils. Facies F7 is often bioturbated. Facies F8 consists of 1-6 $\mathrm{cm}$ thick intervals of lithified siltstone with calcite cement (Fig. F10I) that most probably reflects in situ precipitation of calcite related to diagenesis.

Facies F9 consists of intrastratal contorted mud and diamict (Table T2; Fig. F11). Very dark greenish gray (10Y 3/1) mud mixed with very dark gray (N 3) muddy diamict with variable clast content are the two major lithologies (Fig. F11A-F11B). We merged these two lithologies into one facies category because of the common occurrence together and limited extent (Cores 341-U1418F-70R through 72R). Facies F9 is characterized by soft-sediment deformation and contorted bedding (Fig. F11A). Contorted mud occurs in beds with thicknesses of $50-100 \mathrm{~cm}$, whereas muddy diamict occurs in beds that average $20-40 \mathrm{~cm}$. Contacts between the two lithologies appear to be gradational. There is a range of soft-sediment deformation fabrics, including

- A flow slurry where the long axis of centimeterscale intraformational clasts are oriented parallel to the fabric in the lighter colored, finer grained matrix (Fig. F11C). This fabric has well-defined flow lineation. In some cases, clasts form a greater proportion than the matrix, and in other cases, clasts and matrix are in roughly equal proportions.

- A mud breccia where angular clasts of mud are separated by smaller amounts of lighter colored 
matrix (Fig. F11D). This fabric does not display well-developed flow lineation, and clasts are much more common than matrix.

- A flow-parallel fabric defined by laminated millimeter-scale bands of mud with internal evidence of soft-sediment deformation that contains no intraformational clasts (Fig. F11E).

Common clast types in the diamict of Facies 9 are rhyolite, basalt (greenstone), siltstone, sandstone, argillite, quartz, gneiss, and granite (Fig. F11B). Clasts are typically subrounded, but some smaller clasts are subangular; the largest clast diameters average $2 \mathrm{~cm}$. The diamict contains a wide range of grain sizes with a mud-rich matrix. Smear slide analysis indicates that the mud is poorly sorted, a mixture of silt and clay grain sizes. Normal faults are common in this unit (Fig. F11F-F11G); these faults commonly have $<2 \mathrm{~cm}$ of displacement. Some of these faults are at a high angle to surrounding beds, and others are at a low angle. A few rare lonestones were identified in this unit.

\section{Lithostratigraphic units}

Based on facies associations, four major lithostratigraphic units (I-IV) are defined (Table T3). Unit II is further divided into Subunits IIA-IID based on the characteristics of diamict intervals. The contacts between lithostratigraphic units at Site U1418 are usually gradational, and the criteria used to define units are discussed below.

\section{Unit I}

Intervals: $341-\mathrm{U} 1418 \mathrm{~A}-1 \mathrm{H}-1,0 \mathrm{~cm}$, to $33 \mathrm{H}-\mathrm{CC}, 25$ $\mathrm{cm}$; 341-U1418B-1H-1, $0 \mathrm{~cm}$, to $2 \mathrm{H}-\mathrm{CC}, 16 \mathrm{~cm}$; 341-U1418C-1H-1, $0 \mathrm{~cm}$, to $32 \mathrm{H}-\mathrm{CC}, 18 \mathrm{~cm}$; $341-\mathrm{U} 1418 \mathrm{D}-2 \mathrm{H}-1,0 \mathrm{~cm}$, to $32 \mathrm{H}-\mathrm{CC}, 24 \mathrm{~cm}$; $341-\mathrm{U} 1418 \mathrm{E}-2 \mathrm{H}-1,0 \mathrm{~cm}$, to $13 \mathrm{H}-\mathrm{CC}, 14 \mathrm{~cm}$

Depths: Hole U1418A $=0-209.9 \mathrm{~m}$ core depth below seafloor (CSF-A); Hole U1418B = 0-17.0 m CSF-A; Hole U1418C $=0-230.76$ m CSF-A; Hole $\mathrm{U} 1418 \mathrm{D}=3.0-257.3 \mathrm{~m}$ CSF-A; Hole U1418E = 78.0-181.6 m CSF-A

Age: Middle Pleistocene to Holocene

Dark gray (N 4) to dark greenish gray (10Y 4/1) mud with interbedded silt alternates with intervals as thick as $15.5 \mathrm{~m}$ of color-banded dark gray (N 4) mud (Table T3; Fig. F9A-F9B). Silt laminae are commonly $<5 \mathrm{~mm}$ thick and occur in groups of between 5 and 34 laminae at variable spacing within the mud (Fig. F9D). Bioturbation is mostly absent or slight. Diatom ooze occurs in two broad intervals, at the top of the hole and sporadically from 100 to $200 \mathrm{~m}$ core composite depth below seafloor (CCSF-B) (Fig. F12). Diatom-bearing to diatom-rich mud occurs within nu- merous cores (see Fig. F8 unit descriptions for specific cores). Each interval with diatoms has gradational contacts and greater bioturbation intensity, and black mottling is often present. Graded sand beds with sharp lower contacts (Fig. F9E) occur infrequently. Five ash beds are present, and volcaniclastic-bearing to volcaniclastic-rich mud occurs in irregular patches. Lonestones appear deeper than $3 \mathrm{~m}$ CSF-A and are present throughout. Common lithologies of the lonestones are siltstone, metasediment, and igneous rock (Fig. F10A-F10H).

\section{Unit II}

This unit is dominated by mud interbedded with intervals of clast-poor diamict that range in thickness from a few centimeters to $>1 \mathrm{~m}$. Mud with clast concentrations ranging from dispersed to abundant is also present. Unit II extends over $546 \mathrm{~m}$ at Site $\mathrm{U} 1418$ and is divided into four subunits based on the relative thickness and occurrence of the diamict facies within the mud facies.

\section{Subunit IIA}

Intervals: $341-\mathrm{U} 1418 \mathrm{D}-32 \mathrm{H}-\mathrm{CC}, 24 \mathrm{~cm}$, to $37 \mathrm{X}$ CC, $43 \mathrm{~cm}$; 341-U1418F-4R-1, $0 \mathrm{~cm}$, to 9R-5, 70 $\mathrm{cm}$

Depths: Hole U1418D = 257.3-297.93 m CSF-A; Hole U1418F = 279.4-334.6 m CSF-A

Age: Middle Pleistocene

Subunit IIA contains dark gray (N 4) to dark greenish gray (10Y 4/1) muddy diamict with generally lower clast abundance (Fig. F9I) interbedded with dark gray (N 4) mud, as well as mud with dispersed clasts. Contacts between beds appear gradational. The mud is weakly laminated. Coarse sand, granules, and lonestones of variable composition occur within the diamict and mud.

\section{Subunit IIB}

Interval: 341-U1418F-9R-5, $70 \mathrm{~cm}$, to 44R-1, 111 $\mathrm{cm}$

Depth: Hole U1418F = 334.6-668.5 m CSF-A

Age: Middle Pleistocene

Dark gray (N 4) to dark greenish gray (10Y 4/1) laminated mud with layering ranging from submillimeter (a few coarse silt grains) to $4 \mathrm{~mm}$ is interbedded with mud with dispersed clasts and diamict with generally low clast content (Fig. F9H). Commonly, laminae occur in packages of variable thickness bounded with gradational contacts by thin beds of diamict with generally low clast content forming interbedded mud and diamict facies. Some intervals are calcareous bearing, as seen in smear slides, and may include authigenic carbonate and in some cases foraminifers. 
Volcanic ash occurs as burrow fills and in dispersed intervals of moderate to heavy bioturbation. Lonestones occur throughout. A few normal faults with $<1 \mathrm{~cm}$ of displacement were documented in this unit (Fig. F10N).

\section{Subunit IIC}

Interval: $341-\mathrm{U} 1418 \mathrm{~F}-44 \mathrm{R}-1,111 \mathrm{~cm}$, to $47 \mathrm{R}-\mathrm{CC}$, $19 \mathrm{~cm}$

Depth: Hole U1418F $=668.5-706.2 \mathrm{~m}$ CSF-A

Age: early Pleistocene

Subunit IIC contains very dark greenish gray (10Y 4/ 1) massive clast-poor diamict interbedded with mud. Thirteen diamict intervals with gradational contacts occur, ranging from 30 to $150 \mathrm{~cm}$ in thickness. Mud is massive, thinly color banded, or laminated. Diatom ooze occurs in Section 341-U1418F-46R-2A (Fig. F9C). Moderate bioturbation occurs in the diamict. Volcanic ash is present in bioturbated mud and ooze. Lonestones occur within the mud.

\section{Subunit IID}

Interval: 341-U1418F-48R-1, $0 \mathrm{~cm}$, to $58 \mathrm{R}-1,10 \mathrm{~cm}$ Depth: Hole U1418F = 706.2-803.3 m CSF-A

Age: early Pleistocene

Subunit IID contains very dark greenish gray (10Y 4/ 1) to dark gray (N 4) laminated mud with some color banding interbedded with thin-bedded diamict with generally lower clast content (Fig. F9H). Gravel and coarse sand occur in beds a few centimeters thick with gradational contacts. Stratification varies from millimeter-scale lamination to thin bedded. Lonestones are scattered throughout. Section 341U1418F-50R-1A contains small-scale ripple stratification (Fig. F10L). Sections 50R-2A and 3A contain two slump features that are $\sim 50 \mathrm{~cm}$ in individual thickness and result in discordant bedding orientations relative to the horizontal bedding in the rest of the core (Fig. F10O-F10P). These cores also contain minor unconformities recognized by erosional surfaces and/or slightly discordant bedding (Fig. F10M).

\section{Unit III}

Interval: 341-U1418F-58R-1, $10 \mathrm{~cm}$, to 70R-1, $0 \mathrm{~cm}$ Depth: Hole U1418F = 803.3-919.6 m CSF-A

Age: early Pleistocene

Laminated and bioturbated dark gray (N 4) mud is the dominant lithology. Thinly bedded very dark gray (N 3) sandstone and gray (N 6) siltstone are minor but distinctive components. Two $10 \mathrm{~cm}$ thick beds of diamict with generally higher clast content containing rip-up clasts occur near the base of the unit. Minor units often have calcareous cement. Thin intervals of well-cemented carbonate mud, as well as small numbers of lonestones, occur throughout this unit (Fig. F10I). Microfossils are rare in this unit based on smear slide analysis. Ash is also rare, but a well-preserved example was documented in interval 341-U1418F-58R-5A, 83-89 cm (Fig. F9F). Although volcaniclastic-bearing to volcaniclastic-rich mud was documented in Units II and III, Core 58R contains the only occurrence of a bed of $>90 \%$ ash. Other ash falls appear to have been bioturbated into the surrounding mud, leaving discontinuous mixed pods.

\section{Unit IV}

Interval: 341-U1418F-70R-1, $0 \mathrm{~cm}$, to 72R-CC, 21 $\mathrm{cm}$

Depth: Hole U1418F = 919.6-941.4 m CSF-A

Age: early Pleistocene

Very dark greenish gray (10Y 3/1) mud mixed with a very dark gray (N 3) muddy diamict with generally higher clast content are the two major lithologies (Fig. F11A, F11C). Both lithologies are characterized by soft-sediment deformation and intrastratal contortions (Fig. F11A-F11E). Convoluted gray mud occurs in beds with thicknesses of 50-100 cm, whereas muddy diamict occurs in beds that are, on average, $20-40 \mathrm{~cm}$ thick. Contacts between the two lithologies appear to be gradational. A range of soft-sediment deformation fabrics is discussed in the description of Facies F9. Normal faults are common in this unit (Fig. F11F-F11G). A few rare lonestones were identified.

\section{Clast lithologies}

\section{Petrography}

The main lithologies of the diamict clasts and lonestones contained in Site U1418 sediment are, in order of decreasing abundance, argillite, siltstone, basalt, sandstone, granitoid, and limestone (Fig. F10A$\mathrm{F} 10 \mathrm{H})$. The granitoid group includes intermediate and felsic intrusive rocks. Gabbros represent a minor lithology, as do quartzite, metasiltstone, chert, rhyolite, gneiss, and diorite. These lithologies are unevenly distributed in Holes U1418A-U1418F. Composition for each hole and the site is determined according to the main lithology types, metamorphic (M), sedimentary (S), and igneous (I) (Fig. F13), and reveal variation between holes and also the predominance of metamorphic and sedimentary lithologies over igneous. The average clast ratio for Site U1418 is $\mathrm{M}_{39} \mathrm{~S}_{23} \mathrm{I}_{38}$.

\section{Bulk mineralogy}

$\mathrm{X}$-ray diffraction (XRD) analyses were performed on 108 powdered bulk samples from Holes U1418A, 
U1418D, and U1418F to delineate bulk mineralogy and identify compositional trends with age or depth in the cores. Representative diffraction patterns are shown in Figure F14, and the relative mineral diffraction peak intensities, as defined in "Lithostratigraphy" in the "Methods" chapter (Jaeger et al., 2014a), are listed in Table T4. In general, the mineralogy is uniform downhole, although there are some variations in relative peak intensities that may indicate slight variations in mineral content. The primary minerals identified include quartz, plagioclase (feldspar), mica (muscovite/illite and biotite), and the minerals chlorite and/or kaolinite (Fig. F14A). Quartz and plagioclase are the dominant peaks, with quartz generally the larger. Figure F14B shows the comparative XRD patterns from $4^{\circ}$ to $24^{\circ} 2 \theta$, where the scans were run before and after the samples had undergone a glycolation treatment (see "Lithostratigraphy" in the "Methods" chapter [Jaeger et al., 2014a]). This treatment was used to determine the presence of expandable clay minerals (e.g., smectite). The scans show no indication of expandable clay minerals in the cores until $\sim 800 \mathrm{~m}$ CCSF-B. On the last sample, we observed a shoulder at $\sim 7^{\circ} 2 \theta$ in the whole samples. After the treatment, a small peak was observed at $\sim 5^{\circ} 2 \theta$, suggesting the presence of expandable clay minerals. Additional minor mineralogical phases documented in the bulk mineralogy of the cores include calcite associated with well-indurated siltstone intervals and pyrite associated with localized structures such as burrows. Our preliminary findings are similar to the results of Molnia and Hein (1982) from samples collected on the continental shelf of the Gulf of Alaska.

\section{Lithostratigraphy and depositional interpretations}

Figure F12 shows the distribution of observed primary sedimentary lithologies and characteristics and how they relate to unit boundaries and core recovery at Site U1418. Unit I is characterized by the high abundance of interbedded mud and silt and sand beds. Although a minor constituent, the highest abundance of diatom ooze and diatom-rich mud lithofacies observed at Site U1418 was between 100 and $175 \mathrm{~m}$ CCSF-B. The number of clasts per meter, which was only recorded within this unit because they become too abundant to individually count in deeper units, increases toward the top of Unit I, culminates at $125 \mathrm{~m}$ CCSF-B, and then declines toward the top of the sequence. Relative to the underlying units, we also observe a higher number of volcanic ash layers and increased occurrences of volcaniclastic-bearing sand and mud. Subunit IIA is defined by the abrupt appearance of diamict and mud with vari- able clast abundance and the disappearance of the interbedded mud and silt and sand layers observed in Unit I (Fig. F12). Subunit IIB is characterized by the alternation of mud with clasts, laminations, and mud. The mud between 525 and 625 m CCSF-B exhibits bioturbation intensity index values of 3 , and at a finer (meter level) observational scale, these bioturbated intervals are found between laminated mud and/or mud with clasts. The abrupt appearance of diamict interbedded with units of laminated mud typifies Subunit IIC. The Matuyama/Brunhes boundary, which marks the transition between the early and Middle Pleistocene (0.781 Ma), was identified within the upper portion of Subunit IIC (see "Paleomagnetism"). Subunit IID consists of alternation of mud with clasts, mud with laminations, and mud with extensive bioturbation and overall has a similar appearance to Subunit IIB (Fig. F12). The abrupt downcore appearance of interbedded mud and silt at $\sim 800 \mathrm{~m}$ CCSF-B, in conjunction with mud with laminations and mud with clasts, characterizes Unit III. Volcanic ash is present near the top of the unit, and clast-rich diamict beds are found near the base at $\sim 900 \mathrm{~m}$ CCSF-B. The top of Unit IV is at $920 \mathrm{~m}$ CCSF-B and is typified by a mixture of gray to dark gray (N 3 to N 4) mud and clast-rich muddy diamict with soft-sediment deformation and intrastratal contortions. Bioturbated and laminated mud are notably absent from this unit. We compared the lithologic characteristics described above with physical properties data collected by the onboard core logging systems but did not encounter consistent associations between natural gamma radiation (NGR) and abs $\left(\mathrm{a}^{*} / \mathrm{b}^{*}\right)$ and the sedimentary components as we did at Site U1417 (see "Lithostratigraphy" in the "Site U1417" chapter [Jaeger et al., 2014b]). We do, however, see some association between the distribution of lithostratigraphic units and changes in magnetic susceptibility where peaks in clast abundance in Unit I are coincident with peaks in magnetic susceptibility, and these associations are described in more detail in "Core-log-seismic integration."

\section{Unit I}

Lithostratigraphic Unit I consists mainly of dark gray (N 4) mud with thin silt beds (Fig. F9D). We interpret most of the mud in Unit I as originating from suspension settling through the water column and mud-rich sediment gravity flows. The thin silt beds are interpreted to represent frequent and regular deposition from silt-rich sediment gravity flows in the overbank environments of the proximal Surveyor Fan system. The documentation of thin sand beds with normal grading and erosive bases (Facies F3b on Table T2), although uncommon, suggests that peri- 
odically more tractive, higher velocity currents reached the overbank environments. Subaqueous sediment gravity flows could have been generated from the continental shelf/slope by many episodic processes that likely include seasonal fluctuations at the glacier terminus, earthquakes, high sedimentation rates that created slope oversteepening, waveinduced liquefaction, and iceberg calving (Powell and Molnia, 1989). The lonestones in Unit I are interpreted to be ice-rafted debris mostly deposited by icebergs calved from tidewater glaciers and/or from sea ice. The diatom intervals in Unit I might be related to one or several processes:

- Increased biological productivity in the water column in the vicinity of sea ice margins (Sakshaug, 2004; Smith et al., 1987);

- Increased biological productivity due to optimized oceanographic conditions (e.g., reduced sea ice cover, surface layer overturning, and/or mixing by gyres);

- Enhanced macro (N, P) and/or micro (Fe) nutrient supply from land (volcanic ash, dust, etc.) leading to increased biological productivity (Hamme et al., 2010);

- Seawater silica saturation, leading to a higher diatom productivity and preservation (e.g., Brzezinski et al., 1998; Dugdale et al., 1995); and

- Decreased input of terrigenous sediments (i.e., less dilution).

The sources for lonestones documented in Unit I are interpreted to be the onshore St. Elias Mountains, Chugach Mountains, and coastal ranges located along the southern coast of Alaska and northwestern British Columbia, Canada. Metasedimentary rocks, common lithologies in the lonestones, occur in all these ranges (Plafker, 1987; Plafker et al., 1994; Gasser et al., 2011), but the combination of metagabbro, quartzite, rhyolite, and limestone suggest that the rocks of the Alexander Terrane (Gehrels and Saleeby, 1987; Gehrels and Berg, 1994) may be considered as a possible source for some of the ice-rafted debris. Felsic igneous clasts may be derived from the SanakBaranoff plutons found dispersed along the southern Alaska margin (Sisson et al., 2003). A previous study of lonestones collected from fjords along the coast of Alaska found these lithologies and interpreted the Alexander Terrane as a probable source (Cowan et al., 2006). The rare volcanic ash and volcaniclasticbearing sand at Site U1418 indicates that the location was proximal enough to either the Aleutian or Wrangell volcanic belts to have periodic influxes of pyroclastic detritus.

\section{Unit II}

The strong influence of icebergs (and/or sea ice) on the deposition of facies within Unit II is indicated by the presence of ice-rafted debris in the form of lonestones deposited in massive or laminated mud, as well as the accumulation of diamict. Subunits IIA and IIC are both identified by the presence of massive clast-poor muddy diamict with pebbles, granules, and coarse sand scattered throughout. Laminae are present but rare within the interbedded mud and diamict. Subunit IIA is similar to Subunit IIC: a regular pattern of massive diamict grades into laminated to very thin bedded mud. The 13 diamict beds in Subunit IIC range in thickness from 30 to $150 \mathrm{~cm}$. These thick diamict beds appear to indicate periods of more intense iceberg rafting. Most are associated with moderate to occasionally heavy bioturbation, which may suggest a slower sediment accumulation rate than in the laminated mud intervals. Further, the addition of micronutrients (associated with the terrestrial sediments) may have stimulated marine productivity. Periods with higher marine productivity are indicated by diatom ooze that occurs in Core 341-U1418F-46R within Subunit IIC.

The diamict beds within Subunits IIB and IID are more variable in thickness and composition. Most commonly they are thin and interbedded with laminated mud or mud with dispersed clasts. Interbedded mud with diamict facies occurs commonly within these subunits and is characterized by several-centimeter-thick diamict that is composed of granules and coarse sand but notably lacking in lonestones (Fig. F9H). These thin, bedded diamict intervals are bounded by thinly laminated packages of mud that appear to be aggradational. This lithology is similar to gravelly mud beds and laminated mud described from Southeast Alaskan glacial fjords (Cowan et al., 1999) that was deposited by sea ice rafting and turbid meltwater plumes. In the modern glacimarine setting of Alaska (restricted to bays and fjords), sea ice forms in winter from freezing of freshwater at the sea surface and debris is entrained along beaches and fan deltas as ice is stranded along the shore by tidal variations. During the summer, meltwater plumes deposit laminated mud (Cowan et al., 1999). The silt-mud couplets, termed cyclopels, form by suspension settling that is influenced by variations in meltwater stream discharges, wind-generated waves and currents, and tidal fluctuations (Powell and Molnia, 1989). The thin diamict beds at Site U1418 may record the presence of sea ice during glacial periods; however, further multiproxy studies are needed to verify the presence of sea ice. Although sea ice is not 
present in this region today, studies of diatoms and dinocysts indicate that it was widespread during colder periods such as the Younger Dryas and Last Glacial Maximum (Barron et al., 2009; de Vernal and Pedersen, 1997).

\section{Unit III}

Unit III is similar to Unit II, with massive/bioturbated mud occasionally interbedded with laminated mud. The diagnostic characteristics of Unit III relative to Unit II are the introduction of siltstone and sandstone beds, two thin clast-abundant muddy diamicts beds with rip-up clasts, a decrease in lonestone occurrence, and an overall decrease in diamict beds. The well-sorted, thin silt/sand beds at the top of this unit have sharp bases and are interpreted as distal sediment gravity flow. Clast-rich diamicts at the base of the unit are interpreted as sediment gravity flows. Despite the decrease in the number of lonestones and diamict beds relative to Unit II, their presence in this unit indicates that glacially derived and transported sediment was an important contributor during deposition. The cycles of interbedded massive and bioturbated mud (with dispersed clasts and few diamict beds) and laminated mud may point to periods characterized by a weaker glacimarine signal that alternate with periods of more intense ice rafting.

\section{Unit IV}

The mixture of gray to dark gray ( $\mathrm{N} 3$ to $\mathrm{N} 4)$ mud and clast-rich muddy diamict characterized by softsediment deformation and intrastratal contortions of Unit IV are interpreted as the products of one or more mass transport events, which were interpreted from seismic reflection data (see "Background and objectives;" Reece et al., submitted). The range of soft-sediment deformational fabrics suggests that some of the beds were partially lithified before being transported and redeposited at Site U1418. The large amount of fine-grained matrix with flow textures surrounding angular blocks in this deposit suggests that large amounts of fluid or slurry were available during transport and redeposition of the failed sediments. The timing of the mass transport event appears to be at $\sim 1.2 \mathrm{Ma}$ based on our current understanding of the age model for this site (see "Stratigraphic correlation" and "Paleomagnetism").

\section{Paleontology and biostratigraphy}

The abundances of microfossils at Site U1418 can be divided into two distinct depth intervals. The upper
$200 \mathrm{~m}$ CCSF-B is rich in both siliceous and calcareous microfossils. Within this sediment interval, preservation is often moderate to good for planktonic and benthic foraminifers, diatoms, and radiolarians, with abundance fluctuations from barren to abundant. Deeper than 200 m CCSF-B, numerous intervals are barren of siliceous microfossils but calcareous microfossils are more consistently observed (Fig. F15). The biostratigraphic age model of Site U1418 was established by combining diatom, planktonic foraminifer, and radiolarian datums (Table T5). The oldest datum encountered is the last occurrence (LO) of the planktonic foraminifer Neogloboquadrina inglei, which suggests that the sediments around $600 \mathrm{~m}$ CCSF-B are older than 0.7 Ma. Beyond the biostratigraphic schemes, the micropaleontologic assemblages may provide a record of climatic shifts. We recognize downcore variation in the relative abundances of environmentally sensitive planktonic foraminifers and radiolarians that suggest periods of warming and cooling (Fig. F16). In addition, variation in the diatom assemblages may indicate changes in paleoprimary productivity, sediment transport from coastal areas, and the influence of sea ice (Figs. F17, F18). Changes in the benthic foraminiferal faunas may suggest variation in benthic oxygenation (Fig. F18).

\section{Diatoms}

In order to define the sediment age and paleoenvironmental conditions, core catcher samples and samples from selected split core sections from Holes U1418A-U1418F were analyzed (Table T6). For a detailed description of diatom zonal scheme and taxonomy, see the "Methods" chapter (Jaeger et al., 2014a).

The sampling resolution for each of the studied holes is $\sim 3$ samples per core; however, 431 of the 573 samples investigated are barren of diatoms (Fig. F15; Table T6). Diatom occurrence and valve preservation vary strongly throughout the sediment column of Site U1418. Diatoms occur more frequently at depths shallower than $190 \mathrm{~m}$ CCSF-B and only sporadically at greater depths.

\section{Diatom biostratigraphy}

We recognize the bioevent LO of Proboscia curvirostris (Jousé) Jordan et Priddle (D120; $0.3 \pm 0.1 \mathrm{Ma}$ ) between Samples 341-U1418F-11R-2W, $100 \mathrm{~cm}$, and $4 \mathrm{R}-2 \mathrm{~W}, 100 \mathrm{~cm}$ (Table T5), marking the base of Zone NPD 12 (present-[0.3 \pm 0.1$] \mathrm{Ma}$ ). The LO datum of Actinocyclus oculatus Jousé (D110; $1.1 \pm 0.1 \mathrm{Ma}$ ) is not observed; therefore, sediments deeper than the LO of P. curvirostris are within Zone NPD $11([0.3 \pm 0.1]-$ [1.1 \pm 0.1$] \mathrm{Ma}$ ). 


\section{Diatom paleoenvironmental considerations}

Valve preservation ranges from good to poor and tends to be better whenever abundance is higher (Fig. F15). Strong variations in abundance and preservation and shifts in the species composition of the diatom assemblage can be used to reconstruct paleoceanographic changes in the pelagic and coastal regions of the Gulf of Alaska.

Independent of the downcore depth, the diatom community of Site U1418 is diverse and mainly consists of Pleistocene to Holocene species typical of cold-temperate, high-latitude ocean waters.

Cold-water species, including Neodenticula seminae (Simonsen et Kanaya) Akiba et Yanagisawa, Actynocyclus curvatulus Janisch in Schmidt, and Rhizosolenia hebetata f. hiemalis Gran (Sancetta, 1982; Medlin and Priddle, 1990; Koizumi 2008), tend to dominate whenever total diatom abundance is greater than "few" (Table T6; Fig. F16). Warm- and temperate-water species are always less abundant than cold-water species (Figs. F16, F18). Main contributors to the warm and temperate group include Rhizosolenia hebetata f. semispina (Hensen) Gran, Stephanopyxis spp., and Bacterosira spp. (Hasle and Syvertsen, 1996; Koizumi, 2008).

The influence of coastal waters on Site U1418 is suggested by the recurrent presence of coastal and benthic diatoms; the resting spores of Chaetoceros, Thalassionema nitzschioides var. nitzschioides (Grunow) Mereschkowsky; and the tycoplanktonic diatom Paralia spp. (Hasle and Syvertsen, 1996). The common occurrence of Chaetoceros resting spores at sediment depths shallower than $200 \mathrm{~m}$ CCSF-B is indicative of transport of highly productive coastal waters into the pelagic realm of the Gulf of Alaska. The relative abundance of Chaetoceros resting spores is greater whenever the total diatom abundance is greater than "few." The sporadic presence of Paralia spp. and some other tycoplanktonic/benthic diatoms (mainly Achnanthes spp., Cocconeis spp., and Odontella aurita [Lyngbye] Agardh) at Site U1418 (shown as coastal and neritic diatoms in Fig. F17) likely reflects input of coastal and neritic sediment into the pelagic realm of the Gulf of Alaska. Rare occurrences of the sea ice-related species Bacterosira bathyomphala (P.T. Cleve) Syvertsen et Hasle, Fragilariopsis cilyndrus (Grunow) Frenguelli, and Thalassiosira gravida Cleve (Armand et al., 2005; Koizumi, 2008) are mainly observed between 50 and $80 \mathrm{~m}$ CCSF-B and between 100 and 195 m CCSF-B (Fig. F18).

\section{Radiolarians}

A total of 179 samples in Holes U1418A-U1418F were prepared for radiolarian analyses (Table T7). Radiolarian preservation is generally good, and abundances range from few to abundant in Holes U1418A-U1418E, with few barren intervals (Fig. F15). However, in Hole U1418F, we observe long intervals (from 500 to $950 \mathrm{~m}$ CCSF-B) where radiolarians do not occur or are rare in abundance with poor preservation.

\section{Radiolarian biostratigraphy}

We encountered three radiolarian datums at Site U1418. We encountered only one radiolarian datum in Holes U1418A-U1418E (Fig. F15). We observe the LO of Lychnocanoma sakaii Morley and Nigrini between Samples 341-U1418D-9H-CC (75.21 m CCSFB) and 341-U1418A-7H-CC (62.15 m CCSF-B), giving an estimated age of $0.03 \pm 0.03 \mathrm{Ma}$ (Fig. F19; Table T5). The LO of Stylacontharium acquilonium (Hays) $(0.4 \pm 0.1 \mathrm{Ma})$ is not observed in Holes U1418AU1418E, suggesting that the collected sediment from those holes is younger than $0.4 \pm 0.1 \mathrm{Ma}$ and is located within the radiolarian Botryostrobus acquilonaris Zone $(0-0.5 \mathrm{Ma})$. The LO of $S$. acquilonium is recorded between Samples 314-U1418F-17R-CC (414.65 m CCSF-B) and 11R-CC (354.82 m CCSF-B) (Fig. F19; Table T5). The LO of Stylatractus universus Hays $(0.5 \pm 0.1 \mathrm{Ma})$, which defines the top of the radiolarian $S$. universus Zone $(0.5-1.3 \mathrm{Ma})$, is also encountered in Hole U1418F between Samples 341U1418F-27R-CC (509.83 m CCSF-B) and 18R-CC (424.13 m CCSF-B) (Fig. F19; Table T5).

\section{Radiolarian paleoenvironmental considerations}

Radiolarians are grouped according to their environmental preferences following Kamikuri et al. (2008). Cold-water species, such as Stylodictya validispina and Stylochlamydium venustum, dominate the assemblages (Fig. F16; Table T7). Cycladophora davisiana, an intermediate-water dweller, frequently occurs at depths shallower than 250 m CCSF-B (Fig. F14). We also record the presence of subtropical fauna, including several species of the polyniids group (Gupta and Fernandes, 1997; Gupta, 2002) and Spongaster tetras irregularis. The abundances of each group oscillate downcore. Cold-water species are abundant from 0 to $180 \mathrm{~m}$ CCSF-B (Fig. F16). Warm-temperate species occur infrequently; however, when present, their abundances are high from 0 to $180 \mathrm{~m}$ CCSF-B (Fig. F16). Variations of cold- and warm-water species 
probably suggest glacial-interglacial climate changes. An abundance peak of $L$. sakaii near $120 \mathrm{~m}$ CCSF-B suggests that the sediment age is $\sim 60 \mathrm{ka}$ at this depth (Matul et al., 2002). Deeper than $200 \mathrm{~m}$ CCSF-B, radiolarians are only occasionally observed (Fig. F15), but when present, several sporadic abundance peaks of cold-water radiolarian species are recorded (Fig. F16). Deeper than 500 m CCSF-B, all of the studied intervals are barren of radiolarians, which suggests high dissolution of siliceous microfossils.

\section{Foraminifers}

Core catcher samples from Holes U1418A-U1418D and U1418F were examined for planktonic foraminifers from the $>125 \mu \mathrm{m}$ size fraction in 72 samples (Table T8) and for benthic foraminifers from the $>63$ $\mu \mathrm{m}$ size fraction in 84 samples (Table T9). Some samples, especially those taken deeper than $\sim 700 \mathrm{~m}$ CCSF-B, were difficult to disaggregate and could not be investigated.

\section{Planktonic foraminifers}

Within 72 samples, we observed 12 planktonic foraminifer species at Site U1418. Planktonic foraminifers are present in all examined core catcher samples, with abundances ranging from present to dominant. Their preservation ranges from moderate to very good (Fig. F15; Table T8). Neogloboquadrina pachyderma (sinistral) dominates in the planktonic foraminiferal assemblage, followed by Globigerina umbilicata and Globigerina bulloides.

The planktonic foraminiferal faunal assemblage at Site U1418 shows cyclic changes, as seen in the relative abundances of G. bulloides and G. umbilicata (Fig. F16). Because these species have a preference for relatively warm water compared to the preferences of $N$. pachyderma in the modern North Pacific (e.g., Asahi and Takahashi, 2007; Kuroyanagi et al., 2008; Sautter and Thunnell, 1989), the cyclic changes in their relative abundances likely indicate temperature changes associated with glacial-interglacial intervals.

$N$. inglei was observed from Sample 341-U1418F-64RCC (863.39 $\mathrm{m} \mathrm{CCSF-B)}$ to its $\mathrm{LO}(0.7 \pm 0.1 \mathrm{Ma}$; Kucera and Kennett, 2000) in Sample 40R-CC (638.32 m CCSF-B) (Tables T5, T8; Fig. F17). The presence of $N$. inglei in Sample 341-U1418F-21R-CC (454.01 m CCSF-B) is interpreted as being reworked. This reworking hypothesis is also supported by the presence of Neoglolobigerina kagaensis (LO $2.0 \pm 0.1$ Ma; Kennet et al., 2000) (Fig. F17) and is consistent with the presence of neritic and coastal diatoms and Chaetoceros resting spores, which indicate occasional sedimentary inputs from the shelf margin to Site U1418.

\section{Benthic foraminifers}

Of the 84 samples that were examined at Site U1418, 79 contained benthic foraminifers with abundances ranging from present to abundant (Table T9). Preservation ranged from poor to very good with $\sim 38 \%$ of samples judged as poorly preserved (Fig. F15). Fifty species or species groups were identified. Median assemblage diversity was 6 genera per sample with a maximum of 21 genera per sample (not sample-size standardized). The number of genera per sample has a generally recurring pattern through time, suggestive of glacial-interglacial intervals, which may partially reflect variations in preservation quality and abundance (Fig. F16).

The majority of assemblages are characterized by dominant to abundant Cassidulina cushmani and/or Nonionella labradorica. Elphidium spp. is also frequently encountered and is abundant to dominant in some samples. C. cushmani is most abundant at middle to lower bathyal water depths $(\sim 500-2000$ $\mathrm{m})$, and $N$. labradorica increases in abundance deeper than $1500 \mathrm{~m}$ water depth in the Gulf of Alaska (Bergen and O'Neil, 1979). A majority of Elphidium spp. specimens are similar to Elphidium sp. B in Keller (1980), which is described as an upper middle bathyal species (500-1500 m). Occasionally, Stainforthia spp. is dominant and, along with increased abundances in other elongate buliminids (Fig. F18), may indicate periodic low-oxygen conditions at the seafloor. Melonis pompilioides, Pullenia bulloides, Globobulimina auriculata, Cibicides spp., and a small lowtrochospiral species tentatively identified as Alabaminella weddellensis are also characteristic of assemblages at Site U1418.

Some species more typical of shelf settings, including Cassidulina teretis, Karreriella baccata, and Elphidium excavatum, are occasionally observed and may have been transported to the site. However, the tests of $E$. excavatum are very irregular and appear to have developmental abnormalities, which may suggest they were living in suboptimal conditions (i.e., deep water).

\section{Other microfossils}

\section{Ostracods}

Seven samples examined for benthic foraminifers contained ostracod valves (see comments in Table T9). 


\section{Calcareous nannofossils}

Calcareous nannofossils are present in isolated intervals in the upper $\sim 600 \mathrm{~m}$ CCSF-B of Site U1418. Samples deeper than $600 \mathrm{~m}$ CCSF-B were not analyzed. When present, preservation varies from poor to good and abundance varies from very rare to few. The species present include Coccolithus pelagicus, Cruciplacolithus neohelis, Dictyococcites productus, Emiliania huxleyi, Gephyrocapsa muellerae, and other reticulofenestrids.

\section{Summary}

Based on the downcore occurrence of microfossils at Site U1418, two distinct intervals were identified. A rich siliceous and calcareous community is observed at depths shallower than $200 \mathrm{~m}$ CCSF-B. Deeper than $200 \mathrm{~m}$ CCSF-B, calcareous microfossils are consistently preserved, but numerous intervals are barren of siliceous microfossils (Fig. F15). The rare occurrence of diatoms and radiolarians deeper than $200 \mathrm{~m}$ CCSF-B impedes identification of reliable biostratigraphic datums. The oldest datum encountered is the LO of the planktonic foraminifer $N$. inglei, which suggests that sediments around $600 \mathrm{~m}$ CCSF-B are older than 0.7 Ma. This age-depth tie point agrees with the Matuyama/Brunhes polarity reversal observed at $260 \mathrm{~m}$ CCSF-B (Fig. F20).

Strong variations in environmentally sensitive planktonic foraminifers and radiolarians record the alternation of warming and cooling intervals (Fig. F16). In addition, variations in bottom water oxygenation are suggested by species changes in the benthic foraminiferal fauna (Fig. F17). Variations in diatom abundance and changes in species composition indicate changes in paleoproductivity, transport from shallow coastal waters, and a period of sea ice influence over Site U1418 (Fig. F17).

\section{Stratigraphic correlation}

The composite depth scale at Site U1418 was constructed from 0.0 to $941.44 \mathrm{~m}$ core composite depth below seafloor (CCSF-A). The splice consists of one complete and continuous interval from the mudline to $271.40 \mathrm{~m}$ core composite depth below seafloor (CCSF-D). The CCSF-A and CCSF-D depth scales are defined in "Stratigraphic correlation" in the "Methods" chapter (Jaeger et al., 2014a).

The splice ranges from the top of Core 341-U1418C$1 \mathrm{H}$ (the mudline) to the base of Core 341-U1418D26H (Tables T10, T11). To the extent possible, the splice was constructed from Holes U1418C and U1418D because Hole U1418A was sampled at sea and Hole U1418B consisted of two special-purpose cores for pore water sampling. It was necessary to include four short intervals of Hole U1418A in the splice. Hole U1418E was spot cored to cover specific gaps in the composite depths and was used for three intervals in the splice. Hole U1418F consists of rotary drill cores at depths deeper than those included in the splice.

Weather was calm and ship heave was negligible during coring at Site U1418; thus, weather did not contribute core-to-core variability to the affine growth curve. Nevertheless, many of the APC cores contain evidence for stretched or compressed intervals relative to equivalent depths in other holes; we interpret these discrepancies as piston effects from coring. In support of this hypothesis, we observed that the drill string bounced on the order of $1 \mathrm{~m}$ during some APC shots (recorded as variations in heave compensator position and wireline tension), implying that the piston was not always stationary during penetration of the core barrel. Such decoupled variations in motions of the piston and the core barrel could result in decimeter- to meter-scale compression ("plowing" effects) or expansion ("suction" effects) within cores. We also observed instances of significant flow-in, generally near the base of cores (for example, Core 341-U1418-32H is mostly flowin). Flow-in is often associated with failure of the core barrel to fully stroke, for example, because of incomplete penetration of a relatively stiff formation. The resulting suction during core pull out creates flow-in. For the splice, when multiple copies of specific sediment sequences were available, we avoided apparent stretched or compressed intervals and excluded intervals of flow-in.

Correlations between holes were accomplished using the Integrated Ocean Drilling Program (IODP) Correlator software (version 1.695), and all splice tie points were checked with digital line-scan images with Corelyzer (version 2.0.2), linked to Correlator. During coring, real-time development of composite depths and guidance for coring operations relied on Special Task Multisensor Logger (STMSL) gamma ray attenuation (GRA) bulk density and magnetic susceptibility data. The final composite depth scale (CCSF-A) and the splice (CCSF-D scale) are based primarily on the stratigraphic correlation of magnetic susceptibility and GRA density from the WholeRound Multisensor Logger (WRMSL) (Figs. F21, F22) and verified with whole-round NGR and reflectance spectroscopy color data from the Section Half Multisensor Logger (SHMSL). Anomalously low GRA density from the WRMSL was also used as an indicator of core disturbance.

The CCSF-A and CCSF-D scales were constructed by assuming that the uppermost sediment (the mud- 
line) in Core 341-U1418C-1H represented the sediment/water interface. This assumption was supported by the presence of an $\sim 6 \mathrm{~cm}$ thick layer of brownish sediment at the core top. An approximate mudline was also recovered in Cores 341-U1418A-1H and $341-\mathrm{U} 1418 \mathrm{~B}-1 \mathrm{H}$, which confirms the fidelity of the top of the recovered interval. Core 341-U1418C$1 \mathrm{H}$ serves as the "anchor" in the composite depth scale and is the only core with depths that are the same on the CCSF-A and CCSF-D scales. From this anchor we worked downhole, matching variations in core logging data between holes on a core-by-core basis using Correlator.

In the splice, a few tie points are tentative. In particular, the tie points between 341-U1418A-11H-6, $99.91 \mathrm{~cm}$, and 341-U1418C-15H-1, $35.14 \mathrm{~cm}(109.95$ $\mathrm{m}$ CCSF-A), and between 341-U1418E-6H-6, 124.35 $\mathrm{cm}$, and 341-U1418D-14H-1, $66.47 \mathrm{~cm}(131.81 \mathrm{~m}$ CCSF-A), are supported by little core overlap, include potentially disturbed sediment in Section 1 of the deeper cores, and should be used cautiously. The tie point between 341-U1418C-31H-5, $23.52 \mathrm{~cm}$, and 341-U1418D-26H-1, $73.81 \mathrm{~cm}$ (262.71 m CCSF-A), also includes a potentially disturbed Section 1 and is based on very subtle structures in magnetic susceptibility. This tie point seems supported by NGR and GRA density but is considered very uncertain because of disturbance.

Within the splice, the composite CCSF-A depth scale is (by definition) equivalent to the CCSF-D depth scale. Note that the CCSF-D scale rigorously applies only to the spliced interval. Intervals outside the splice, although available with CCSF-A composite depth assignments, should not be expected to correlate precisely with fine-scale details within the splice or with other holes because of normal variation in the relative spacing of features in the recovered intervals from different holes. Such apparent depth differences may reflect coring artifacts or finescale spatial variations in sediment accumulation and preservation at and below the seafloor.

The cumulative offset between the CSF-A depth scale and the CCSF-A or CCSF-D depth scales is nonlinear (Fig. F23). The affine growth factor (a measure of the fractional stretching of the composite section relative to the drilled interval; see "Stratigraphic correlation" in the "Methods" chapter (Jaeger et al., 2014a) is 1.121 on average (i.e., the sediment is expanded by $\sim 12 \%$ relative to the interval drilled) at Site U1418 in the APC-cored interval from 0 to $152.39 \mathrm{~m}$ CCSF-A or CCSF-D. Anomalies around this relatively uniform affine growth relationship are plausibly explained by imprecision of tide corrections on coring depths, potential distortion of cores by core-pipe rebound and piston effects, and fine- scale spatial variations in sediment accumulation and preservation at and below the seafloor.

Over the interval from 152.39 to 272.00 m CCSF-A, the affine growth factor is 1.20 (i.e., the sediment is expanded by $\sim 20 \%$ relative to the interval drilled). This high rate of expansion at Site U1418 does not appear to be an artifact introduced by the construction of the CCSF-A depth scale; for the most part the splices between holes were good in this interval. Rather, the high rate of expansion in this interval likely reflects either coring artifacts in the borehole or gas expansion of sediments during recovery (see "Geochemistry" for discussion of methane at this site). Deeper than $272.00 \mathrm{~m}$ CCSF-A, intervals of possible correlation were found between a few cores in the interval from $\sim 322$ to $\sim 336 \mathrm{~m}$ CCSF-A (Cores 341-U1418D-35X through 341-U1418F-4R and 341U1418D-36X through 341-U1418F-5R), but these intervals were not considered sufficiently continuous nor were the correlations certain enough to warrant core-by-core adjustment of their affine values. Thus, deeper than $272.00 \mathrm{~m}$ CCSF-A, the affine value is held constant at $42.09 \mathrm{~m}$. This value applies to APC, $\mathrm{XCB}$, and RCB cores in Hole U1418F. This does not imply a lack of sediment expansion deeper than $272.00 \mathrm{~m}$ CCSF-A, just that no constraint on its extent is available.

Calculation of mass accumulation rates based on the CCSF-A or CCSF-D scales must correct for the affine growth factor. To facilitate this process, we developed an additional depth model, CCSF-B, which compressed the CCSF-A and CCSF-D scales into a scale that has the same total depth of sediment column as the actual interval drilled (see "Stratigraphic correlation" in the "Methods" chapter (Jaeger et al., 2014a). This depth scale is approximately consistent with depths defined by borehole logging but was not correlated directly to the logs. The following three equations define transformation of the CCSF-A or CCSF-D depth scale into CCSF-B depths (Fig. F23):

From 0 to 152.39 m CCSF-A/CCSF-D:

$$
\text { CCSF-B }=0.87945 \times \text { CCSF-A/CCSF-D } .
$$

From 152.39 to 272.00 m CCSF-A/CCSF-D:

$$
\text { CCSF-B }=0.80173 \times \text { CCSF-A/CCSF-D + } 11.844 .
$$

For 272.00 m CCSF-A/CCSF-D:

$$
\text { CCSF-B = CCSF-A/CCSF-D - } 42.086 .
$$

The depth boundaries between these equations are chosen to coincide with splice points (341-U1418C$21 \mathrm{H}-6,92.0 \mathrm{~cm}$, tied to $341-\mathrm{U} 1418 \mathrm{D}-16 \mathrm{H}-1,90.1 \mathrm{~cm}$, 
at $152.39 \mathrm{~m}$ CCSF-A) and between Cores 341U1418D-26H (base at $271.40 \mathrm{~m}$ CCSF-A) and $27 \mathrm{H}$ (top at 272.09 m CCSF-A).

\section{Initial age model}

All available paleomagnetic and biostratigraphic age datums (Tables T5, T12) were integrated to construct minimum and maximum shipboard age models (Fig. F24; Table T13); together, these preliminary age models span most of the uncertainty in the shipboard datums. The age models were constructed in the CCSF-B depth scale but are also reported in the CCSF-A depth scale (Table T13). All paleomagnetic datums observed in Hole U1418F (Matuyama/Brunhes polarity reversal and the top and base of the Jaramillo Chron) are included in the shipboard minimum and maximum age models.

The shipboard minimum and maximum age models are calculated in increments of $0.2 \mathrm{~m}$.y. between 0 and 1.2 Ma. When averaged within these intervals, inferred sediment accumulation rates in the interval 0-0.2 Ma are 1041-1505 m/m.y. (Table T13; Fig. F25). Over the interval 0.2-1.2 Ma, sediment accumulation rates are on average $450-825 \mathrm{~m} / \mathrm{m}$.y., but uncertainty ranges between 345 and $1139 \mathrm{~m} / \mathrm{m}$.y. In Cores 341-U1418F-70R, 71R, and 72R, the sediment layering is disturbed, which is inferred to represent a MTD (see "Lithostratigraphy"). Extrapolation of the age models or sedimentation rates deeper than Core 341-U1418F-69R is thus unjustified.

\section{Geochemistry Interstitial water chemistry}

Interstitial water (IW) samples were taken in Holes U1418A, U1418B, U1418D, and U1418F at increasing depth ranges; sampling was designed to include an overlap in the sampled interval between each successive hole. The following results are expressed on the CCSF-B scale for Site U1418 (see "Stratigraphic correlation").

In Hole U1418A, 29 IW samples were taken with a resolution of two samples per core in Cores 341U1418A-1H and $2 \mathrm{H}$, three samples per core in Cores $3 \mathrm{H}$ and $4 \mathrm{H}$, two samples per core in Cores $5 \mathrm{H}$ and $6 \mathrm{H}$, and one sample per core from Core $7 \mathrm{H}$ to the bottom of the hole. Whole rounds for IW analysis were $5 \mathrm{~cm}$ long in Cores 341-U1418A-1H through $12 \mathrm{H}$ and $10 \mathrm{~cm}$ long in Cores $13 \mathrm{H}$ through $32 \mathrm{H}$. All samples from Hole U1418A were collected from APC cores (0-204.15 m CSF-A; 0-205.0 m CCSF-B). In Hole U1418B, six IW samples were taken from APC cores, with a resolution of three samples per core in Cores 341-U1418B-1H and $2 \mathrm{H}(5 \mathrm{~cm}$ long whole rounds). In Hole U1418D, 12 IW samples were taken from Cores 341-U1418D-22H through 36X (148.9$223.1 \mathrm{~m}$ CSF-A; $289.3 \mathrm{~m}$ CCSF-B) $(10 \mathrm{~cm}$ long whole rounds), with a more irregular sampling resolution than in Hole U1418A because of variable core recovery.

In Hole U1418F, 58 IW samples were taken from Cores 341-U1418F-4R through 65R (240.0-831.5 m CCSF-B). Hole U1418F was drilled using the RCB system, which has the potential for contamination of IW samples by surface seawater and drilling muds (e.g., Chambers and Cranston, 1991). However, successful recovery of uncontaminated RCB sequences for IW analysis has also been reported (e.g., Shipboard Scientific Party, 2000; Fulthorpe, Hoyanagi, Blum, and the Expedition 317 Scientists, 2011). The improved core recovery in Hole U1418F allowed IW sampling on complete whole rounds ranging in length from 9 to $19 \mathrm{~cm}$, and we did not identify evidence for contamination with seawater in the chemical analyses (see below). In cases of strongly fractured and/or indurated core material toward the bottom of Hole U1418F (deeper than Core 341U1418F-65R), no IW samples were taken. The compositions of IW samples taken from overlapping depths between the different holes were in good agreement, allowing for the construction of composite IW records.

The applied squeezing pressures ranged from 8,000 to $32,000 \mathrm{psi}$, and the volumes of IW recovered range between 12 and $40 \mathrm{~mL}$. Splits of the IW samples were taken and processed following methods outlined in "Geochemistry" in the "Methods" chapter (Jaeger et al., 2014a). IW samples were also preserved for shore-based analysis of dissolved trace metals, oxygen/sulfur/calcium/strontium isotopes, dissolved inorganic carbon, and silica.

\section{Alkalinity, pH, chloride, and salinity}

Following a steep increase in the uppermost $30.1 \mathrm{~m}$ CCSF-B, an alkalinity maximum $(31.8 \mathrm{mM})$ occurs at $76.1 \mathrm{~m}$ CCSF-B (Fig. F26A). Apart from a slight decrease around $93 \mathrm{~m}$ CCSF-B, alkalinity stays above 30 $\mathrm{mM}$ to $158.7 \mathrm{~m}$ CCSF-B and then decreases to 5.2 $\mathrm{mM}$ by $249.1 \mathrm{~m}$ CCSF-B. Deeper than this depth, alkalinity decreases more gradually and largely remains $<4$ mM. Deeper than 600 m CCSF-B, alkalinity remains $<1 \mathrm{mM}$.

The $\mathrm{pH}$ values at Site U1418 decrease from 7.5 to 7.2 between 1.5 and $8.4 \mathrm{~m}$ CCSF-B (Fig. F26B). Deeper than this depth, $\mathrm{pH}$ values steadily increase to 7.8 $\mathrm{mM}$ (322.3-602.0 m CCSF-B), followed by a more rapid increase in $\mathrm{pH}$ deeper than $602 \mathrm{~m}$ CCSF-B to values $\sim 8.6$ deeper than 774 m CCSF-B. 
Chloride (titrated) concentrations mostly range between 520 and $570 \mathrm{mM}$ at Site U1418 (Fig. F26J). The uppermost chloride maximum occurs at $23.6 \mathrm{~m}$ CCSF-B ( $>571 \mathrm{mM}$ ), followed by another peak at $50.9 \mathrm{~m}$ CCSF-B (>570 mM). Deeper than this depth, chloride concentrations range between 520 and 570 $\mathrm{mM}$, following an overall decreasing trend that is particularly pronounced from $500 \mathrm{~m}$ CCSF-B to the bottom of the hole.

A salinity maximum of 35 occurs at Site U1418 between 11.0 and $41.3 \mathrm{~m}$ CCSF-B (Fig. F26I), followed by a gradual downcore decrease to 30 at $390.1 \mathrm{~m}$ CCSF-B. Deeper than this depth, salinity remains near 30 to the bottom of the hole.

\section{Dissolved ammonium, phosphate, and silica}

In the uppermost $300 \mathrm{~m}$ CCSF-B of Site U1418, the dissolved ammonium profile broadly resembles that of alkalinity (Fig. F26D). Dissolved ammonium increases rapidly with depth in the upper $25 \mathrm{~m}$, from $0.17 \mathrm{mM}$ (1.3 m CCSF-B) to $1.83 \mathrm{mM}$ (27.5 m CCSFB). Ammonium concentrations stabilize at $\sim 2.0 \mathrm{mM}$ between 27.0 and $103.7 \mathrm{~m}$ CCSF-B and then increase to a maximum of $3.86 \mathrm{mM}$ at $158.7 \mathrm{~m}$ CCSF-B. Deeper than $158.7 \mathrm{~m}$ CCSF-B, ammonium decreases to $\sim 2.3 \mathrm{mM}$ (340.2 $\mathrm{m}$ CCSF-B) and then decreases abruptly to $\sim 1.8 \mathrm{mM}$ between 400 and $448 \mathrm{~m}$ CCSFB. Following a final increase in dissolved ammonium between 480 and $550 \mathrm{~m}$ CCSF-B (to $\sim 2.2 \mathrm{mM}$ ), concentrations decrease downcore to $\sim 700 \mathrm{~m}$ CCSF-B, where ammonium concentrations of $\sim 0.9 \mathrm{mM}$ are recorded.

Phosphate concentrations fluctuate between 3.7 and $45.4 \mu \mathrm{M}$ in the upper $180 \mathrm{~m}$ CCSF-B at Site U1418 (Fig. F27J). Maxima in phosphate concentrations are recorded at 2.6, 30.1, 76.1, and $158.7 \mathrm{~m}$ CCSF-B. Phosphate concentrations decrease abruptly to 6.1 $\mu \mathrm{M}$ at $175.5 \mathrm{~m}$ CCSF-B and then remain low (0.5-5.0 $\mu \mathrm{M})$ and show a gradual decrease to the bottom of the hole.

Silica concentrations have considerable variability, superimposed upon an overall downcore decrease, which occurs in several steps (Fig. F26H). In the upper $175 \mathrm{~m}$ CCSF-B, silica concentrations fluctuate between 540 and $885 \mu \mathrm{M}$. From 175 to $618 \mathrm{~m}$ CCSF-B, the variability increases $(440-800 \mu \mathrm{M})$ and mean concentrations are lower. Deeper than 700 m CCSF$\mathrm{B}$, silica remains low $(100-400 \mu \mathrm{M})$.

\section{Dissolved sulfate, calcium, magnesium, potassium, sodium and bromide}

Sulfate concentrations decrease continuously over the uppermost $75 \mathrm{~m}$ at Site U1418, from $31.24 \mathrm{mM}$ (1.3 m CCSF-B) to $1.34 \mathrm{mM}$ (76.1 m CCSF-B) (Fig.
F26C), which is defined as the depth of total sulfate depletion. Deeper sulfate concentrations range between the detection limit and $3 \mathrm{mM}$.

Calcium concentrations vary between 10 and $13 \mathrm{mM}$ in the uppermost $65 \mathrm{~m}$ CCSF-B. A local calcium minimum is reached between 76.0 and $93.0 \mathrm{~m} \mathrm{CCSF-B}$ $(\sim 7.4 \mathrm{mM})$, followed by a continuous downcore increase to $\sim 20.3 \mathrm{mM}$ by $424.5 \mathrm{~m}$ CCSF-B (Fig. F27A). Calcium concentrations show a local minimum at $474.5 \mathrm{~m}$ CCSF-B $(17.7 \mathrm{mM})$ and then increase downcore, reaching $45-60 \mathrm{mM}$ by $\sim 800 \mathrm{~m}$ CCSF-B.

Magnesium concentrations vary between 50 and 65 $\mathrm{mM}$ in the uppermost $93.0 \mathrm{~m}$ CCSF-B (Fig. F27C). Deeper than $93.0 \mathrm{~m}$ CCSF-B, magnesium values decrease and reach a local minimum of $24.4 \mathrm{mM}$ around $448.4 \mathrm{~m}$ CCSF-B. Magnesium concentrations show a broad local maximum between 500 and 600 $\mathrm{m}$ CCSF-B (up to $24.0 \mathrm{mM}$ ) and then decrease to a minimum of $5.6 \mathrm{mM}$ at $802.5 \mathrm{~m} \mathrm{CCSF-B}$.

Potassium concentrations drop from 12.5 to $7.7 \mathrm{mM}$ between 1.3 and 27.5 m CCSF-B (Fig. F27B). A more gradual decrease follows, reaching a minimum of 2.1 $\mathrm{mM}$ by $434.3 \mathrm{~m}$ CCSF-B, interrupted by a local maximum around $150 \mathrm{~m}$ CCSF-B. Deeper than this depth, potassium concentrations continue to decrease, reaching values around $1 \mathrm{mM}$ at the bottom of the hole.

Sodium concentrations are $555 \mathrm{mM}$ around $23.6 \mathrm{~m}$ CCSF-B and remain above $500 \mathrm{mM}$ to $48.2 \mathrm{~m}$ CCSF-B (Fig. F26K). Deeper than this depth, sodium concentrations range from 432 to $485 \mathrm{mM}$ to $200 \mathrm{~m}$ CCSFB. A gradual increase in sodium concentrations occurs between 200 and $500 \mathrm{~m}$ CCSF-B, followed by a decrease to $\sim 400 \mathrm{mM}$ at the bottom of the hole.

Bromide concentrations are $1.2 \mathrm{mM}$ around $23.6 \mathrm{~m}$ CCSF-B to $48.2 \mathrm{~m}$ CCSF-B (Fig. F26E). Deeper than this depth, bromide concentrations show a downcore increase to $\sim 600 \mathrm{~m}$ CCSF-B, followed by a decrease to the bottom of the hole.

\section{Dissolved manganese, iron, barium, strontium, boron, and lithium}

Manganese concentrations at Site U1418 are highest in the two uppermost samples (117.1 and $83.8 \mu \mathrm{M}$ at 1.3 and $2.6 \mathrm{~m}$ CCSF-B, respectively), decrease rapidly to $4.8 \mu \mathrm{M}$ by $21.3 \mathrm{CCSF}-\mathrm{B}$, and stay $<15 \mu \mathrm{M}$ for most of the record to the bottom of the hole (Fig. F27I).

Iron concentrations are highest in the uppermost 30 $\mathrm{m}$ CCSF-B, reaching maximum values of 98.6 and $61.9 \mu \mathrm{M}$ at 8.4 and 27.4 m CCSF-B, respectively (Fig. F27H). Deeper than $30 \mathrm{~m}$ CCSF-B, iron concentrations stay $<6 \mu \mathrm{M}$, apart from elevated values (7.3$16.6 \mu \mathrm{M}$ ) between 122.0 and $149.8 \mathrm{~m}$ CCSF-B. 
Barium concentrations are below detection limit in the uppermost $66.3 \mathrm{~m}$ CCSF-B at Site U1418 (Fig. F27F). At $76.1 \mathrm{~m}$ CCSF-B, barium concentrations increase rapidly downcore, with a number of distinct local maxima between 60 and $120 \mu \mathrm{M}$. Deeper than $424.4 \mathrm{~m}$ CCSF-B, barium increases continuously to $137.3 \mu \mathrm{M}$ at $581.0 \mathrm{~m}$ CCSF-B and then decreases to $24.8 \mu \mathrm{M}$ by $802.5 \mathrm{~m}$ CCSF-B. Detectable barium concentrations are limited to the sediment interval with lowest sulfate concentrations.

Strontium concentrations follow a distinct alternating pattern in the upper $200 \mathrm{~m}$ CCSF-B of Site U1418 (Fig. F27G). Following a steep increase from $89.8 \mu \mathrm{M}$ at the core top to $107.7 \mu \mathrm{M}$ at $18.5 \mathrm{~m}$ CCSF-B, strontium gradually decreases to a minimum of $92.7 \mu \mathrm{M}$ at $57.4 \mathrm{~m}$ CCSF-B. A second local maximum of 129.3 $\mu \mathrm{M}$ is reached at $93.1 \mathrm{~m}$ CCSF-B, followed by a local minimum of $115.5 \mu \mathrm{M}$ at $122.0 \mathrm{~m}$ CCSF-B. The third local maximum of $145.0 \mu \mathrm{M}$ is reached at $175.5 \mathrm{~m}$ CCSF-B. Farther downcore, strontium gradually increases to values around $200 \mu \mathrm{M}$ by $\sim 650 \mathrm{~m}$ CCSF-B and then shows a minor decrease to the bottom of the hole.

The boron depth profile contains a number of distinct and abrupt changes (Fig. F27E). From $423 \mu \mathrm{M}$ at the core top, boron increases to $537 \mu \mathrm{M}$ at $32.6 \mathrm{~m}$ CCSF-B, with two further local maxima at $76.1 \mathrm{~m}$ CCSF-B $(574 \mu \mathrm{M})$ and at $149.8 \mathrm{~m}$ CCSF-B $(578 \mu \mathrm{M})$. Boron concentrations then decrease downcore to $230 \mu \mathrm{M}$ at $367.8 \mathrm{~m}$ CCSF-B. Deeper than this depth, boron increases again to $\sim 350 \mu \mathrm{M}$ at $550 \mathrm{~m}$ CCSF-B, decreases to $250 \mu \mathrm{M}$ at $670 \mathrm{~m}$ CCSF-B, and finally increases to $300 \mu \mathrm{M}$ deeper than $670 \mathrm{~m}$ CCSF-B.

Lithium concentrations at Site U1418 increase rapidly from $24.0 \mu \mathrm{M}$ at the core top to $29.5 \mu \mathrm{M}$ at 11.0 $\mathrm{m}$ CCSF-B (Fig. F27D). Farther downcore, lithium decreases to $13.5 \mu \mathrm{M}$ by $76.1 \mathrm{~m}$ CCSF-B and stays below $20 \mu \mathrm{M}$ to $271 \mathrm{~m}$ CCSF-B. To $452 \mathrm{~m}$ CCSF-B, lithium fluctuates between 17 and $25 \mu \mathrm{M}$. Deeper than $452 \mathrm{~m}$ CCSF-B, lithium concentrations more than double to $\sim 60 \mu \mathrm{M}$ at $544 \mathrm{~m}$ CCSF-B and then decrease to $23.5 \mu \mathrm{M}$ at $698.7 \mathrm{~m}$ CCSF-B before increasing to reach $46.5 \mu \mathrm{M}$ at the bottom of the hole.

\section{Volatile hydrocarbons}

Headspace gas samples were collected at a resolution of one per core in Holes U1418A (Cores 341U1418A-1H through 33H), U1418C (Cores 341U1418C-30H through 32H), U1418D (Cores 341U1418D-25H through 37X), and U1418F (Cores 341U1418F-7R through 72R). Methane is the dominant hydrocarbon gas detected in all samples from Site U1418, and it remains at low concentrations (generally $<5$ ppmv) down to 80.3 m CCSF-B (Fig. F26F). Methane concentrations increase rapidly downcore, especially deeper than $93.2 \mathrm{~m}$ CCSF-B and deeper than $301.5 \mathrm{~m}$ CCSF-B, and largely remain above $5,000 \mathrm{ppmv}$ to the bottom of the hole. High values $(>30,000 \mathrm{ppmv})$ are recorded at 135.9, 327.6, and $494.0 \mathrm{~m}$ CCSF-B. Deeper than $150 \mathrm{~m}$ CCSF-B, methane concentrations at or below $10,000 \mathrm{ppmv}$ tend to be associated with interbedded silt and mudstone lithologies in Holes U1418C and U1418D (see "Lithostratigraphy"), and in Hole U1418D sandy beds correspond with the low methane concentrations recorded in Cores 341-U1418D-35X (282.7 m CCSF-B). Inadvertent sampling from suck-in sediments (drilling disturbance) in Core 341-U1418C$32 \mathrm{H}$ is a possible explanation for these lower methane concentrations (see "Lithostratigraphy"). Deeper than $100 \mathrm{~m}$ CCSF-B, ethane is intermittently present in low concentrations $(<4.15 \mathrm{ppmv})$. Ethane concentrations progressively increase downcore through Hole U1418F, from $0.5 \mathrm{ppmv}(296.1 \mathrm{~m}$ CCSF-B) to 16.8 ppmv (768.6 m CCSF-B) (Fig. F26G). Between 820 and $871 \mathrm{~m}$ CCSF-B, ethane concentrations remain above $20 \mathrm{ppmv}$, reaching a maximum concentration of $119 \mathrm{ppmv}$ at $858.1 \mathrm{~m}$ CCSF-B. However, the $C_{1} / C_{2}$ ratio remains high (generally 600-60,000), implying no hazard to drilling operations.

\section{Bulk sediment geochemistry}

Discrete core samples from Site U1418 were analyzed for total carbon, total nitrogen (TN), and total inorganic carbon (TIC). From these analyses, total organic carbon (TOC) and calcium carbonate $\left(\mathrm{CaCO}_{3}\right)$ were calculated as described in "Geochemistry" in the "Methods" chapter (Jaeger et al., 2014a). In total, 44 samples were analyzed from Hole U1418A (Cores 341-U14178A-1H through 33H), 14 from Hole U1418D (Cores 341-U1418D-22H through 36X), and 59 from Hole U1418F (Cores 341-U1418F-4R through 69R). Discrete samples were selected in collaboration with the Lithostratigraphy group to ensure that the main lithologies were analyzed.

The TOC content at Site U1418 ranges between 0.2 and $1.0 \mathrm{wt} \%$ (Fig. F28A). Variability in the TOC content is superimposed on an overall downcore increase from the surface to $320.8 \mathrm{~m}$ CCSF-B, which corresponds to lithostratigraphic Unit I and Subunit IIA (see "Lithostratigraphy"). Between 350 and 450 $\mathrm{m}$ CCSF-B, TOC is $<0.6 \mathrm{wt} \%$ and then increases sharply to $0.89 \mathrm{wt} \%$ at $457.4 \mathrm{~m}$ CCSF-B. Deeper than $460 \mathrm{~m}$ CCSF-B, TOC contents decrease downcore and are largely $<0.5 \mathrm{wt} \%$ deeper than $646 \mathrm{~m}$ CCSF-B.

The TN content at Site U1418 ranges between 0 and 0.01 wt\% (Fig. F28B). Samples between 320 and 467 $\mathrm{m}$ CCSF-B are slightly lower than surrounding depths $(<0.5 \mathrm{wt} \%)$, and although higher $\mathrm{TN}$ is ob- 
served in samples with higher TOC, TN contents remain extremely low throughout Site U1418.

Organic carbon to $\mathrm{TN}(\mathrm{C} / \mathrm{N})$ ratios mostly range between 6 and 16, with an isolated maximum $\mathrm{C} / \mathrm{N}$ ratio of 22 recorded at $457.4 \mathrm{~m}$ CCSF-B. These values are consistent with a contribution from both marine and terrigenous organic matter (Hedges et al., 1986; Walinsky et al., 2009). However, the ratio is likely underestimated as a result of contributions from the inorganic $\mathrm{N}$ pool (Fig. F28E) (e.g., clay mineralbound ammonium as indicated by the positive intercept in a TOC/TN cross-plot) (e.g., Schubert and Calvert, 2001). $\mathrm{C} / \mathrm{N}$ ratios increase downcore to 400 $\mathrm{m}$ CCSF-B, followed by a deeper downcore decrease to the bottom of the hole. Both trends are largely driven by variability in the TOC rather than the TN contents. Determination of the contribution of inorganic $\mathrm{N}$ is required to fully assess the relative contributions of marine and terrigenous input to the organic matter at Site U1418.

$\mathrm{CaCO}_{3}$ values range mostly between 0 and $5 \mathrm{wt} \%$ at Site U1418 (Fig. F28D). One sample, with a $\mathrm{CaCO}_{3}$ content of $6 \mathrm{wt} \%$ ( $\sim 630 \mathrm{~m}$ CCSF-B), was taken adjacent to a suspected calcite-cemented siltstone (see "Lithostratigraphy"), which likely explains its elevated values. An overall downcore decrease in $\mathrm{Ca}$ $\mathrm{CO}_{3}$ content occurs from 2.4 to $181.35 \mathrm{~m}$ CCSF-B. Deeper than $\sim 200 \mathrm{~m}$ CCSF-B, $\mathrm{CaCO}_{3}$ content is highly variable, and no clear downcore trends are observable. In general, $\mathrm{CaCO}_{3}$ and TOC contents show inverse patterns at Site U1418.

\section{Interpretation}

Site U1418 is located close to the continental margin and the Alaska Current. The geochemistry at this site reflects the increased productivity and sediment burial associated with a proximal continental setting. The $\mathrm{CaCO}_{3}$ contents are overall low but still support the preservation of foraminifers at Site U1418 (see "Paleontology and biostratigraphy"). Variability in TOC contents could be related to the amount of marine organic matter associated with biosiliceous productivity, which may be supported by the general association between peak TOC contents and intervals of high diatom abundance (e.g., between 80 and $100 \mathrm{~m}$ CCSF-B and at $320 \mathrm{~m}$ CCSFB) (see "Paleontology and biostratigraphy"). Dissolution of biogenic opal and/or volcanic glass is indicated by dissolved silica concentrations that are almost an order of magnitude higher than those of the overlying North Pacific Deep Water $(\sim 160 \mu \mathrm{M})$. There is high variability in the silica profile at Site U1418, likely reflecting the combined influence of both silica dissolution and formation of authigenic clay minerals.

Both alkalinity and ammonium are produced near $30 \mathrm{~m}$ CCSF-B (likely related to organic matter degradation by dissimilatory iron reduction), at $\sim 70 \mathrm{~m}$ CCSF-B (likely related to anaerobic oxidation of methane in a sulfate-methane transition zone [SMTZ]), and at $\sim 150 \mathrm{~m}$ CCSF-B (likely related to an interval of intense methanogenesis, as indicated by a well-defined significant methane peak). The diagenetically most active interval between 0 and $\sim 200 \mathrm{~m}$ CCSF-B coincides with elevated diatom abundance and preservation in lithostratigraphic Unit I (see "Lithostratigraphy" and "Paleontology and biostratigraphy"), and more intense diagenesis is driven by the availability of reactive organic matter. The initially steep then more gradual downcore decrease of alkalinity deeper than $\sim 150 \mathrm{~m}$ CCSF-B is probably related to the precipitation of authigenic carbonate minerals, whereas the same pattern in the ammonium profile is probably related to its adsorption onto clay minerals (as discussed below). These processes are most intense directly beneath the lithostratigraphic Unit I/II boundary (i.e., at the top of the diamict facies) (see "Lithostratigraphy").

Based on the composition of IW, Site U1418 is divided into two biogeochemical zones, one reaching from the seafloor to $\sim 70 \mathrm{~m} \mathrm{CCSF-B}$ and the other reaching from $\sim 70 \mathrm{~m}$ CCSF-B to the bottom of the hole (Figs. F26, F27, F28, F29), but these zones do not directly correlate with lithostratigraphic unit boundaries. The shallower zone can be further divided, as the concentration profiles of manganese, iron, and sulfate follow the classical catabolic reaction sequence proposed by Froelich et al. (1979) in the uppermost $30 \mathrm{~m}$ CCSF-B at Site U1418 (Fig. F27). Dissimilatory reduction of manganese (0-2 m CCSFB) and then iron (3-30 m CCSF-B) occurs, and diffusion of the dissolved manganese and iron upward into the oxic zone leads to precipitation of authigenic manganese and iron oxides and oxyhydroxides, as seen in the brown sediment layer directly beneath the mudline at Site U1418. Downward diffusion from relative near-surface maxima probably leads to precipitation of authigenic manganese and iron carbonates, iron sulfides, and/or iron phosphates. The precipitation of iron monosulfides (e.g., greigite) is documented by black micronodules and thin bands that occur throughout the upper part of the sediment record (see "Lithostratigraphy"). The steep linear sulfate gradient from the sediment/water interface to $70 \mathrm{~m}$ CCSF-B terminates at an SMTZ, as clearly indicated by the increase in methane concentrations beneath this depth (Fig. F29). Consequently, 
the underlying sediments are methanogenic, although methane production rates appear to be variable within these deeper deposits. Slightly elevated sulfate concentrations $(<3 \mathrm{mM})$ in some IW samples deeper than the SMTZ show tentative support for the notion of a "cryptic sulfur cycle" (Holmkvist et al., 2011), whereby iron sulfides are oxidized by manganese or iron oxides and oxyhydroxides (Bottrell et al., 2000). Contamination of subsurface waters by surface seawater pumped as part of the drilling process cannot explain the presence of deep sulfate; there are no similar anomalies in the dissolved barium profile and there is no evidence for systematic barite precipitation deeper than $\sim 70$ m CCSF-B.

The diagenetic zone deeper than $70 \mathrm{~m}$ CCSF-B is denoted by both less organic matter degradation and likely increased clay mineral adsorption-desorption processes that influence a number of IW constituents. Total sulfate depletion is reached at $\sim 70 \mathrm{~m}$ CCSF-B, with the onset of methanogenesis; dissolved barium concentrations start to increase because of dissolution of barite (barium sulfate) as IW becomes undersaturated with respect to this mineral (Waterman et al., 1973). The top of the barite dissolution zone is clearly confined by the sulfate penetration depth, and precipitation of authigenic barite most likely occurs at this geochemical transition. Strontium concentrations seem to follow the barium pattern between $\sim 100$ and 200 m CCSF-B, which might be related to the relatively high strontium contents in barite. Deeper than 200 m CCSF-B, however, dissolved barium and strontium are clearly decoupled; although strontium continues to increase downcore to $\sim 700 \mathrm{~m}$ CCSF-B, the barium profile exhibits a number of sources and sinks that likely involve the interaction of barium (but not strontium) with clay minerals. At 500-600 m CCSF-B, increased degradation of organic matter by methanogenesis may release both ammonium and alkalinity into the pore space (Fig. F26). This release might be related to the availability of more labile organic matter of marine algal origin (e.g., diatoms), as indicated by dissolved silica release due to biogenic opal dissolution in the same depth interval (Fig. F26) and the decrease in C/ $\mathrm{N}$ ratios deeper than $500 \mathrm{~m}$ CCSF-B (Fig. F28). The similarity in the downcore profiles of dissolved lithium, barium, and boron deeper than $500 \mathrm{~m}$ CCSF-B is consistent with the preferential adsorption of ammonium to clay mineral surfaces, leading to its exchange for previously adsorbed lithium, boron, barium, or magnesium ions (Gieskes, 1975; Hanor and Chan, 1977; von Breymann et al., 1990; Zhang et al., 1998; James and Palmer, 2000) that are then released into solution. Re-adsorption of barium, lithium, and boron onto clay minerals in the sediments with lower dissolved ammonium concentrations might be assisted by the neoformation of authigenic clay minerals. The decrease in dissolved silica, magnesium, and potassium deeper than $600 \mathrm{~m}$ CCSF-B further supports this interpretation (Figs. F26, F27) (Gieskes, 1975; Michalopoulos and Aller, 1995; Gieskes et al., 1998). Alternatively, the removal of magnesium, potassium, barium, boron, and lithium from the IW might be related to authigenic feldspar formation (Gieskes, 1975; Kastner and Siever, 1979; Wallmann et al., 2008). It is unclear why strontium would not participate in this desorption-adsorption cycle. Overall, in this depositional setting strongly dominated by clay-rich terrigenous sedimentation, detrital and authigenic clay minerals may play a dominant role in the development of the IW chemistry in the methanogenic zone.

The patterns in IW chloride concentration, sodium, bromide, and (less indicative) salinity in the uppermost $100 \mathrm{~m}$ CCSF-B at Site U1418 are most likely related to the burial of glacial seawater in the interstitial space (Fig. F26) (McDuff, 1985; Gieskes et al., 1998). The decreases in chloride, bromide, and sodium toward the bottom of the hole are probably caused by IW dilution with freshwater released from clay mineral dehydration with increasing sediment burial depth, whereas the gradual loss of dissolved magnesium and potassium from the IW may also be due to authigenic clay mineral formation.

\section{Physical properties}

Physical properties measurements were taken on each of the six holes drilled at Site U1418 to provide basic information for characterizing the drilled section using whole-round cores, split cores, and discrete samples. After cores were divided into sections, all whole-round core sections longer than $\sim 30 \mathrm{~cm}$ were measured with the GRA bulk densitometer and magnetic susceptibility loop on the STMSL at 2.5-5.0 $\mathrm{cm}$ intervals with $2 \mathrm{~s}$ measurements. After reaching thermal equilibrium with ambient temperature after $\sim 4 \mathrm{~h}$, GRA bulk density and magnetic susceptibility were measured with the WRMSL at $2.5 \mathrm{~cm}$ intervals with $5 \mathrm{~s}$ measurements. Core disturbance, due to gas expansion between $\sim 100$ and $\sim 200$ m CCSF-B, complicated the correlation between holes and compromised the collection of core logger compressional wave ( $P$-wave) velocity data. Because of this, $P$-wave velocity (measured on the $P$-wave logger [PWL]) was only partially measured in Holes U1418A-U1418C within the upper $\sim 200 \mathrm{~m}$ CSF-A. Some damaged sections with split and/or patched core liners were too wide to fit through the WRMSL and/or the STMSL loop magnetic susceptibility meters and therefore 
could not be logged with any of the core logger instrumentation. After WRMSL scanning, whole-round sections were logged for NGR at $10 \mathrm{~cm}$ intervals. Color spectrometry, color reflectance, and magnetic susceptibility were measured on the split cores using the SHMSL at $2.5 \mathrm{~cm}$ resolution. Discrete $P$-wave and shear strength measurements were made on the working-half sections of split sediment cores from Holes U1418A, U1418B, U1418D, and U1418F on the Section Half Measurement Gantry. Moisture and density (MAD) were measured on $10 \mathrm{~cm}^{3}$ plugs collected from the working halves of Holes U1418A, U1418D, and U1418F. Summaries of all physical properties measured with the multisensor loggers on each hole (excluding Hole U1418B), as well as discrete bulk density and $P$-wave velocity, are provided in Figures F30, F31, F32, F33, and F34.

\section{Gamma ray attenuation bulk density}

Variations in GRA bulk density can reflect changes in mineralogy/lithology, consolidation, and porosity. Whole-round GRA bulk density averages $\sim 1.96 \mathrm{~g} / \mathrm{cm}^{3}$ in the APC cores and displays downhole cyclic variability on the order of $\sim 0.4 \mathrm{~g} / \mathrm{cm}^{3}$ (Figs. F30, F31, F32, F33, F34). A trend toward higher values with depth in the APC cores is consistent with increasing sediment compaction/consolidation. However, an abrupt decrease in whole-round GRA bulk density values corresponds to the depth at which we transitioned from APC core collection to XCB in Hole U1418D ( 250 m CSF-A; Fig. F32). Furthermore, GRA bulk density measured on cores retrieved with RCB coring is generally lower than the GRA bulk density of sequences retrieved with APC (see WRMSL GRA bulk density deeper than 250 m CCSF-B on Fig. F35). As outlined in "Physical properties" in the "Site U1417" chapter (Jaeger et al., 2014b), the relatively low apparent WRMSL wet bulk density partially reflects incomplete core recovery associated with the XCB and RCB coring methods, as the width of the recovered sediments fails to completely fill the core liner and the GRA bulk density measurements are therefore calibrated for a larger sediment volume than is actually contained in the XCB and RCB cores.

\section{Magnetic susceptibility}

As outlined in "Physical Properties" in the "Site U1417" chapter (Jaeger et al., 2014b), to facilitate comparison both the point-source and WRMSL loop magnetic susceptibility data sets were smoothed with a Gaussian filter of $10 \mathrm{~cm}( \pm 3 \sigma)$ and then interpolated to constant resolution. Although the relationship between point-source magnetic susceptibility and loop magnetic susceptibility appears to be linear, there is an offset in the overall magnitude of the measurements, with loop magnetic susceptibility being on average $1.58 \times$ greater than the point-source measurements in the Site U1418 APC splice (Fig. F36). We evaluate all volumetric magnetic susceptibility measurements in instrument units (IU) because of the lack of available absolute calibration standards (see "Physical properties" in the "Methods" chapter [Jaeger et al., 2014a]).

A decrease in WRMSL loop magnetic susceptibility and an increase in the difference between loop and point-source magnetic susceptibility deeper than $\sim 250 \mathrm{~m}$ CCSF-B (Fig. F35) are associated with the transition to $\mathrm{XCB} / \mathrm{RCB}$ core collection and likely reflect reduced sediment diameter in the core liner (as discussed in "Gamma ray attenuation bulk density"). The negative bias observed in the loop magnetic susceptibility associated with incompletely filled core liners is consistent with decreases in measured GRA bulk density also driven by the deviation from calibration volume, as observed in "Physical properties" in the "Site U1417" chapter (Jaeger et al., 2014b) (Fig. F35). After smoothing with a Gaussian filter of $10 \mathrm{~cm}( \pm 3 \sigma)$ to correct for the differing response function of the instruments, we can use this relationship to calculate the volume-corrected, or mass, magnetic susceptibility $(\chi)$ with units of cubic centimeter per gram (Fig. F35). Similar to the observations at Site U1417, there is a reduction in variance of $\chi$ of $\sim 25 \%$ relative to the uncorrected magnetic susceptibility record normalized by the mean core GRA bulk density, attributable to the effects of variable sediment volume. Mass magnetic susceptibility averages $\sim 50 \mathrm{~cm}^{3} / \mathrm{g}$ downhole at the site (Fig. F35). High-amplitude cyclic variability between 60 and $120 \mathrm{~cm}^{3} / \mathrm{g}$ is present at the site shallower than $\sim 250 \mathrm{~m} \mathrm{CCSF-B}$, transitioning to reduced variability centered at $\sim 40 \mathrm{~cm}^{3} / \mathrm{g}$ in the deeper sections. This corresponds with the approximate depth of APC refusal and may reflect a concurrent change in lithology and/or incomplete volumetric correction of the WRMSL volume magnetic susceptibility data. A return to higher magnetic susceptibility of $>60 \mathrm{~cm}^{3} / \mathrm{g}$ deeper than $810 \mathrm{~m}$ CCSF-B may reflect the transition to a mass transport deposit, identified and described in "Lithostratigraphy."

\section{Compressional wave velocity}

$P$-wave velocity was measured on the WRMSL PWL in Holes U1418A-U1418C (see "Physical properties" in the "Methods" chapter [Jaeger et al., 2014a]). In Holes U1418A and U1418C, velocities were measured at 0-200 m CSF-A, with reasonable measurements as deep as 110 m CSF-A (Fig. F37). Between $\sim 110$ and $180 \mathrm{~m}$ CSF-A, gas expansion prevented ac- 
curate $P$-wave measurement on the PWL because of the development of void spaces that decoupled the core material from the liner. This is an interval of elevated methane content (reaching 40,000 ppmv; see "Geochemistry"). WRMSL $P$-wave velocity values gradually increase downhole, tracking GRA bulk densities (Figs. F30, F31), ranging from $\sim 1450 \mathrm{~m} / \mathrm{s}$ at the seafloor to $\sim 1650 \mathrm{~m} / \mathrm{s}$ at $200 \mathrm{~m}$ CSF-A (Fig. F37). After switching to XCB coring in Hole U1418D, we halted PWL measurements because of inaccuracies caused by the resulting void spaces in the core.

Discrete $P$-wave measurements using the $P$-wave caliper (PWC) tool (see "Physical properties" in the "Methods" chapter [Jaeger et al., 2014a]) were taken in Holes U1418A, U1418C, U1418D, and U1418F. Discrete measurements from Holes U1418A and U1418C overlapped PWL measurements for depths shallower than $200 \mathrm{~m}$ CCSF-B (Fig. F38). PWC values were automatically picked where possible and manually picked when the automatic picker encountered errors because the calipers did not have sufficient contact with the sample because of very soft sediment or bad coupling with the liner. The PWC values appear systematically slower than the PWL measurements. A scatter plot shows that the two measurements are positively correlated but tend toward slower PWC values (Fig. F38). Care must be taken when making interpretations based on the discrete velocity data because the sampling is biased by both core recovery and sampling rate in different lithology types; however, all discrete measurements at this site were taken within the dominant lithology of the recovered interval. Measured PWL velocities show increased scatter in the interval between 110 and $180 \mathrm{~m}$ CCSF-B, an effect probably associated with gas expansion in these cores that causes the core material to become decoupled from the liner (see "Geochemistry"). Deeper than 200 m CCSF-B, the range of values narrows and slightly increases with depth to $\sim 560 \mathrm{~m}$ CCSF-B, where there is an $\sim 20$ $\mathrm{m} / \mathrm{s}$ shift in the value range to $\sim 1700 \mathrm{~m} / \mathrm{s}$ (Fig. F39). There are inflection points to higher rates of change in velocity at $\sim 700 \mathrm{~m}$ CCSF-B $(\sim 1750 \mathrm{~m} / \mathrm{s})$ and $\sim 800$ $\mathrm{m}$ CCSF-B $(>1800 \mathrm{~m} / \mathrm{s})$, with $P$-wave velocities reaching $>2000 \mathrm{~m} / \mathrm{s}$ at the bottom of the site at $\sim 900 \mathrm{~m}$ CCSF-B.

\section{Natural gamma radiation}

NGR measurements were analyzed at $10 \mathrm{~cm}$ intervals on all whole-round core sections that exceeded 50 $\mathrm{cm}$ in length, with minimum section length limited by the response function of the sodium iodide detectors (see "Physical properties" in the "Methods" chapter [Jaeger et al., 2014a]). Each measurement reflects the integration of $5 \mathrm{~min}$ of counts (i.e., $10 \mathrm{~min}$ of counting per section, consisting of $5 \mathrm{~min}$ at each of two positions separated by $10 \mathrm{~cm}$ ). NGR values show cyclical downcore fluctuations between 16 and 45 counts per second (cps) with a mean and standard deviation of 33 and 3, respectively (Fig. F40). Highfrequency variations in NGR values are likely coupled with changes in clay lithologies and consequently parallel trends in GRA bulk density and $P$ wave velocity from the core logger measurements, particularly shallower than $230 \mathrm{~m}$ CCSF-B in Holes U1418A and U1418C.

The low-frequency variability in NGR is roughly characterized by a downhole increase between 0 and 260 m CCSF-B in Holes U1418A-U1418D, although interpretation is complicated beyond this point by a decrease in recovered sediment diameter within the core liner (which depresses raw NGR counts) associated with the transition to $\mathrm{XCB}$ and $\mathrm{RCB}$ recovery. As in the case of WRMSL magnetic susceptibility, we can calculate an equivalent activity of the sediment by normalizing to the raw GRA bulk density after smoothing the data sets with a Gaussian filter of 50 $\mathrm{cm}( \pm 3 \sigma)$ to accommodate for the varying response functions of the instruments. Although this treatment reduces the overall variance in the NGR record by $\sim 20 \%$ relative to the Gaussian-smoothed uncorrected NGR data normalized by the mean core GRA bulk density, the decrease in NGR observed deeper than $\sim 200 \mathrm{~m}$ CCSF-B persists in reduced form. As in the case of magnetic susceptibility, this difference may reflect a change in lithology coincident with APC refusal and/or imperfect volume correction (Fig. F40). A transition to lower volume-normalized NGR values deeper than $810 \mathrm{~m}$ CCSF-B corresponds to lithologic changes at the Unit II/III boundary, as described in "Lithostratigraphy."

\section{Moisture and density}

Bulk density values in Holes U1418A, U1418D, and U1418F were calculated from mass and volume measurements on discrete samples taken from the working halves of split cores (see "Physical properties" in the "Methods" chapter [Jaeger et al., 2014a]). Depending on core recovery, quality, and lithology, one to three samples were taken per core. A total of 298 samples was analyzed for MAD: 80 samples from Hole U1418A, 36 samples from Hole U1418D, and 182 samples from Hole U1418F.

MAD values correspond well with WRMSL GRA bulk densities in Holes U1418A and U1418D. MAD densities increase downhole from $\sim 1.5-1.8 \mathrm{~g} / \mathrm{cm}^{3}$ at the seafloor to $\sim 1.8-2.0 \mathrm{~g} / \mathrm{cm}^{3}$ at $\sim 320 \mathrm{~m}$ CCSF-B. Deeper than $\sim 320 \mathrm{~m}$ CCSF-B, density continues to increase at a slower rate, reaching $2.2 \mathrm{~g} / \mathrm{cm}^{3}$ by $\sim 900 \mathrm{~m} \mathrm{CCSF-}$ B. Deeper than $\sim 900 \mathrm{~m}$ CCSF-B, the densities become 
more variable and increase to $\sim 2.2-2.4 \mathrm{~g} / \mathrm{cm}^{3}$ (Fig. F41).

Bulk grain density was observed to be the product of normal consolidation at $\sim 300 \mathrm{~m}$ CCSF-B (Fig. F42). Between the seafloor and $\sim 260$ m CCSF-B, grain density values are fairly constant, at $\sim 2.8 \mathrm{~g} / \mathrm{cm}^{3}$, with a small number of higher density intervals of between $\sim 3.2$ and $3.6 \mathrm{~g} / \mathrm{cm}^{3}$. Between 260 and $400 \mathrm{~m} \mathrm{CCSF-}$ $\mathrm{B}$, a secondary population of lithologies with lower bulk grain densities of $\sim 2.6 \mathrm{~g} / \mathrm{cm}^{3}$ is present. Deeper than $400 \mathrm{~m}$ CCSF-B, scatter increases, with bulk grain density values ranging from $\sim 2.5$ to $\sim 3.0 \mathrm{~g} / \mathrm{cm}^{3}$.

Porosity (percent pore space of wet sediment volume) measured on discrete samples decreases with depth, showing a normal consolidation curve. Discrete porosity values decrease rapidly from $>60 \%$ at the surface to $\sim 40 \%-44 \%$ at $\sim 70 \mathrm{~m}$ CCSF-B and then continue a more gradual decrease to $\sim 35 \%$ at $\sim 910 \mathrm{~m}$ CCSF-B (Fig. F42).

\section{Shear strength}

Shear strength measurements were performed on working section halves from Holes U1418A and U1418D using the automated vane shear testing system (see "Physical properties" in the "Methods" chapter [Jaeger et al., 2014a]). Efforts were taken to avoid the locations of obvious drilling disturbance or cracks in the half-core sample. Measurements were taken as close as possible to the positions of the MAD samples and PWC measurements.

Shear strength indicates that sediments range from very soft $(0-20 \mathrm{kPa})$ to very stiff $(120-180 \mathrm{kPa})$. Generally, the rate of change of shear strength with depth is constant downhole. Values drop slightly off the trend between $\sim 100$ and $\sim 130 \mathrm{~m}$ CCSF-B. These cores are within the interval of high methane gas levels (see "Geochemistry"), and values are slightly more scattered deeper than $\sim 150 \mathrm{~m}$ CCSF-B (Fig. F43). All samples were taken in the dominant lithology of dark gray-greenish mud, so it is unlikely that the increasing variance of shear strength measurements is due to lithology alone. Rather, as the mud gets stiffer with depth, other factors such as cracking may affect the measurement. This effect is especially apparent in the low values measured deeper than $\sim 280 \mathrm{~m}$ CCSF-B. Shear strength measurements were halted at Core 341-U1418D-37X ( 297 m CCSF-B) when samples were sufficiently hardened to break destructively upon penetration of the vane.

\section{Geothermal gradient}

Temperature measurements were conducted using the APCT-3 during APC coring in Hole U1418A. Four temperature measurements were taken in Hole
U1418A (Fig. F44), and a geothermal gradient was successfully obtained (Cores 341-U1418A-4H, 7H, $10 \mathrm{H}$, and $13 \mathrm{H}$ ) within the depth interval of 33.3$118.4 \mathrm{~m}$ CSF-A. The best-fit line of the temperature with depth measurements is shown in Figure F44B:

$$
T(z)=0.0574 z+1.8381\left(R^{2}=0.9981\right),
$$

where $T(z)$ is in situ temperature at depth $z$ (meters CSF-A). The estimated geothermal gradient is therefore $59^{\circ} \mathrm{C} / \mathrm{km}$. Again, note that this geothermal gradient was established for the depth interval shallower than 118 m CSF-A.

\section{Paleomagnetism}

The natural remanent magnetization (NRM) of the Site U1418 archive-half cores was measured before and after alternating field (AF) demagnetization. Peak AFs were restricted to a maximum of $20 \mathrm{mT}$ for all sections recovered using the APC system with standard (full and half length) and nonmagnetic core barrels (see "Operations"), the XCB system, and all but one section recovered using the RCB system (Table T14). A peak AF of $30 \mathrm{mT}$ was used on Section 341-U1418F-68R-1A. The number of demagnetization steps and the peak AF used reflected the demagnetization characteristics of the sediments, the severity of the drill string magnetic overprint, the desire to use low peak fields to preserve the magnetization for future shore-based studies, and the need to maintain core flow through the laboratory. When time permitted, additional demagnetization steps were added for sections capturing polarity transitions and the uppermost few cores of each hole to facilitate magnetic interpretation. Sections completely disturbed by drilling, as identified by the Lithostratigraphy and/or Paleomagnetism groups, were not measured. Data associated with intervals affected by obvious drilling deformation or measurement error (flux jumps; e.g., Richter et al., 2007) were culled prior to uploading or during data processing.

The NRM intensities of recovered materials were strong before $\left(10^{-1} \mathrm{~A} / \mathrm{m}\right)$ and after $\left(10^{-2}\right.$ to $\left.10^{-3} \mathrm{~A} / \mathrm{m}\right)$ demagnetization (Fig. F45). The amplitude of the higher frequency variability prior to demagnetization is significantly reduced in lithostratigraphic Unit II ( 250-800 m CCSF-B) in Hole U1418F (Fig. F20), likely reflecting the reduction of coarse material in the lower part of the sequence (see "Lithostratigraphy"). In contrast, the character of the demagnetized NRM remains essentially constant through the recovered interval, reflecting the removal of the magnetic influence of the coarsest (low coercivity) material on the paleomagnetic record. No clear cor- 
relation between core barrel type (full, half, or nonmagnetic) employed and magnetization was observed.

Transformation of depths to the CCSF-B depth scale (see "Stratigraphic correlation") allows for comparison between multiple APC-drilled holes. On the CCSF-B depth scale, intensities are consistent between holes, showing variability at both the meter and decameter scales. (Fig. F45). Steep positive inclinations observed in the APC section prior to demagnetization, consistent with a drill string magnetic overprint, are generally removed by peak AF demagnetization of $10 \mathrm{mT}$. After peak AF of $20 \mathrm{mT}$, inclinations are generally consistent with those expected (approximately $\pm 73^{\circ}$ ) for a geocentric axial dipole at the site latitude, with intervals of shallower than expected inclination also commonly observed (Fig. F46). These shallow inclinations likely reflect the influence of subtle core deformation or sediment fabric of the coarse-grained facies (see "Lithostratigraphy"). Declinations in some cores show serial correlation consistent with paleomagnetic secular variation, and in others, variability is too large and inconsistent to be geomagnetic in origin (Fig. F47).

Hole U1418F was rotary drilled to 941.18 m CCSF-B (see "Operations"). As noted above, magnetic intensities in the RCB-recovered section prior to demagnetization are lower than those in the APC-recovered section, whereas those after demagnetization are similar to, and consistent with, NRM intensities observed in the APC-recovered section (Fig. F20). A slight decrease in intensity to $10^{-3} \mathrm{~A} / \mathrm{m}$ is observed at depths deeper than 800 m CCSF-B (Fig. F20), consistent with the transition to lithostratigraphic Unit III (see "Lithostratigraphy"), although lower recovery in this interval may be a contributing factor. Inclinations within the RCB-recovered interval are consistent with expected values for the site latitude. The reduction of the coarse component within the lower part of the sequence (deeper than $250 \mathrm{~m}$ CCSF-B) allows for a high-quality paleomagnetic record. Inclinations of the RCB sections reveal an almost continuous sequence, allowing correlation to the geomagnetic polarity timescale (Cande and Kent 1995; Hilgen et al., 2012) (Fig. F20). Even though the Matuyama-Brunhes polarity transition was not completely recovered, the transition from reversed polarity in the next core deeper (Core 341-U1418F-43R) to normal polarity in the next core shallower (Core $41 \mathrm{R})$ is clear. The polarity transitions into and out of the Jaramillo (1r.1n) Subchronozone are clearly observed within Cores 57R/58R and 62R (Table T12). Two short intervals of normal polarity are observed deeper than the interval correlated with the Jara- millo Subchronozone. The deeper intervals are tentatively interpreted as the Cobb Mountain Subchronozone (C1r.2n) (Fig. F20), which is consistent with the biostratigraphic datums (see "Paleontology and biostratigraphy").

Shore-based analyses may allow refinement of these interpretations, especially within the APC-recovered section where sedimentary noise and core disturbance influenced the shipboard magnetic record. Much of the ambiguity could also result from the inability of the low level of AF demagnetization used to fully remove the drill string overprint and the inclusion of sections with minor deformation. Focusing on the splice that contains the best-recovered intervals and sampling the most pristine central part of the core should result in a noticeably improved record. Additionally, discrete sampling through polarity transitions observed within the RCB-recovered interval may improve the understanding of these features.

\section{Downhole logging Logging operations}

Logging operations at Site U1418 began after completion of RCB operations in Hole U1418F at $0730 \mathrm{~h}$ (local) on 7 July 2013 to a total depth of $948.7 \mathrm{~m}$ DSF. In preparation for logging, a short wiper trip was conducted from 830 to $945 \mathrm{~m}$ DSF, the hole was flushed with a $50 \mathrm{bbl}$ sweep of high-viscosity mud, and the RCB bit was released. The pipe was pulled to 98.6 m DSF. Three tool strings were deployed in Hole U1418F during logging operations: the triple combo tool string, the FMS-sonic tool string, and the VSI tool string (Fig. F48; see "Downhole measurements" in the "Methods" chapter [Jaeger et al., 2014a]). The triple combo tool string was modified by omitting the accelerator porosity sonde because the tool is not designed for higher porosity formations and often overestimates porosity in wide boreholes, both of which were expected at Site U1418 based on Site U1417 logging results (see "Downhole logging" in the "Site U1417" chapter [Jaeger et al., 2014b]).

The first deployment was the triple combo tool string, made up of gamma ray, density, resistivity, and magnetic susceptibility tools. The tool string was lowered into the hole at $1949 \mathrm{~h}$ on 7 July. With the tool string held stationary at $75 \mathrm{~m}$ below the end of the pipe, the wireline heave compensator settings were tested with the aim of minimizing downhole tool motion. A downlog then proceeded at a speed of $\sim 1800 \mathrm{ft} / \mathrm{h}$ to a total depth of $600 \mathrm{~m} \mathrm{WSF}$, where it 
was blocked from continued downhole progress by a bridge in the hole. The tool string was stopped in order to address a problem with the logging winch, and, during troubleshooting, the winch brakes released and $\sim 70 \mathrm{~m}$ of cable was spooled out. The tool string remained relatively stationary at the blocked section of the borehole. After fixing the winch and pulling up the spooled cable, the hole was logged upward at a speed of $900 \mathrm{ft} / \mathrm{h}$, recording data from $\sim 570$ $\mathrm{m}$ WSF uphole. No repeat pass was run because of concerns regarding the cable. The tool string was recovered to the rig floor at $0651 \mathrm{~h}$ on $8 \mathrm{July}$, and the cable was found to have several small kinks but not enough damage to warrant replacement for the duration of logging operations at this site.

The second deployment was the VSI tool string. The tool string was rigged up at $0852 \mathrm{~h}$, and Protected Species Observation began at $0900 \mathrm{~h}$. As no protected species were observed in the $940 \mathrm{~m}$ diameter exclusion zone (see "Operations"), the air gun ramp-up began at $1030 \mathrm{~h}$, and the air guns were fired every 5-15 min while the tool string was run into the hole. The tool string passed several borehole obstructions or bridges before encountering a completely blocked zone, reaching a final depth of 218 $\mathrm{m}$ WSF. Because of the softness of the relatively shallow sediments, the VSI caliper was not able to get a good clamp, even in the in-gauge intervals of the borehole between 192 and $218 \mathrm{~m}$ WSF identified by the triple combo caliper log. Consequently, all recorded waveforms were noisy and none of the shots provided clean first arrivals. The tool string was pulled up and rigged down by $1815 \mathrm{~h}$.

The final logging run in Hole U1418F was the FMSsonic tool string. The tool string was rigged up and run into the hole at $1932 \mathrm{~h}$ on 8 July. A downlog was recorded at $1800 \mathrm{ft} / \mathrm{h}$, reaching a total depth of 582 $\mathrm{m}$ WSF. The tool string was blocked from additional downhole progress by a blocked zone, $\sim 20 \mathrm{~m}$ shallower than the depth reached by the triple combo tool string. One complete full pass of the hole was recorded at a speed of $1800 \mathrm{ft} / \mathrm{h}$ before the tool string became stuck in the pipe while trying to log upward to record the seafloor. The FMS-sonic tool string was retrieved to the rig floor and rigged down by $0733 \mathrm{~h}$, and logging operations were completed by $0830 \mathrm{~h}$ on 9 July.

Seas were relatively calm for the duration of logging operations. There was an average heave of $0.85 \mathrm{~m}$ (peak to peak).

\section{Data processing and quality assessment}

All logging curves were depth-matched using the total gamma ray log from the main pass of the triple combo as a reference log, facilitating the generation of a unified depth scale. Features in gamma ray logs from the other tool string passes were aligned to the reference log to produce a complete depth-matched data set. Logging data were then depth-shifted to wireline log matched depth below seafloor (WMSF), based on the step increase in gamma radiation in the main pass of the triple combo that indicated the seafloor, measured at $3677.5 \mathrm{~m}$ wireline log depth below rig floor (WRF).

The quality of the downhole logs was affected by the range in borehole diameter (Figs. F49, F50, F51), which often exceeded the 18 inch limit of the Hostile Environment Litho-Density Sonde caliper arm. The caliper log from the triple combo run shows that borehole size varies from $\sim 10$ to $>18$ inches in diameter (Figs. F49, F50). Between the base of the pipe and $218 \mathrm{~m}$ WMSF, the borehole presents large variability in shape and numerous intervals through which the caliper arm was fully extended (i.e., washouts). Between 218 and 460 m WMSF, borehole conditions are better, with many intervals close to or at the drill bit diameter. Deeper than 460 m WMSF, hole diameter increases again in size and variability. The tool strings deployed in Hole U1418F encountered blockages at different depths between the first logging run (triple combo) and the last logging run (FMS-sonic). FMS caliper data confirm that hole conditions were deteriorating over the course of logging operations, as indicated by the appearance of bridges in the borehole that were not apparent in the earlier triple combo caliper log (see $\sim 370,380$, and $487-551$ $\mathrm{m}$ WMSF in Fig. F51).

As a result of varying borehole conditions, logging data vary in quality. Most of the logs exhibit high variability in the upper $220 \mathrm{~m}$ WMSF, especially where the hole is dominated by washouts of up to several meters in height. Data in intervals where NGR, density, and resistivity show inverse patterns with the caliper log should be interpreted with caution, as they likely reflect washed-out intervals (Figs. F49, F50). The presence of washouts, however, is likely to reflect lithology, as some sediment types are more easily washed out than others. Gamma ray, density, resistivity, magnetic susceptibility, and velocity tools seem to record good quality data outside of washed-out intervals. Magnetic susceptibility logs show reasonable responses throughout the borehole, and measurements were repeatable between the downlog and uplog passes of the triple combo. However, magnetic susceptibility measurements display drift with depth likely related to internal tool temperature, as seen in Hole U1417E Magnetic Susceptibility Sonde (MSS) data. As tool temperature increases linearly with depth, we applied the same 
method for linear correction as for Site U1417 (Fig. F52; see "Downhole logging" in the "Site U1417" chapter [Jaeger et al., 2014b]). Moreover, the factor applied to correct the temperature drift for the magnetic susceptibility measurement was the same for both sites (Fig. F52). That the same linear relationship was observed between susceptibility and temperature at two different sites allows us to be confident in the reliability of this correction, as well as in the quality of magnetic susceptibility data.

The quality of logs can also be assessed by comparison with measurements made on cores from the same site (Fig. F49). NGR from the triple combo shows good agreement with scaled shipboard core logger data, with the exception of the washed-out intervals where gamma ray log values are lower because fewer gamma rays reach the detector in a wider borehole. Between the base of the pipe and $270 \mathrm{~m}$ WMSF, logs appear to underestimate bulk density (giving values close to water density in washouts), except in discrete intervals where hole diameter is smaller (Fig. F49). From 270 to 462 m WMSF, density logs and bulk density from MAD samples show good correspondence. Deeper than 462 m WSF, density logs likely underestimate density formation again but trends between logging and core data are similar. Resistivity logs show reasonable responses throughout the borehole, although higher amplitude responses are likely due to increased borehole size. The FMS resistivity images were also dominated by poor contact with the borehole wall in the wide intervals and are generally of intermediate quality, although some well-imaged intervals exist (Fig. F53).

The Dipole Shear Sonic Imager (DSI) recorded P\&S monopole, upper dipole, and lower dipole modes during the one full pass in Hole U1418F. To optimize measurements in this slow sediment, the monopole and upper dipole utilized standard (high) frequency and the lower dipole transmitted and received lower frequencies. Data show that the DSI was able to capture both compressional and flexural wave arrivals through much of the borehole (Fig. F51). Shear wave data are limited in the shallowest $220 \mathrm{~m}$ WMSF because of patchy coherence, but flexural arrivals are more coherent below this depth. Gaps in coherence in both compressional and flexural data, along with anomalously low gamma ray signals, correspond in large part to washed-out intervals of the borehole. Postcruise processing of the sonic waveforms could improve the velocity data, particularly in intervals where $P$-wave arrivals cannot be distinguished from fluid wave arrivals.

\section{Logging stratigraphy}

The logged interval in Hole U1418F is assigned to one logging unit (Figs. F49, F50, F51) because the character of the logs changes gradually downhole with no major stepwise changes. At the scale of this unit, the total gamma ray signal ranges from 35 to 55 gAPI, with the exception of anomalously low values corresponding to washed-out intervals. The signal is generally dominated by $\mathrm{K}$ and Th content, with a minor U contribution (Fig. F50). For the most part, the three radioactive elements behave in a consistent fashion, suggesting that they are mainly responding to clay mineralogy or content. Density measurements do not show distinctive characteristics in the logged interval. Resistivity data slightly decrease with depth, which is counter to the expected increasing trend with depth due to compaction; however, slightly decreased values below $462 \mathrm{~m}$ WMSF may simply be a response to the larger borehole diameter in this interval. Magnetic susceptibility data do not trend noticeably downhole. Velocity measurements show a generally increasing trend with depth.

\section{Logging Unit 1}

Logging Unit 1 is divided into five subunits, mainly on the basis of subtle changes in the gamma ray, resistivity, and magnetic susceptibility logs (Figs. F49, F50, F51).

\section{Logging Subunit $1 A$ (base of drill pipe to $217 \mathrm{~m}$ WMSF)}

The upper logging Subunit $1 \mathrm{~A}$ is dominated by high variability in most logging data, alternating on the scale of meters between washouts and in-gauge borehole diameter (Fig. F49). Natural gamma ray logs track hole diameter, as does the resistivity log. Magnetic susceptibility is relatively low in this subunit. FMS images show alternations between moderate resistivity and very low resistivity (associated with washouts).

\section{Logging Subunit 1B (217-240 m WMSF)}

Logging Subunit 1B is distinguished by a slight increase in the baseline of the gamma ray and resistivity logs (Fig. F49). Resistivity data also decrease in amplitude compared to Subunit 1A. Magnetic susceptibility increases significantly within this subunit. FMS images (see US Implementing Organization [USIO] Log Database at iodp.ldeo.columbia.edu/ DATA/) show a general increase from moderate to higher resistivity. 


\section{Logging Subunit 1C (240-282 m WMSF)}

Logging Subunit $1 \mathrm{C}$ is distinguished from the subunit above by an increased contribution of $U$ to the total natural gamma ray signal (Fig. F50). The resistivity log shows alternating trends on the scale of meters in this subunit, from low to high amplitude (Fig. F49). The magnetic susceptibility log appears similar to that of Subunit 1A, with lower values than the overlying Subunit 1B. FMS images (see USIO Log Database at iodp.ldeo.columbia.edu/DATA/) show relatively high resistivity values throughout the subunit.

\section{Logging Subunit 1D (282-500 m WMSF)}

Gamma ray logs are generally constant with depth, varying around a mean value of 45 gAPI, outside of washouts (Fig. F49). Spectral gamma ray logs show a higher contribution of $U$ relative to the shallower and deeper subunits (Fig. F50), which may indicate a change in lithology or a decrease in the oxidation state of the upper sediment column near the time of deposition. The resistivity log displays no overall trend with depth. The mean magnetic susceptibility value is higher in this subunit, with distinct intervals of higher susceptibility between 379 and $385 \mathrm{~m}$ WMSF and at 405, 421, and $480 \mathrm{~m}$ WMSF. The interval between 379 and $385 \mathrm{~m}$ WMSF corresponds to a diamict interval in lithostratigraphic Unit IIB (see "Lithostratigraphy"), whereas the narrower highsusceptibility intervals have no direct association with distinct features described in cores. The $P$-wave velocity log shows an interval of low velocity at the logging Subunit $1 \mathrm{C} / 1 \mathrm{D}$ boundary but returns to a generally increasing trend with depth within Subunit 1D. FMS images are highly variable, ranging from moderate to high resistivity (Fig. F53).

\section{Logging Subunit 1E (500-570 m WMSF [base of logged interval])}

Logging Subunit 1E is distinguished from the shallower subunits in most of the logging measurements by the addition of a lower frequency trend with a decameter wavelength (Fig. F49). NGR counts decrease at $\sim 520 \mathrm{~m}$ WMSF and then an increase from $535 \mathrm{~m}$ WMSF to the base of the logged interval. The density log shows a similar trend that is repeated in the MAD bulk density data from cores despite the washed-out intervals (Fig. F49). The resistivity log trends with gamma ray and density logs. Resistivity decreases deeper than $550 \mathrm{~m}$ WMSF. The magnetic susceptibility log trend is generally inverted relative to the trends in gamma ray and resistivity. The $P$ wave velocity log indicates that velocities in this subunit are lower than those in Subunit 1D, but gaps in the data prevent the distinction of additional trends
(Fig. F51). FMS images (see USIO Log Database at iodp.ldeo.columbia.edu/DATA/) show variability between high and low resistivity, which may reflect the development of bridges (high resistivity and small borehole diameter) between the washed-out zones (low resistivity and large borehole diameter) within this depth interval over the course of logging operations.

\section{Formation MicroScanner images}

Despite the variability in borehole size and the presence of washed-out intervals, the FMS resistivity images reveal some local transitions between alternating resistive and conductive intervals at the meter to submeter scale. Some of these alternations correspond to the resistivity log from the triple combo (Fig. F53) and may reflect changes in sediment electrical properties related to changes in lithology from mud to diamict (see "Lithostratigraphy"). FMS resistivity images also show local features, such as individual clasts at depths corresponding to intervals with large clasts described in Site U1418 cores (Fig. F54; see "Lithostratigraphy"). In general, however, the FMS resistivity images remain dominated by poor contact with the borehole wall in the wide, washed-out intervals of the logged section (seen as dark bands that correspond to large-diameter intervals) and what may be inadequate compensation for downhole tool motion (evidenced by blurry images, even in regions of relatively small borehole size).

\section{Vertical seismic profile}

The VSI tool string was deployed in Hole U1418F in hopes of conducting a vertical seismic profile (VSP) experiment focused on in-gauge intervals of the borehole identified by the triple combo caliper log. However, the tool string was obstructed at $\sim 218 \mathrm{~m}$ WSF either by a blocked zone or by the base of the tool string lodging in a washed-out portion of the borehole wall. The VSI was not able to progress deeper into the hole where the formation was more indurated and/or lithified. The VSI tool string is relatively small and light compared to other standard IODP tool strings (i.e., VSI: $\sim 12 \mathrm{~m}$ length, $\sim 525 \mathrm{lb}$ in fluid; FMS-sonic: $\sim 33 \mathrm{~m}$ length, $\sim 1900 \mathrm{lb}$ in fluid), which is important for maximizing the anchoring force directed into the borehole wall by the VSI caliper during a VSP. However, this may also prevent the lighter tool string from passing narrow spots in the borehole and/or intervals of abrupt change in borehole diameter that can be worked past by heavier tool strings, as was the case in Hole U1418F. In the shallow interval of the hole that was accessible during the VSI run in Hole U1418F, it was difficult to achieve sufficient anchoring force with the VSI cali- 
per. The caliper was most likely pressing into the soft formation to its maximum extent without establishing a solid clamp, and therefore the sensor package in the sonde could not be fully isolated from the tool string. Although 35 shots were fired during the VSP at approximately six depth stations, all the sonic waveforms were noisy and no clear first arrivals could be distinguished.

\section{Core-log-seismic integration}

For the purposes of shipboard data correlation, we compared data displayed in the following two depth scales: WMSF (see "Downhole logging") and CCSFB (a compressed composite depth scale; see "Stratigraphic correlation") for logging and core data, respectively. Logging data are depth-matched between different tool strings using the gamma ray logs recorded on each logging run and then shifted to the WMSF depth scale based on the step increase in gamma radiation across the seafloor (see "Downhole logging" in the "Methods" chapter [Jaeger et al., 2014a]). For logging data at Site U1418, the maximum observed depth shift was $<2 \mathrm{~m}$. Core physical properties were measured in Holes U1418A-U1418F (see "Physical properties"), whereas logging data were recorded only in Hole U1418F (see "Downhole logging").

For preliminary correlation between Site U1418 lithostratigraphic and logging units with features observed in seismic data, we converted lithostratigraphic and logging unit boundaries from depth in meters (CCSF-B/WMSF) to TWT using the average velocities of each unit. Average $P$-wave velocity was derived from core physical properties measurements using data from the PWC at depths shallower than $\sim 257 \mathrm{~m}$ CCSF-B and the downhole sonic logs at depths shallower than $248 \mathrm{~m}$ CCSF-B/WMSF (see "Physical properties" and "Downhole logging," both in the "Methods" chapter [Jaeger et al., 2014a]). Deeper than $\sim 548 \mathrm{~m}$ CCSF-B/WMSF, we used values calculated from the linear trendline of the downhole sonic $\log$, though detailed correlations in this part of the core will require postcruise research.

\section{Lithostratigraphy-downhole logging data correlation}

Sediment core descriptions, whole-core physical properties measurements, and downhole logging data obtained from Site U1418 were combined in order to examine the coherence between the different data sets and evaluate the completeness of the recovered sediment record. We first compare the distribution of lithostratigraphic units with volume-cor- rected magnetic susceptibility measurements derived from cores on the WRMSL (see "Physical properties") and standardized and temperature-corrected logging measurements made with the deep-reading magnetic susceptibility sensor on the triple combo tool string (see "Downhole logging"). In addition, standardized gamma ray measurements obtained from the triple combo and FMS-sonic tool strings were compared with the recovered sediment.

Figure F55 shows the correspondence between magnetic susceptibility derived from the sediment core splice appended with that derived from Holes U1418D and U1418F and the logging data obtained from Hole U1418F between 100 and $550 \mathrm{~m}$ CCSF-B/ WMSF. In general, we note that intervals of high and low magnetic susceptibility values in the logging data correspond with similar variations in the sediment core. Good examples of this correspondence are located between 100 and 250 CCSF-B (inset diagram, Fig. F55), where low magnetic susceptibility is observed, and between 275 and 325 CCSF-B and 500 and $550 \mathrm{~m}$ CCSF-B, where we identify relatively high values in both data sets. At a finer scale $(<10 \mathrm{~m})$, we observe high magnetic susceptibility in the logging data associated with diamict and sand layers, whereas low values are observed in intervals with diatom ooze, mud with laminations, and bioturbated mud. It appears that between 430 and $475 \mathrm{~m}$ CCSF-B the correspondence between the core and log data is not as strong, particularly at $430 \mathrm{~m}$ CCSF$\mathrm{B}$, where there is a clear increase in the core magnetic susceptibility that is not seen in the log measurements. One possibility is that variations in borehole size, as revealed by caliper measurements, may influence the logged magnetic susceptibility signal. Additional postcruise work will attempt to account for these variations.

Figure F56 shows the correspondence between the lithostratigraphic units, the distribution of diatom ooze and mud with clasts, and downhole changes in $\mathrm{K}$, Th, and $\mathrm{U}$ spectral gamma radiation and total gamma radiation. Overall, there is good agreement between gamma radiation measured on the triple combo and FMS-sonic tool strings. A primary observation is that standardized gamma ray parameters (total gamma radiation, $\mathrm{K}$, Th, and $\mathrm{U}$ ) appear to be significantly influenced by borehole dimensions (see "Physical properties-downhole logging data correlation"). Deeper than $250 \mathrm{~m}$ CCSF-B, borehole dimensions and downhole natural gamma ray measurements vary less, which may correspond to the lithostratigraphic Unit I-II transition at $260 \mathrm{~m}$ CCSFB. Generally, gamma radiation, $\mathrm{K}$, and Th are lower between 125 and $175 \mathrm{~m}$ CCSF-B, which corresponds to an interval where diatom-rich mud and ooze is 
prevalent in Unit I. At the base of the logged interval, there is a prominent increase in total gamma ray, $\mathrm{Th}$, and $\mathrm{U}$ with a concomitant decline in $\mathrm{K}$. There is no obvious change in lithology at this depth, but pore water geochemical changes within this interval indicate strong organic matter degradation (see "Geochemistry"), which may impact the logged spectral gamma radiation at the base of the borehole.

\section{Physical properties-downhole logging data correlation}

In general, there seems to be a good correspondence between data on the WMSF and CCSF-B depth scales, with a vertical offset on the order of a few meters (Fig. F57). However, between the base of the pipe and $218 \mathrm{~m}$ WMSF, the borehole has numerous washed-out intervals where the logging caliper measures its maximum extent ( 18 inches). Both gamma ray and density logs present anomalously low values within these washed-out zones, compared to core measurements (Fig. F57). These two logging measurements are made through the detection of gamma rays from the formation; fewer gamma rays reach the tool detectors in a wider borehole, resulting in underestimation of gamma radiation and bulk density.

With the exception of the washed-out sections, the natural gamma ray log shows reasonable agreement with core NGR, with a similar range in values and similar features occurring within a few meters in depth (Fig. F57). The NGR data have been corrected for volume using GRA density (see "Physical properties"). The washouts shown in the caliper log generally correspond to lower gamma ray values in NGR data, which cannot be affected by borehole size the same way the logging data are affected. These washouts are likely partly controlled by lithology within the shallower part of the borehole, where the dominant lithology is interbedded silt and mud (see "Lithostratigraphy"). Silt or sand beds are more likely to washout during drilling, leading to thin intervals of enlarged borehole. This interpretation is supported by the lower gamma ray values measured on cores in some of the washouts (for example, between 170 and $250 \mathrm{~m}$ WMSF), which would be expected to correspond to a transition from mud to a more silt or sand rich formation. Deeper than this interval of frequent washouts, the gamma ray downhole logs show good agreement with the NGR data.

The density log (Fig. F57) is strongly affected by the irregular borehole size throughout much of the borehole, giving density values close to water density in washed-out intervals. However, the highest down- hole density values show reasonable correspondence with maximum bulk density values in the range of the GRA density data and show good agreement with the trends in discrete MAD measurements. Even subtle trends in density deeper than $\sim 270 \mathrm{~m}$ WMSF are mirrored in all three data sets within a few meters (for example, density variations between 500 and $550 \mathrm{~m} \mathrm{WMSF}$ ), suggesting that these are true reflections of changes in physical properties, likely corresponding to lithologic variability.

The $P$-wave velocity log indicates higher formation velocities than discrete $P$-wave core measurements over the logged interval (Fig. F57). The separation in velocity estimations increases with depth. The offset between these two measurements may be related to several factors. The discrete measurements may be biased toward lower velocity matrix material, whereas the downhole log integrates lower velocity matrix and higher velocity clasts, which were found to be a significant feature in all lithostratigraphic units described at this site (see "Lithostratigraphy"). The presence of gas in the formation may also play a critical role (see "Geochemistry" and "Physical properties"). Although gas in the formation would affect both core and downhole log velocity measurements, gas expansion in cores may have caused cracking and the development of void spaces in cores, leading to poor contact with the instrument transducers and resulting in anomalously low velocities. Despite the separation between core and log velocity estimates within the logged interval, when the general trend in $P$-wave velocity from downhole logs is extrapolated to the base of the drilled borehole, there is good agreement between extrapolated log velocity and discrete velocity data in the interval corresponding to lithostratigraphic Unit IV. This agreement suggests that the $P$-wave velocity data may be valuable for detailed postcruise correlation of core and log data with seismic images.

Magnetic susceptibility data show good agreement between the log and core measurements. Log magnetic susceptibility from the deep-reading sensor of the MSS has been corrected for the effects of tool temperature (see "Downhole logging"). Core magnetic susceptibility has been corrected for volume using GRA density, which reduced the variance in the original measurements (see "Physical properties"). General trends are reproduced in both data sets. There is a notable difference in the two methods of measurement of susceptibility between 218 and $260 \mathrm{~m}$ WMSF, corresponding to logging Subunit 1B and the Subunit $1 \mathrm{~B} / 1 \mathrm{C}$ boundary. However, this difference could be related to local susceptibility differences in sedimentary features between holes, as the 
core susceptibility in much of this interval was measured in Hole U1418D and the logging susceptibility was measured in Hole U1418F.

\section{Seismic sequences and correlation with lithostratigraphy and downhole logs}

Two seismic lines cross Site U1418: high-resolution generator-injector gun Profile GOA3202, acquired in 2004 aboard the R/V Maurice Ewing during the site survey cruise for Expedition 341 (Fig. F58; Gulick et al., 2007), and Profile STEEP07, acquired in 2008 aboard the R/V Marcus Langseth (Fig. F59; Gulick et al., 2013). Site U1418 was primarily drilled through the regional Upper Surveyor Fan sequence (Seismic Sequence III) defined by Reece et al. (2011) and the chaotic seismic facies unit that lies unconformably below Sequence III. Here, we define this unit as seismic "Unit II*." In preparation for integration with the core and downhole logging data, we further divided Seismic Sequence III into distinct seismic units that are defined by either changes in acoustic facies and/or regional correlative horizons associated with the Bering Channel and Aleutian Trench (see "Background and objectives"). Some of these seismic units are composed of multiple distinct internal packages, which are distinguished by a minor change in seismic character.

Generally, Seismic Sequence III on both profiles contains smooth, horizontal, parallel reflectors that dip slightly to the north, toward the Aleutian Trench and Bering Channel systems (see "Background and objectives"). The shallower strata of seismic Subunit IIIC gradually pinches out to the southwest, away from the abandoned Bering Channel (Fig. F59). Subunit IIIC also features a prominent reflection at $\sim 5040 \mathrm{~ms}$ TWT that separates the more seismically transparent facies (in Profile STEEP07) at the top of the unit from the continuous horizons below the reflector. Line GOA3202 resolves an additional highamplitude package of approximately four reflectors at $\sim 5100 \mathrm{~ms}$ TWT (Fig. F58). Lithologically, these high-amplitude features could be associated with thick beds of mud separated by silt-rich intervals observed within lithostratigraphic Unit I (see "Lithostratigraphy").

The boundary between seismic Subunits IIIB and IIIC at $\sim 5260 \mathrm{~ms}$ TWT is located at the top of the youngest aggradational package that comprises the northwest flank of the Bering Channel (Fig. F59). At Site U1418, this boundary marks a subtle downsection change from higher to lower amplitude horizons on the regional seismic profile. This change in amplitude is more clearly resolved on high-resolution Profile GOA3202 (Fig. F60). Based on our traveltime-depth conversions, this boundary coincides with the boundary between lithostratigraphic Units I and II at $\sim 257 \mathrm{~m}$ CCSF-B (Fig. F60). Lithologically, this boundary is defined by a change from thick beds of mud separated by silt-rich intervals (Unit I) to muddy diamict (Fig. F9I) interbedded with dark gray mud and mud with dispersed clasts (Subunit IIA).

Within seismic Subunit IIIB, two high-amplitude packages are resolved on Profile GOA3202 (Figs. F58, F60) at $\sim 5310$ and $\sim 5410 \mathrm{~ms}$ TWT. Each of these packages corresponds to a subtle change in brightness within the unit on regional seismic Profile STEEP07 (Fig. F59). The boundary between lithostratigraphic Subunits IIA and IIB ( 335 m CCSF-B) correlates to a reflector that lies between these two high-amplitude packages. Lithologically, this transition is characterized by a change from muddy diamict interbedded with dark gray mud (Subunit IIA) to dark greenish gray laminated mud (Subunit IIB) (Fig. F9H).

The seismic Subunit IIIB/IIIA boundary correlates with the boundary between logging Subunits $1 \mathrm{D}$ and 1E at $~ 500-510 \mathrm{~m}$ WMSF (Fig. F60); density and velocity $\log$ values decrease at this boundary. At the top of seismic Subunit IIIA, starting at $\sim 5540 \mathrm{~ms}$ TWT, we observe both an increase in amplitude (Fig. F60) and a shift into slightly more chaotic facies (Fig. F59). Below $~ 5750 \mathrm{~ms}$ TWT, seismic reflections are less stratified and more heterogeneous. The reflections from strata here are no longer parallel, and internal truncations and lobate geometry indicate either a more energetic depositional environment or deformation.

Lithologic boundaries separating lithostratigraphic Subunits IIB-IID and Unit III are all located within seismic Subunit IIIA. Accurate correlation at this time is not possible because of uncertainties in velocity measurements downhole. The lithostratigraphic Subunit IIB/IIC boundary is defined by a change from dark greenish gray laminated mud (Subunit IIB) to dark greenish gray massive diamict interbedded with mud (Subunit IIC). The Subunit IIC/IID boundary is characterized by a change from dark gray massive diamict interbedded with mud (Subunit IIC) to dark greenish gray laminated mud interbedded with thin-bedded diamict (Subunit IID). The lithologic transition from Subunit IID to the Unit III boundary is defined as a change to laminated and bioturbated dark gray mud with interbedded sand and silt.

Seismic Unit $\mathrm{II}^{*}$ is defined by chaotic seismic facies starting at $\sim 5880 \mathrm{~ms}$ TWT. Some internal structure can be observed within the upper $\sim 100 \mathrm{~ms}$ TWT of Unit $\mathrm{II}^{*}$ (Fig. F60). The transition out of this structure into the noncoherent facies deeper may be equivalent to the lithostratigraphic Unit III/IV boundary. Lithologically, this boundary is marked by 
a transition from laminated and bioturbated mud with interbedded sand and silt to mud and muddy diamict characterized by soft-sediment deformation and intrastratal contortions, and seismically this unit is interpreted to mark the upper portion of a MTD.

\section{References}

Armand, L.K., Crosta, X., Romero, O., and Pichon, J.-J., 2005. The biogeography of major diatom taxa in Southern Ocean sediments: 1 . Sea ice related species. Palaeogeogr., Palaeoclimatol., Palaeoecol., 223(1-2):93-126. doi:10.1016/j.palaeo.2005.02.015

Asahi, H., and Takahashi, K., 2007. A 9-year time-series of planktonic foraminifer fluxes and environmental change in the Bering Sea and the central subarctic Pacific Ocean, 1990-1999. Prog. Oceanogr., 72(4):343363. doi:10.1016/j.pocean.2006.03.021

Barron, J.A., Bukry, D., Dean, W.E., Addison, J.A., and Finney, B., 2009. Paleoceanography of the Gulf of Alaska during the past 15,000 years: results from diatoms, silicoflagellates, and geochemistry. Mar. Micropaleontol., 72(3-4):176-195. doi:10.1016/j.marmicro.2009.04.006

Bergen, F.W., and O'Neil, P., 1979. Distribution of Holocene foraminifera in the Gulf of Alaska. J. Paleontol., 53(6):1267-1292. http://www.jstor.org/stable/ 1304134

Bottrell, S.H., Parkes, R.J., Cragg, B.A., and Raiswell, R., 2000. Isotopic evidence for anoxic pyrite oxidation and stimulation of bacterial sulphate reduction in marine sediments. J. Geol. Soc. (London, U. K.), 157(4):711-714. doi:10.1144/jgs.157.4.711

Brzezinski, M.A., Villareal, T.A., and Lipschultz, F., 1998. Silica production and the contribution of diatoms to new and primary production in the central North Pacific. Mar. Ecol.: Prog. Ser., 167:89-104. doi:10.3354/ meps 167089

Cande, S.C., and Kent, D.V., 1995. Revised calibration of the geomagnetic polarity timescale for the Late Cretaceous and Cenozoic. J. Geophys. Res.: Solid Earth, 100(B4):6093-6095. doi:10.1029/94JB03098

Chambers, S.R., and Cranston, R.E., 1991. Interstitial-water geochemistry of Kerguelen Plateau sediments. In Barron, J., Larsen, B., et al., Proc. ODP, Sci. Results, 119: College Station, TX (Ocean Drilling Program), 347-374. doi:10.2973/odp.proc.sr.119.169.1991

Cowan, E.A., Brachfeld, S.A., Powell, R.D., and Schoolfield, S.C., 2006. Terrane-specific rock magnetic characteristics preserved in glacimarine sediment from southern coastal Alaska. Can. J. Earth Sci., 43(9):1269-1282. doi:10.1139/e06-042

Cowan, E.A., Seramur, K.C., Cai, J., and Powell, R.D., 1999. Cyclic sedimentation produced by fluctuations in meltwater discharge, tides and marine productivity in an Alaskan fjord. Sedimentology, 46(6):1109-1126. doi:10.1046/j.1365-3091.1999.00267.x de Vernal, A., and Pedersen, T.F., 1997. Micropaleontology and palynology of Core PAR87A-10: a 23,000 year record of paleoenvironmental changes in the Gulf of Alaska, northeast North Pacific. Paleoceanography, 12(6):821-830. doi:10.1029/97PA02167

Dugdale, R.C., Wilkerson, F.P., and Minas, H.J., 1995. The role of a silicate pump in driving new production. DeepSea Res., Part 1, 42(5):697-719. doi:10.1016/09670637(95)00015-X

Fulthorpe, C.S., Hoyanagi, K., Blum, P., and the Expedition 317 Scientists, 2011. Proc. IODP, 317: Tokyo (Integrated Ocean Drilling Program Management International, Inc.). doi:10.2204/iodp.proc.317.2011

Froelich, P.N., Klinkhammer, G.P., Bender, M.L., Luedtke, N.A., Heath, G.R., Cullen, D., Dauphin, P., Hammond, D., Hartman, B., and Maynard, V., 1979. Early oxidation of organic matter in pelagic sediments of the eastern equatorial Atlantic: suboxic diagenesis. Geochim. Cosmochim. Acta, 43(7):1075-1090. doi:10.1016/00167037(79)90095-4

Gasser, D., Bruand, E., Stüwe, K., Foster, D.A., Schuster, R., Fügenschuh, B., and Pavlis, T., 2011. Formation of a metamorphic complex along an obliquely convergent margin: structural and thermochronological evolution of the Chugach Metamorphic Complex, southern Alaska. Tectonics, 30(2):TC2012. doi:10.1029/ 2010TC002776

Gehrels, G.E., and Berg, H.C., 1994. Geology of southeastern Alaska. In Plafker, G., and Berg, H.C. (Eds.), The Geology of North America (Vol. G): The Geology of Alaska: Boulder, CO (Geol. Soc. Am.), 451-468.

Gehrels, G.E., and Saleeby, J.B., 1987. Geologic framework, tectonic evolution, and displacement history of the Alexander terrane. Tectonics, 6(2):151-173. doi:10.1029/TC006i002p00151

Gieskes, J.M., 1975. Chemistry of interstitial waters of marine sediments. Annu. Rev. Earth Planet. Sci., 3:433453. doi:10.1146/annurev.ea.03.050175.002245

Gieskes, J.M., Schrag, D., Chan, L.-H., Zhang, L., and Murray, R.W., 1998. Geochemistry of interstitial waters. In Saunders, A.D., Larsen, H.C., and Wise, S.W., Jr. (Eds.), Proc. ODP, Sci. Results, 152: College Station, TX (Ocean Drilling Program), 293-305. doi:10.2973/ odp.proc.sr.152.228.1998

Gulick, S.P.S., Lowe, L.A., Pavlis, T.L., Gardner, J.V., and Mayer, L.A., 2007. Geophysical insights into the Transition fault debate: propagating strike slip in response to stalling Yakutat block subduction in the Gulf of Alaska. Geology, 35(8):763-766. doi:10.1130/G23585A.1

Gulick, S.P.S., Reece, R.S., Christeson, G.L., van Avendonk, H., Worthington, L.L., and Pavlis, T.L., 2013. Seismic images of the Transition fault and the unstable YakutatPacific-North American triple junction. Geology, 41(5):571-574. doi:10.1130/G33900.1

Gupta, S.M., 2002. Pyloniid stratigraphy-a new tool to date tropical radiolarian ooze from the central tropical Indian Ocean. Mar. Geol., 184(1-2):85-93. doi:10.1016/ S0025-3227(01)00276-6

Gupta, S.M., and Fernandes, A.A., 1997. Quaternary radiolarian faunal changes in the central Indian Ocean: infer- 
ences to oscillating hydrographic front at $10^{\circ}$ south of Equator. Curr. Sci., 72:965-972. http://www.currentscience.ac.in/Downloads/arti-

cle_id_072_12_0965_0972_0.pdf

Hamme, R.C., Webley, P.W., Crawford, W.R., Whitney, F.A., DeGrandpre, M.D., Emerson, S.R., Eriksen, C.C., Giesbrecht, K.E., Gower, J.F.R., Kavanaugh, M.T., Peña, M.A., Sabine, C.L., Batten, S.D., Coogan, L.A., Grundle, D.S., and Lockwood, D., 2010. Volcanic ash fuels anomalous plankton bloom in subarctic northeast Pacific. Geophys. Res. Lett., 37(19):L19604. doi:10.1029/2010GL044629

Hanor, J.S., and Chan, L.-H., 1977. Non-conservative behavior of barium during mixing of Mississippi River and Gulf of Mexico waters. Earth Planet. Sci. Lett., 37(2):242-250. doi:10.1016/0012-821X(77)90169-8

Hasle, G.R., and Syvertsen, E.E., 1996. Marine diatoms. In Tomas, C.R. (Ed.), Identifying Marine Diatoms and Dinoflagellates: San Diego (Academic Press), 5-385. doi:10.1016/B978-012693015-3/50005-X

Hedges, J.I., Clark, W.A., Quay, P.D., Richey, J.E., Devol, A.H., and Santos, U.D., 1986. Compositions and fluxes of particulate organic material in the Amazon River. Limnol. Oceanogr., 31(4):717-738. doi:10.4319/ 10.1986.31.4.0717

Hilgen, F.J., Lourens, L.J., and Van Dam, J.A., 2012. The Neogene period. In Gradstein, F.M., Ogg, J.G., Schmitz, M.D., and Ogg, G.M. (Eds.), The Geologic Time Scale: Oxford (Elsevier), 923-978. doi:10.1016/B978-0-44459425-9.00029-9

Holmkvist, L., Ferdelman, T.G., and Jørgensen, B.B., 2011. A cryptic sulphur cycle driven by iron in the methane zone of marine sediment (Aarhus Bay, Denmark). Geochim. Cosmochim. Acta, 75(12):3581-3599. doi:10.1016/ j.gca.2011.03.033

Jaeger, J.M., Gulick, S.P.S., LeVay, L.J., Asahi, H., Bahlburg, H., Belanger, C.L., Berbel, G.B.B., Childress, L.B., Cowan, E.A., Drab, L., Forwick, M., Fukumura, A., Ge, S., Gupta, S.M., Kioka, A., Konno, S., März, C.E., Matsuzaki, K.M., McClymont, E.L., Mix, A.C., Moy, C.M., Müller, J., Nakamura, A., Ojima, T., Ridgway, K.D., Rodrigues Ribeiro, F., Romero, O.E., Slagle, A.L., Stoner, J.S., St-Onge, G., Suto, I., Walczak, M.H., and Worthington, L.L., 2014a. Methods. In Jaeger, J.M., Gulick, S.P.S., LeVay, L.J., and the Expedition 341 Scientists, Proc. IODP, 341: College Station, TX (Integrated Ocean Drilling Program). doi:10.2204/iodp.proc.341.102.2014

Jaeger, J.M., Gulick, S.P.S., LeVay, L.J., Asahi, H., Bahlburg, H., Belanger, C.L., Berbel, G.B.B., Childress, L.B., Cowan, E.A., Drab, L., Forwick, M., Fukumura, A., Ge, S., Gupta, S.M., Kioka, A., Konno, S., März, C.E., Matsuzaki, K.M., McClymont, E.L., Mix, A.C., Moy, C.M., Müller, J., Nakamura, A., Ojima, T., Ridgway, K.D., Rodrigues Ribeiro, F., Romero, O.E., Slagle, A.L., Stoner, J.S., St-Onge, G., Suto, I., Walczak, M.H., and Worthington, L.L., 2014b. Site U1417. In Jaeger, J.M., Gulick, S.P.S., LeVay, L.J., and the Expedition 341 Scientists, Proc. IODP, 341: College Station, TX (Integrated Ocean Drilling Program). doi:10.2204/ iodp.proc.341.103.2014
James, R.H., and Palmer, M.R., 2000. Marine geochemical cycles of the alkali elements and boron: the role of sediments. Geochim. Cosmochim. Acta, 64(18):3111-3122. doi:10.1016/S0016-7037(00)00418-X

Kamikuri, S., Motoyama, I., and Nishimura, A., 2008. Radiolarian assemblages in surface sediments along longitude $175^{\circ} \mathrm{E}$ in the Pacific Ocean. Mar. Micropaleontol., 69(2):151-172. doi:10.1016/j.marmicro.2008.07.005

Kamikuri, S., Nishi, H., and Motoyama, I., 2007. Effects of late Neogene climatic cooling on North Pacific radiolarian assemblages and oceanographic conditions. Palaeogeogr., Palaeoclimatol., Palaeoecol., 249(3-4):370-392. doi:10.1016/j.palaeo.2007.02.008

Kastner, M., and Siever, R., 1979. Low temperature feldspars in sedimentary rocks. Am. J. Sci., 279(4):435-479. doi:10.2475/ajs.279.4.435

Keller, G., 1980. Benthic foraminifers and paleobathymetry of the Japan Trench area, Leg 57, Deep Sea Drilling Project. In Scientific Party, Init. Repts. DSDP, 56, 57: Washington, DC (U.S. Govt. Printing Office), 835-865. doi:10.2973/dsdp.proc.5657.124.1980

Kennett, J.P., Rozo-Vera, G.A., and Machain Castillo, M.L., 2000. Latest Neogene planktonic foraminiferal biostratigraphy of the California margin. In Lyle, M., Koizumi, I., Richter, C., and Moore, T.C. (Eds.), Proc. ODP, Sci. Results, 167: College Station, TX (Ocean Drilling Program), 41-62. doi:10.2973/odp.proc.sr.167.212.2000

Koizumi, I., 2008. Diatom-derived SSTs ( $T d^{\prime}$ ratio) indicate warm seas off Japan during the middle Holocene (8.23.3 kyr BP). Mar. Micropaleontol., 69(3-4):263-281. doi:10.1016/j.marmicro.2008.08.004

Kucera, M., and Kennett, J.P., 2000. Biochronology and evolutionary implications of late Neogene California margin planktonic foraminiferal events. Mar. Micropaleontol., 40(1-2):67-81. doi:10.1016/

S0377-8398(00)00029-3

Kuroyanagi, A., Kawahata, H., Nishi, H., and Honda, M.C., 2008. Seasonal to interannual changes in planktonic foraminiferal assemblages in the northwestern North Pacific: sediment trap results encompassing a warm period related to El Niño. Palaeogeogr., Palaeoclimatol., Palaeoecol., 262(1-2):107-127. doi:10.1016/ j.palaeo.2008.02.012

Ladd, C., Mordy, C.W., Kachel, N.B., and Stabeno, P.J., 2007. Northern Gulf of Alaska eddies and associated anomalies. Deep-Sea Res., Part I, 54(4):487-509. doi:10.1016/j.dsr.2007.01.006

Matul, A., Abelmann, A., Tiedemann, R., Kaiser, A., and Nürnberg, D., 2002. Late Quaternary polycystine radiolarian datum events in the Sea of Okhotsk. Geo-Mar. Lett., 22(1):25-32. doi:10.1007/s00367-002-0093-y

McDuff, R.E., 1985. The chemistry of interstitial waters, Deep Sea Drilling Project Leg 86. In Heath, G.R., Burckle, L.H., et al., Init. Repts. DSDP, 86: Washington, DC (U.S. Govt. Printing Office), 675-687. doi:10.2973/ dsdp.proc.86.131.1985

Medlin, L.K., and Priddle, J. (Eds.), 1990. Polar Marine Diatoms: Cambridge (British Antarct. Surv.). 
Michalopoulos, P., and Aller, R.C., 1995. Rapid clay mineral formation in Amazon delta sediments: reverse weathering and oceanic elemental cycles. Science, 270(5236):614-617. doi:10.1126/sci-

ence. 270.5236 .614

Molnia, B.F., and Hein, J.R., 1982. Clay mineralogy of a glacially dominated, subarctic continental shelf: northeastern Gulf of Alaska. J. Sediment. Petrol., 52(2):515527. doi:10.1306/212F7F90-2B24-11D78648000102C1865D

Plafker, G., 1987. Regional geology and petroleum potential of the northern Gulf of Alaska continental margin. In Scholl, D.W., Grantz, A., and Vedder, J.G. (Eds.), Petroleum Geology Potential of the Continental Margin of Western North America and Adjacent Ocean Basins. Earth Sci. Ser. (N. Y.), 6:229-268.

Plafker, G., Moore, J.C., and Winkler, G.R., 1994. Geology of the southern Alaska margin. In Plafker, G., and Berg, H.C. (Eds.), The Geology of North America (Vol. G): The Geology of Alaska: Boulder, CO (Geol. Soc. Am.), 389449.

Powell, R.D., and Molnia, B.F., 1989. Glacimarine sedimentatary processes, facies and morphology of the southsoutheast Alaska shelf and fjords. Mar. Geol., 85(24):359-390. doi:10.1016/0025-3227(89)90160-6

Reece, R.S., Gulick, S.P.S., Christeson, G.L., and Horton, B.K., submitted. Seismicity and major submarine slope on a glacial margin. Geology.

Reece, R.S., Gulick, S.P.S., Horton, B.K., Christeson, G.L., and Worthington, L.L., 2011. Tectonic and climatic influence on the evolution of the Surveyor fan and channel system, Gulf of Alaska. Geosphere, 7(4):830844. doi:10.1130/GES00654.1

Richter, C., Acton, G., Endris, C., and Radsted, M., 2007. Handbook for shipboard paleomagnetists. ODP Tech. Note, 34. doi:10.2973/odp.tn.34.2007

Sakshaug, E., 2004. Primary and secondary production in the Arctic Seas. In Stein, R., and Macdonald, R.W. (Eds.), The Organic Carbon Cycle in the Arctic Ocean: Heidelberg (Springer-Verlag), 57-82. doi:10.1007/978-3-64218912-8_3

Sancetta, C., 1982. Distribution of diatom species in surface sediments of the Bering and Okhotsk Seas. Micropaleontology, 28(3):221-257. doi:10.2307/1485181

Sautter, L.R., and Thunell, R.C., 1989. Seasonal succession of planktonic foraminifera: results from a four-year time-series sediment trap experiment in the northeast Pacific. J. Foraminiferal Res., 19(4):253-267. doi:10.2113/gsjfr.19.4.253

Schubert, C.J., and Calvert, S.E., 2001. Nitrogen and carbon isotopic composition of marine and terrestrial organic matter in Arctic Ocean sediments: implications for nutrient utilization and organic matter composition. Deep-Sea Res., Part I, 48(3):789-810. doi:10.1016/ S0967-0637(00)00069-8
Shipboard Scientific Party, 2000. Site 1149. In Plank, T., Ludden, J.N., Escutia, C., et al., Proc. ODP, Init. Repts., 185: College Station, TX (Ocean Drilling Program), 1190. doi:10.2973/odp.proc.ir.185.104.2000

Sisson, V.B., Poole, A.R., Harris, N.R., Cooper Burner, H., Pavlis, T.L., Copeland, P., Donelick, R.A., and McClelland, W., 2003. Geochemical and geochronologic constraints for genesis of a tonalite-trondhjemite suite and associated mafic intrusive rocks in the eastern Chugach Mountains, Alaska: a record of ridge-transform subduction. In Sisson, V.B., Roeske, S.M., and Pavlis, T.L. (Eds.), Geology of a Transpressional Orogen Developed During Ridge-Trench Interaction Along the North Pacific Margin: Spec. Pap.-Geol. Soc. Am., 371:293-326. doi:10.1130/ 0-8137-2371-X.293

Smith, W.O., Jr., Baumann, M.E.M., Wilson, D.L., and Aletsee, L., 1987. Phytoplankton biomass and productivity in the marginal ice zone of the Fram Strait during summer 1984. J. Geophys. Res.: Oceans, 92(C7):67776786. doi:10.1029/JC092iC07p06777

Stabeno, P.J., Bond, N.A., Hermann, A.J., Kachel, N.B., Mordy, C.W., and Overland, J.E., 2004. Meteorology and oceanography of the northern Gulf of Alaska. Continent. Shelf Res., 24(7-8):859-897. doi:10.1016/ j.csr.2004.02.007

von Breymann, M.T., Collier, R., and Suess, E., 1990. Magnesium adsorption and ion exchange in marine sediments: a multicomponent model. Geochim. Cosmochim. Acta, 54(12):3295-3313. doi:10.1016/ 0016-7037(90)90286-T

Walinsky, S.E., Prahl, F.G., Mix, A.C., Finney, B.P., Jaeger, J.M., and Rosen, G.P., 2009. Distribution and composition of organic matter in surface sediments of coastal southeast Alaska. Cont. Shelf Res., 29(13):1565-1579. doi:10.1016/j.csr.2009.04.006

Wallmann, K., Aloisi, G., Haeckel, M., Tishchenko, P., Pavlova, G., Greinert, J., Kutterolf, S., and Eisenhauer, A., 2008. Silicate weathering in anoxic marine sediments. Geochim. Cosmochim. Acta, 72(12):2895-2918. doi:10.1016/j.gca.2008.03.026

Waterman, L.S., Sayles, F.L., and Manheim, F.T., 1973. Appendix II: interstitial water studies on small core samples, Legs 16, 17, and 18. In Kulm, L.D., von Huene, R., et al., Init. Repts. DSDP, 18: Washington (U.S. Govt. Printing Office), 1001-1012. doi:10.2973/ dsdp.proc.18.app2.1973

Welling, L.A., and Pisias, N.G., 1993. Seasonal trends and preservation biases of polycystine radiolaria in the northern California Current System. Palecoceanography, 8(3):351-372. doi:10.1029/93PA00384

Yanagisawa, Y., and Akiba, F., 1998. Refined Neogene diatom biostratigraphy for the northwest Pacific around Japan, with an introduction of code numbers for selected diatom biohorizons. Chishitsugaku Zasshi, 104(6):395-414. doi:10.5575/geosoc.104.395 
Zhang, L., Chan, L.-H., and Gieskes, J.M., 1998. Lithium isotope geochemistry of pore waters from Ocean Drilling Program Sites 918 and 919, Irminger Basin. Geochim. Cosmochim. Acta, 62(14):2437-2450. doi:10.1016/ S0016-7037(98)00178-1
Publication: 22 November 2014

MS 341-104 
Figure F1. Perspective view of the northern Gulf of Alaska, showing major tectonic elements (black $=$ thrust faults). Relief is shown at $\sim 10 \times$ vertical exaggeration, with total vertical relief ranging from $<4000 \mathrm{~m}$ below sea level to $>5000 \mathrm{~m}$ above sea level. Green $=$ seismic profiles from Cruise EW0408. Orange $=$ seismic profiles from the St. Elias Erosion and Tectonics Project (STEEP) draped over topography. Black line = USGS line F-6-89-GA26. Figure modified from Gulick et al. (2013).

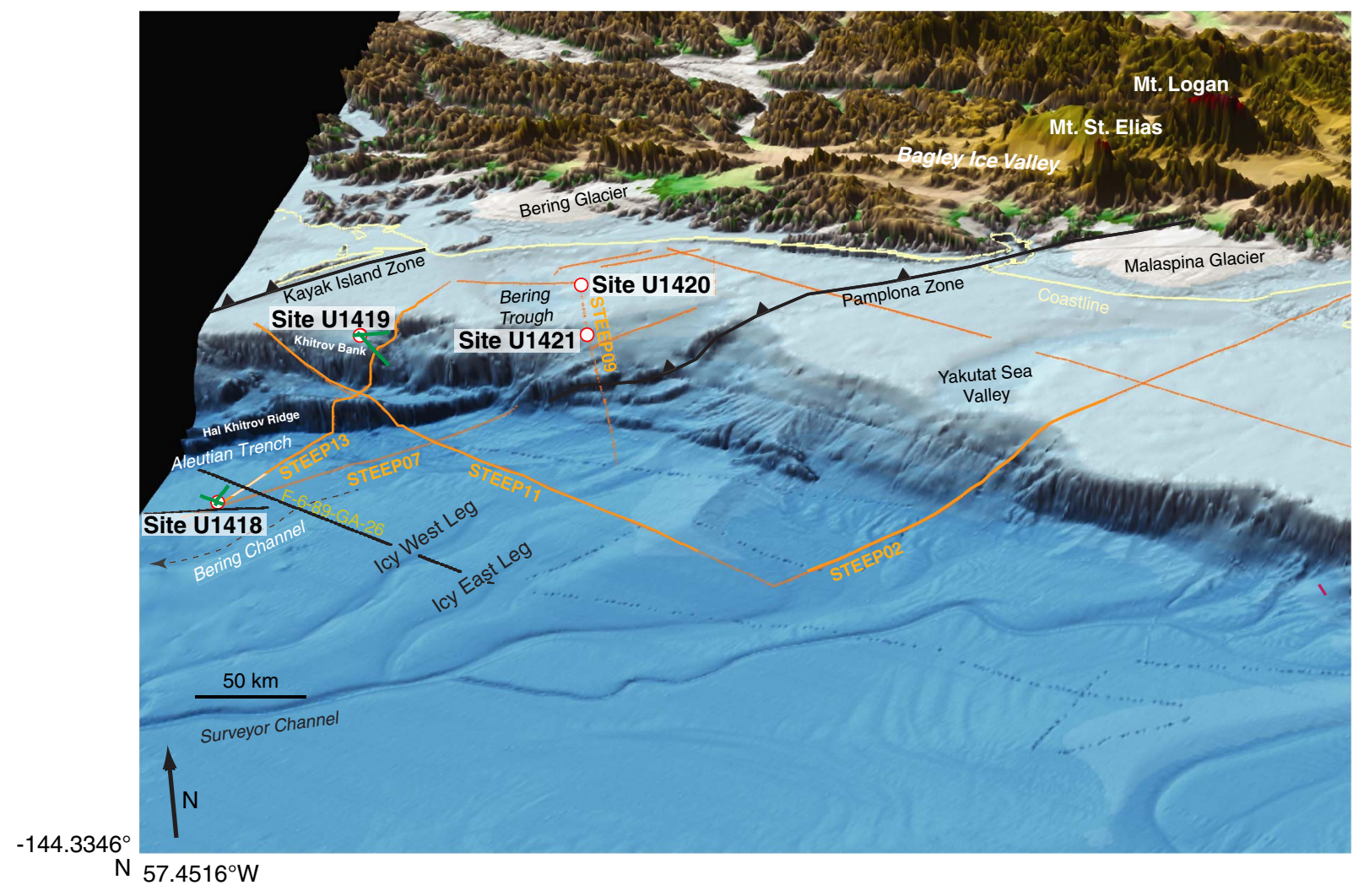


Figure F2. STEEP13 seismic section and high-resolution seismic Profile GOA3201 (inset), showing typical seismic facies of Seismic Sequence III on the proximal Surveyor Fan. Site U1418 was intended to penetrate all of Sequence III and bottom in a proposed mass transport deposit (MTD; Surveyor Slide). STEEP13 images published in Reece et al. (submitted) and Gulick et al. (2013). Common depth point (CDP) for the respective lines noted across the top of the profiles. Vertical scale bar based on seismic velocity of $1650 \mathrm{~m} / \mathrm{s}$. The location of crossing seismic profiles is shown at the top of the profiles. Green line = estimated total depth penetration for site. Black line $=$ estimated total depth of penetration.

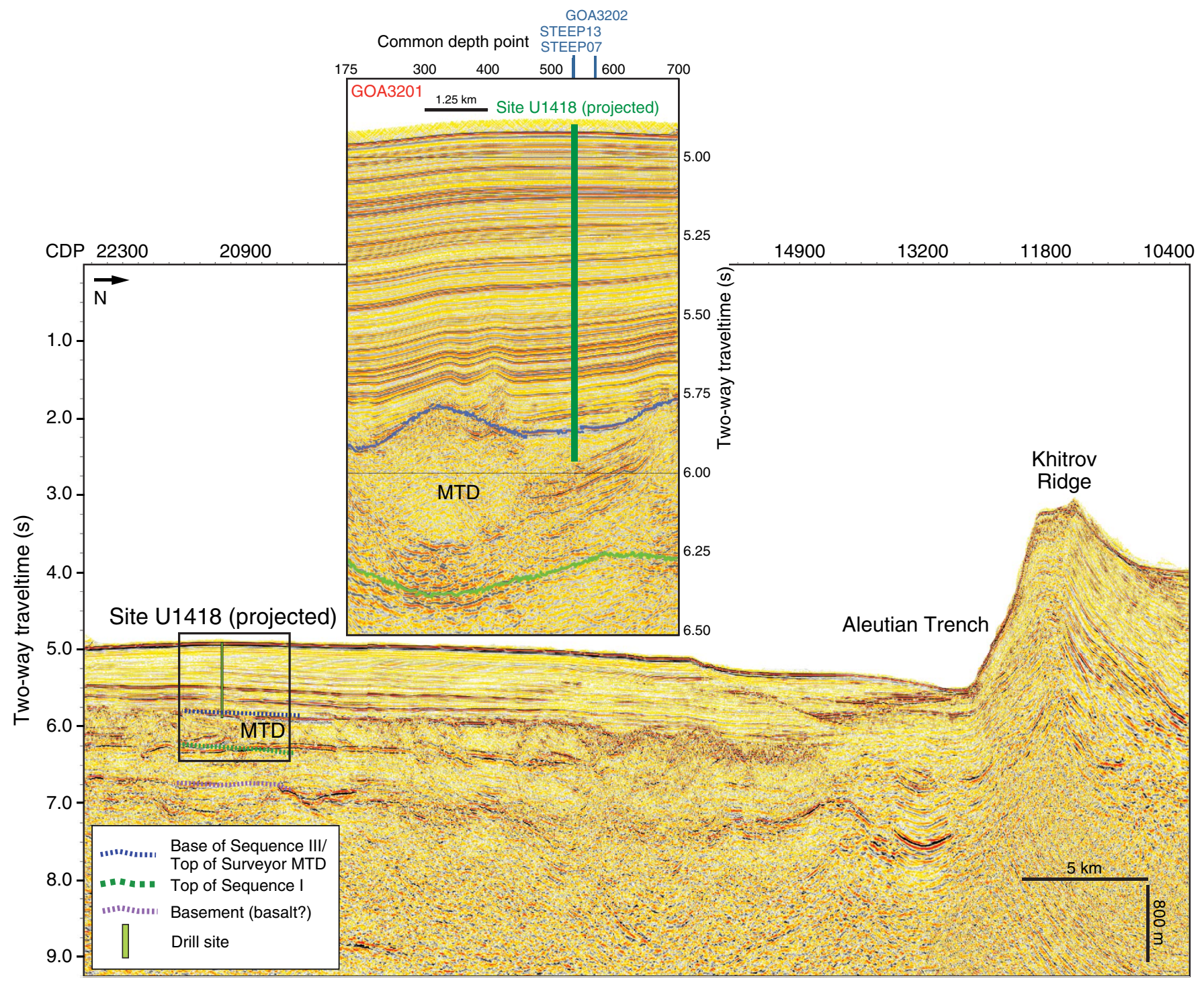


Figure F3. Uninterpreted (top) and interpreted (bottom) seismic reflection Line F-6-89-GA-26, $\sim 10 \mathrm{~km}$ northeast of Site U1418, showing channel features, including high-amplitude reflectors at base of abandoned "Bering Channel." Seismic subunits are based on lateral heterogeneity and amplitude of reflectors. Vertical scale bar based on sound velocity of $1500 \mathrm{~m} / \mathrm{s}$. The location of crossing seismic profiles is shown at the top of the profile. Black line = estimated total depth of penetration.
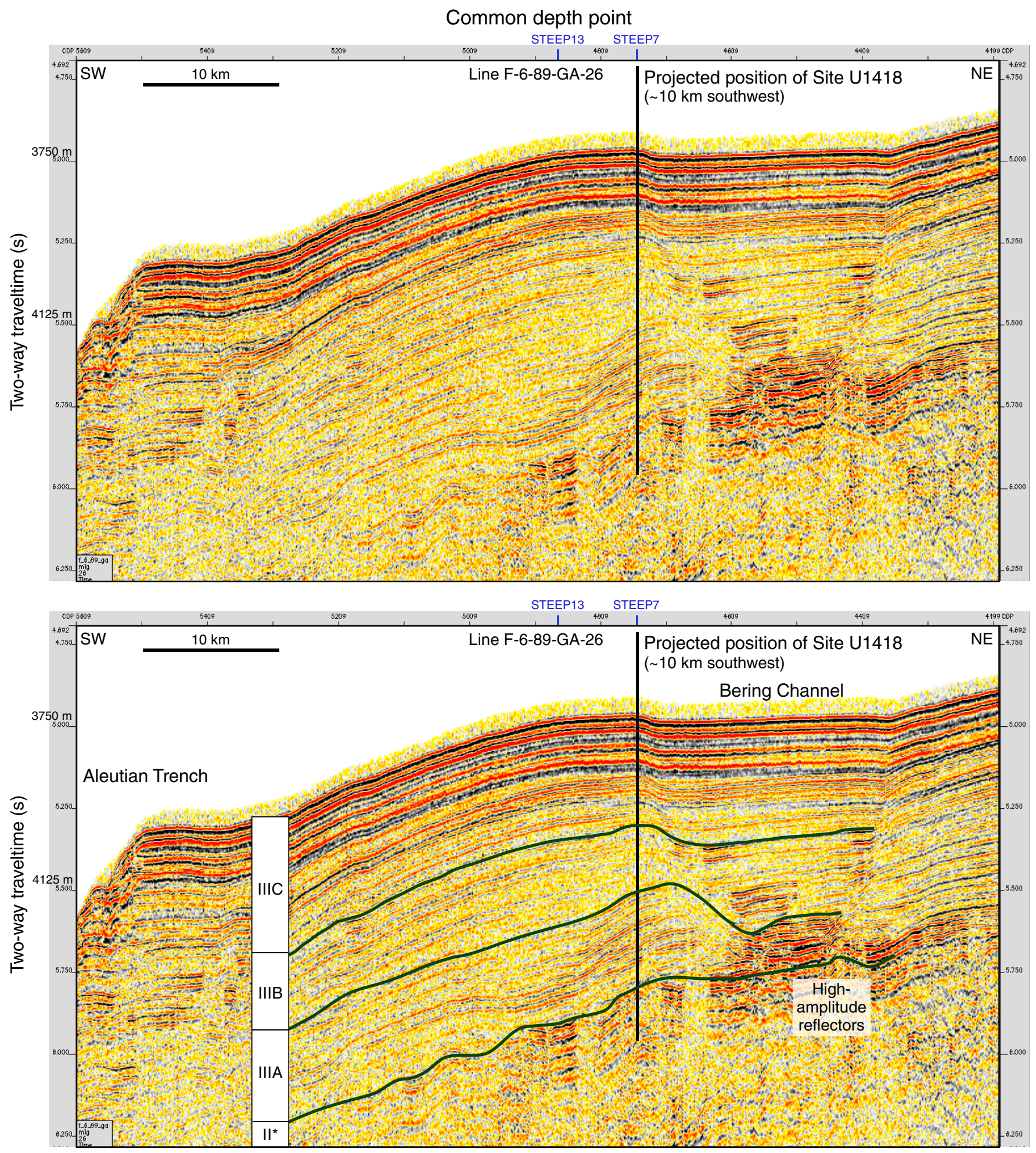
Figure F4. Navigation map, showing profiles and select shot points for two high-resolution generator-injector gun profiles, GOA3201 and GOA3202, and two crustal-scale St. Elias Erosion and Tectonics Project (STEEP) profiles, STEEP13 and STEEP07. Inset shows location of proposed Expedition 341 sites and drilled Site U1418. Common depth point locations are labeled for each line.

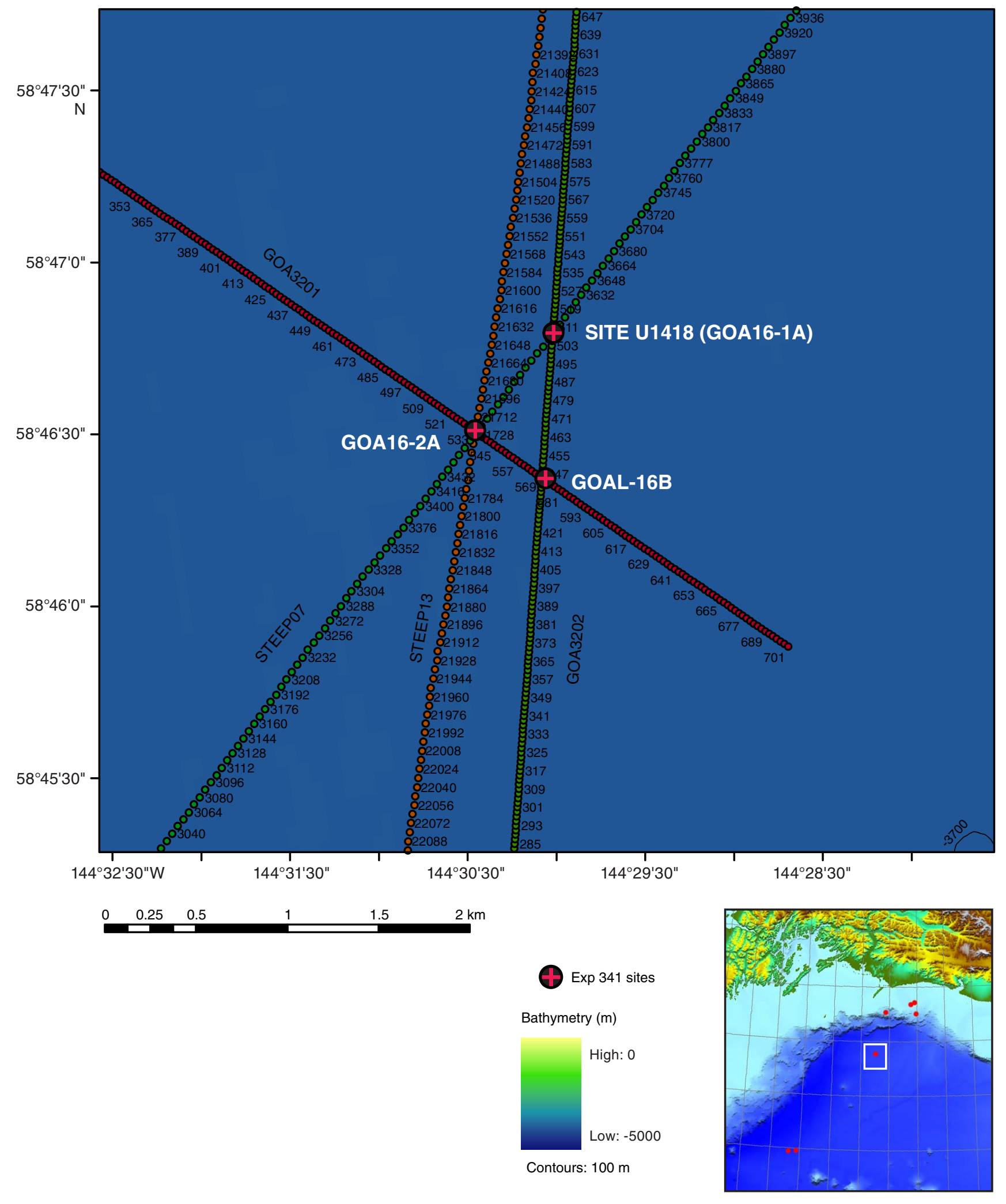


Figure F5. Uninterpreted (top) and interpreted (bottom) high-resolution generator-injector gun Profile GOA3202. The Surveyor mass transport deposit (MTD; Reece et al., submitted) is labeled. Seismic Sequence III is divided into subunits above the MTD. See "Background and objectives" and "Core-log-seismic integration" for details. The trace number (TRC), common depth point (CDP), and shot point (SP) for the line are noted across the top of the profile. The location of crossing seismic profiles is shown at the top of the profile. Black line $=$ estimated total depth of penetration.
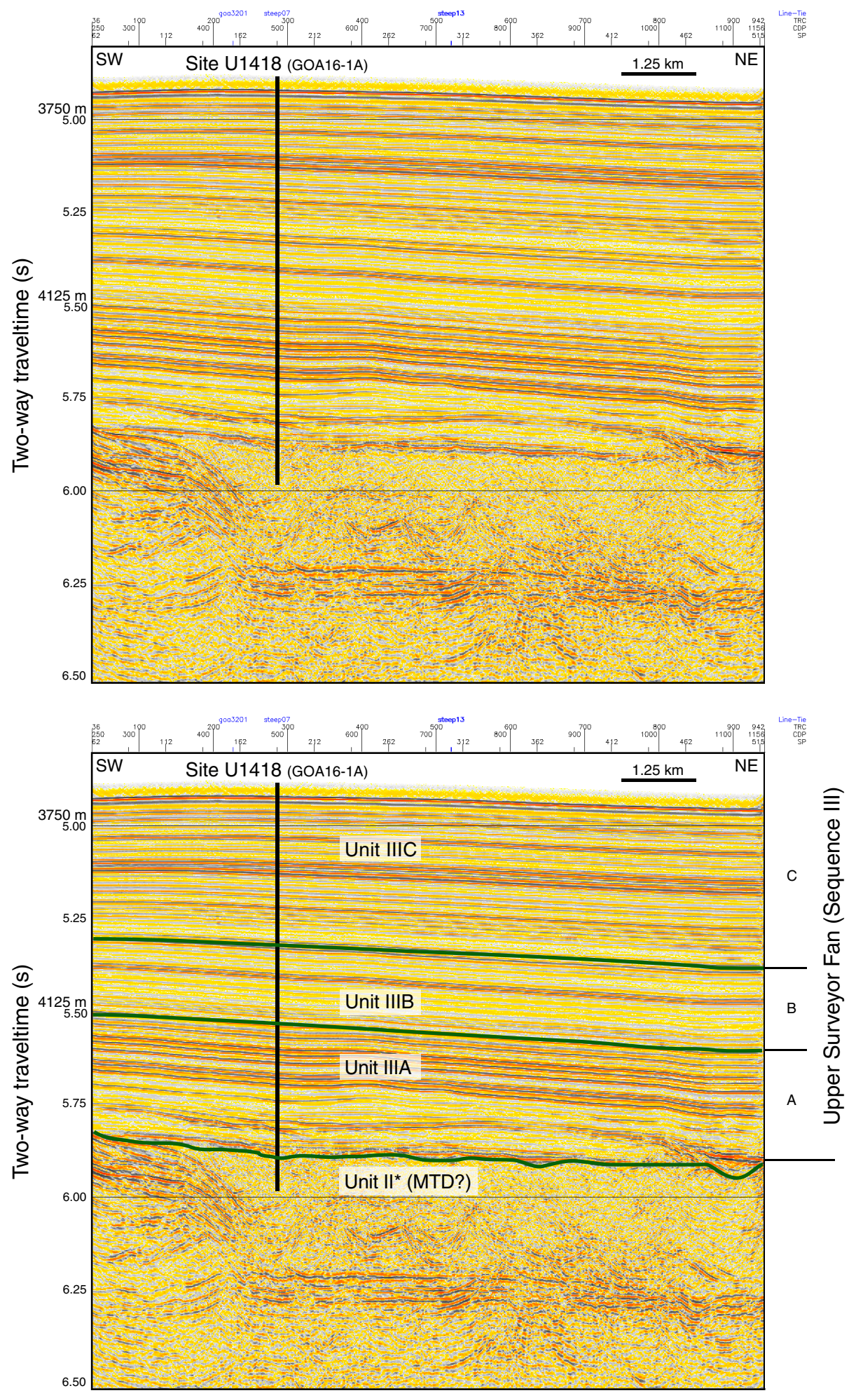
Figure F6. (A) Uninterpreted and (B) interpreted STEEP07 seismic section, showing seismic facies of Seismic Sequence III on the proximal Surveyor Fan and buried mass-transport deposit (MTD; Reece et al., submitted). Proposed drill sites for the proximal fan penetrate all of Sequence III and bottom in a proposed MTD (Surveyor Slide). This line is oblique to Line F-6-89-Line26 and reveals a portion of the abandoned "Bering Channel" and erosion within the Aleutian Trench Channel. A portion of the STEEP07 images published in Reece et al. (submitted) and Gulick et al. (2013).

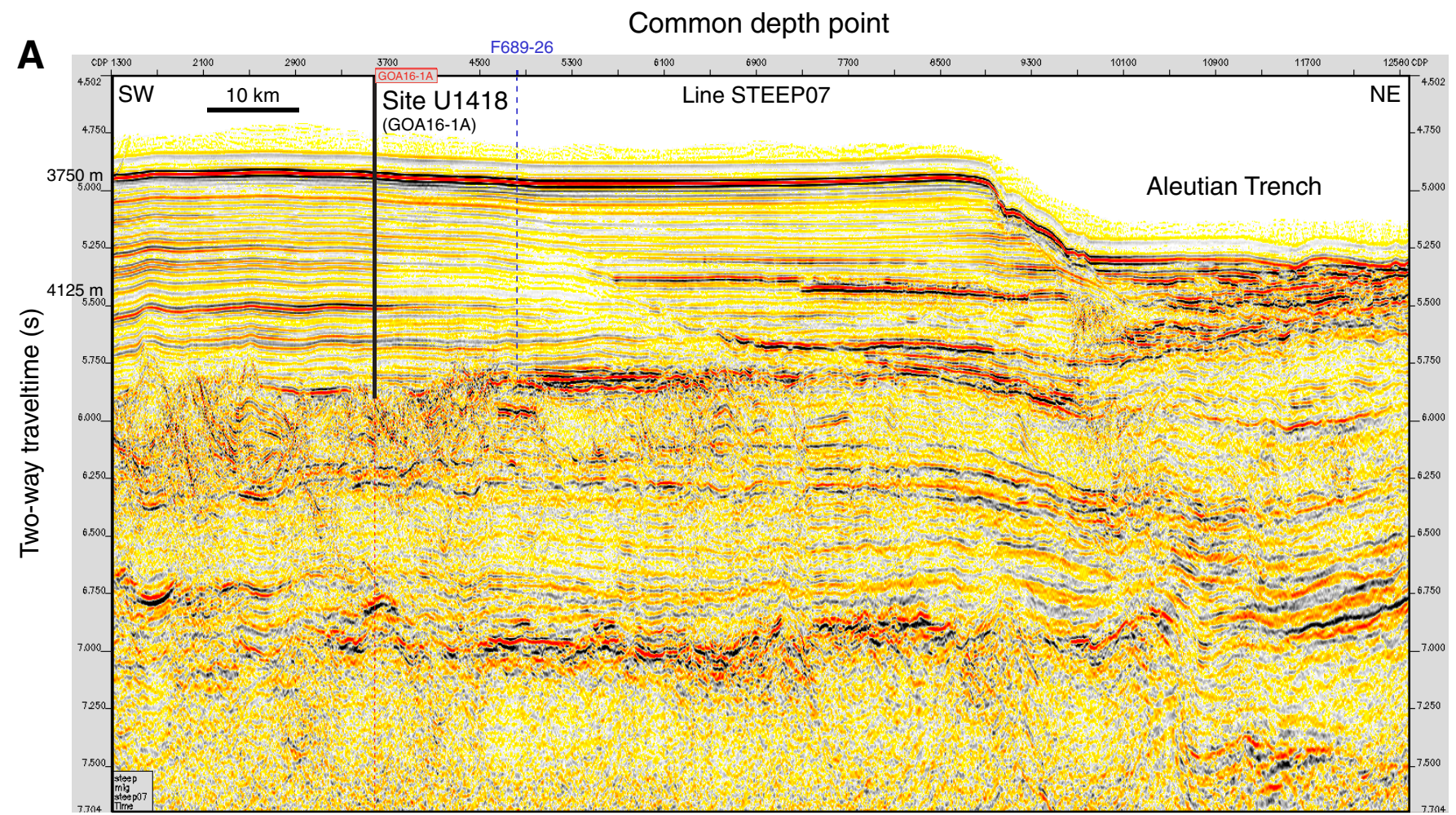

B

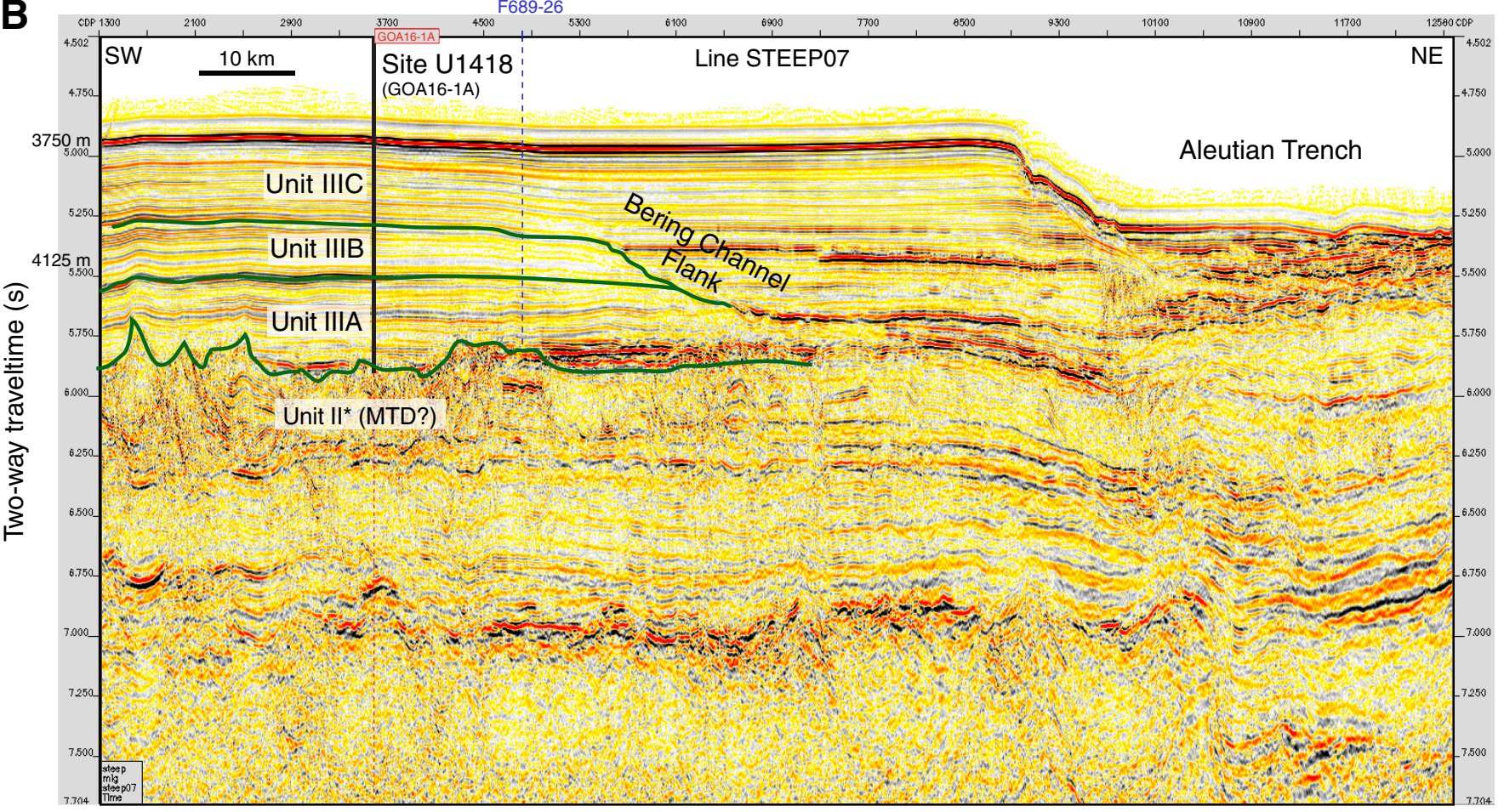


Figure F7. Core recovery, Site U1418.

\section{Site U1418}
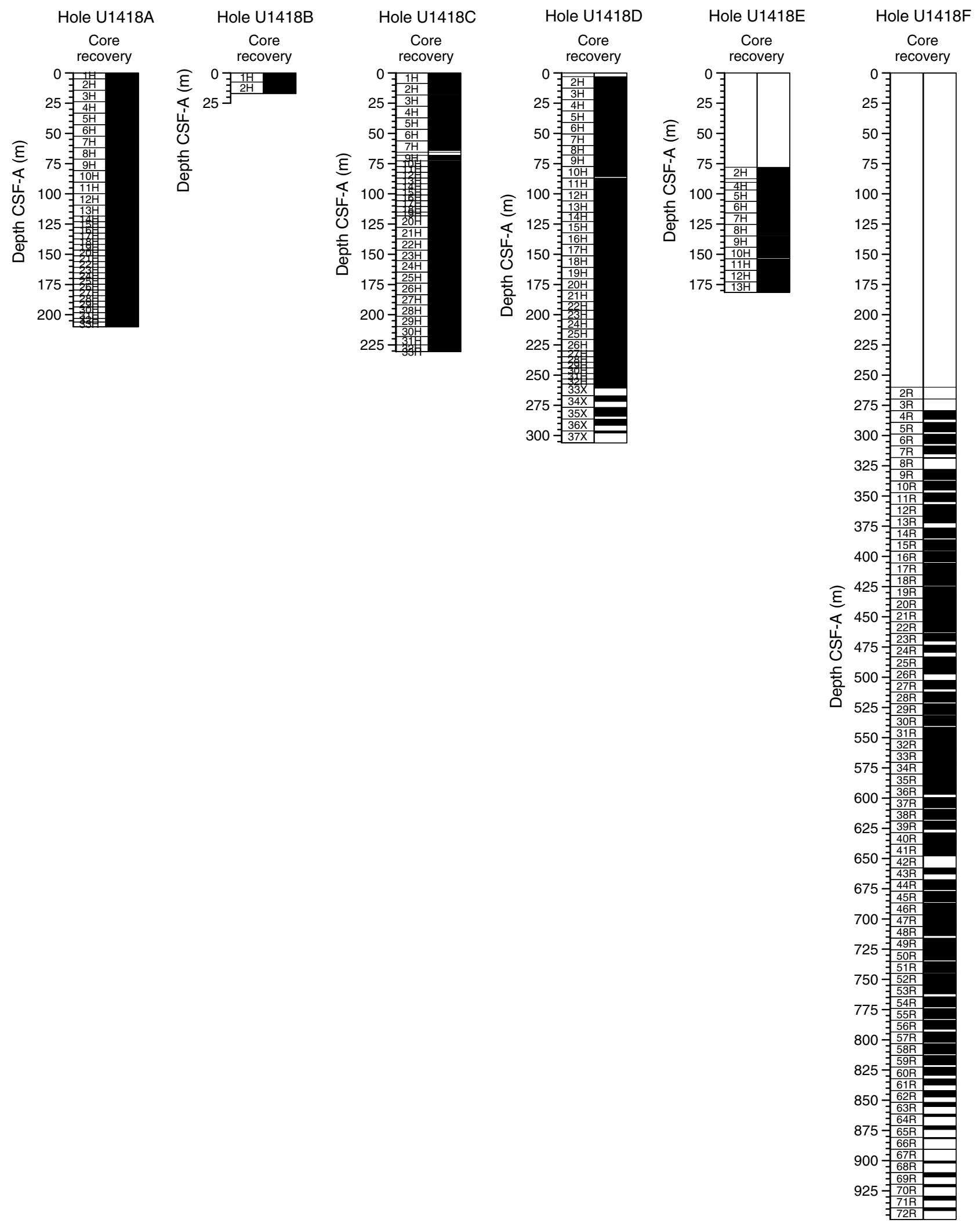
Figure F8. Hole summaries, Site U1418. Volcanic grain abundance: $1=$ trace, $2=$ volcaniclastic bearing, $3=$ volcaniclastic rich, $4=$ ash. GRA = gamma ray attenuation. A. Hole U1418A. (Continued on next five pages.)

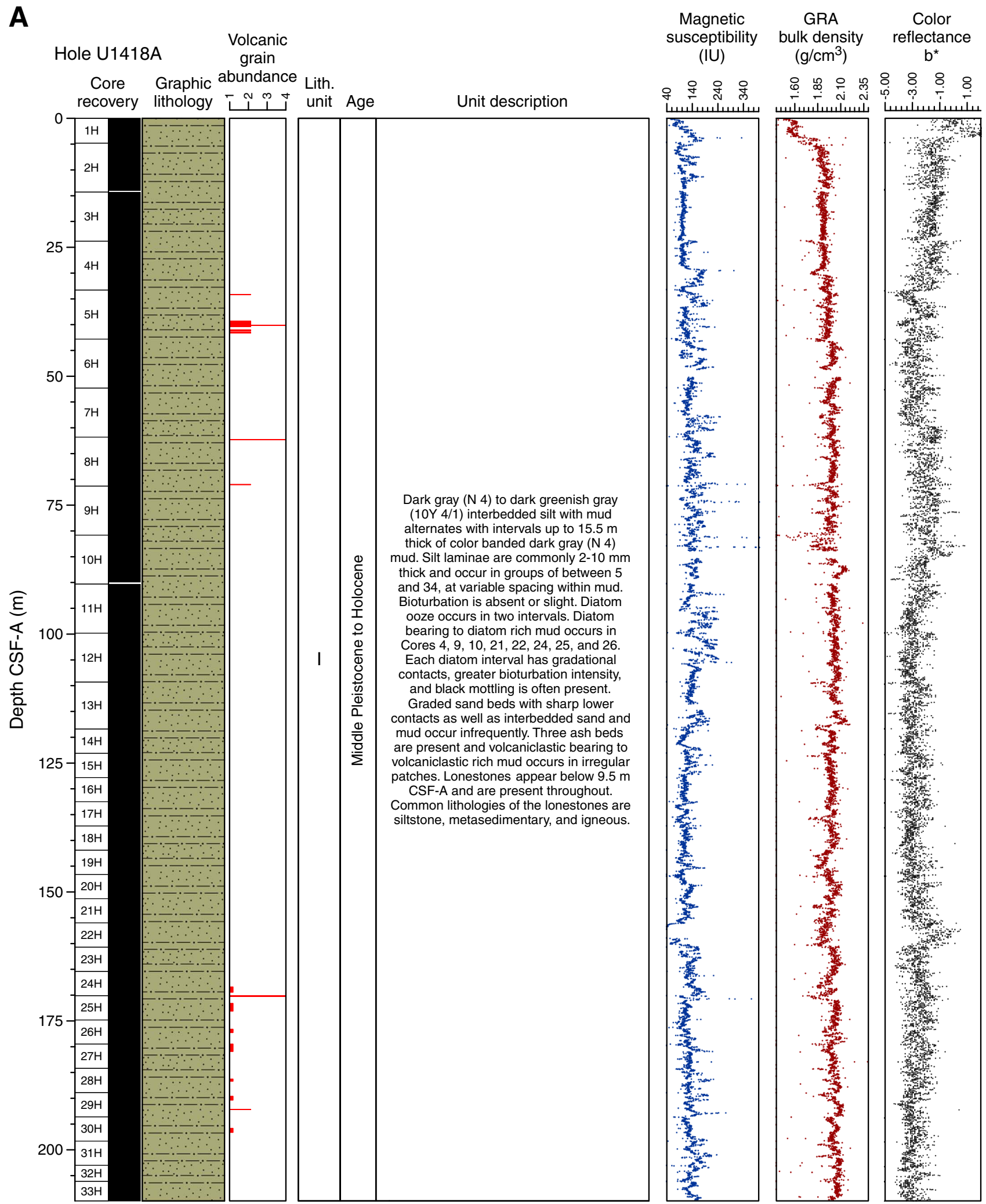


Figure F8 (continued). B. Hole U1418B. (Continued on next page.)

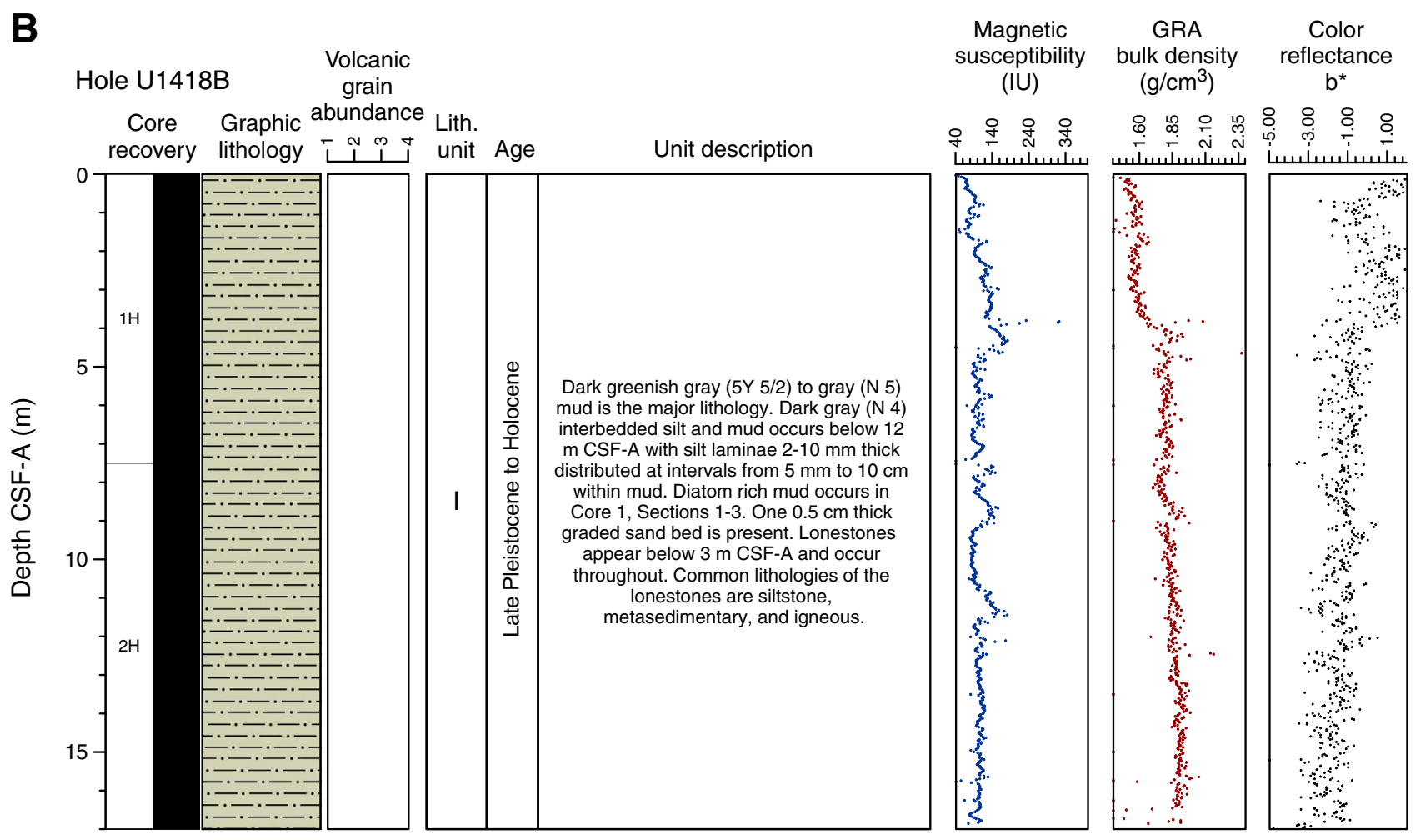


Figure F8 (continued). C. Hole U1418C. (Continued on next page.)
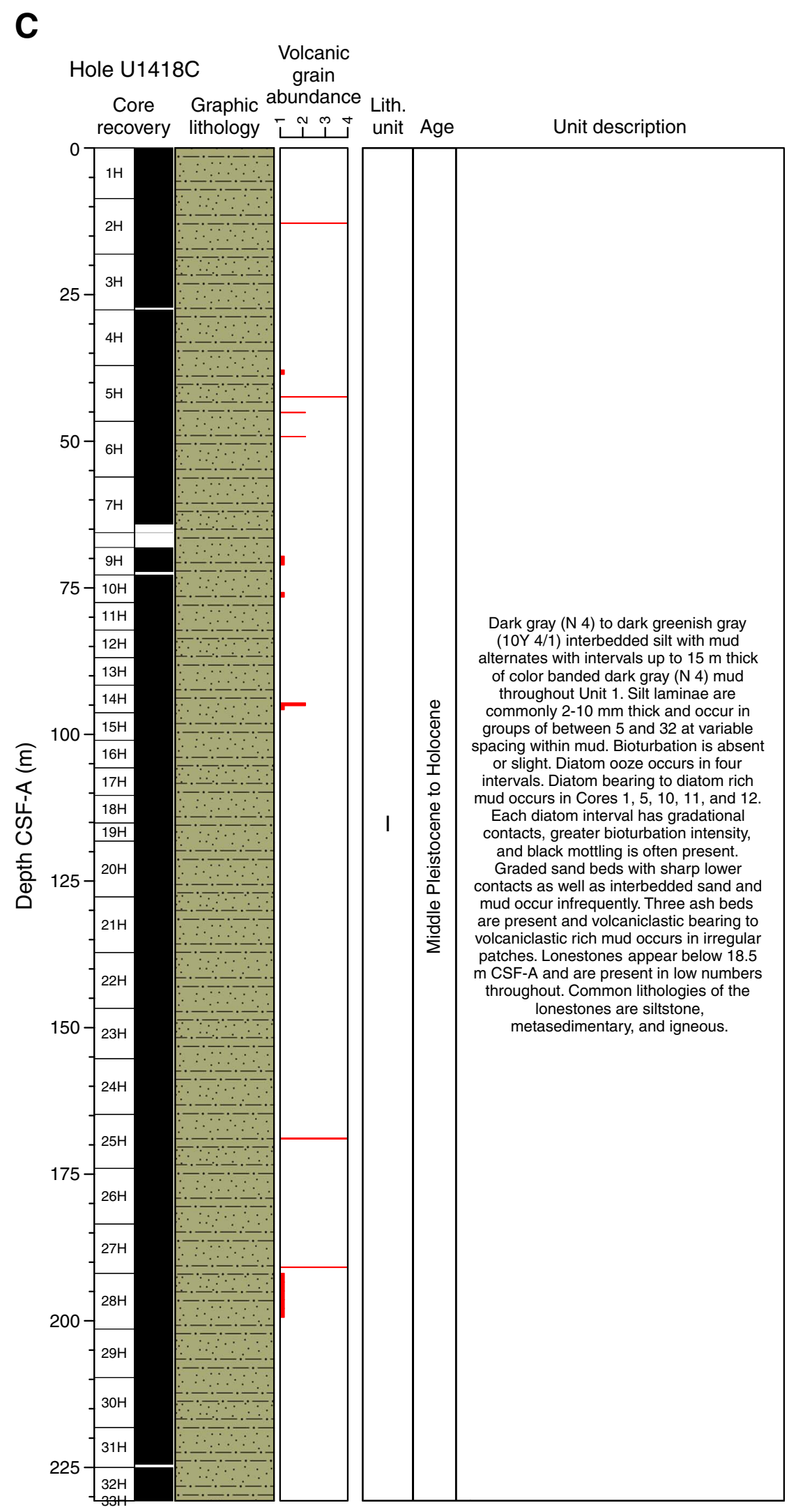
Figure F8 (continued). D. Hole U1418D. (Continued on next page.)

D

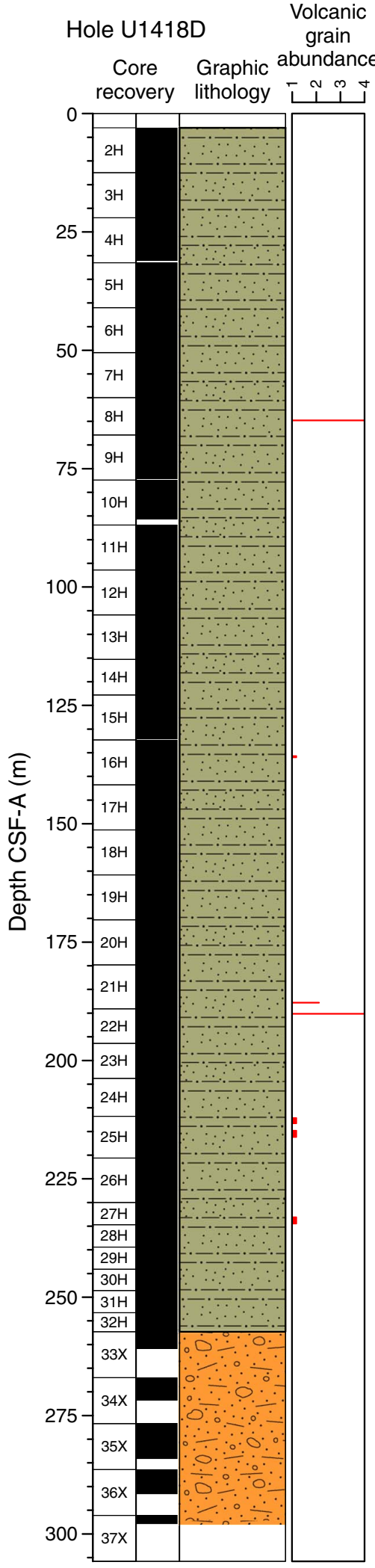
Unit description unit Age

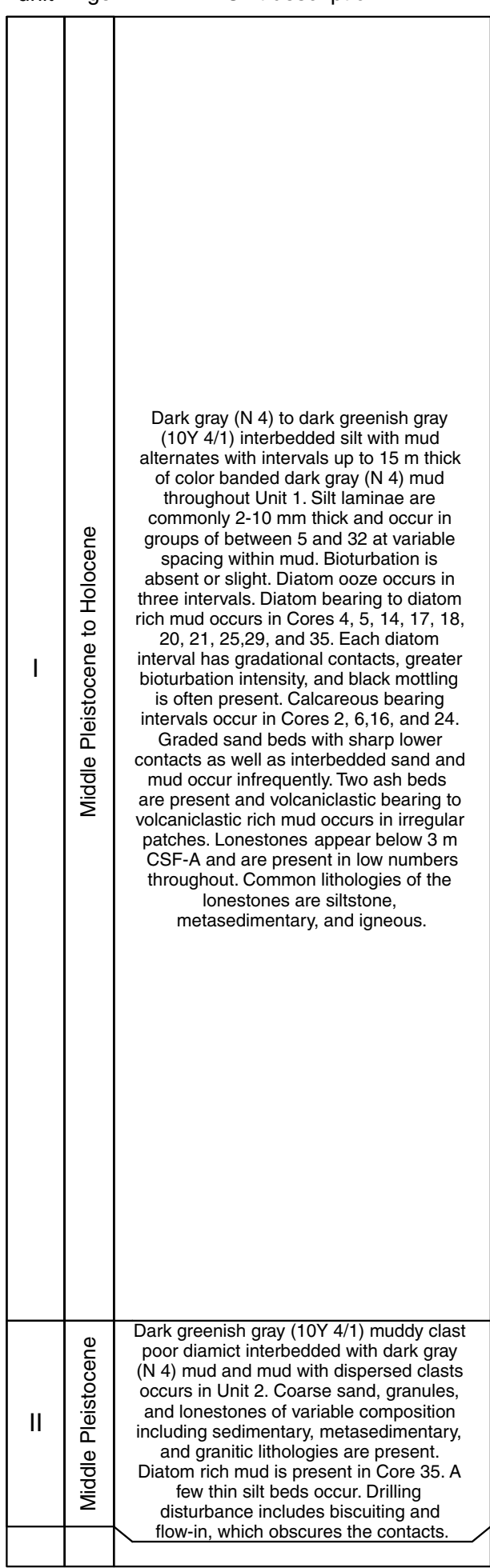

Magnetic susceptibility

(IU)

GRA bulk density

Color reflectance

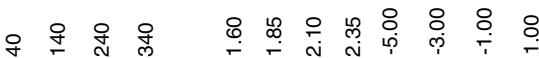
(1)

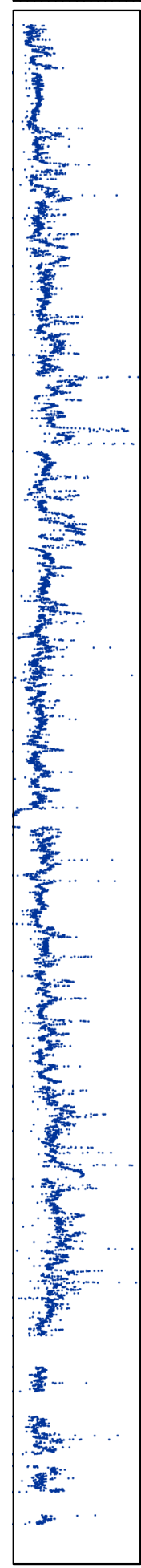
$\left(\mathrm{g} / \mathrm{cm}^{3}\right)$

$b^{*}$ سلسلسسلسا 
Figure F8 (continued). E. Hole U1418E. (Continued on next page.)

E

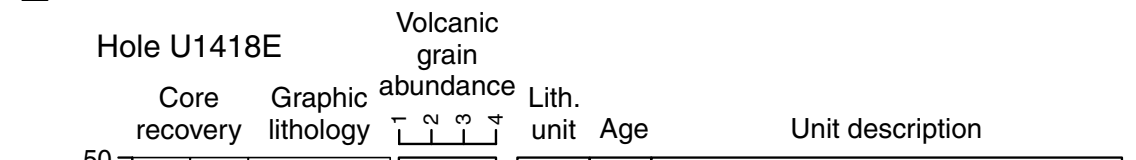

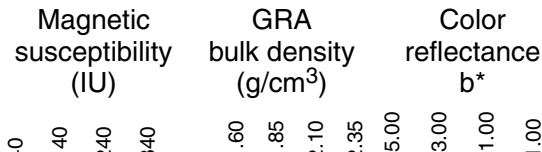

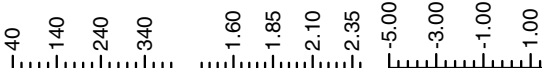
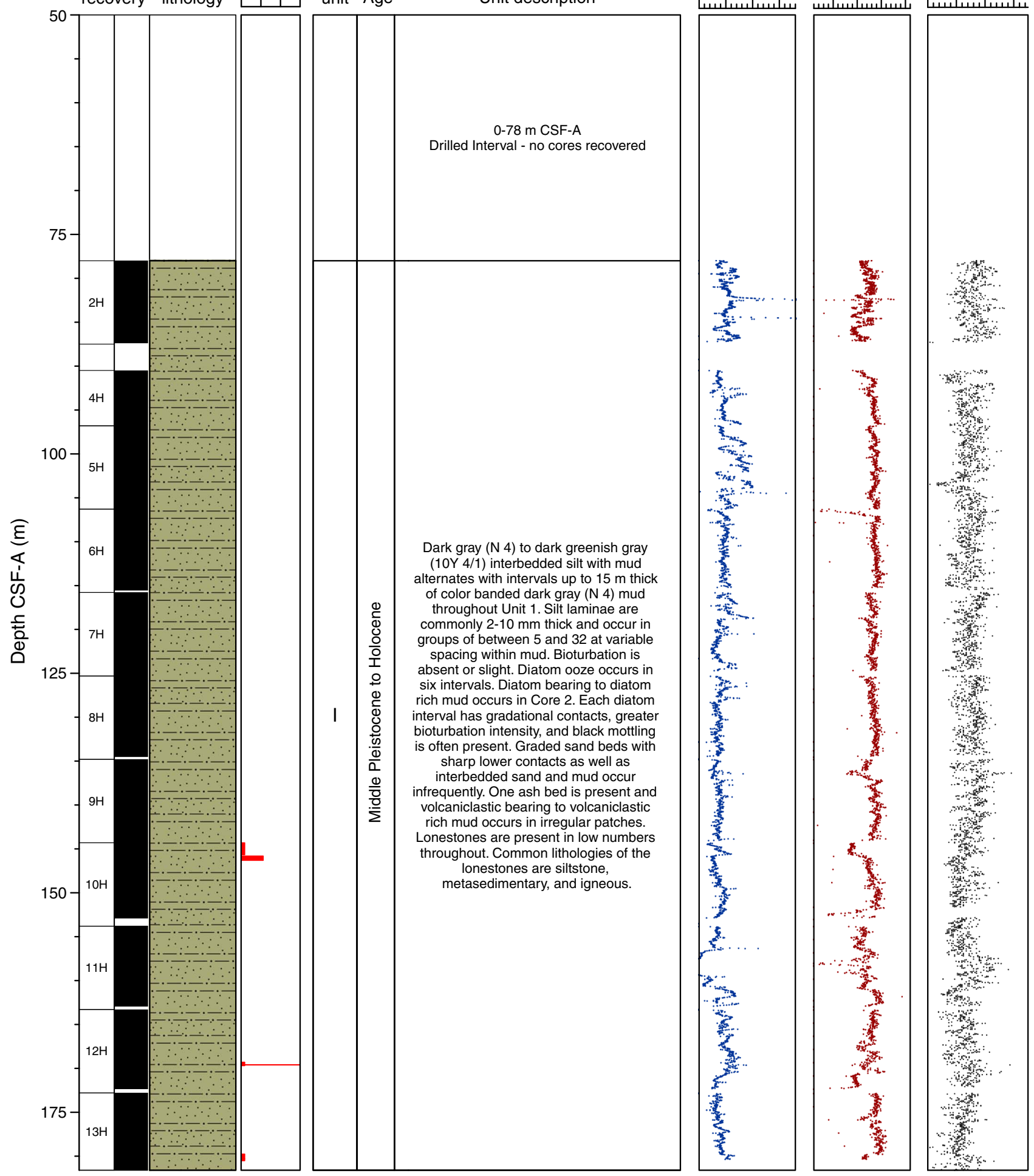
Figure F8 (continued). F. Hole U1418F.

$\mathbf{F}$

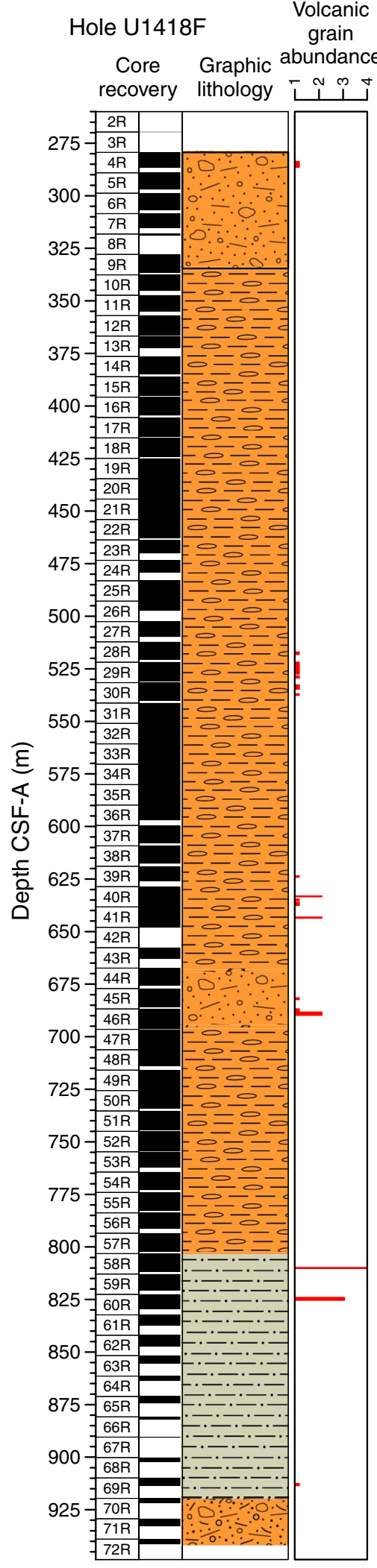

Lith. unit Age

\begin{tabular}{|c|c|c|}
\hline & No recovery \\
\hline IIA & & $\begin{array}{c}\text { Dark gray (N 4) to dark greenish gray (10Y } \\
\text { 4/1) muddy clast-poor diamict interbedded } \\
\text { with dark gray (N 4) mud, and mud with } \\
\text { dispersed clasts. Contacts between beds } \\
\text { appear gradational. Mud is weakly } \\
\text { laminated. Coarse sand, granules, and } \\
\text { lonestones of variable composition occur } \\
\text { within the diamict and mud. }\end{array}$ \\
\hline
\end{tabular}

Dark gray (N 4) to dark greenish gray (10Y 4/1) laminated mud at scales ranging from sub millimeter (a few coarse silt grains) up sub millimeter (a few coarse silt grains) up to $4 \mathrm{~mm}$ thick interbedded with mud with dispersed clasts and clast-poor diamict. Commonly, laminae occur in packages of variable thickness that are bounded with gradational contacts by thin beds of clast-poor diamict forming interbedded mud and diamict facies. Some intervals are calcareous bearing. Volcanic ash occurs as calcareous bearing. Volcanic ash occurs as
burrow fills and in dispersed intervals of burrow fills and in dispersed intervals of
moderate to heavy bioturbation. Lonestones occur throughout.

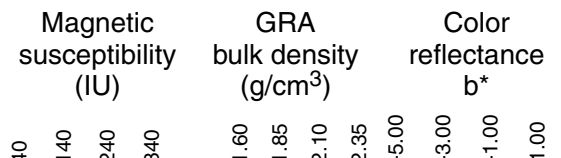

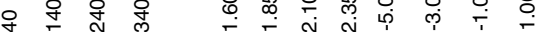

\section{سلسلسلسا ملسلسلسلس ملسلسلسا}

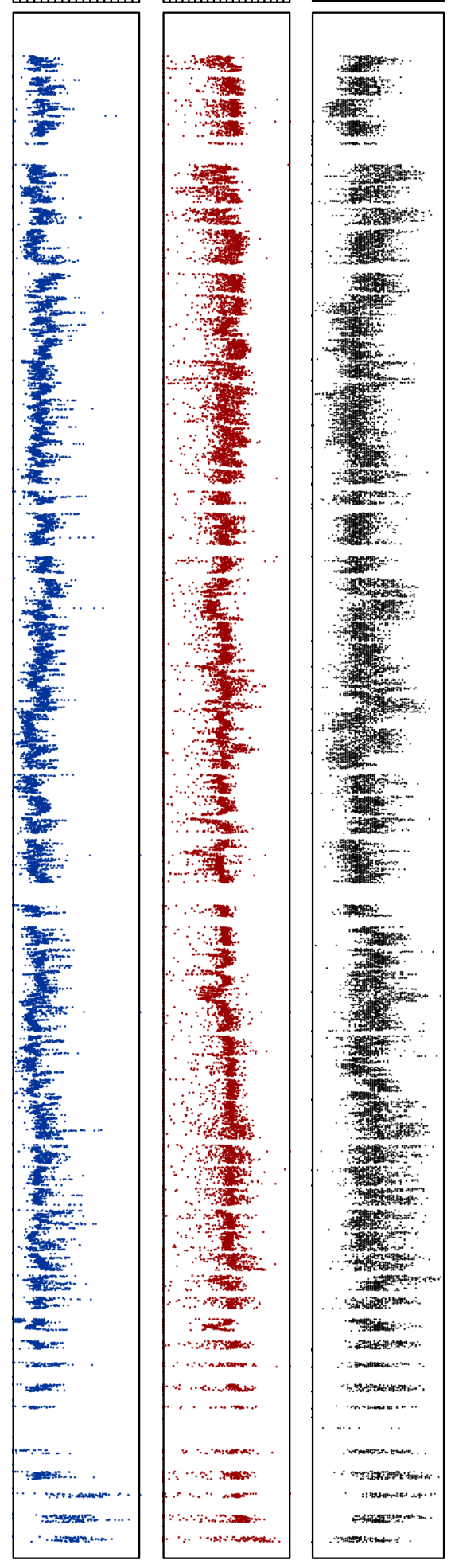


Figure F9. Primary facies, Site U1418. A. Dark gray (N 4) mud without lonestones (Facies F1b; interval 341U1418A-5H-2A, 28-34 cm). B. Laminated mud (Facies F1c; interval 341-U1418F-34R-6A, 20-29 cm). C. Diatom ooze (Facies F5a; interval 341-U1418F-46R-2A, 2-10 cm). D. Interbedded silt and mud (Facies F2b; interval 341U1418C-20H-5A, 91-104 cm). E. Normally graded sand with erosive lower boundary (Facies F3a; interval 341U1418A-27H-1A, 141-145 cm). F. Volcanic ash (arrows) (Facies F6; interval 341-U1418F-58R-5A, 81-90 cm). G. Interlaminated silt and mud (Facies F2b; interval 341-U1418F-63R-3A, 46-52 cm). H. Laminated mud with thin bedded diamict (arrows) (Facies F4d; interval 341-U1418F-30R-3A, 92-102 cm). I. Muddy diamict (Facies 4a; interval 341-U1418D-35X-5A, 84-91 cm). J. Muddy diamict (Facies F4a; interval 341-U1418F-4R-3A, 106$116 \mathrm{~cm}$ ).
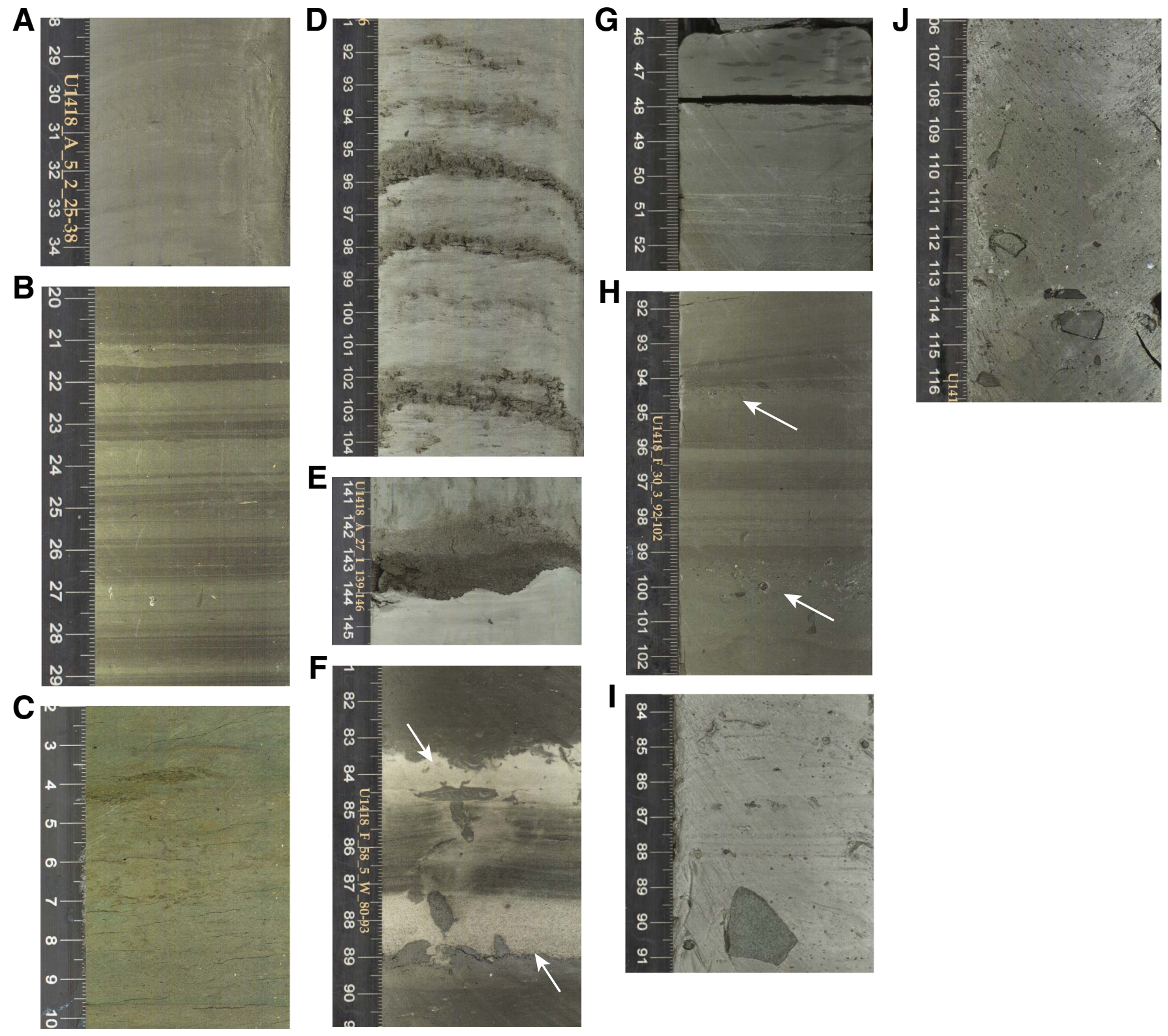
Figure F10. Lonestones and sedimentary and deformational structures, Site U1418. A. Sandstone (interval 341U1418F-23R-3A, 81-87 cm). B. Siltstone (interval 341-U1418D-17H-3A, 109-114 cm). C. Limestone (interval 341-U1418F-6R-4A, 133-136 cm). D. Banded chert (interval 341-U1418F-7R-1A, 2-5 cm). E. Gabbro (interval 341-U1418A-31H-1A, 124-127 cm). F. Granite (interval 341-U1418F-46R-2A, 58-60 cm). G. Gneiss (interval 341-U1418F-38R-1A, 22-24 cm). H. Quartzite (interval 341-U1418B-2H-4A, 89-93 cm). I. Calcite-cemented mud lamina located between 25.3 and $26.0 \mathrm{~cm}$ (interval 341-U1418F-40R-1A, 24-26 cm). J, K. Pyritized burrows; (J) interval 341-U1418F-22R-4A, 65-68 cm, (K) interval 341-U1418F-35R-2A, 23-25 cm. L. Cross-stratification (arrow) (interval 341-U1418F-50R-1A, 133-136 cm). M. Erosional unconformity (interval 341U1418F-52R-4A, 108-112 cm). N. Normal fault (interval 341-U1418F-39R-2A, 131-133 cm). O. Soft-sediment deformation (interval 341-U1418F-50R-2A, 26-38 cm). P. Unconformity at base of slump (interval 341-U1418F50R-3A, 31-35 cm). Q. Normal faults (interval 341-U1418F-50R-1A, 80-85 cm).
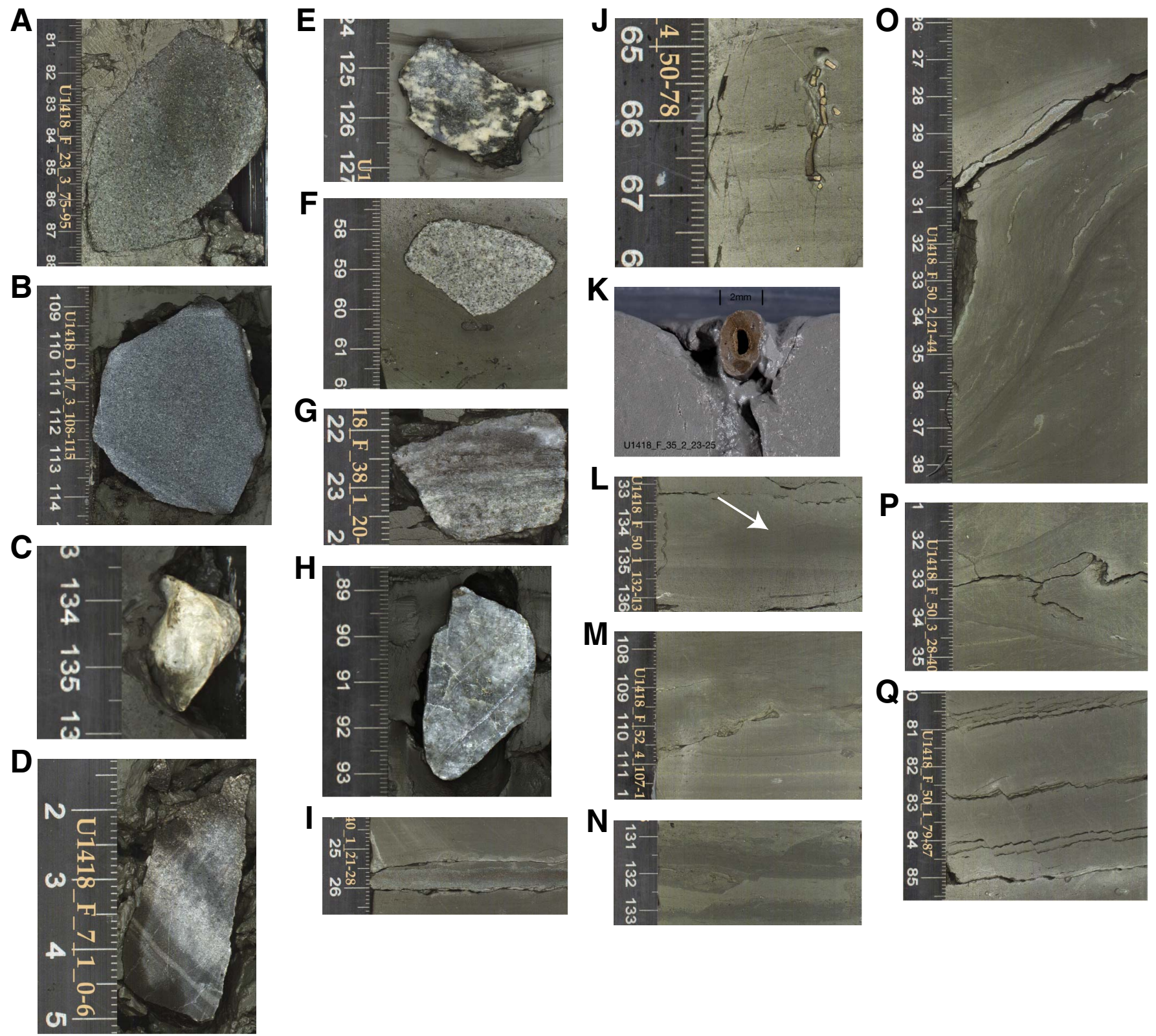
Figure F11. Representative examples of primary lithologies and deformational structures pertaining to Facies 9 (intrastratal contorted mud and diamict) in lithostratigraphic Unit IV, Hole U1418F. The interval between 919 and $941 \mathrm{~m}$ CSF-A in this hole is interpreted as several mass transport deposits. A. Very dark greenish gray (10Y 3/1) mud mixed with very dark gray (N 3) muddy diamict with abundant clasts (interval 341-U1418F-71R-2A, 9-33 cm). B. Muddy diamict with abundant clasts (interval 341-U1418F-72R-1A, 72-87 cm). C. Slurry deposit of mud clasts in deformed mud (interval 341-U1418F-70R-1A, 20-31 cm). D. Micro-brecciated mud (interval 341-U1418F-70R-2A, 16-21 cm). E. Deformed laminated mud (interval 341-U1418F-71R-1A, 46-54 cm). F. Normal faults marked with white arrows (interval 341-U1418F-70R-2A, 71-77 cm). G. Close-up of set of very small $(0.5 \mathrm{~cm})$ normal faults in mud (interval 341-U1418F-70R-2A, 63-65 cm).
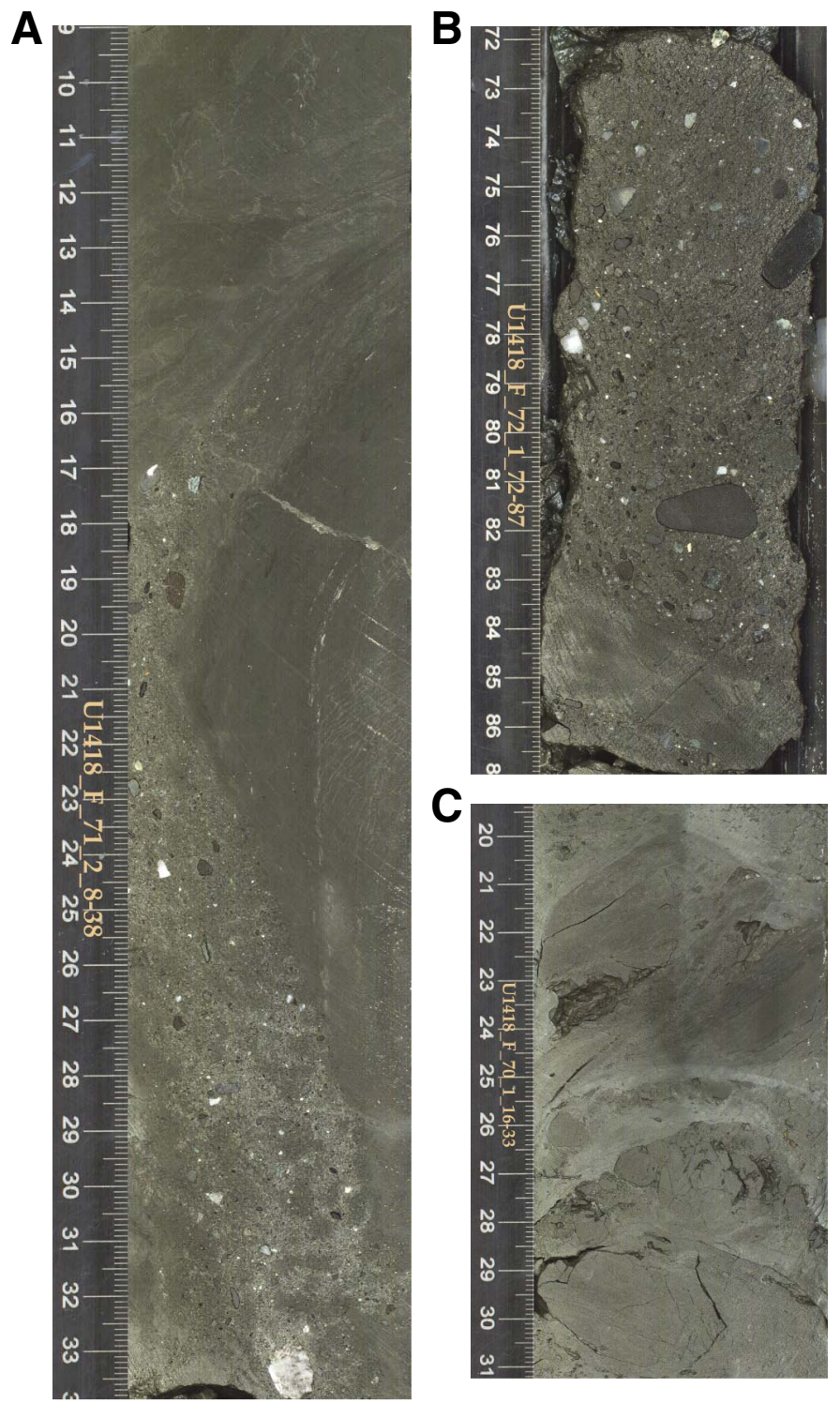

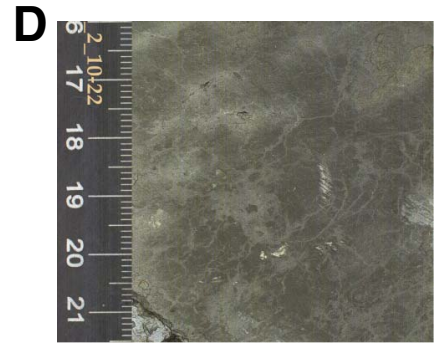

$\mathrm{E}$
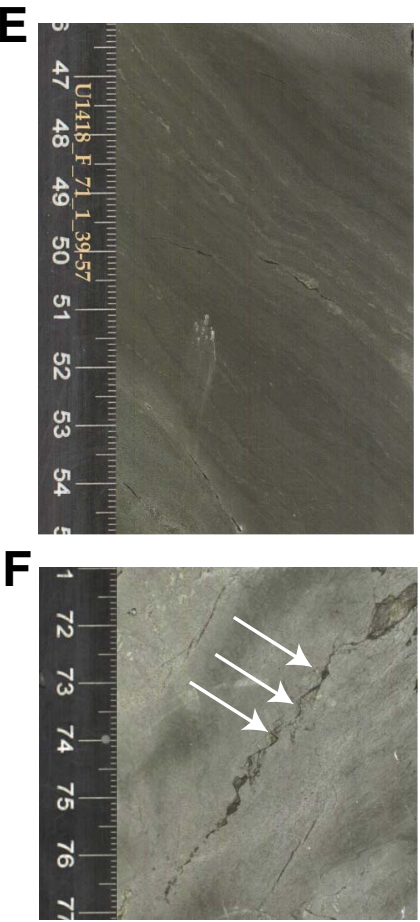

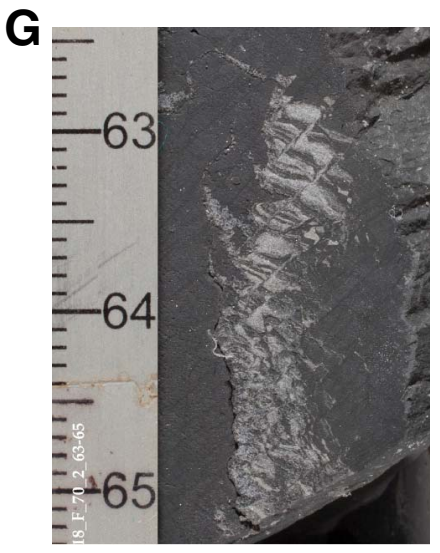


Figure F12. Schematic diagram of lithostratigraphic units and major lithologies, Site U1418. Clasts per meter column shows number of lonestones $>2 \mathrm{~mm}$ in diameter per meter of section described. For more on the bioturbation intensity index, see the "Methods" chapter (Jaeger et al., 2014a). With the exception of lonestone counts, presence of laminations, and bioturbation index values, downcore profiles represent the occurrence of a described lithologic feature. Data from Holes U1418A and U1418C-U1418F were combined to produce these plots. The early/Middle Pleistocene boundary is placed at the midpoint depth of the Matuyama-Brunhes transition, which occurs close to, but slightly shallower than, the Subunit IIB-IIC transition. Because of the high abundance of clasts in Subunit IIA through Unit IV, individual clasts ( $>2 \mathrm{~mm})$ were not counted. Horizontal dashed lines denote unit boundaries.

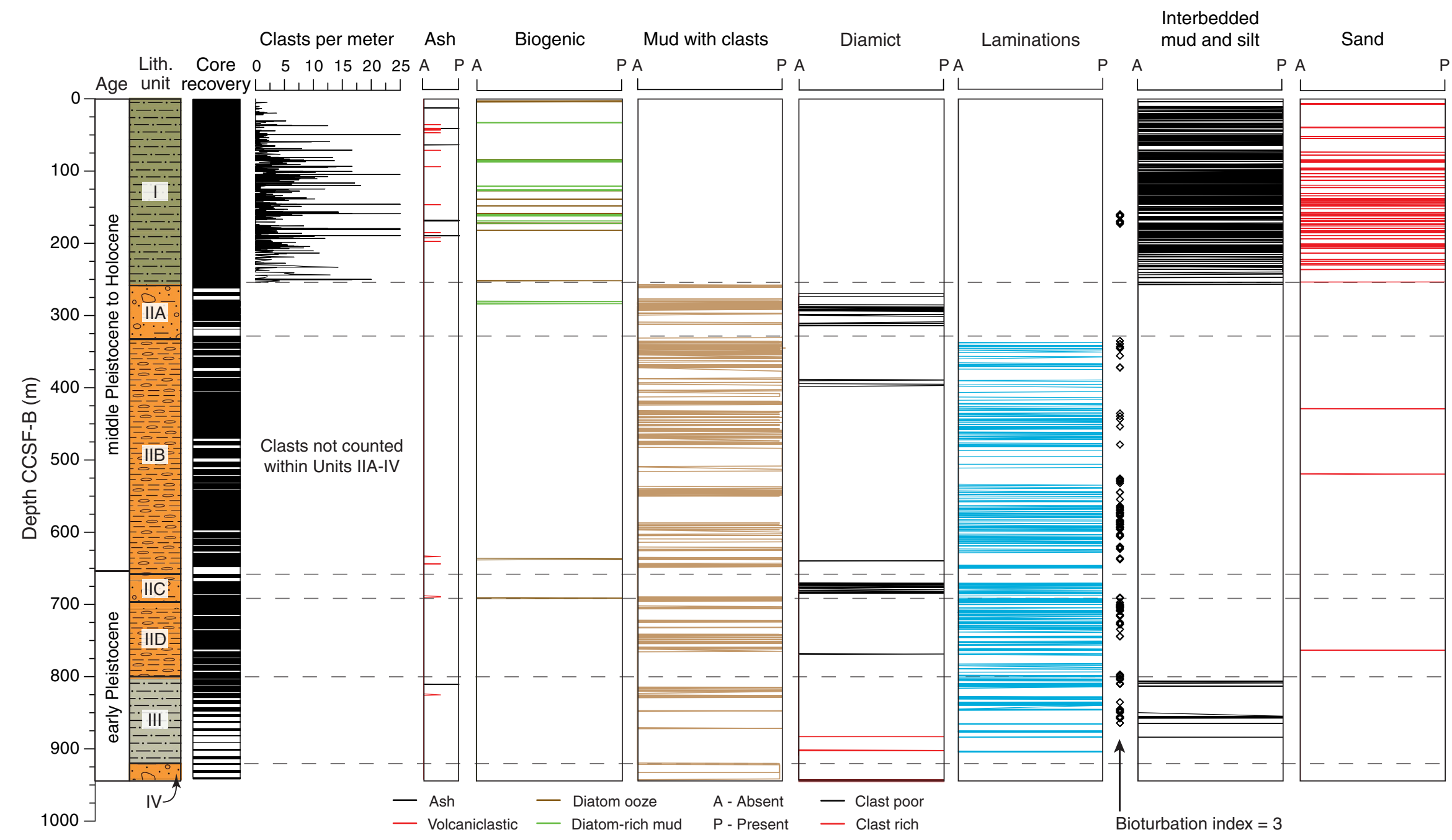


Figure F13. Ternary diagram showing average abundance of the main lithology types of clasts in Holes U1418A-U1418F and the average for Site U1418.

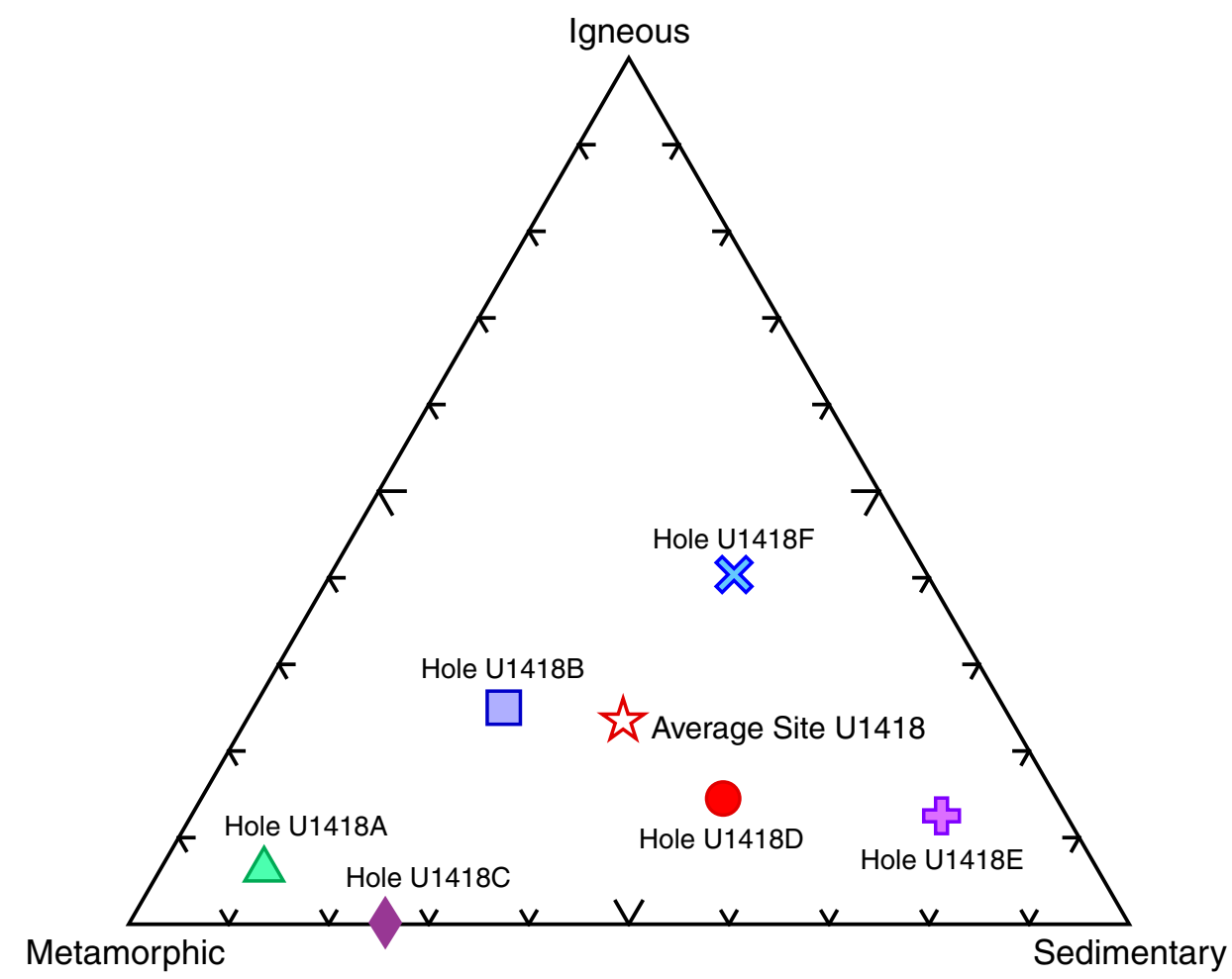


Figure F14. A. X-ray powder diffraction patterns, Holes U1418A and U1418C-U1418F. Bulk mineralogy is nearly constant downhole, although minor changes in intensity occur for various peaks. (Continued on next page.)

A

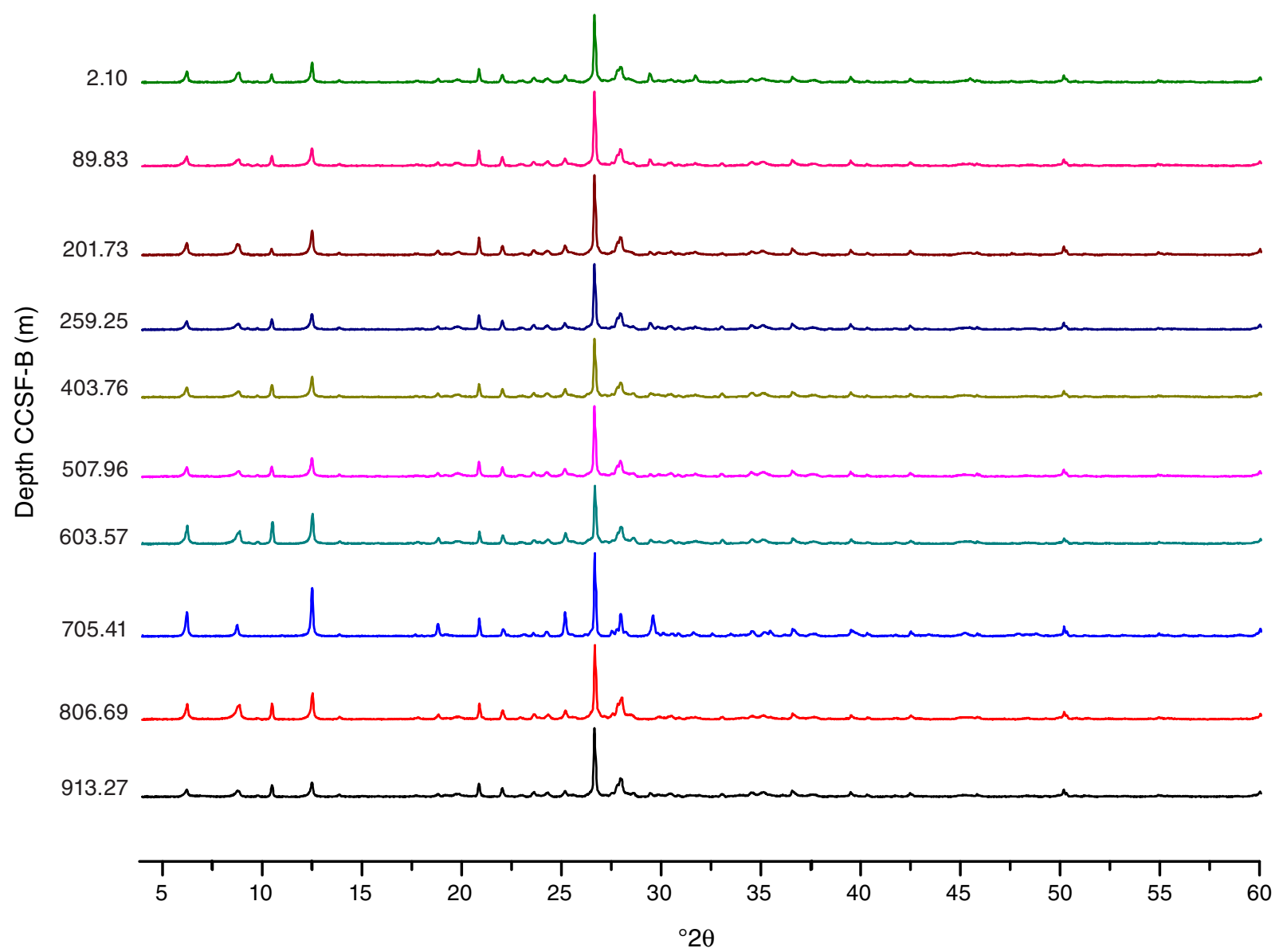


Figure F14 (continued). B. Comparative X-ray diffraction patterns from $4^{\circ}$ to $24^{\circ} 2 \theta$, Site U1418. Scans show downhole samples before (left) and after (right) glycolation treatment.

B
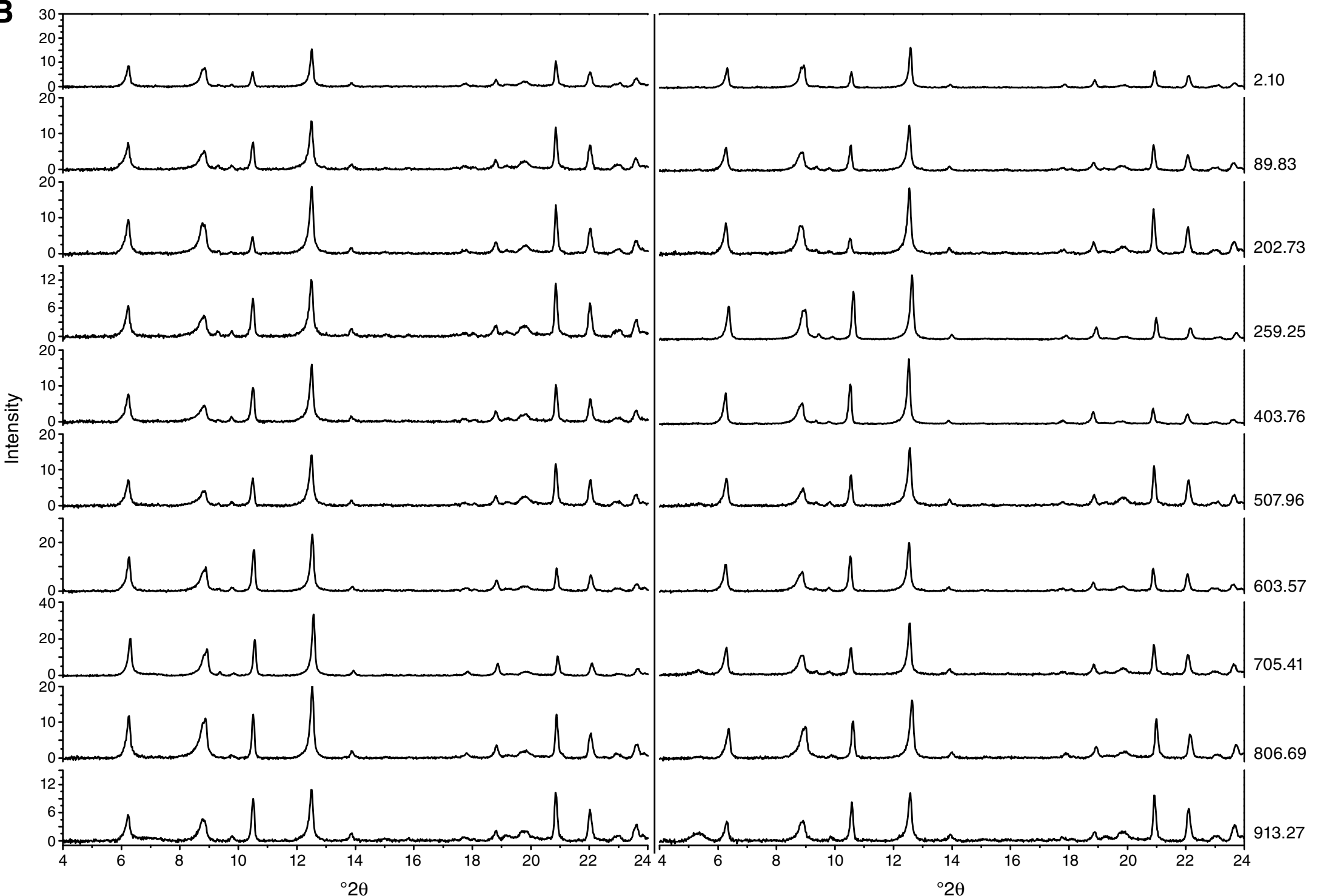
Figure F15. Abundance and preservation of diatoms, radiolarians, and planktonic and benthic foraminifers, Site U1418. Black bars in the Biozone columns show the uncertainty in the depths of the observed biohorizons. The number within the black bars indicates the age of the biozone boundary. JM = Jaramillo. NPD = Neogene North Pacific Diatom zone of Yanagisawa and Akiba (1998), CM = California margin. Abundance: $\mathrm{D}=$ dominant, $\mathrm{A}=$ abundant, $\mathrm{C}=$ common, $\mathrm{F}=\mathrm{few}, \mathrm{R}=$ rare, $\mathrm{P}=$ present, $\mathrm{B}=$ barren. Preservation: $\mathrm{VG}=$ very good, $\mathrm{G}$ = good, $\mathrm{M}=$ moderate, $\mathrm{P}=$ poor .

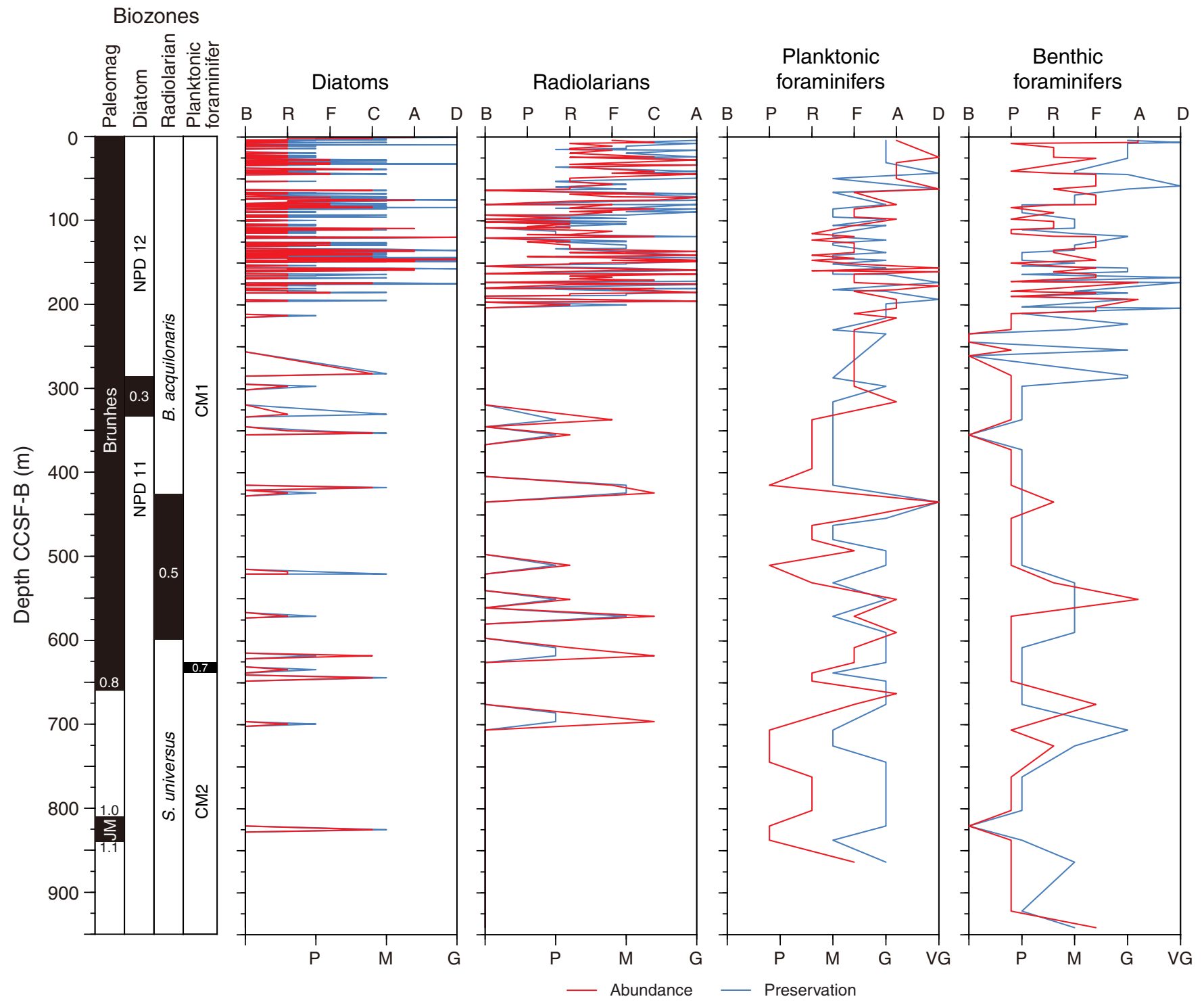


Figure F16. Rank abundance of paleoenvironmental indicators, Site U1418. Black bars in the Biozone columns show the uncertainty in the depths of the observed biohorizons. The number within the black bars indicates the age of the biozone boundary. JM = Jaramillo. NPD = Neogene North Pacific Diatom zone of Yanagisawa and Akiba (1998), $\mathrm{CM}=$ California margin. Abundance: $\mathrm{A}=\mathrm{abundant}, \mathrm{C}=\mathrm{common}, \mathrm{F}=\mathrm{few}, \mathrm{R}=\mathrm{rare}, \mathrm{P}=$ present, $\mathrm{X}=$ present.

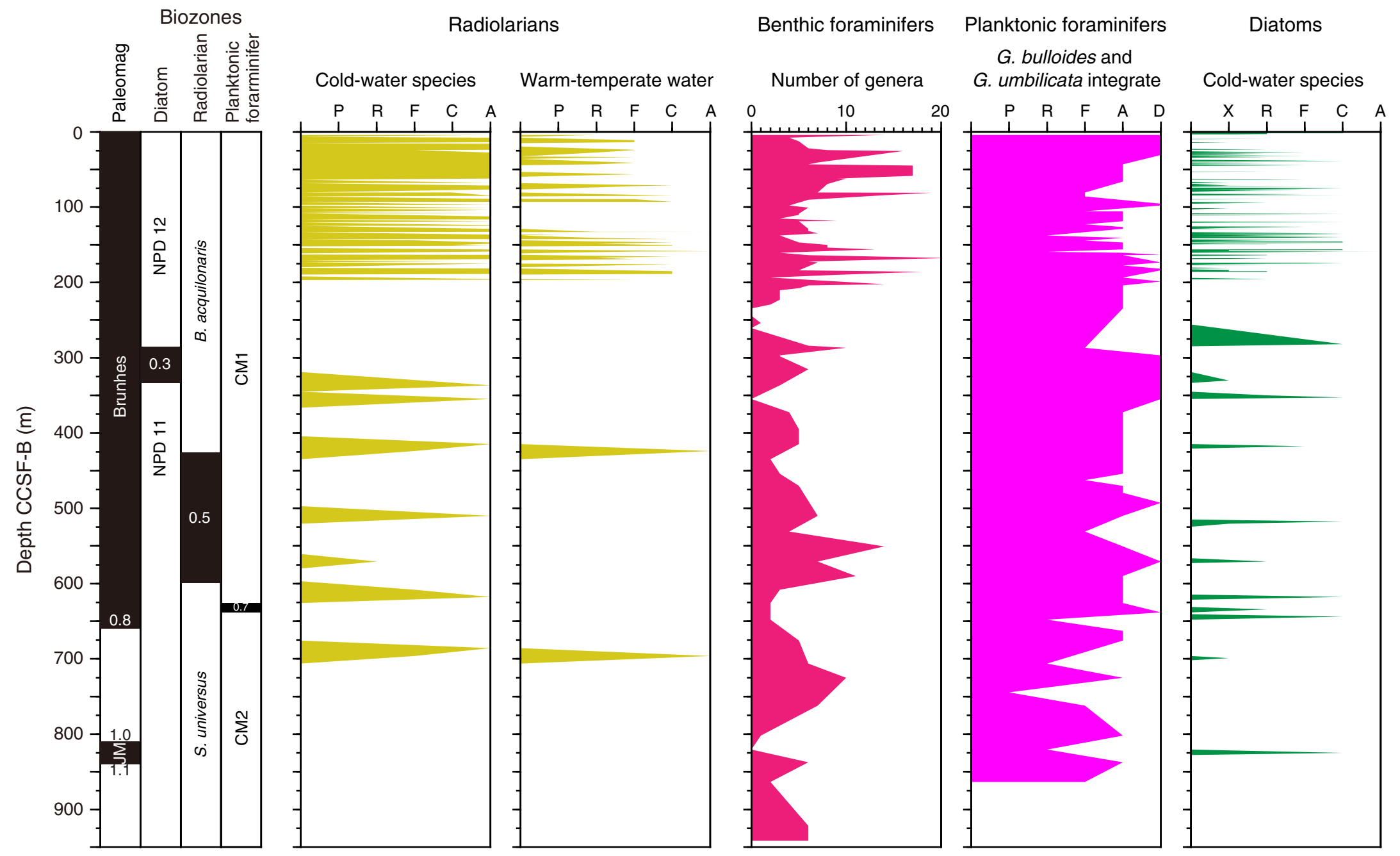


Figure F17. Rank abundance of planktonic foraminifer datum species and neritic and coastal diatoms, Site U1418. Planktonic foraminifers: Neoglolobigerina inglei and Neoglolobigerina kagaensis. See text for details. Black bars in the Biozone columns show the uncertainty in the depths of the observed biohorizons. The number within the black bars indicates the age of the biozone boundary. JM = Jaramillo. NPD = Neogene North Pacific Diatom zone of Yanagisawa and Akiba (1998), $\mathrm{CM}=$ California margin. Abundance: $\mathrm{D}=$ dominant, $\mathrm{A}=$ abundant, $\mathrm{C}=$ common, $\mathrm{F}=$ few, $\mathrm{R}=$ rare, $\mathrm{P}=$ present, $\mathrm{X}=$ present.

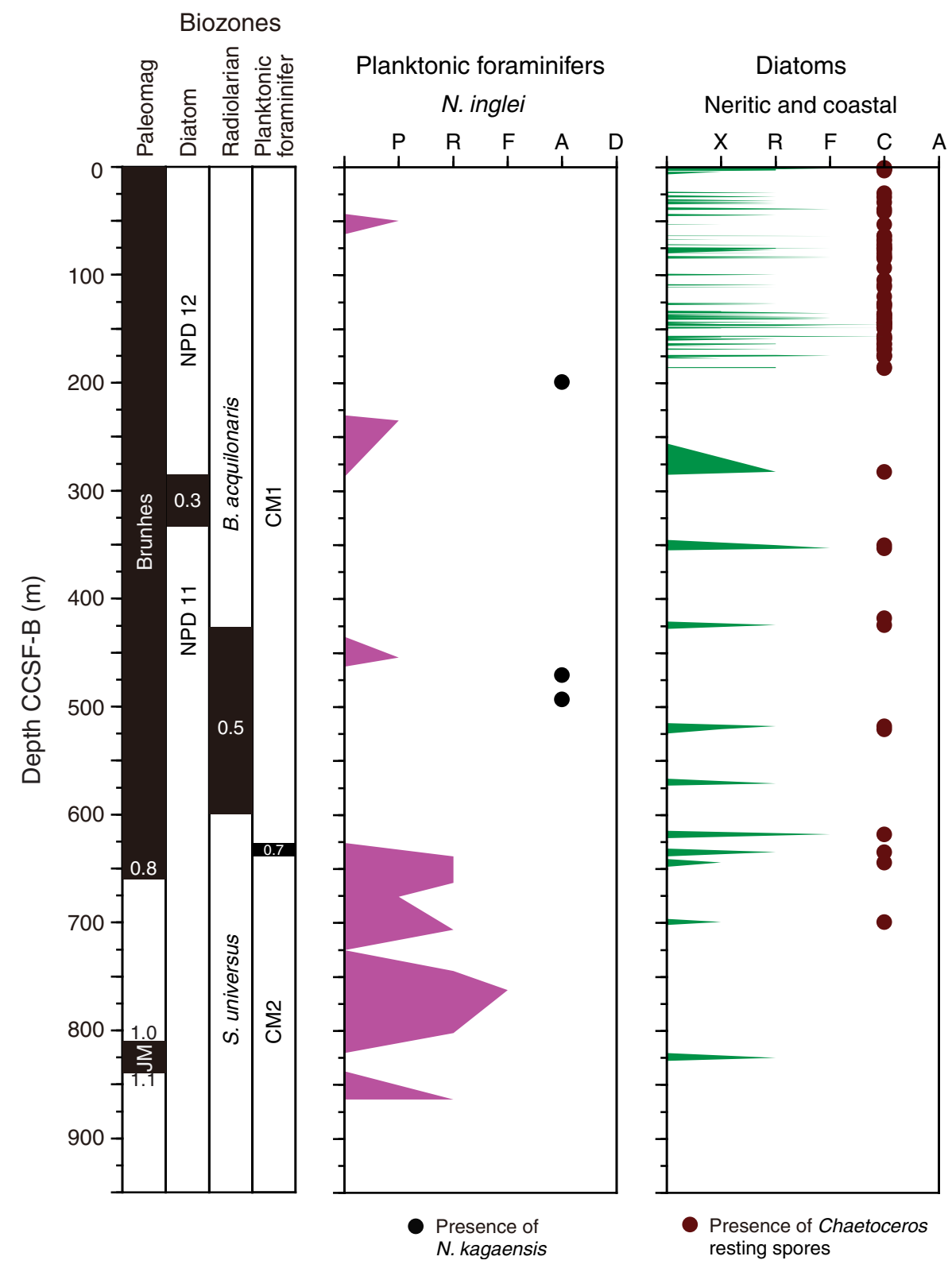


Figure F18. Rank abundance of paleoenvironmental indicators, Site U1418. Radiolarians are Cycladophora davisiana, a coastal upwelling species in the pelagic northeast Pacific (Welling and Pisias, 1993) and Spongopyle osculosa, a cold deepwater species (Kamikuri et al., 2007). Buliminids are low-oxygen indicators. Black bars in the Biozone columns show the uncertainty in the depths of the observed biohorizons. The number within the black bars indicates the age of the biozone boundary. JM = Jaramillo. NPD = Neogene North Pacific Diatom zone of Yanagisawa and Akiba (1998), $C M=$ California margin. Abundance: $D=$ dominant, $A=$ abundant, $C=$ common, $F=$ few, $R=$ rare, $P=$ present, $X=$ present.

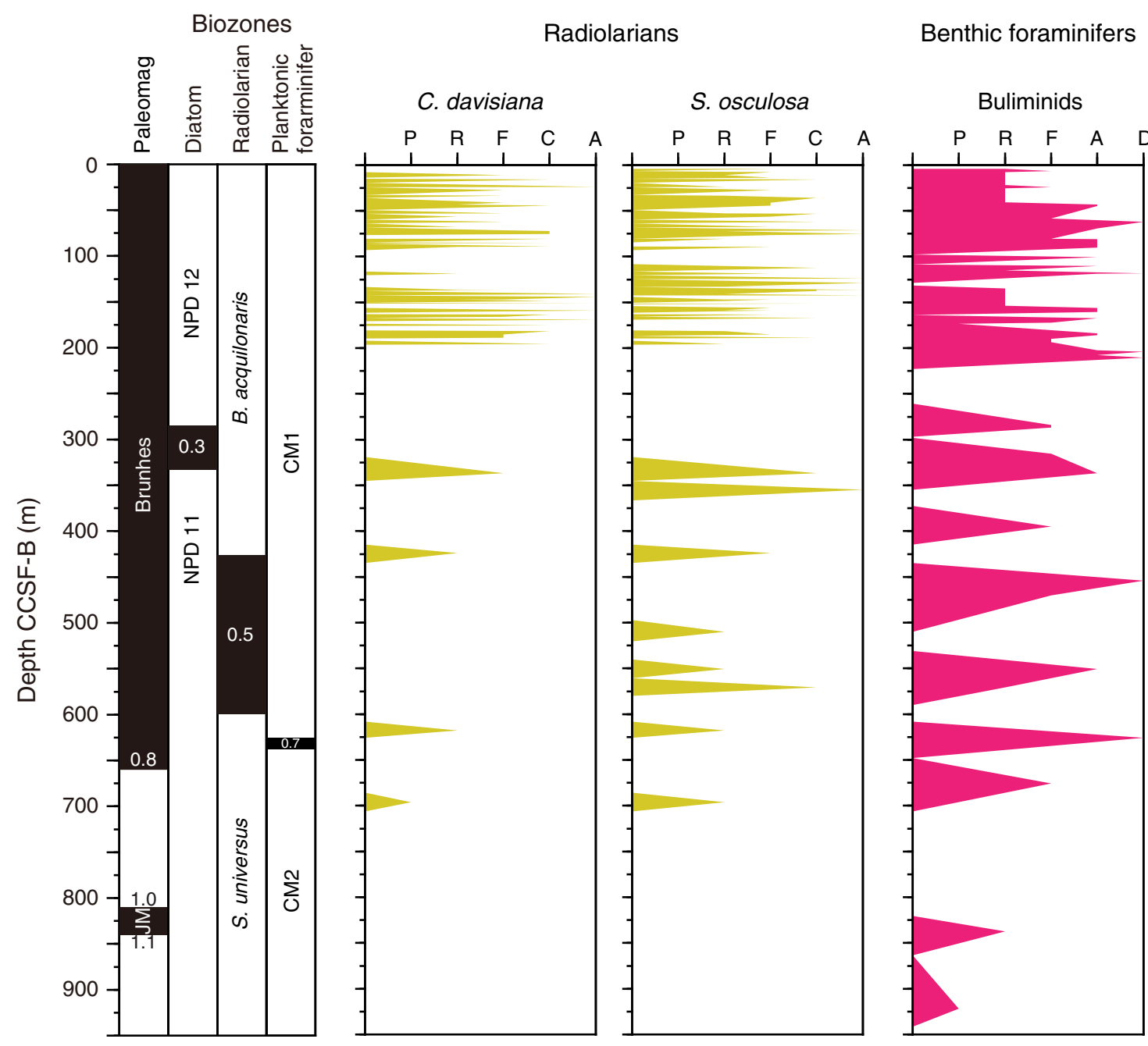

Benthic foraminifers

\section{Buliminids}

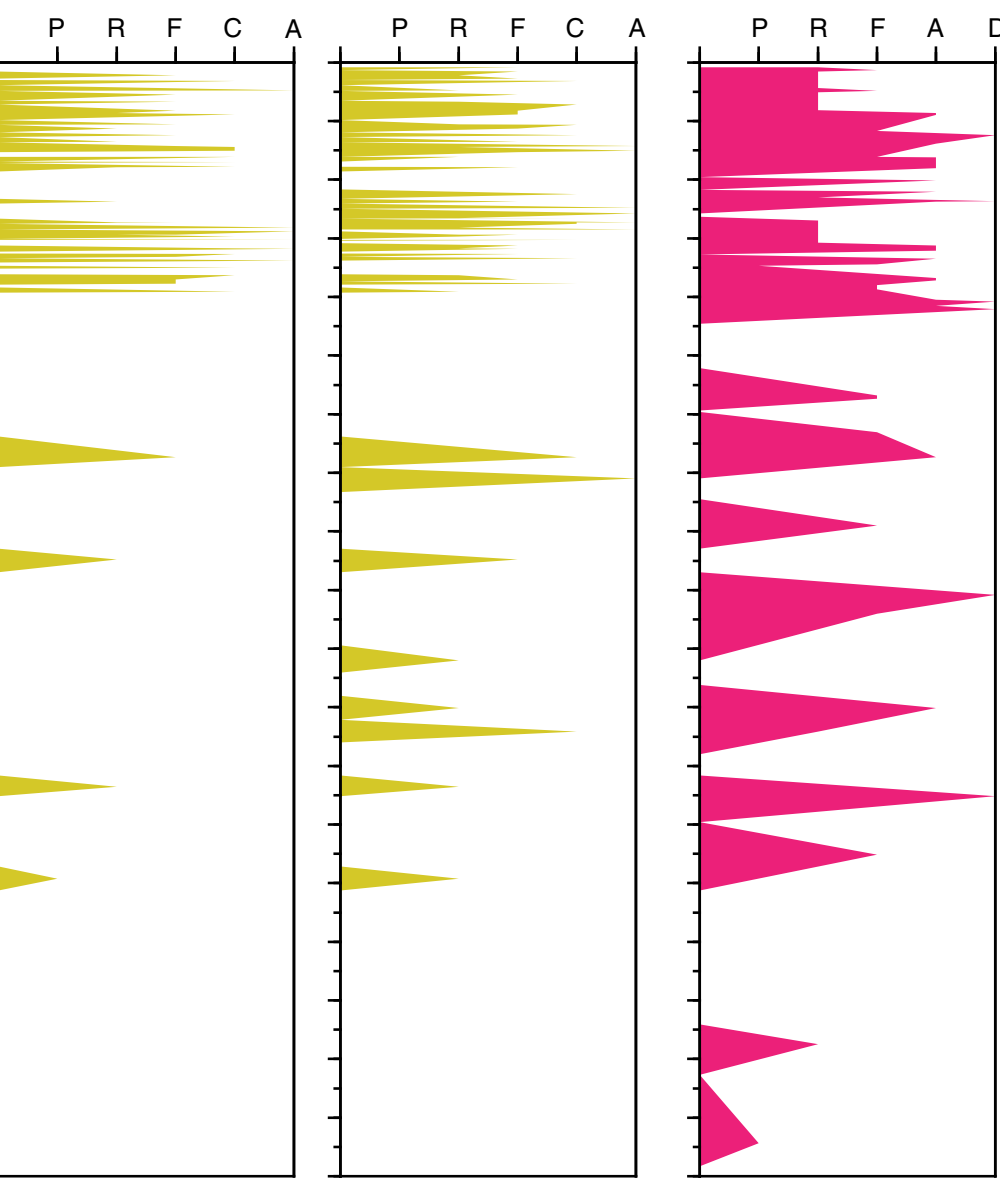

Diatoms

Sea ice related species

Warm- and temperate-

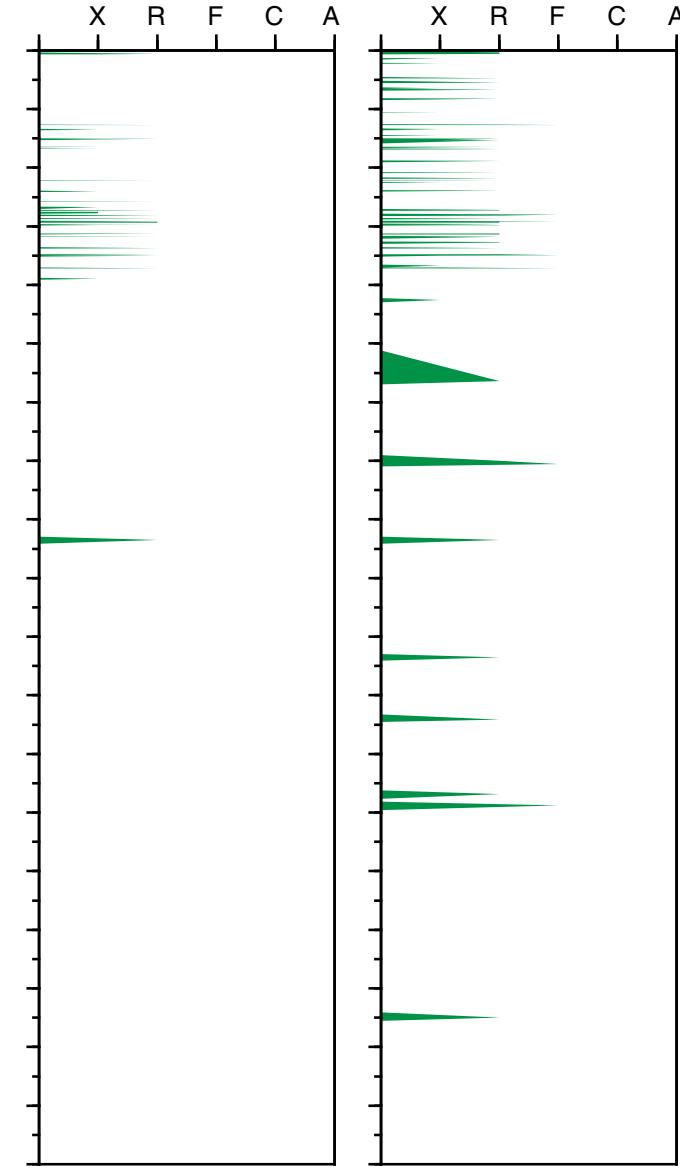


Figure F19. Diatom, planktonic foraminifer, and radiolarian datum species, Site U1418. Primary datums that define biozones and secondary datums are illustrated. Black bars in the Biozone columns show the uncertainty in the depths of the observed biohorizons. The number within the black bars indicates the age of the biozone boundary. JM = Jaramillo. NPD = Neogene North Pacific Diatom zone of Yanagisawa and Akiba (1998), CM = California margin. $\mathrm{LO}=$ last occurrence.

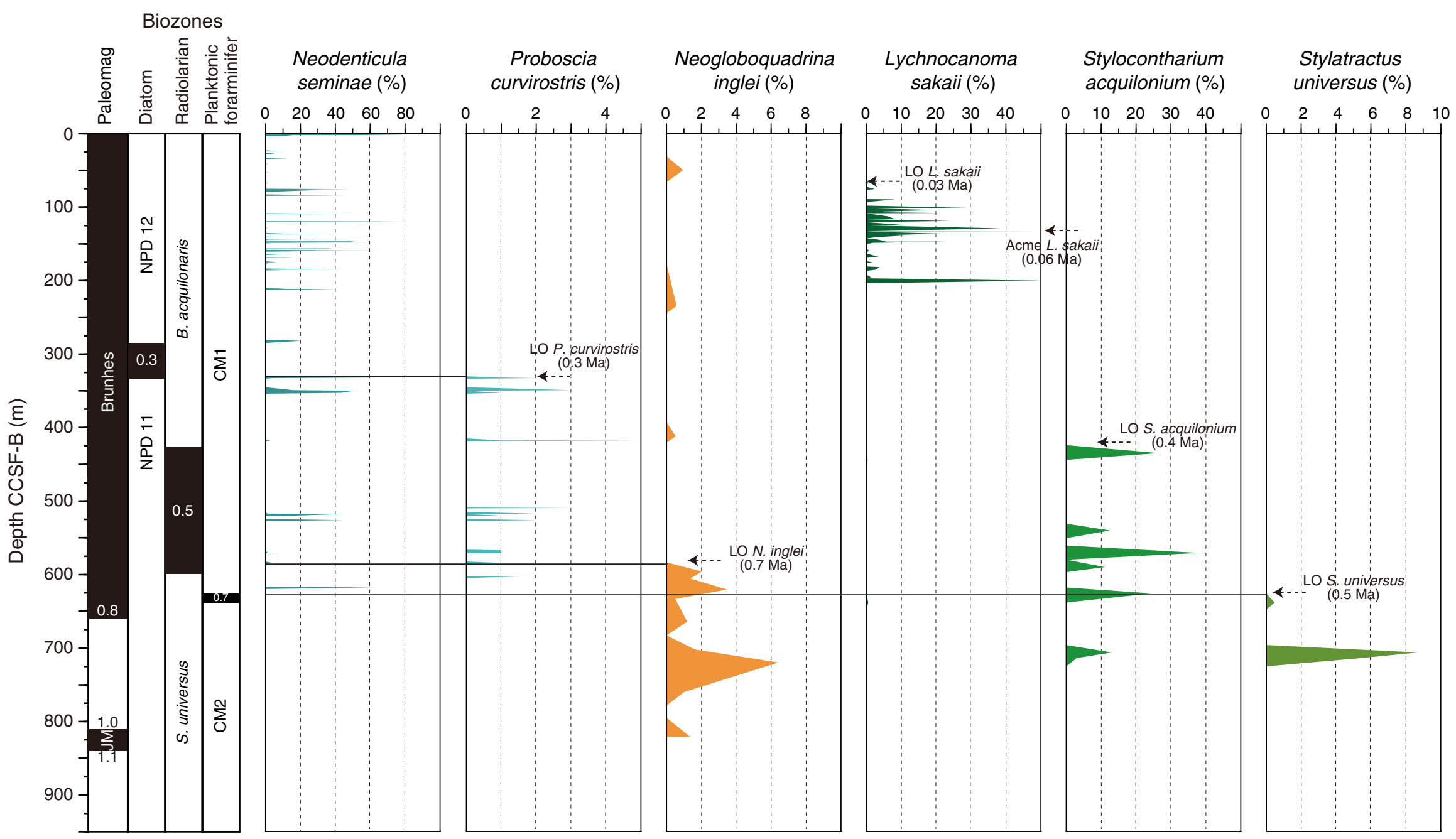


Figure F20. Intensity measured before and after 10 and $20 \mathrm{mT}$ AF demagnetization and declination and inclination measured after $20 \mathrm{mT}$ peak AF demagnetization for Hole U1418F. Polarity interpretation and correlation to the geomagnetic polarity timescale (GPTS) on the geological timescale 2012 (Hilgen et al., 2012) is shown and developed in the text (see "Paleomagnetism"). The deepest three cores (341-U1418-70R through 72R) containing a mass transport deposit are not included, though intensities are similar to those of the sediment above.

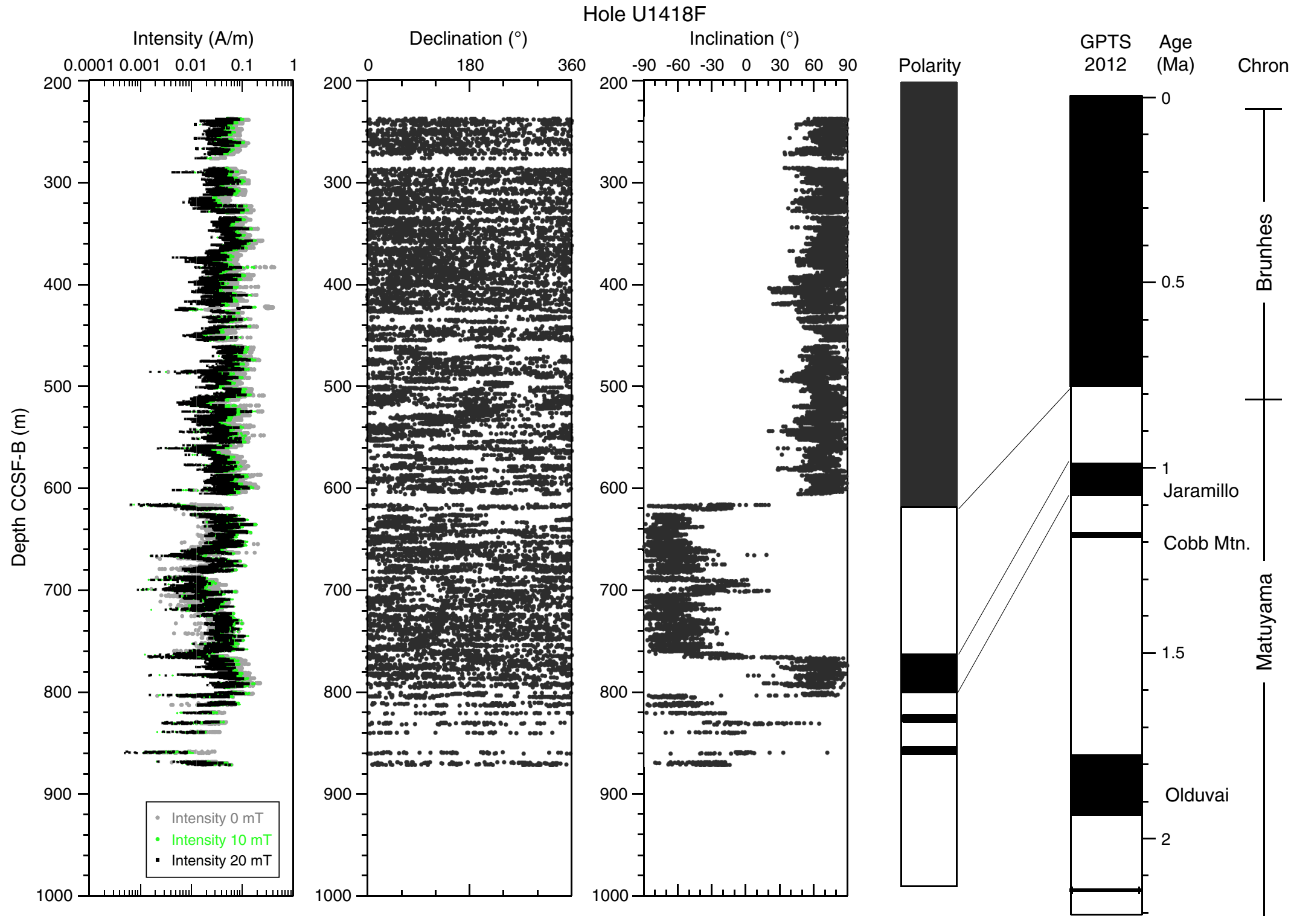


Figure F21. Magnetic susceptibility data for the interval of the continuous splice in Holes U1418A-U1418E and the splice record. Gray boxes = intervals used to construct the splice; numbers indicate core numbers from each hole used in the splice. Dashed vertical lines with question marks indicate intervals where tie points should be treated with caution (see text for details). Asterisks = intervals in which magnetic susceptibility data could not be run on the WRMSL because of core-liner patches; in these cases, magnetic susceptibility is available from STMSL or SHMSL runs. A. 0-50 m CCSF-A. (Continued on next four pages.)

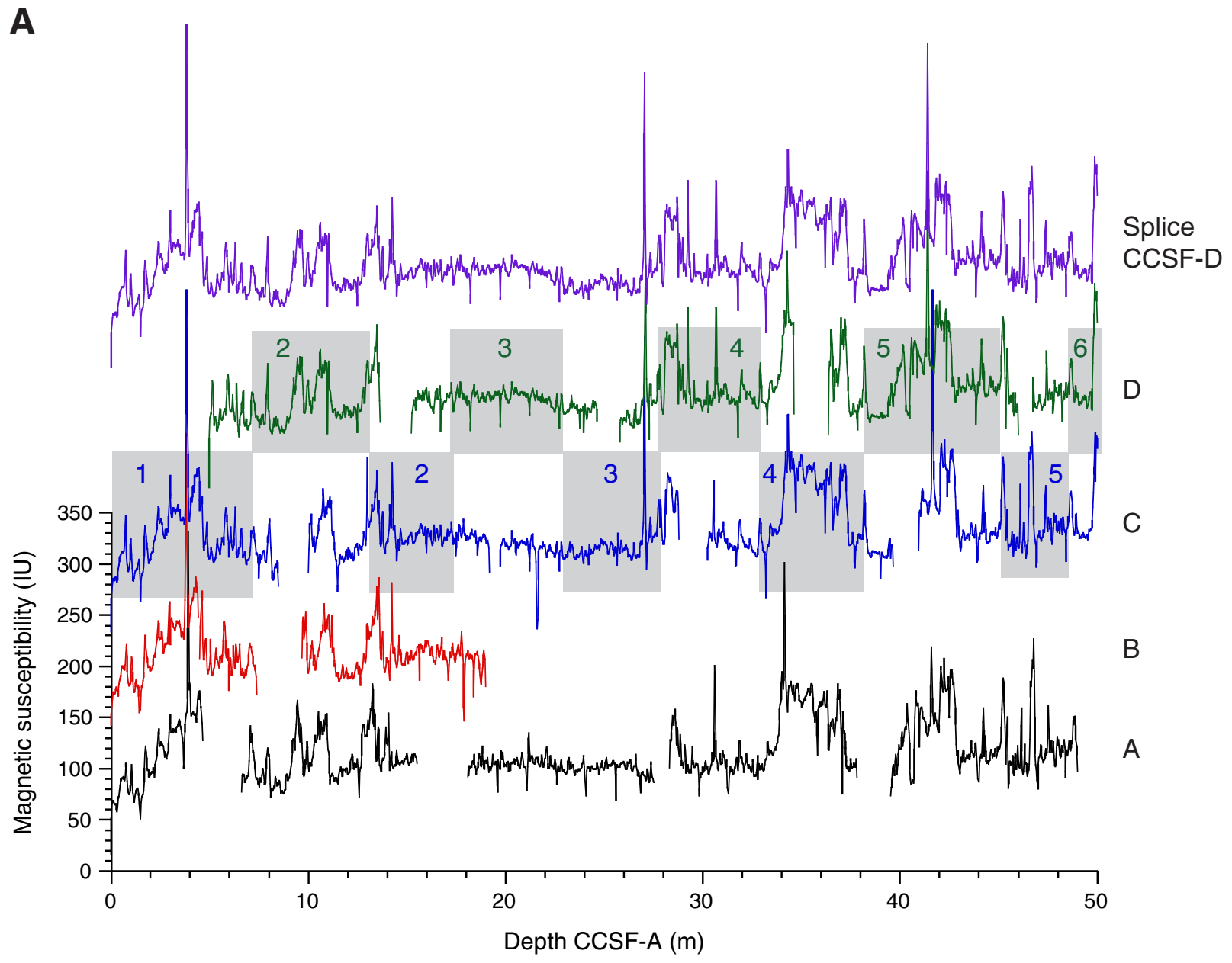


Figure F21 (continued). B. 50-100 m CCSF-A. (Continued on next page.)

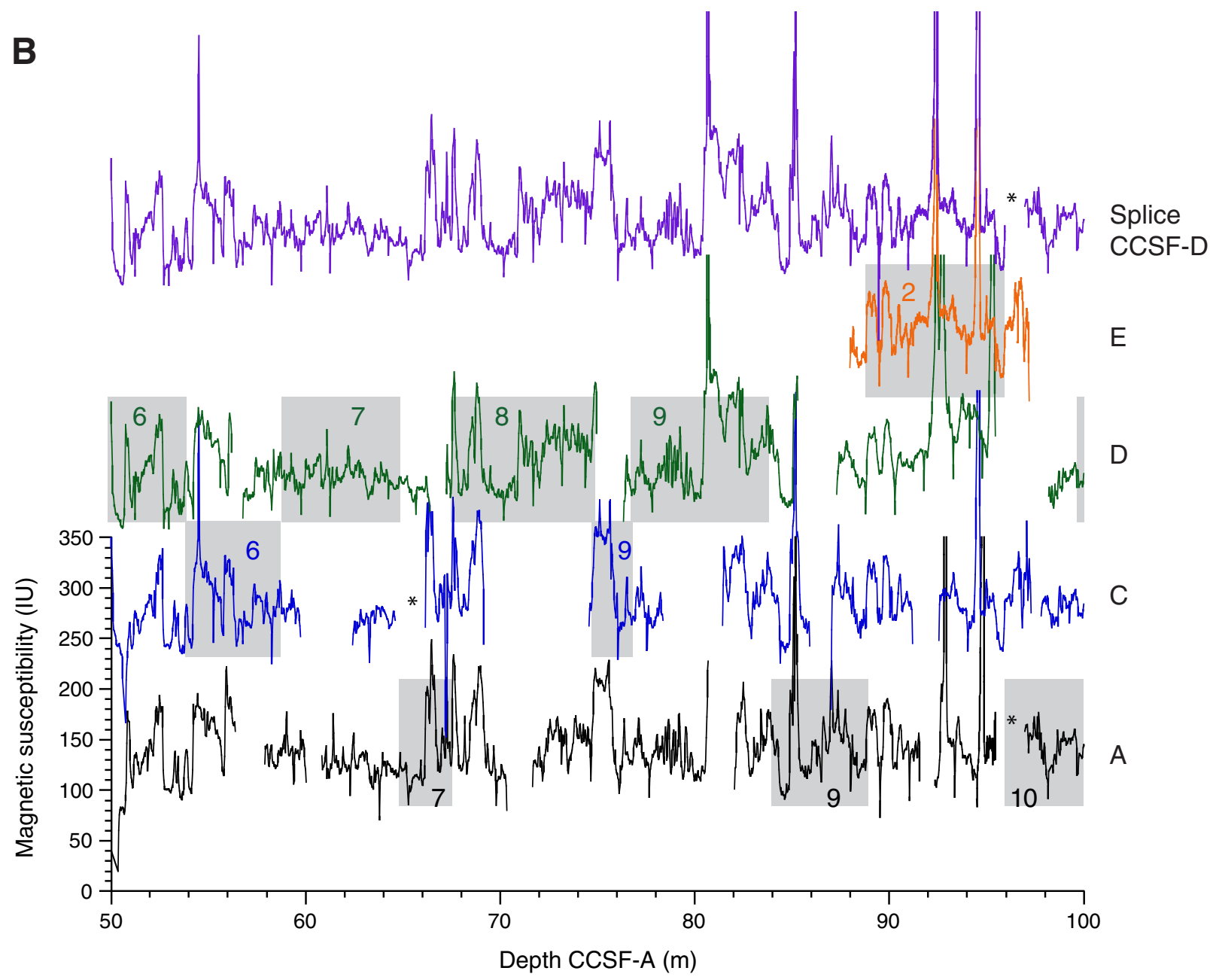


Figure F21 (continued). C. 100-150 m CCSF-A. (Continued on next page.)

C

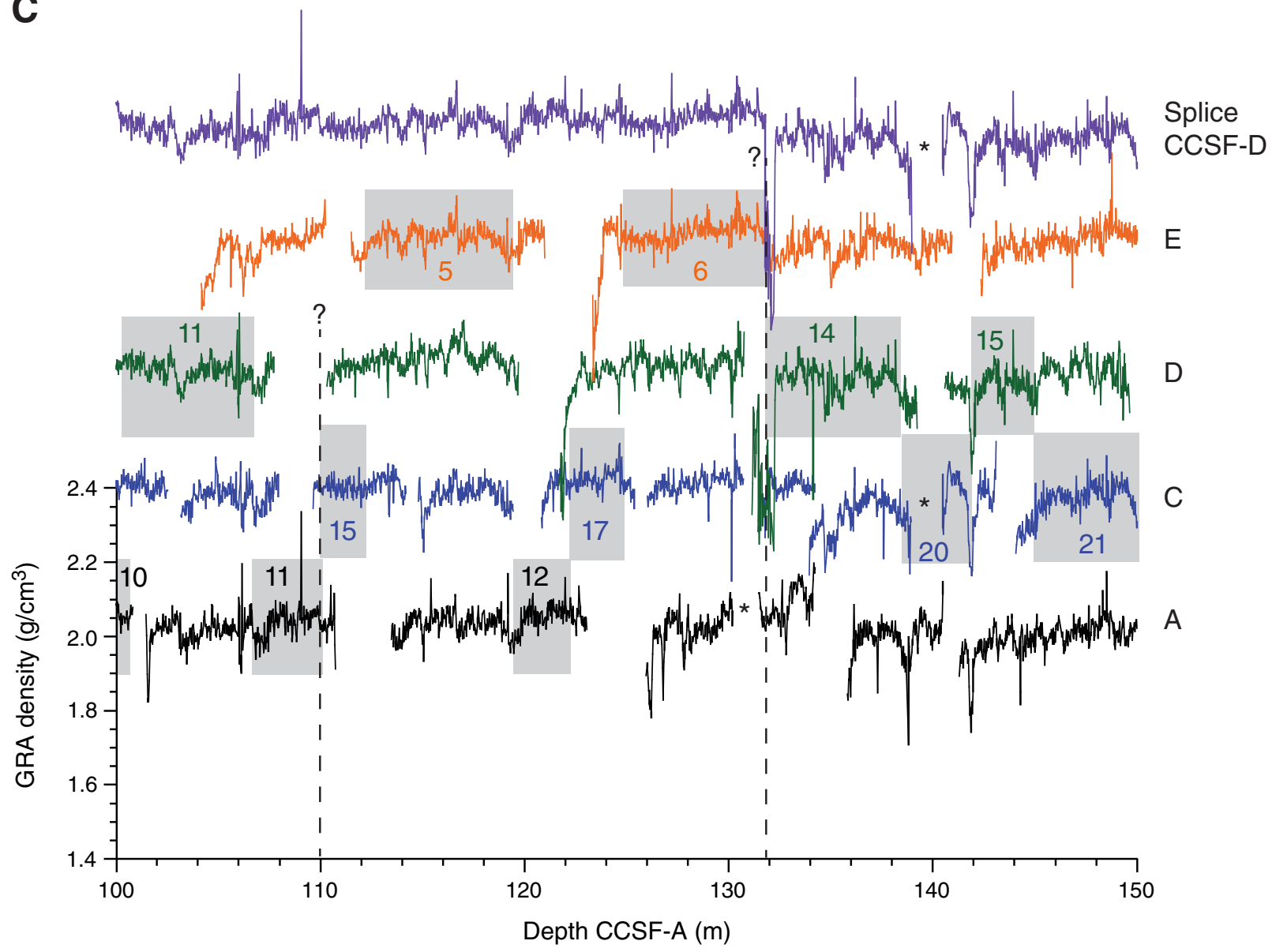


Figure F21 (continued). D. 150-200 m CCSF-A. (Continued on next page.)

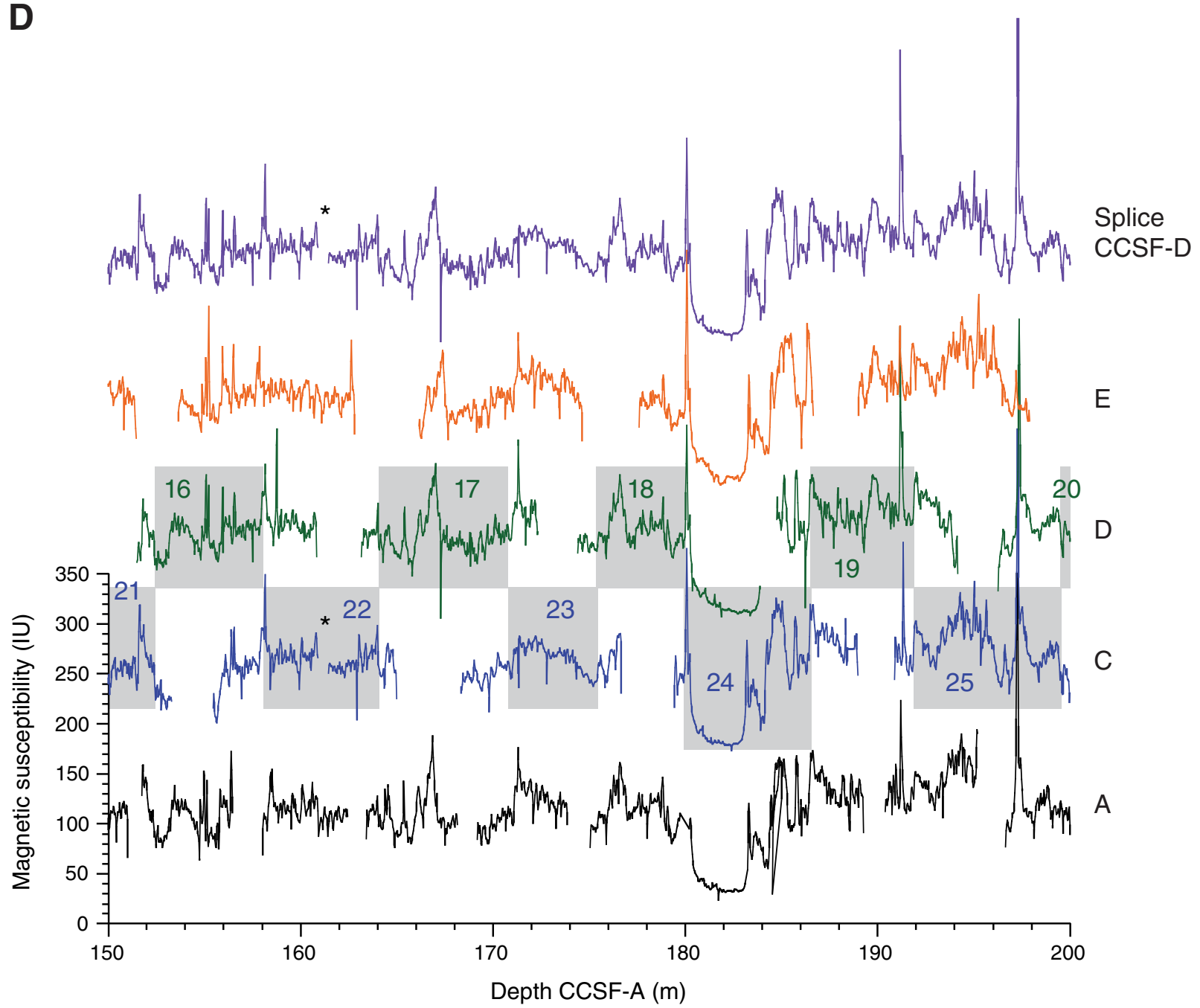


Figure F21 (continued). E. 200-280 m CCSF-A.

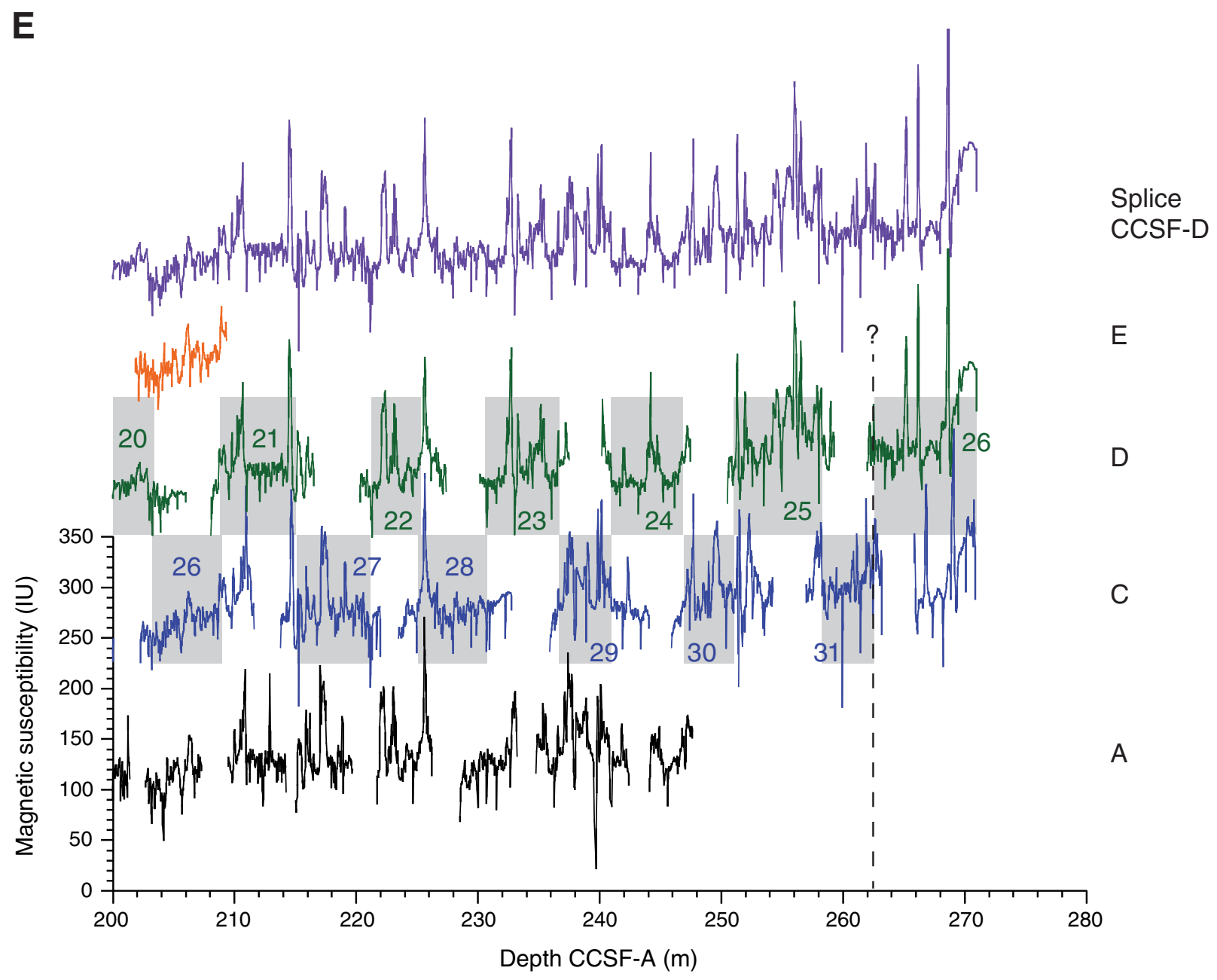


Figure F22. GRA bulk density data for the interval of the continuous splice in Holes U1418A-U1418E and the splice record. Gray boxes = intervals used to construct the splice; numbers indicate core numbers from each hole used in the splice. Dashed vertical lines with question marks indicate intervals where tie points should be treated with caution (see text for details). Asterisks = intervals in which density data could not be run on the WRMSL because of core-liner patches; in these cases density was generally available from STMSL data, except for Core 341-U1418A-13H-5, where a patched liner made the core section too wide for both core loggers. A. 0$50 \mathrm{~m}$ CCSF-A. (Continued on next four pages.)

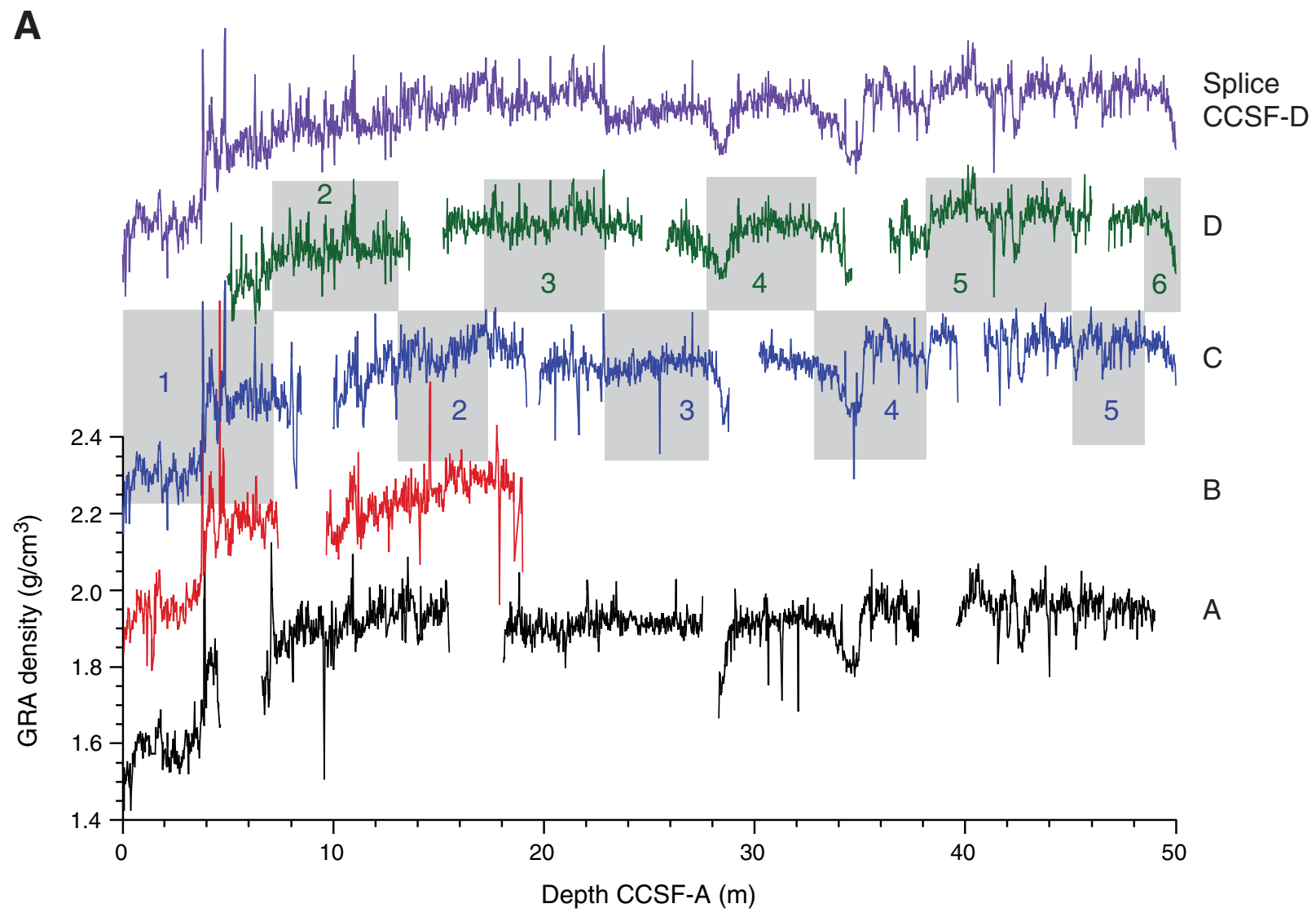


Figure F22 (continued). B. 50-100 m CCSF-A. (Continued on next page.)

B
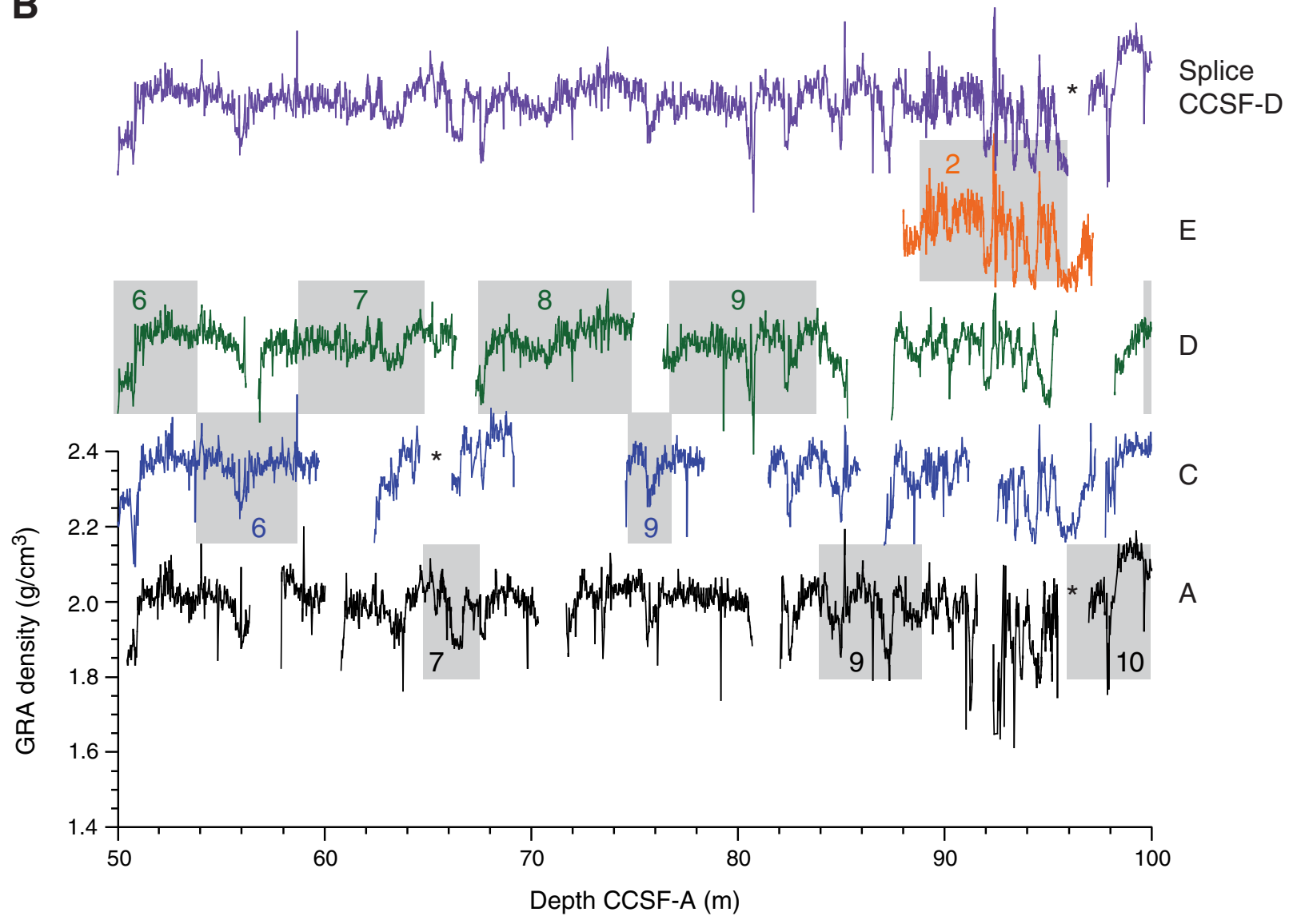
Figure F22 (continued). C. 100-150 m CCSF-A. (Continued on next page.)

C

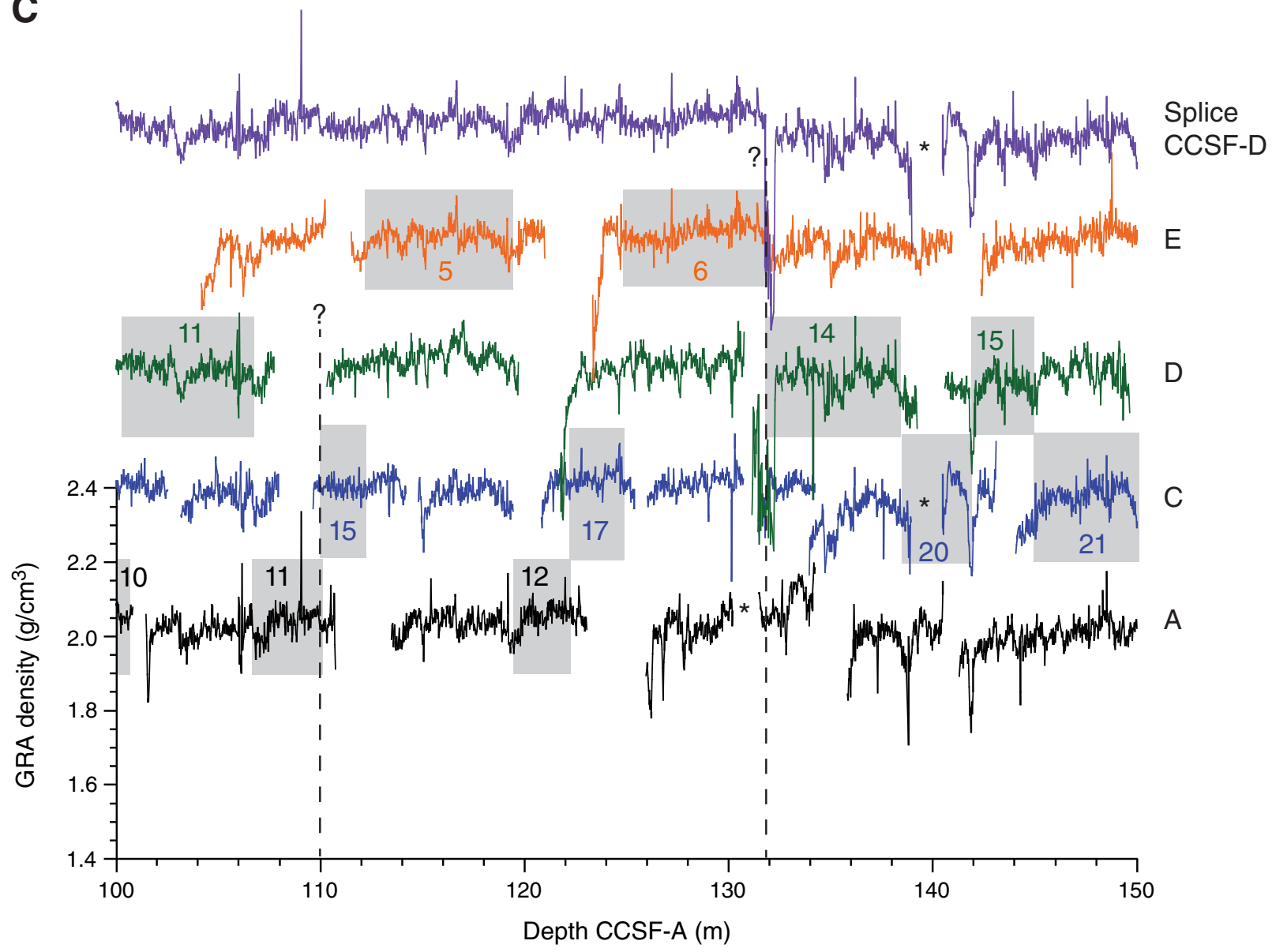


Figure F22 (continued). D. 150-200 m CCSF-A. (Continued on next page.)

D

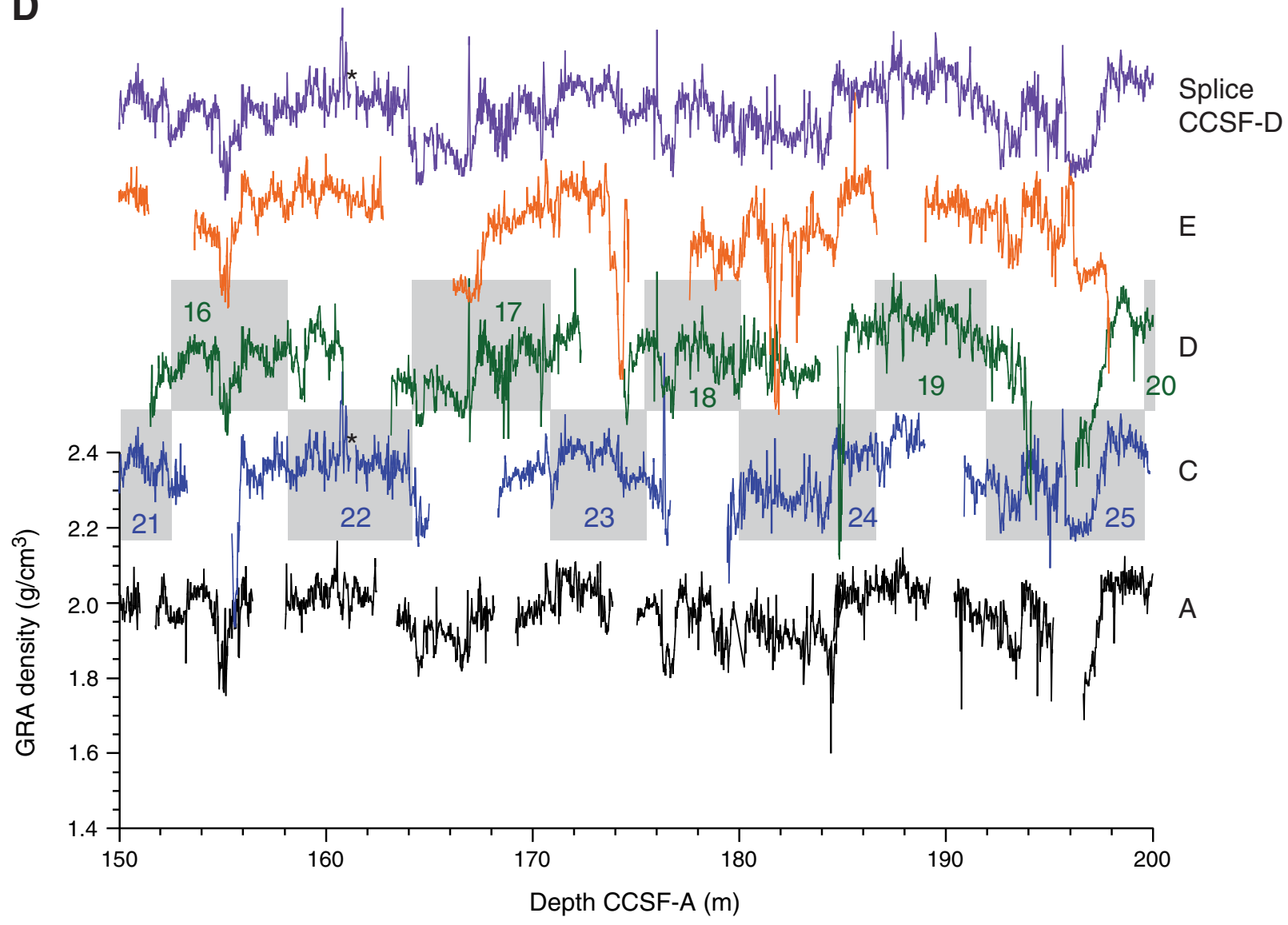


Figure F22 (continued). E. 200-280 m CCSF-A.

E
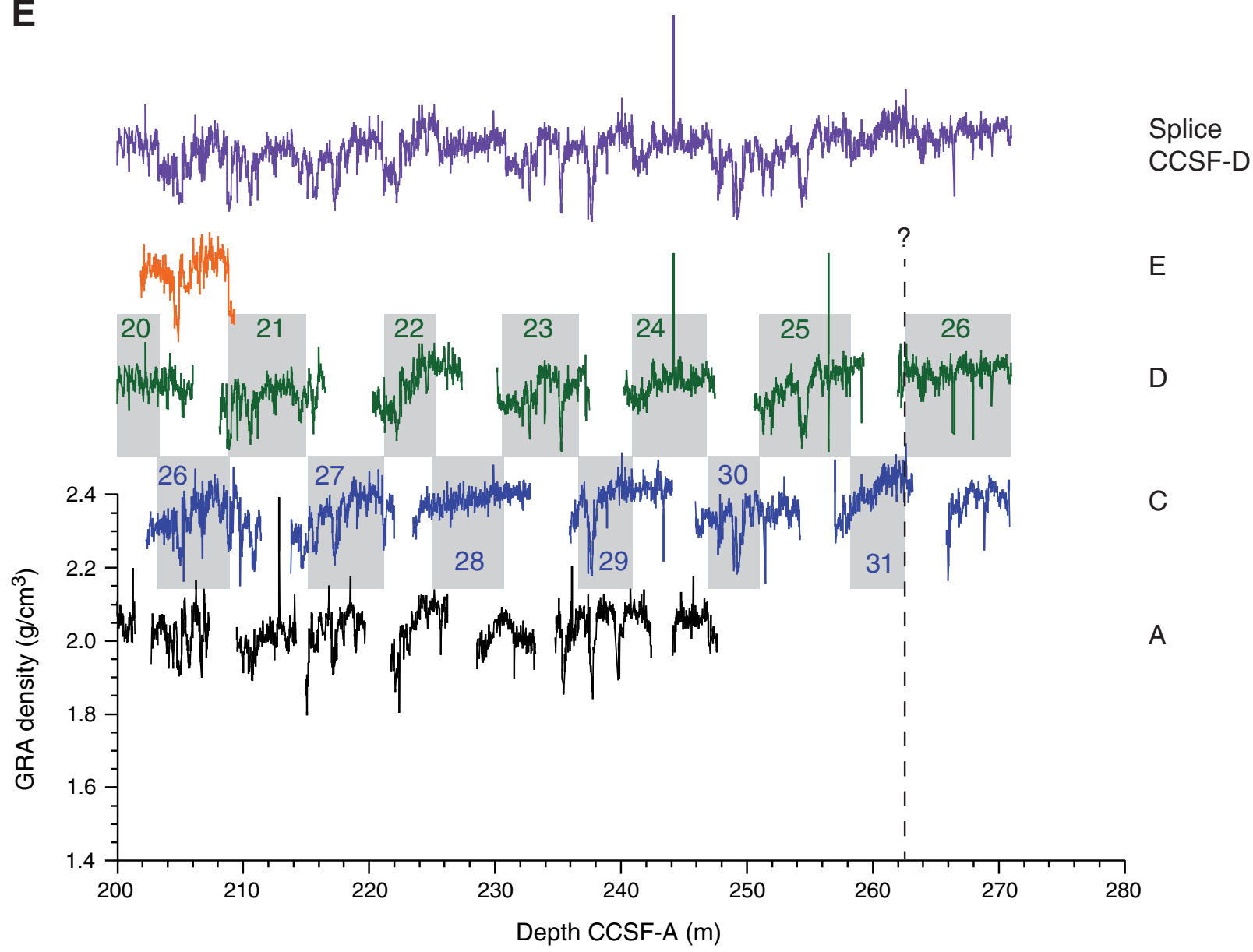
Figure F23. Affine values, Holes U1418A-U1418F. Equations denote the relationship between the affine values and core top depth for each of the three segments of the line of best fit (black line).

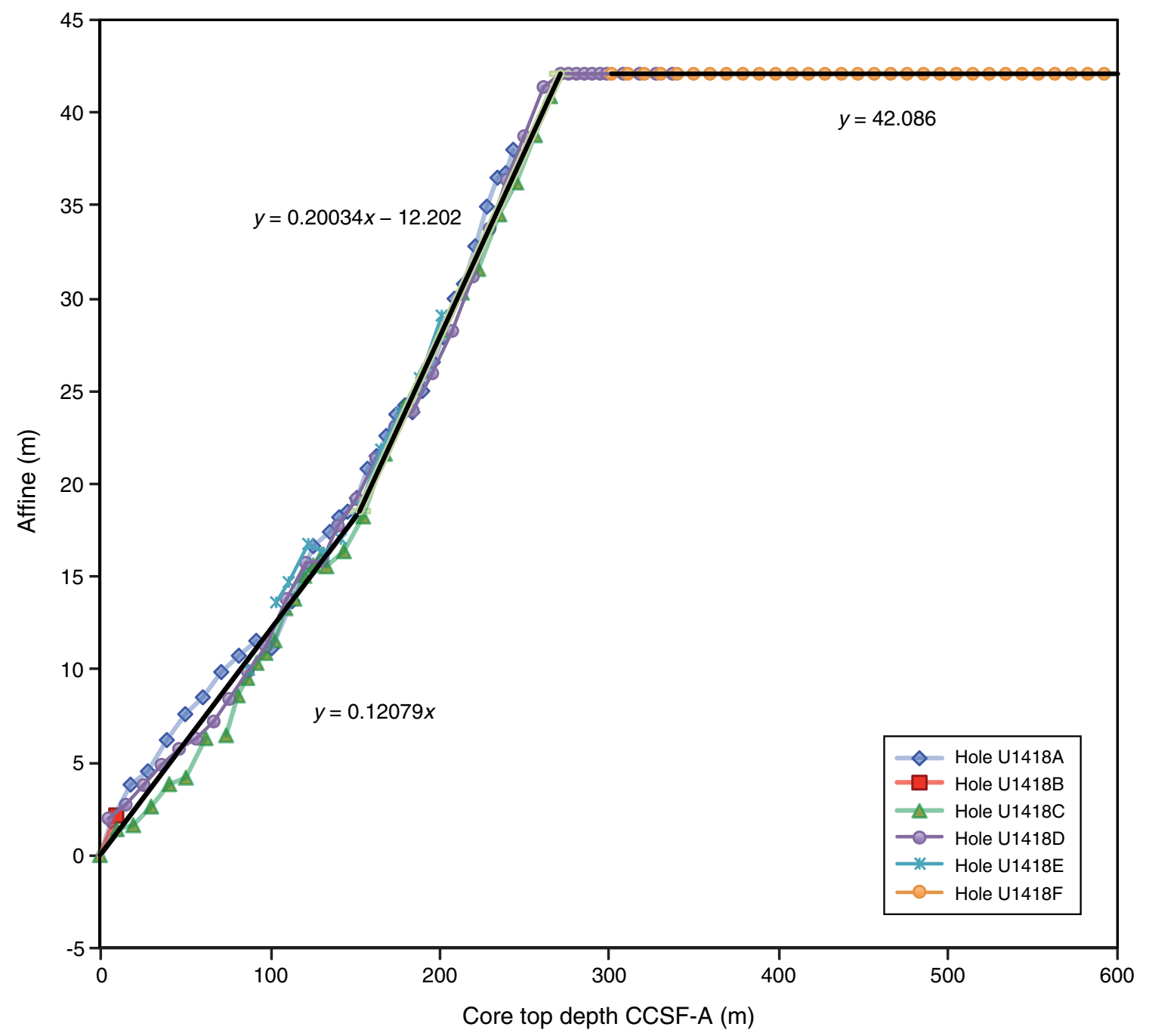


Figure F24. Shipboard age model, Site U1418. Red and blue lines indicate minimum and maximum age models described in text.

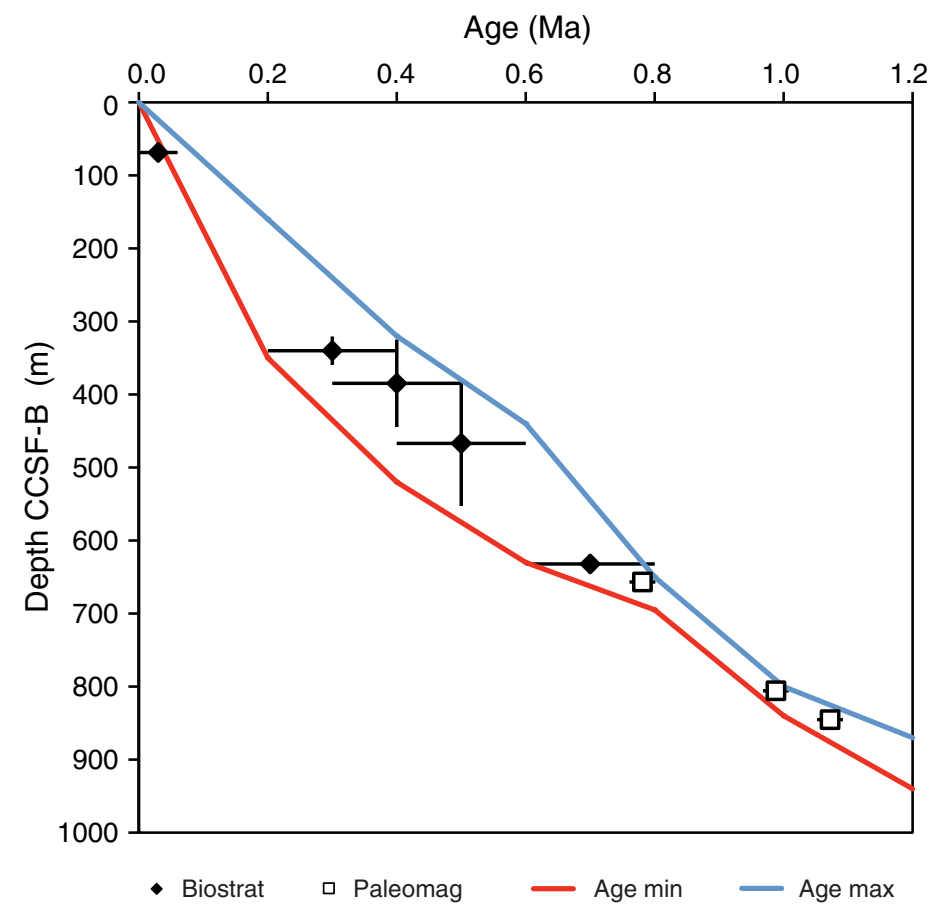


Figure F25. Shipboard sedimentation rates for Site U1418 with $+1 \sigma$ uncertainties (dashed lines) calculated over 0.2 m.y. intervals from 0 to $1.2 \mathrm{Ma}$, as a function of (A) CCSF-B depths and (B) age.
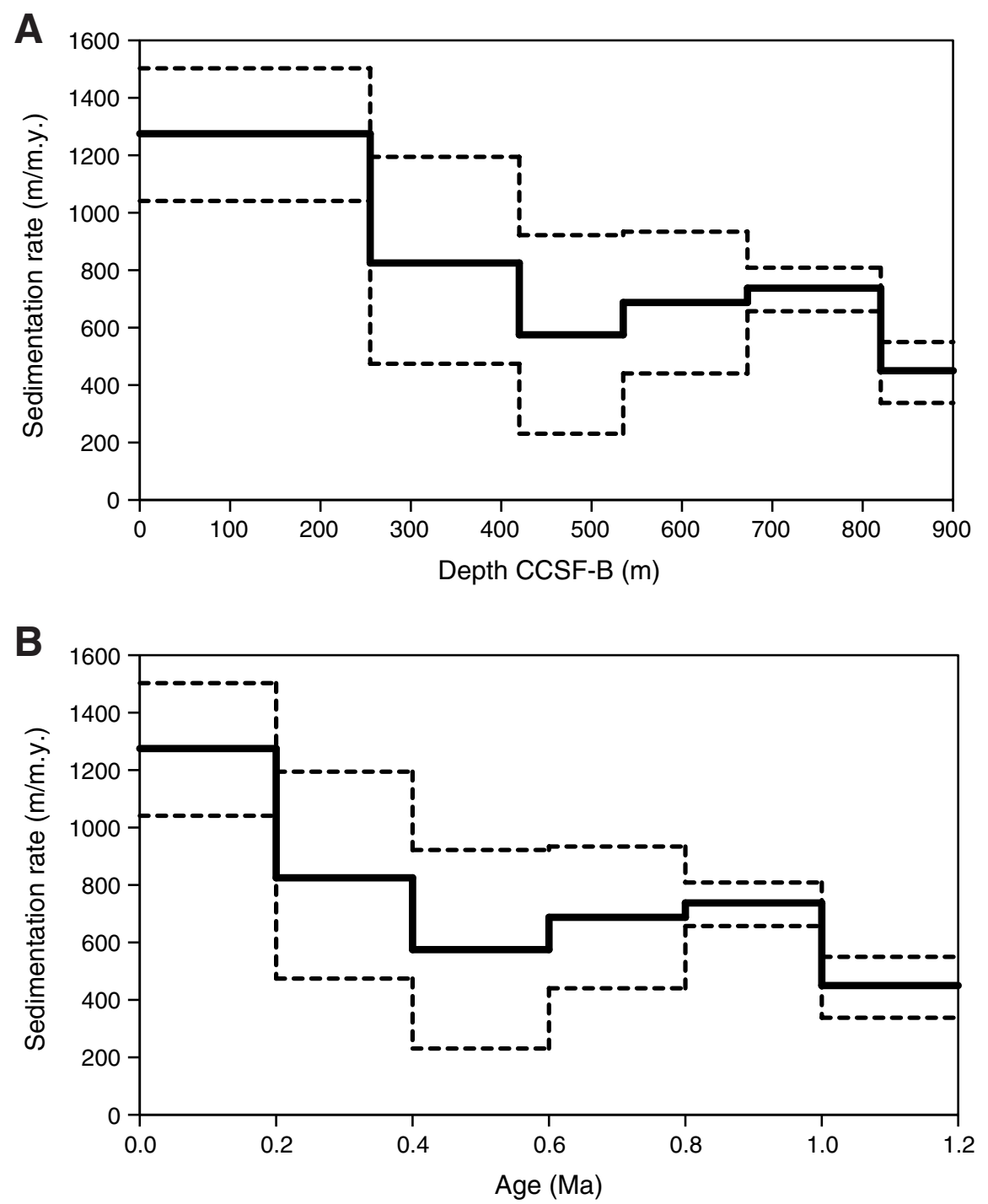
Figure F26. Dissolved chemical concentrations and headspace gas, Site U1418. A. Alkalinity. B. pH. C. Sulfate. D. Ammonium. E. Bromide. F. Methane. G. Ethane. H. Silica. I. Salinity. J. Chloride. K. Sodium. Full details of Lithology column are shown in Figure F12 (see "Lithostratigraphy").
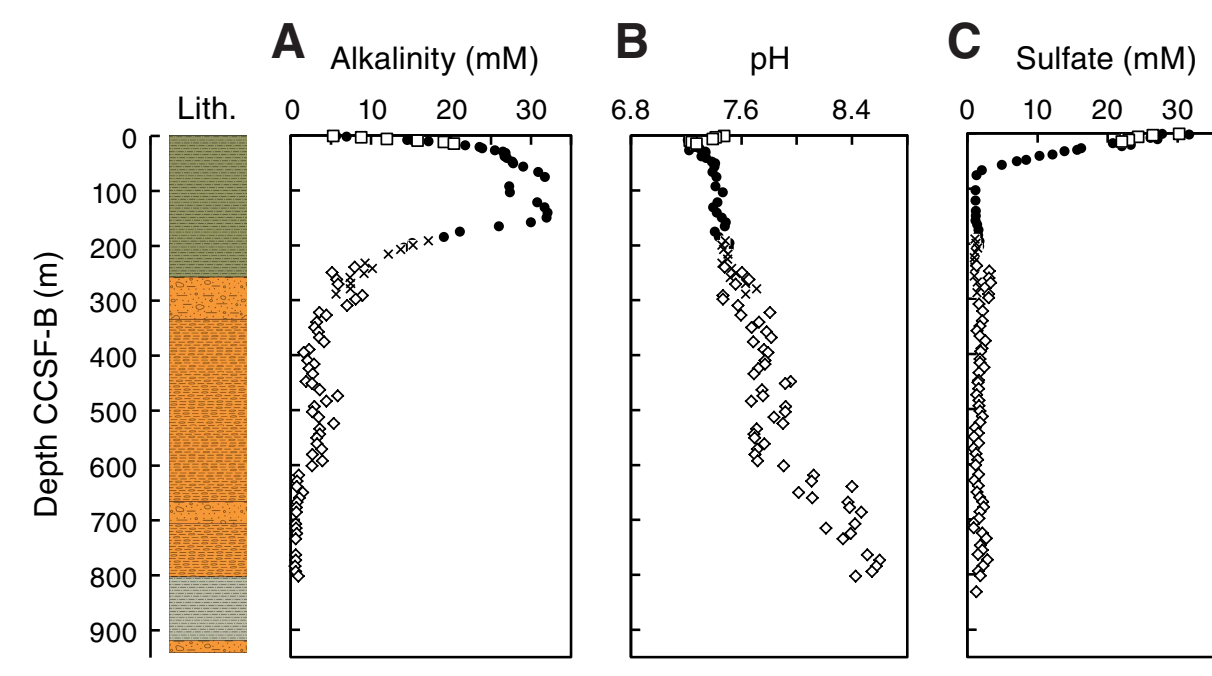

D Ammonium (mM) $_{\text {Am }}$

E Bromide (mM)
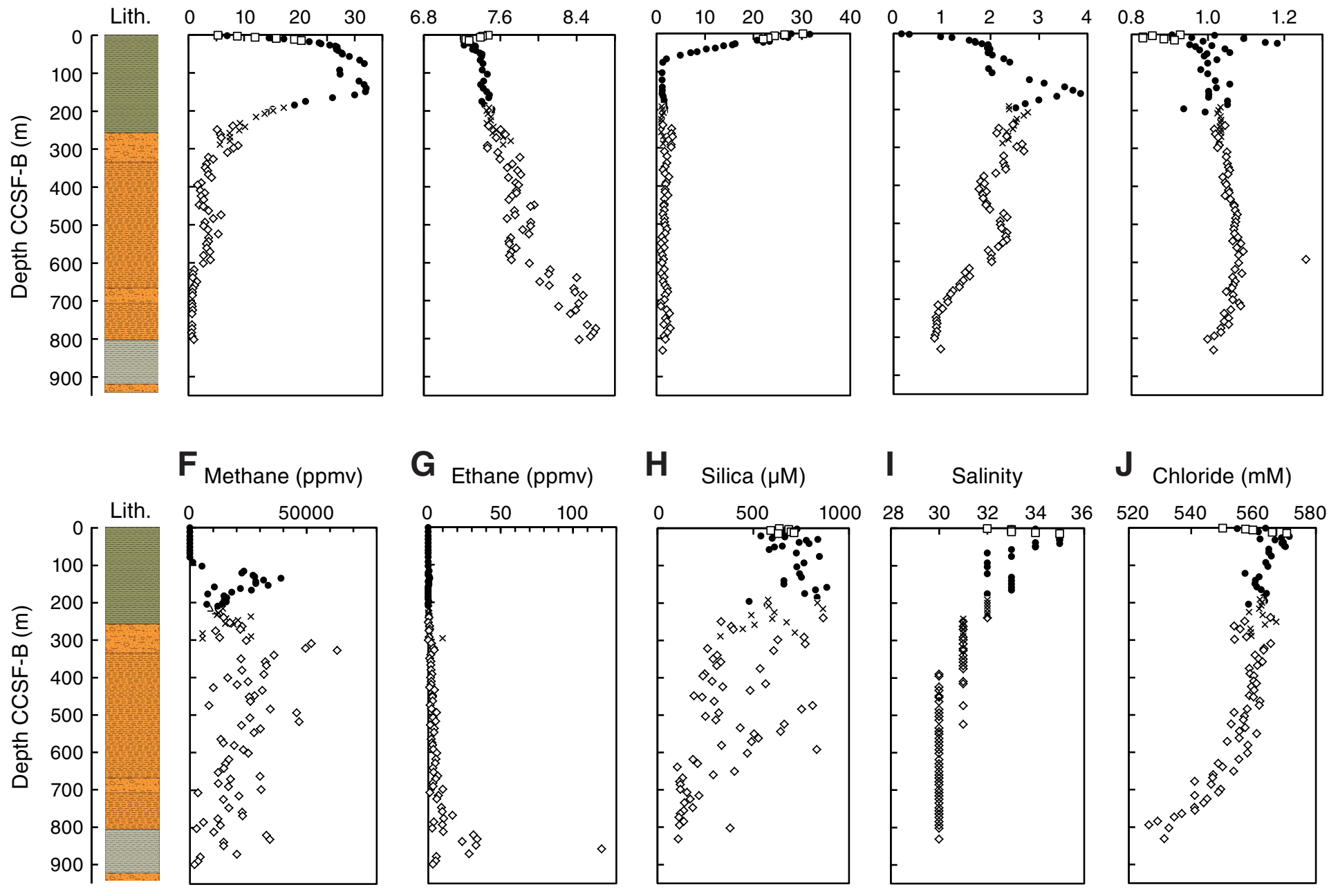

J Chloride (mM)
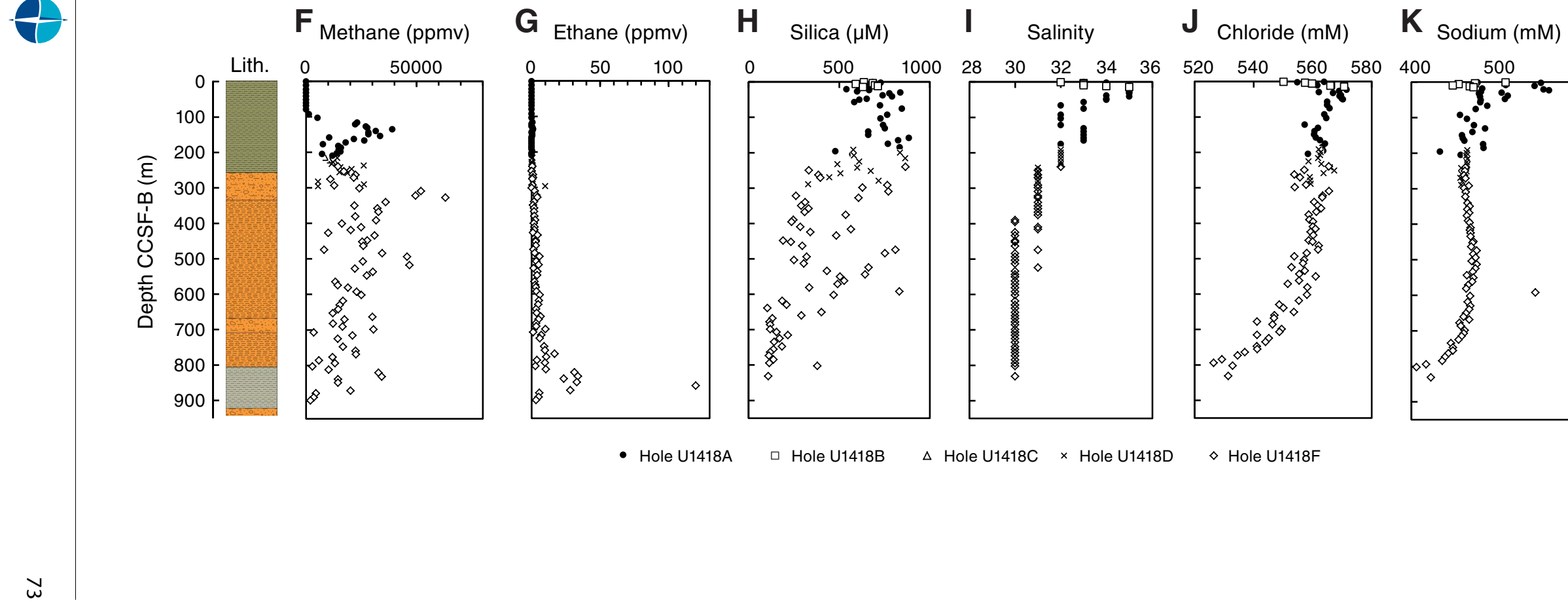

- Hole U1418A

$\square$ Hole U1418B

$\Delta$ Hole U1418C $\times$ Hole U1418D
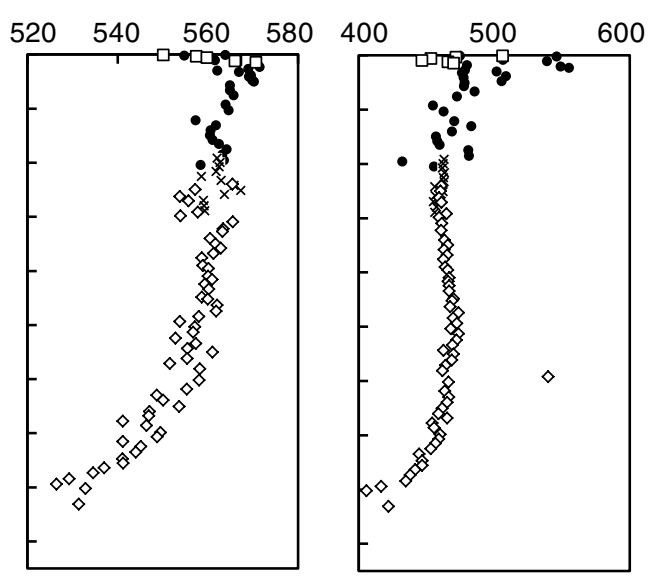
Figure F27. Dissolved chemical concentrations, Site U1418. A. Calcium. B. Potassium. C. Magnesium. D. Lithium. E. Boron. F. Barium. G. Strontium. H. Iron. I. Manganese. J. Phosphate. Full details of Lithology column are shown in Figure F12 (see "Lithostratigraphy").

A Calcium (mM)

B Potassium (mM)
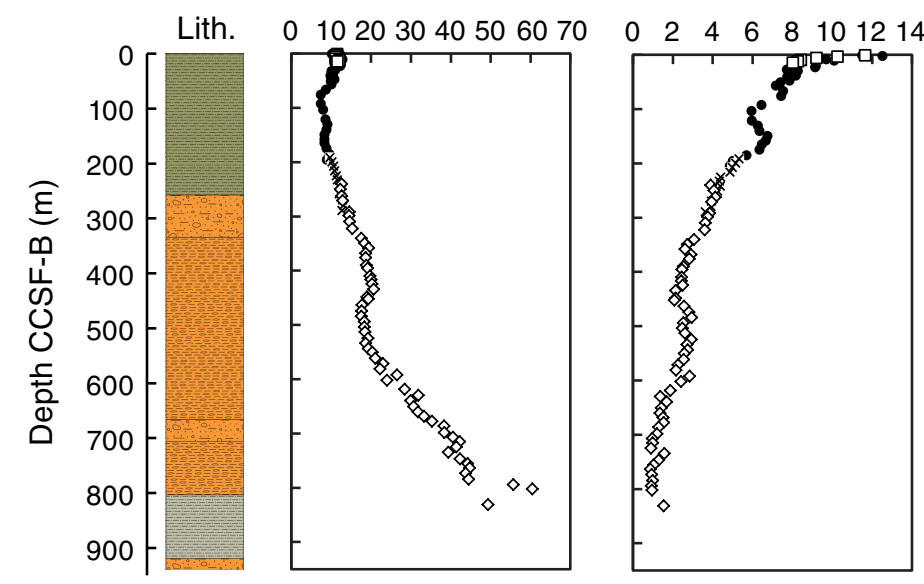

C Magnesium (mM)

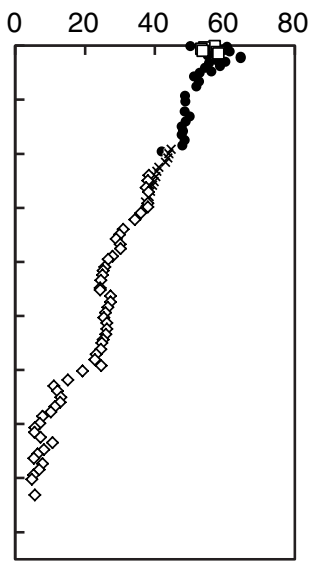

F Barium ( $\mu \mathrm{M})$
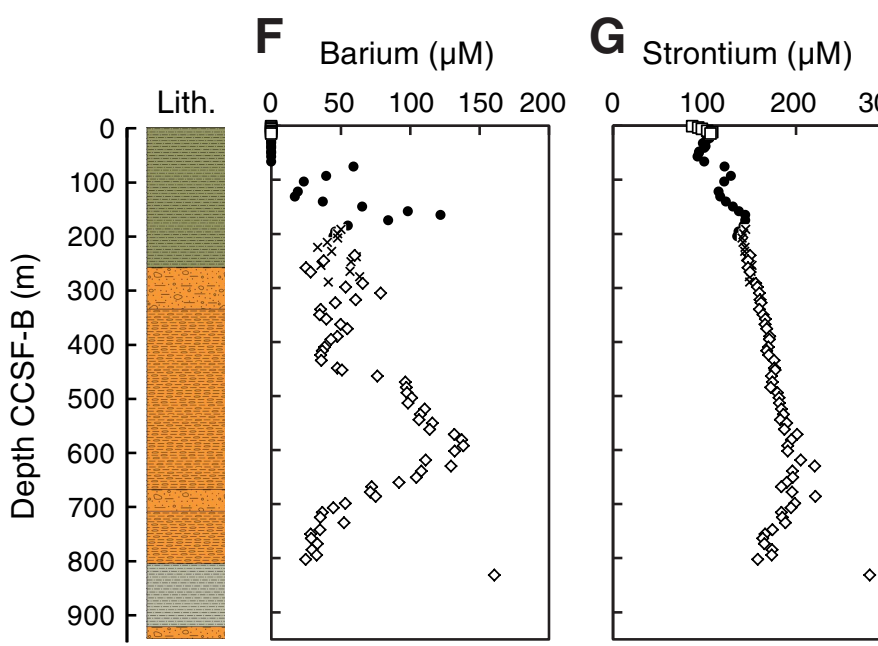

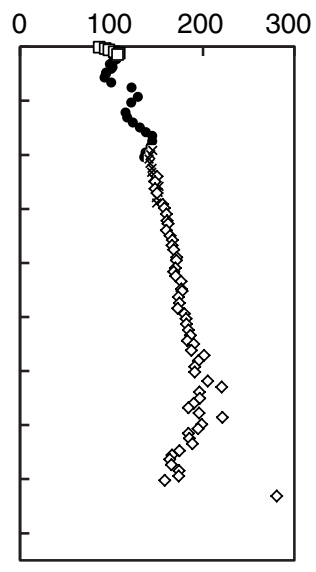

- Hole U1418A
H Iron $(\mu \mathrm{M})$

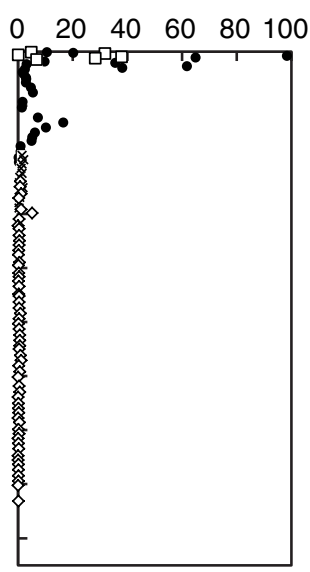

Hole U1418B
D Lithium ( $\mu \mathrm{M})$

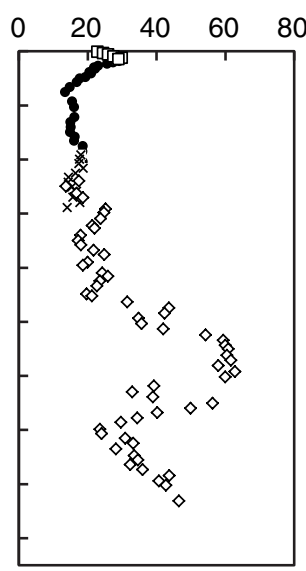

I Manganese $(\mu \mathrm{M})$

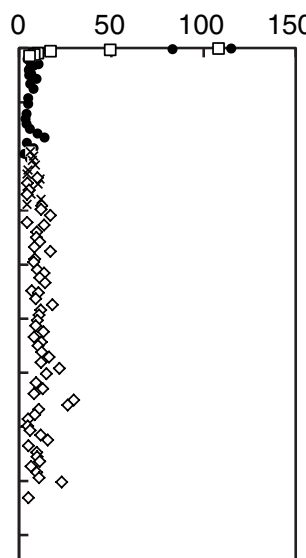

J Phosphate $(\mu \mathrm{M})$

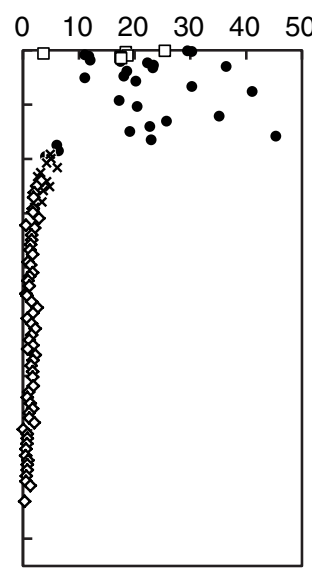


Figure F28. Solid-phase chemical parameters, Site U1418. A. Total organic carbon (TOC). B. Total nitrogen (TN). C. TOC/TN ratio (C/N). D. $\mathrm{CaCO}_{3}$. E. Scatter plot of TOC vs. TN. The potential contribution of inorganic $\mathrm{N}$ to the TN signal is estimated where the linear regression line intercepts the $y$-axis (e.g., Schubert and Calvert, 2001). Full details of Lithology column are shown in Figure F12 (see "Lithostratigraphy").

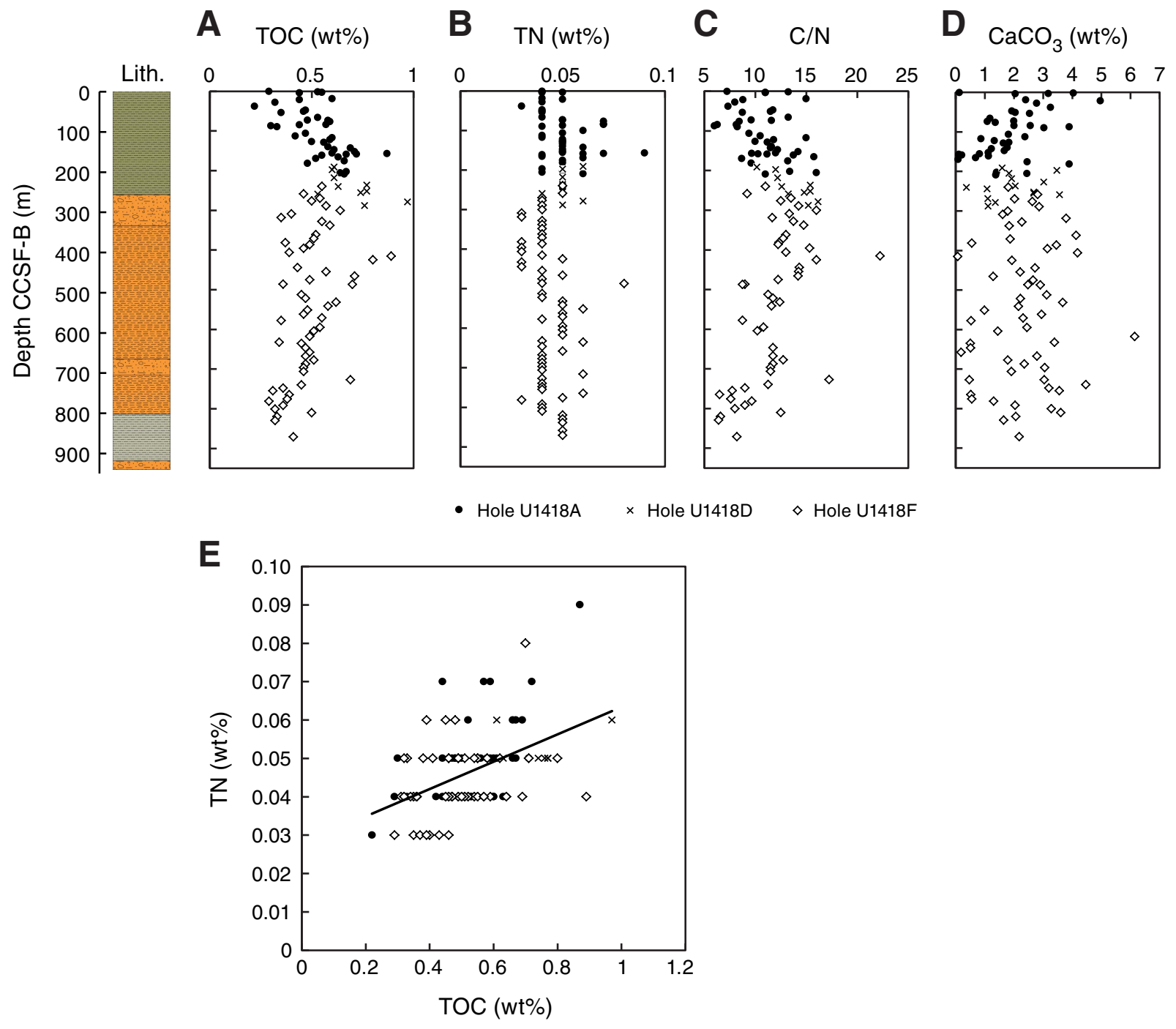


Figure F29. Dissolved chemical concentrations, solid-phase chemical parameters, and headspace gas plotted only for the upper $300 \mathrm{~m}$ CCSF-B at Site U1418. A. Alkalinity. B. Sulfate. C. Ammonium. D. Chloride. E. Sodium. F. Phosphate. G. Calcium. H. Total organic carbon (TOC). I. CaCO ${ }_{3}$ J. Methane.
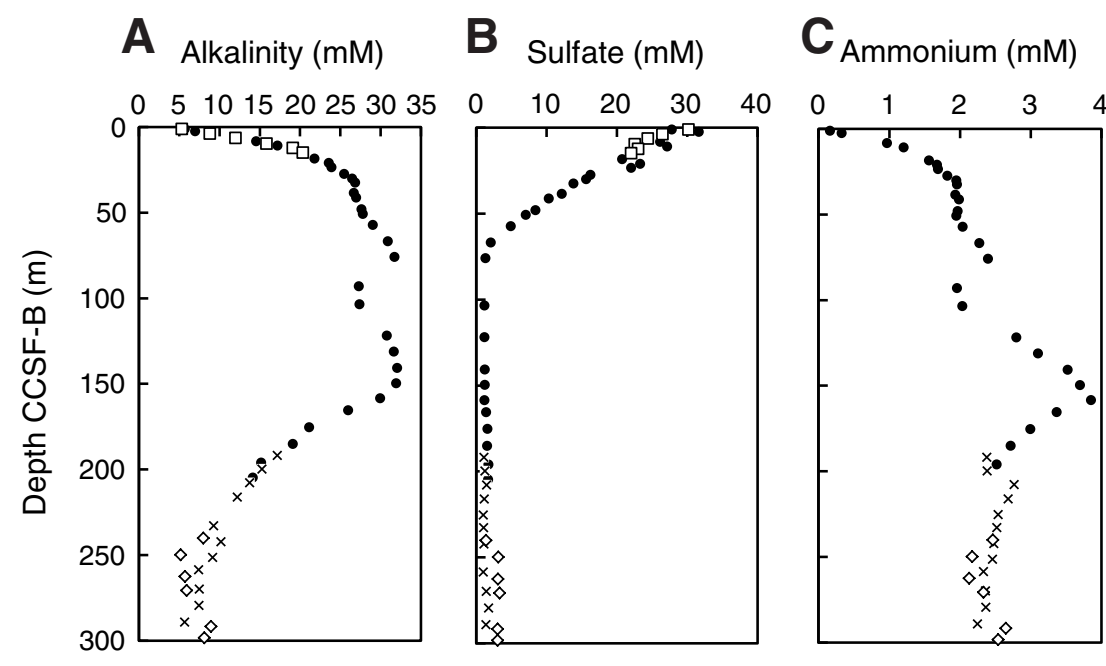

D Chloride (mM)

E Sodium (mM)
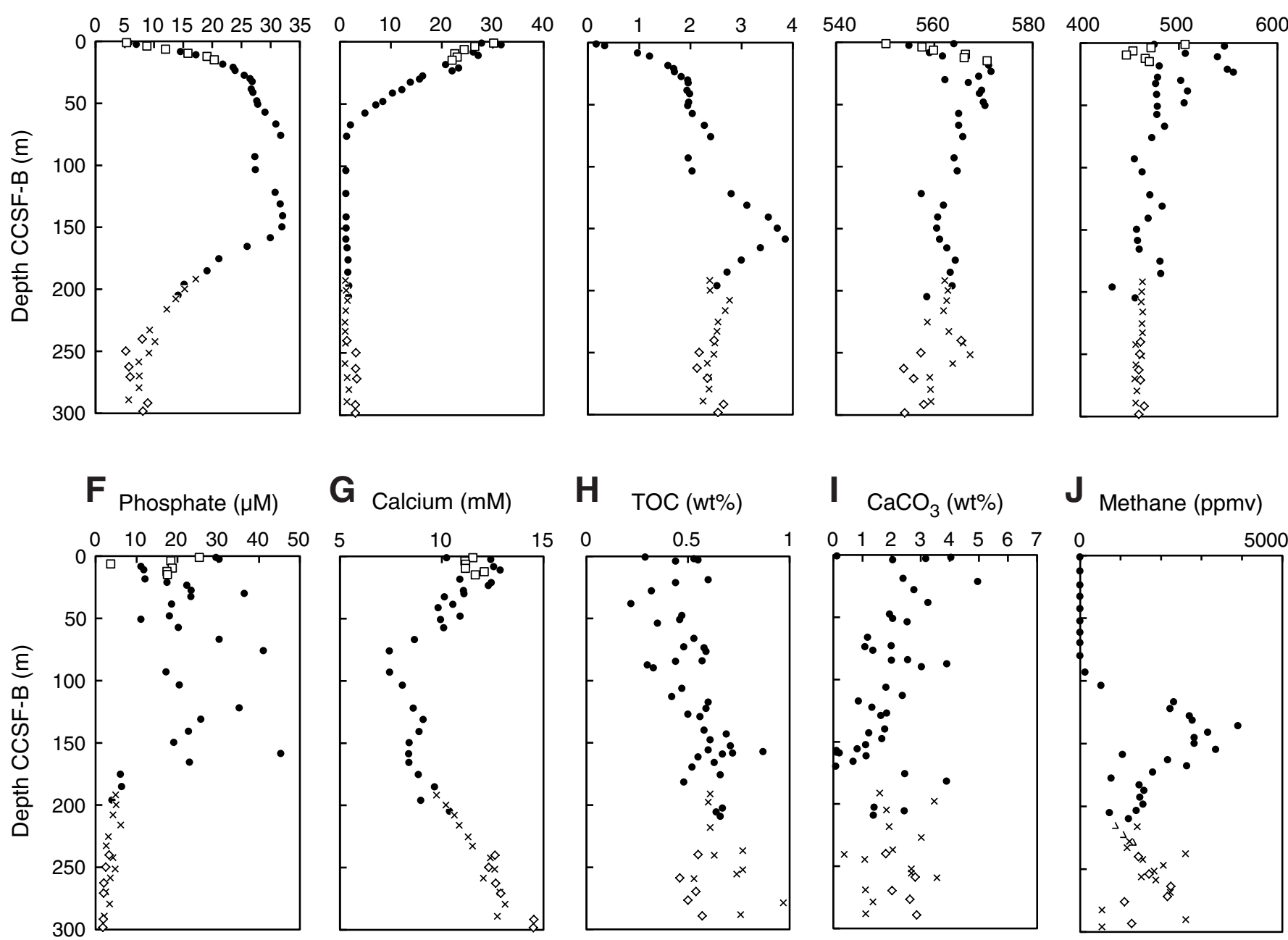

G Calcium (mM)

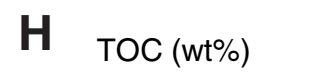

I $\mathrm{CaCO}_{3}(\mathrm{wt} \%)$
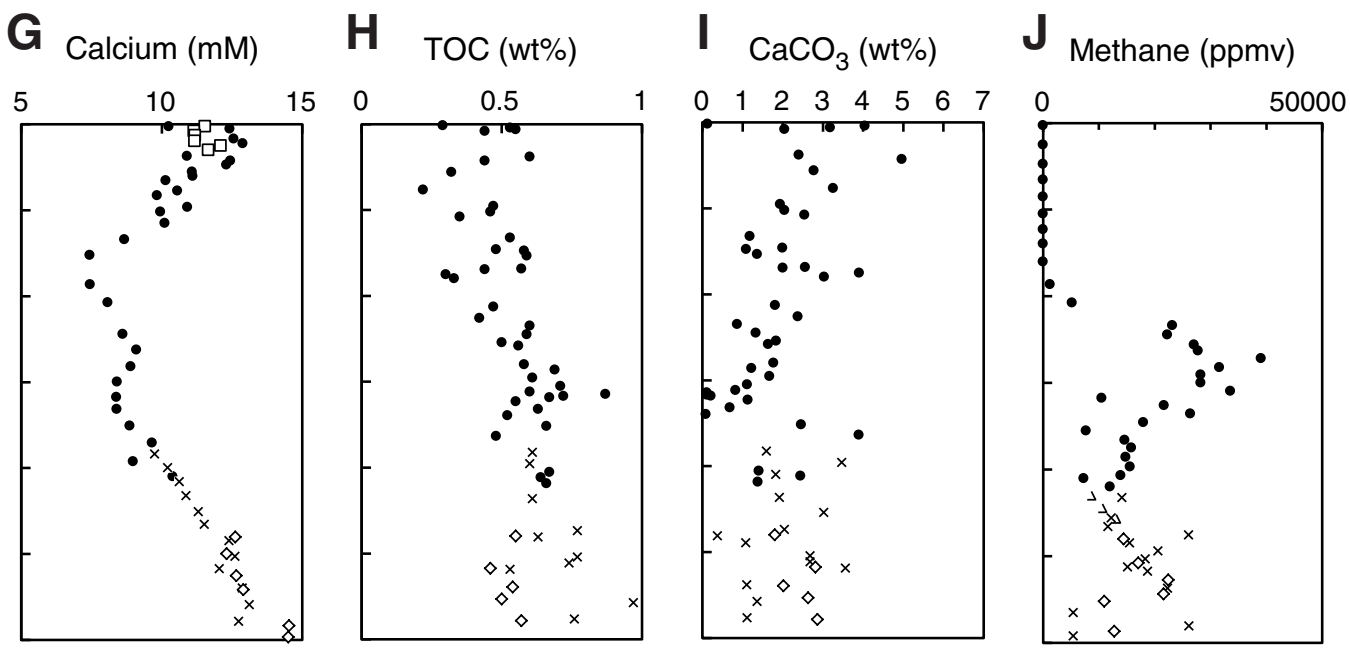

- Hole U1418A

口 Hole U1418B

$\times$ Hole U1418D

$\diamond$ Hole U1418F 
Figure F30. Physical properties measurements, Hole U1418A. WRMSL $=$ Whole-Round Multisensor Logger, MS $=$ magnetic susceptibility. MAD = moisture and density, GRA = gamma ray attenuation. NGR = natural gamma radiation.
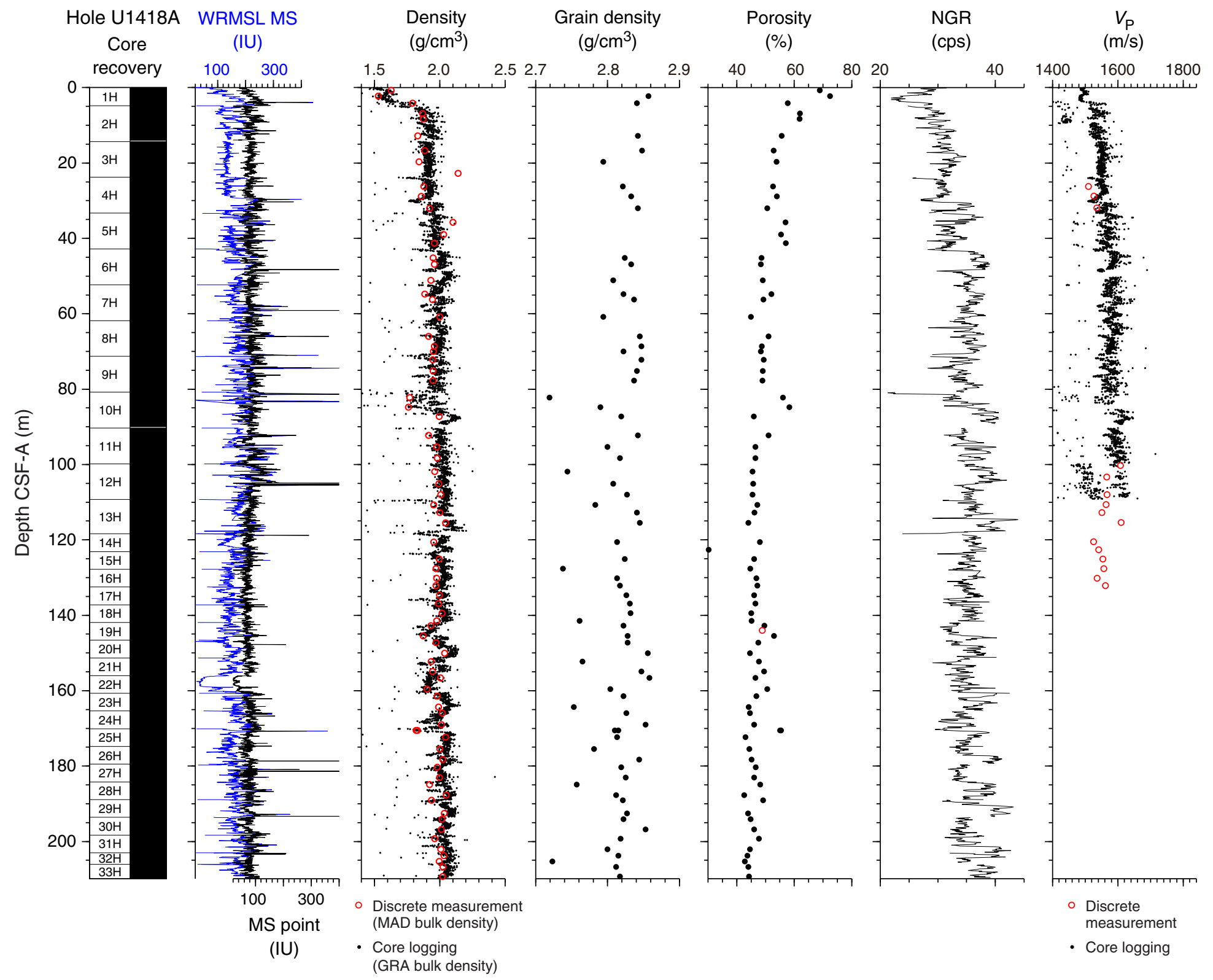

Shear strength
$(\mathrm{kPa})$

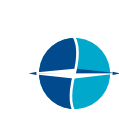


Figure F31. Physical properties measurements, Hole U1418C. WRMSL = Whole-Round Multisensor Logger, MS $=$ magnetic susceptibility $. \mathrm{MAD}=$ moisture and density, GRA = gamma ray attenuation $. \mathrm{NGR}=$ natural gamma radiation.

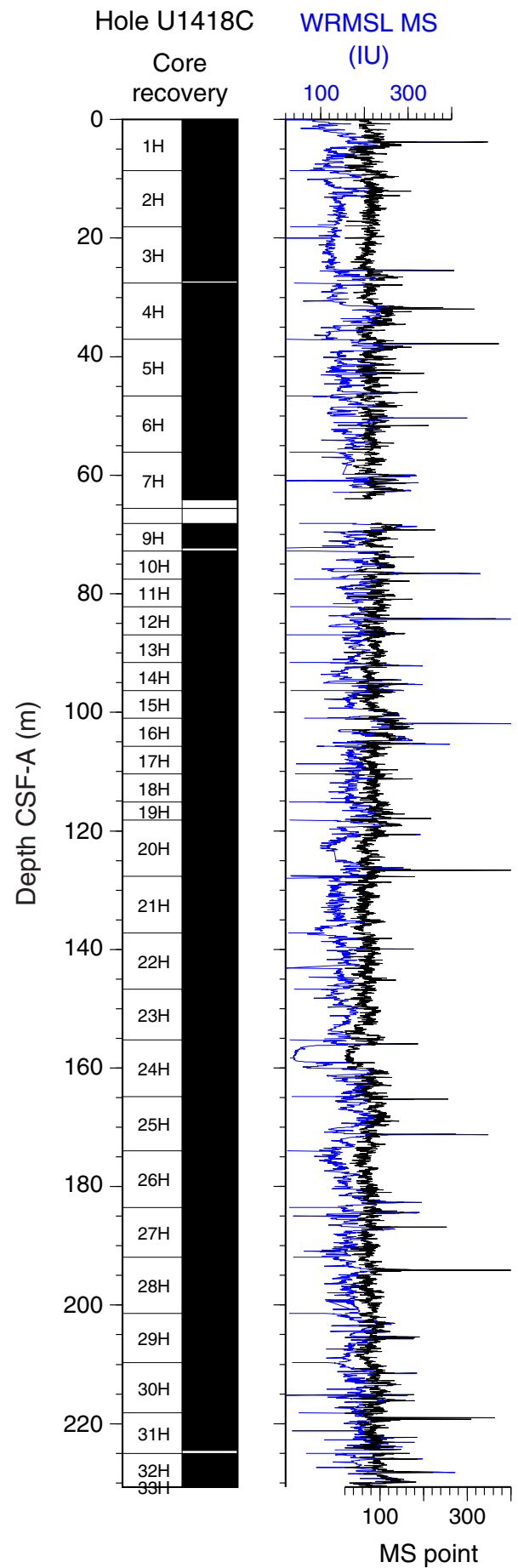

(IU)
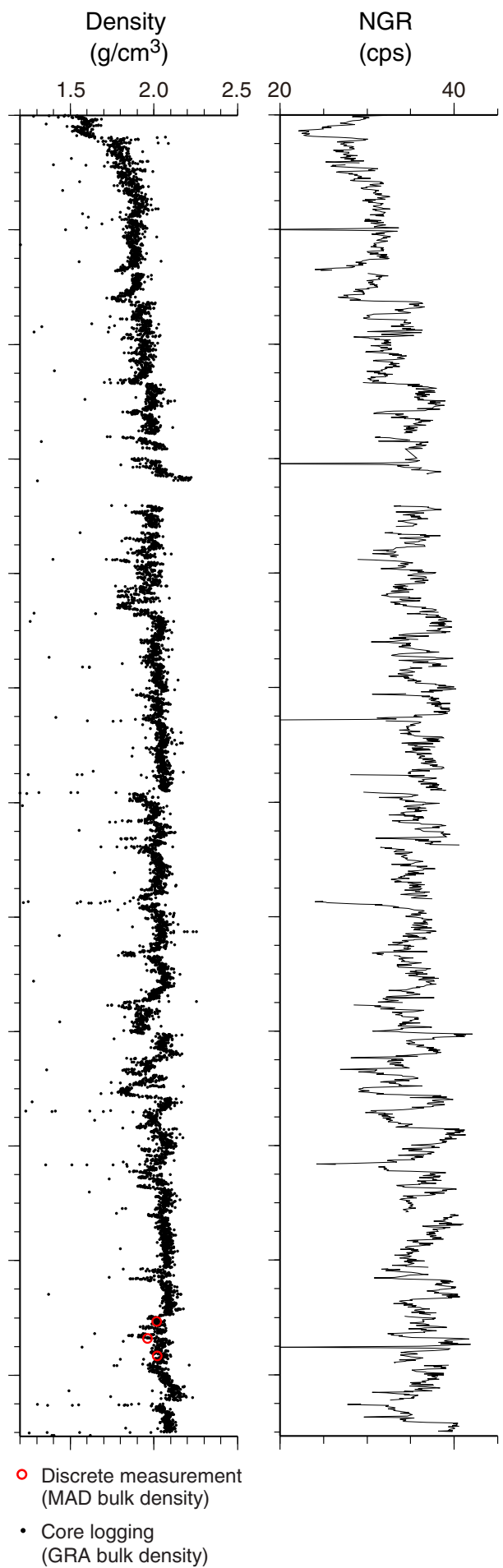

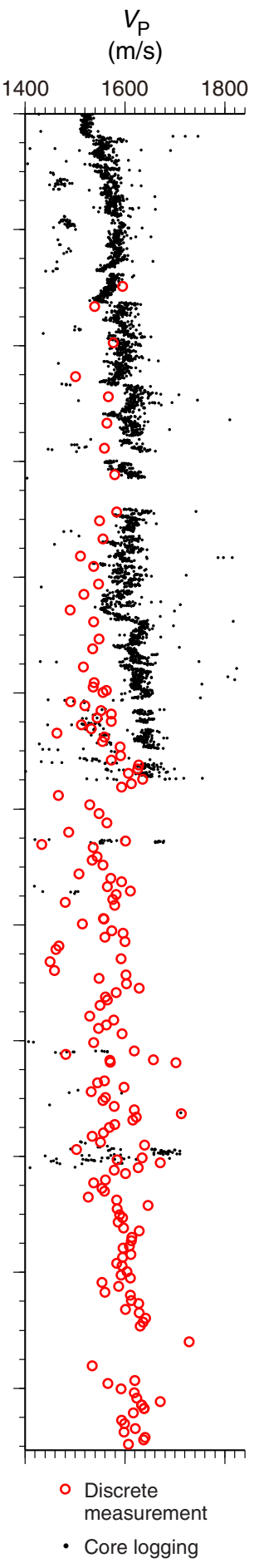


Figure F32. Physical properties measurements, Hole U1418D. WRMSL = Whole-Round Multisensor Logger, MS $=$ magnetic susceptibility $. \mathrm{MAD}=$ moisture and density, GRA = gamma ray attenuation $. \mathrm{NGR}=$ natural gamma radiation.

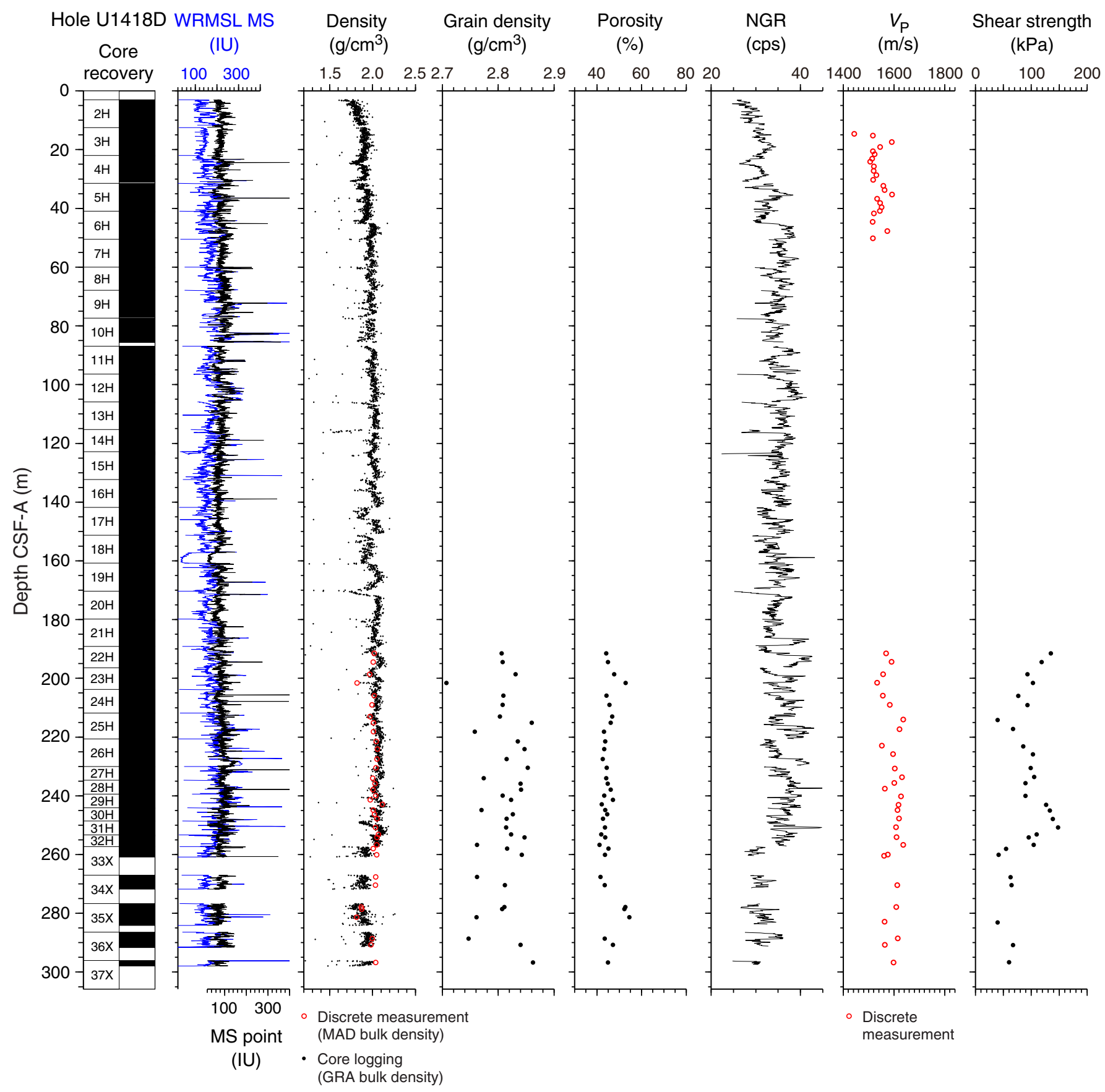


Figure F33. Physical properties measurements, Hole U1418E. WRMSL = Whole-Round Multisensor Logger, MS $=$ magnetic susceptibility. GRA = gamma ray attenuation. NGR = natural gamma radiation .
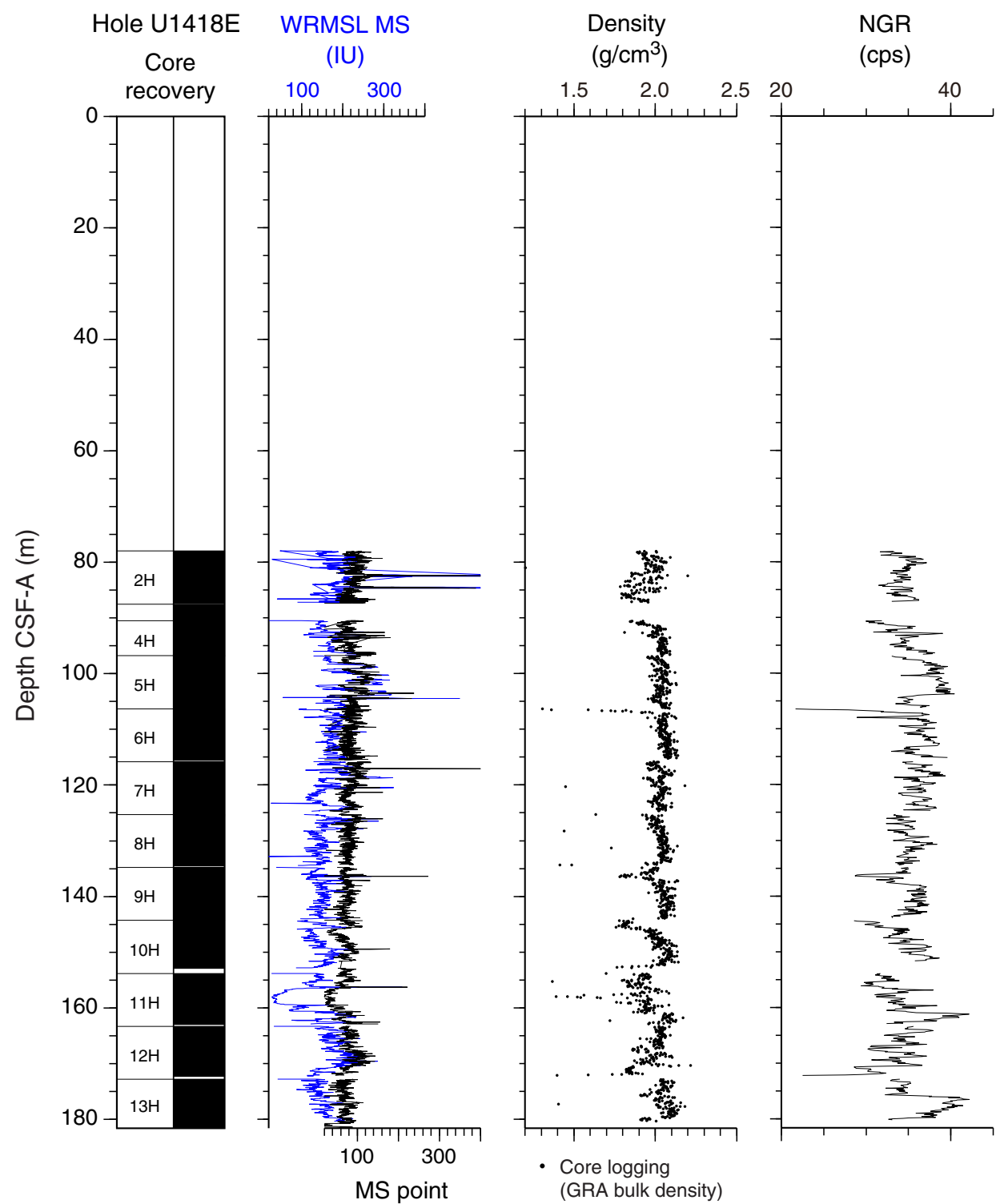

(IU) 
Figure F34. Physical properties measurements, Hole U1418F. WRMSL $=$ Whole-Round Multisensor Logger, MS $=$ magnetic susceptibility. $\mathrm{MAD}=$ moisture and density, GRA = gamma ray attenuation. $\mathrm{NGR}=$ natural gamma radiation. A. 280-640 m CSF-A. (Continued on next page.)

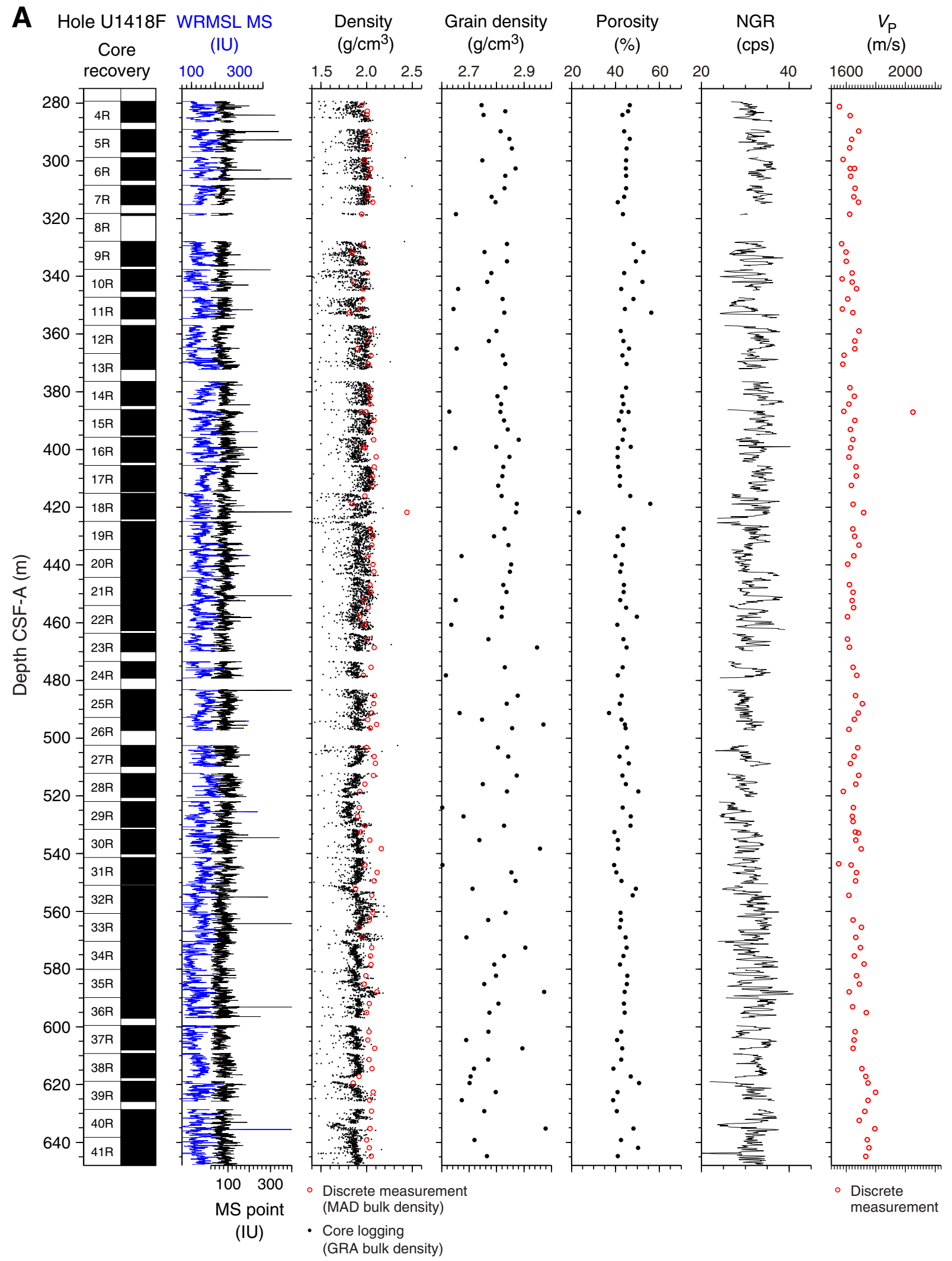


Figure F34 (continued). B. 660-940 m CSF-A.

B Hole U1418F WRMSL MS

Core

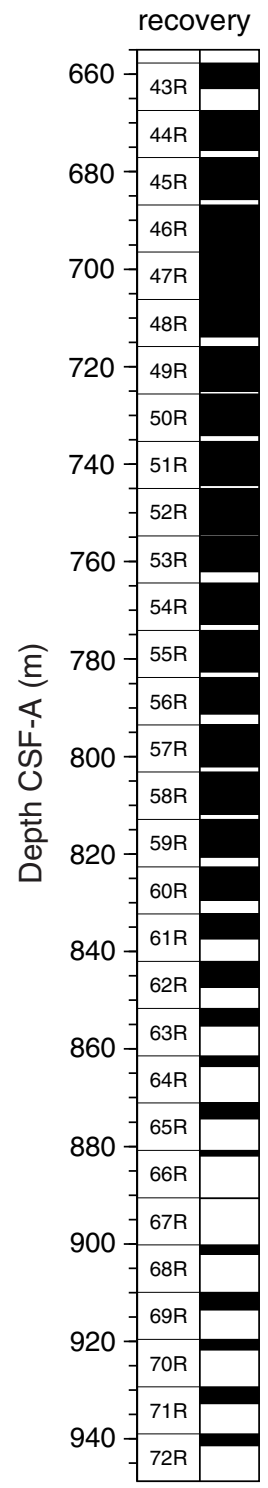

-

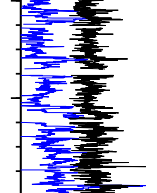

Density

$\left(\mathrm{g} / \mathrm{cm}^{3}\right)$

\begin{tabular}{llll}
1.5 & 2.0 & 2.5 & 2.7 \\
\hline
\end{tabular}
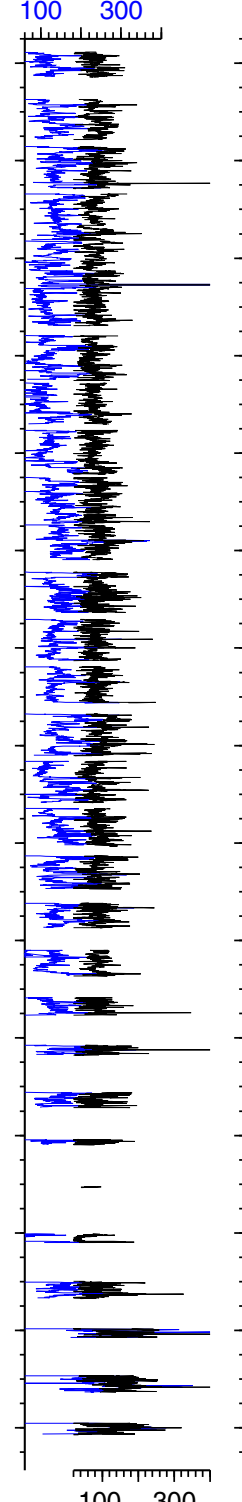

$100 \quad 300$

MS point

(IU)

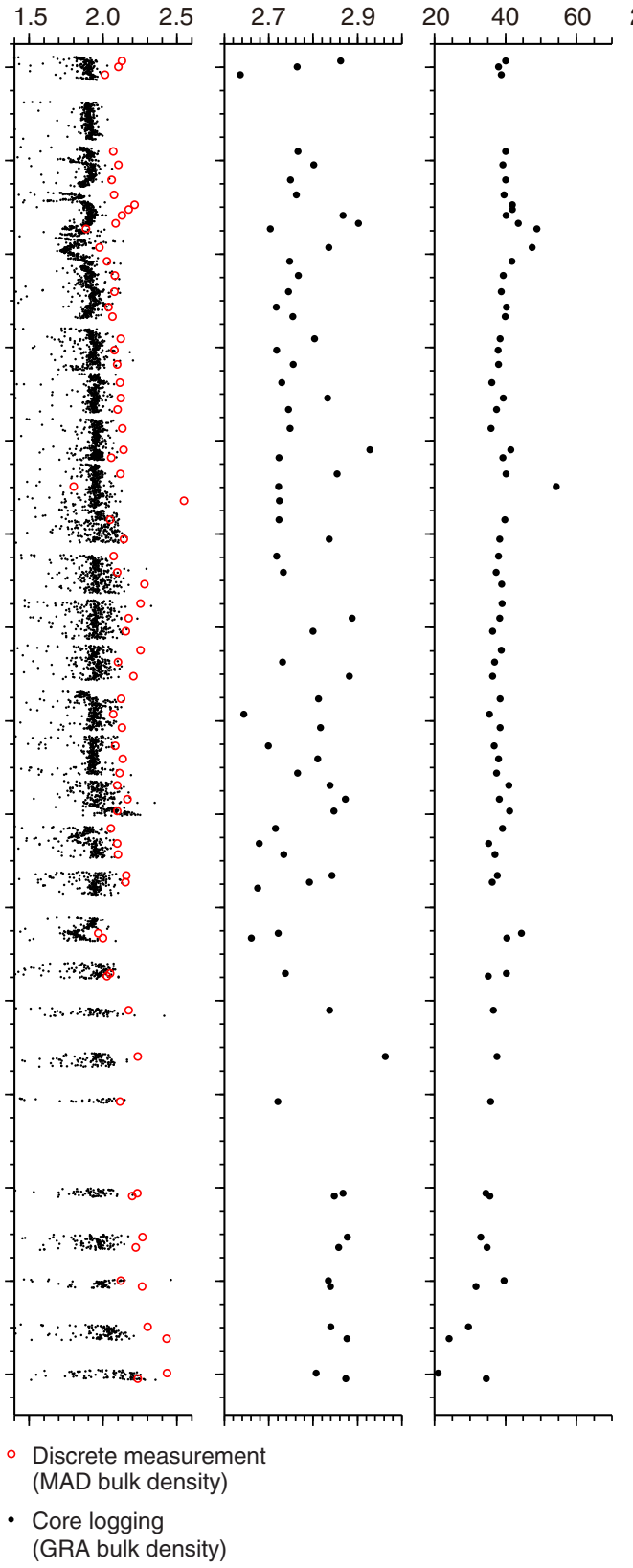

NGR

(cps) $V_{P}$

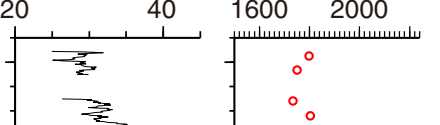

$\frac{z^{2}}{\underline{z^{2}}}$

$\therefore$

$\therefore$

$\therefore$

$\because 0$

$\therefore$

$\therefore$

:

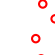

$\therefore$

$\pm$

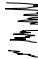

度

$=$

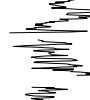

$=$

$=$

$x$

$=$

$-$

$\ldots$

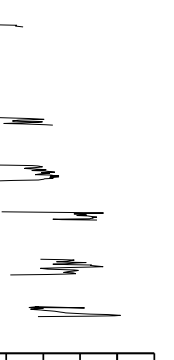

- Discrete

measurement

$\infty$

$\circ$

。

$\infty$

- $\circ$

$\circ \circ$ 
Figure F35. Whole-Round Multisensor Logger (WRMSL) gamma ray attenuation (GRA) bulk density compared to WRMSL magnetic susceptibility (MS) data, Site U1418. Both data sets are shown after Gaussian smoothing with a $10 \mathrm{~cm}$ window $( \pm 3 \sigma)$ and interpolation to constant resolution at $2.5 \mathrm{~cm}$. WRMSL MS ( $\kappa$; black) is also shown corrected for variability in recovered sediment volume by normalizing to WRMSL GRA bulk density, generating mass MS ( $\chi$; blue). Data in the upper $238.7 \mathrm{~m}$ CCSF-B reflect the stratigraphic composite splice (see "Stratigraphic correlation"); deeper than 238.7 m CCSF-B, data from XCB and RCB cores in Holes U1418C, $\mathrm{U} 1418 \mathrm{D}$, and $\mathrm{U} 1418 \mathrm{~F}$ are combined to form a single composite section. In this lower portion, we use an average of all available data at depths for which there are overlaps in recovery.

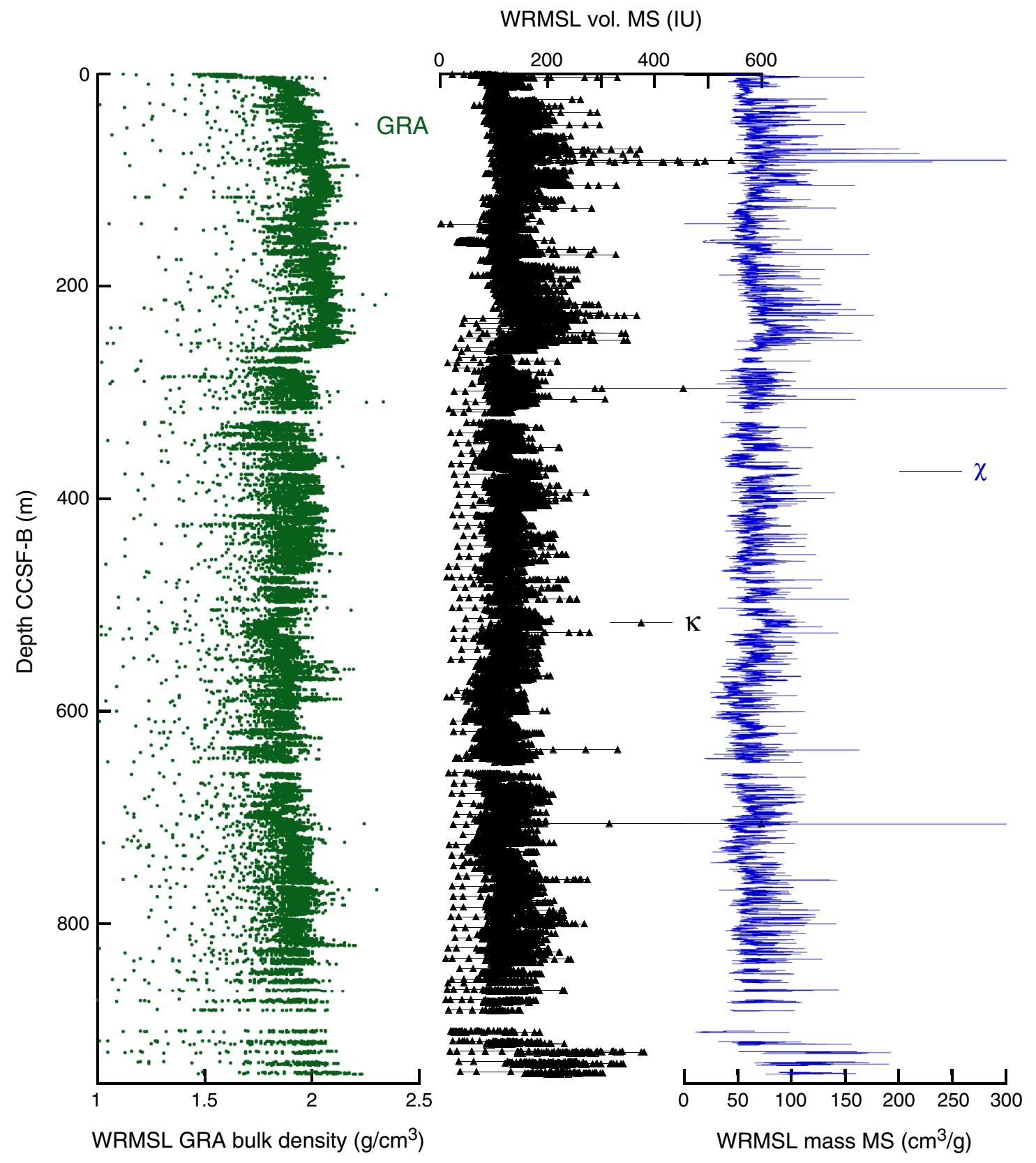


Figure F36. Point-source magnetic susceptibility (MS) data from the APC portions of Holes U1418A-U1418D compared to Whole-Round Multisensor Logger (WRMSL) loop MS data from equivalent depths in those cores.

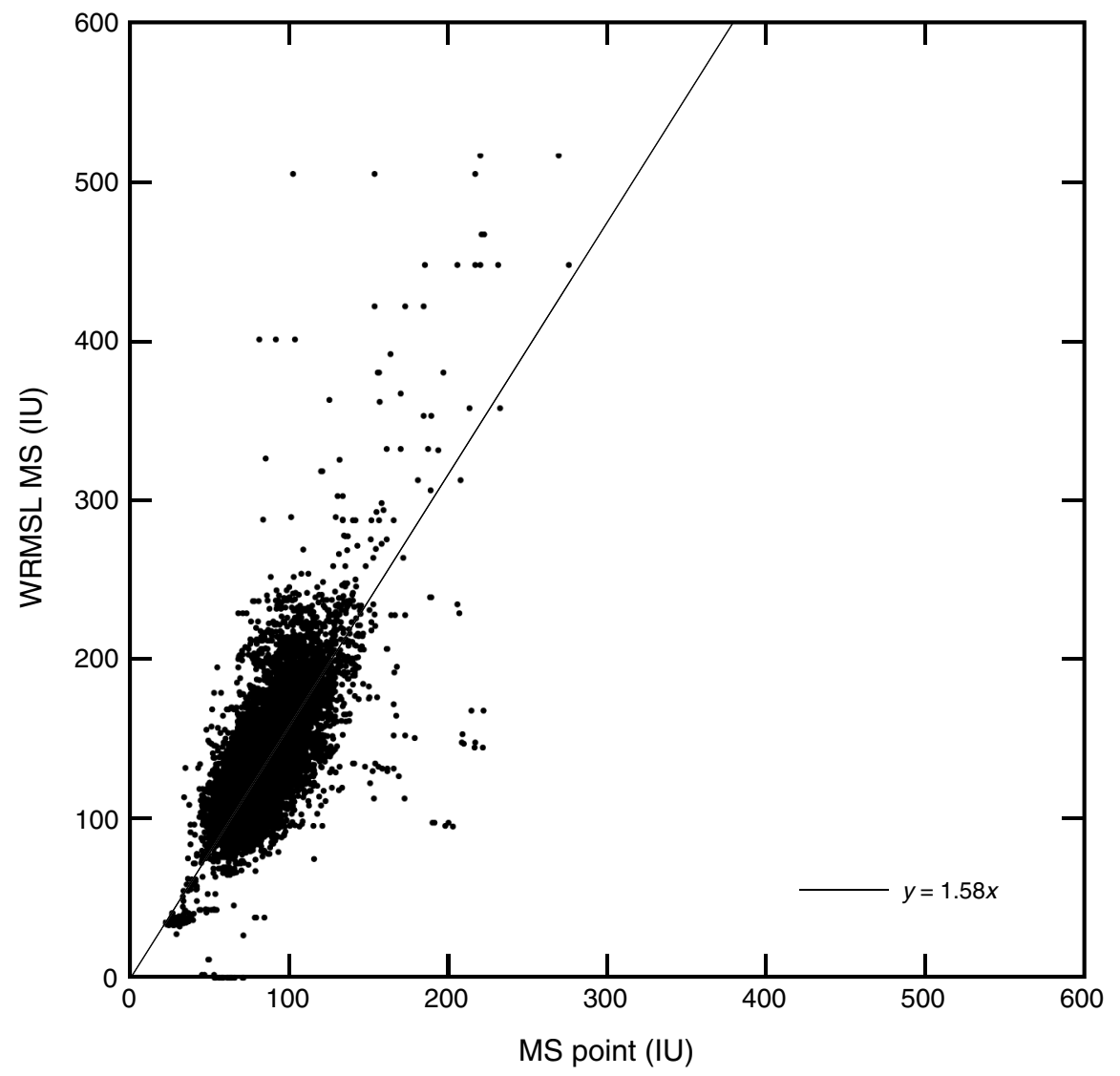


Figure F37. $P$-wave velocity measured by the WRMSL at $2.5 \mathrm{~cm}$ resolution, Holes U1418A-U1418C.

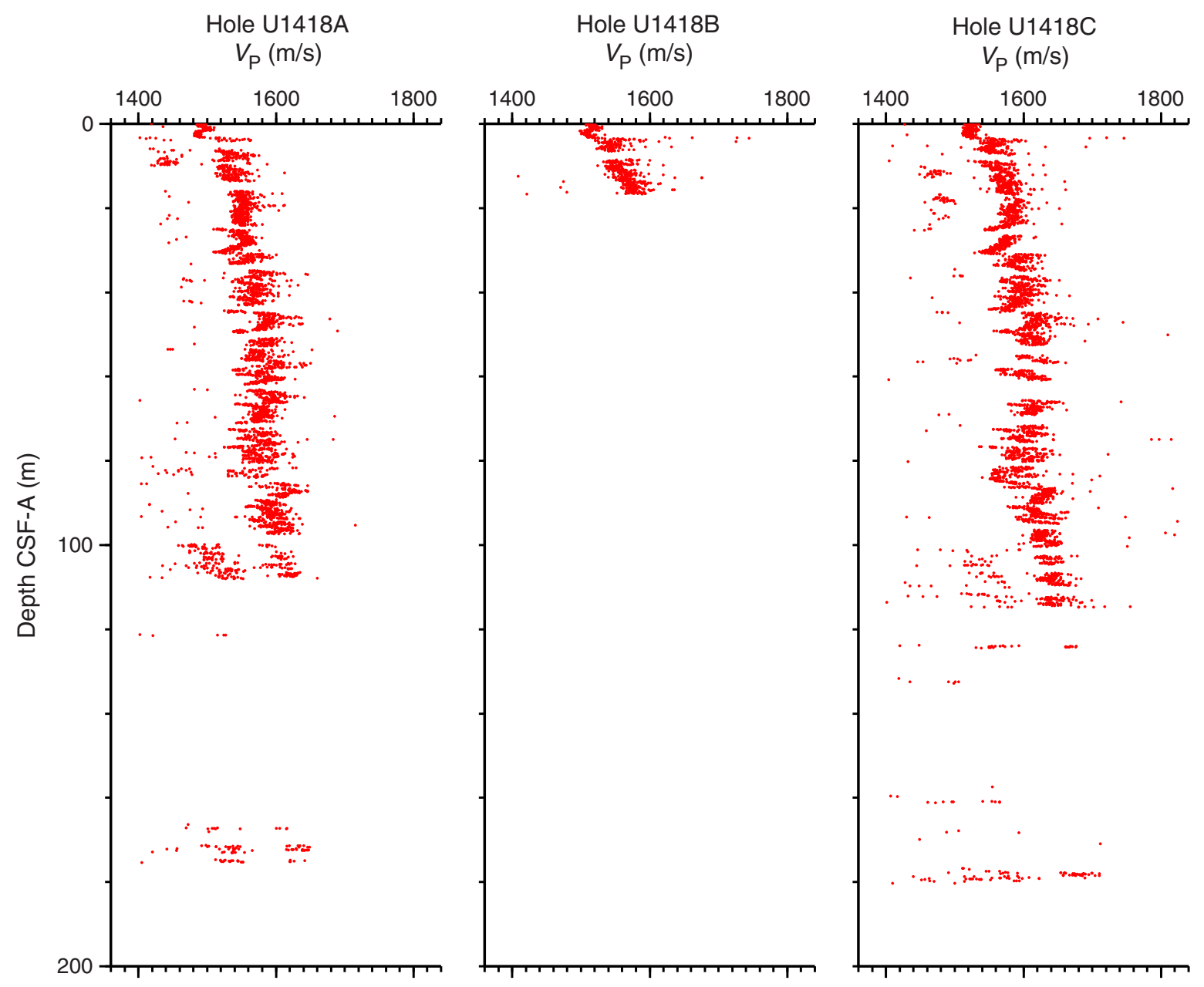


Figure F38. $P$-wave velocity measured by the Whole-Round Multisensor Logger (WRMSL) on whole-round sections and the $P$-wave caliper tool on working half sections. A. Combined plot. B. Scatter plot, showing correlation between track and discrete measurements.

A

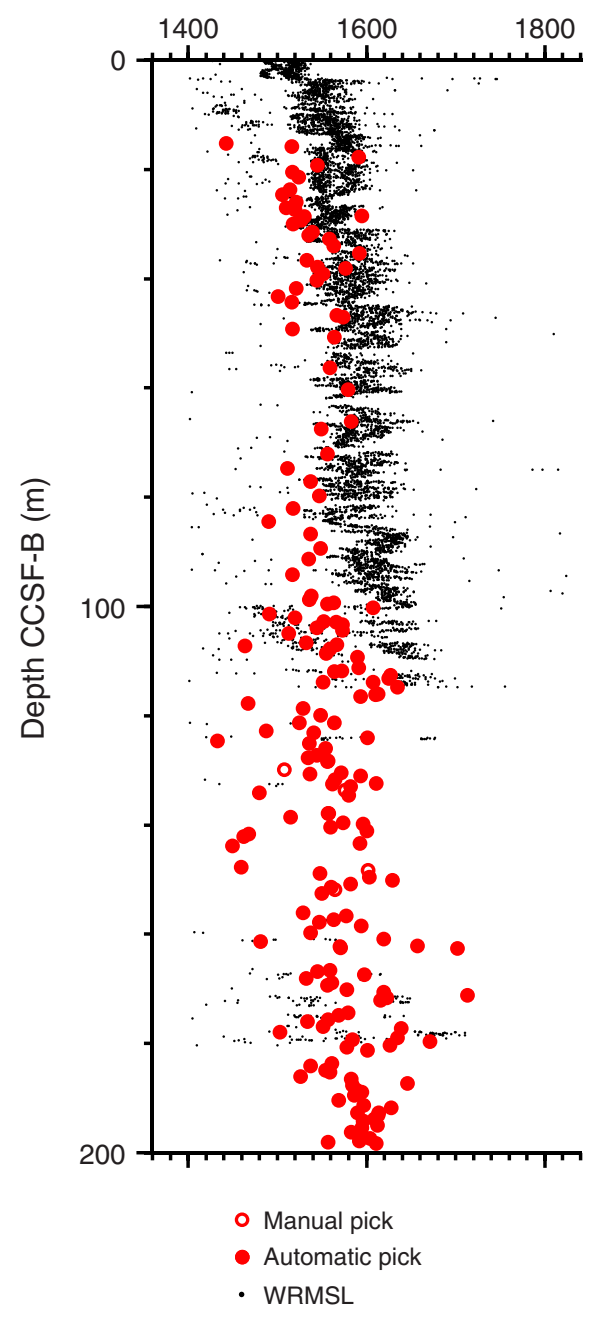

B

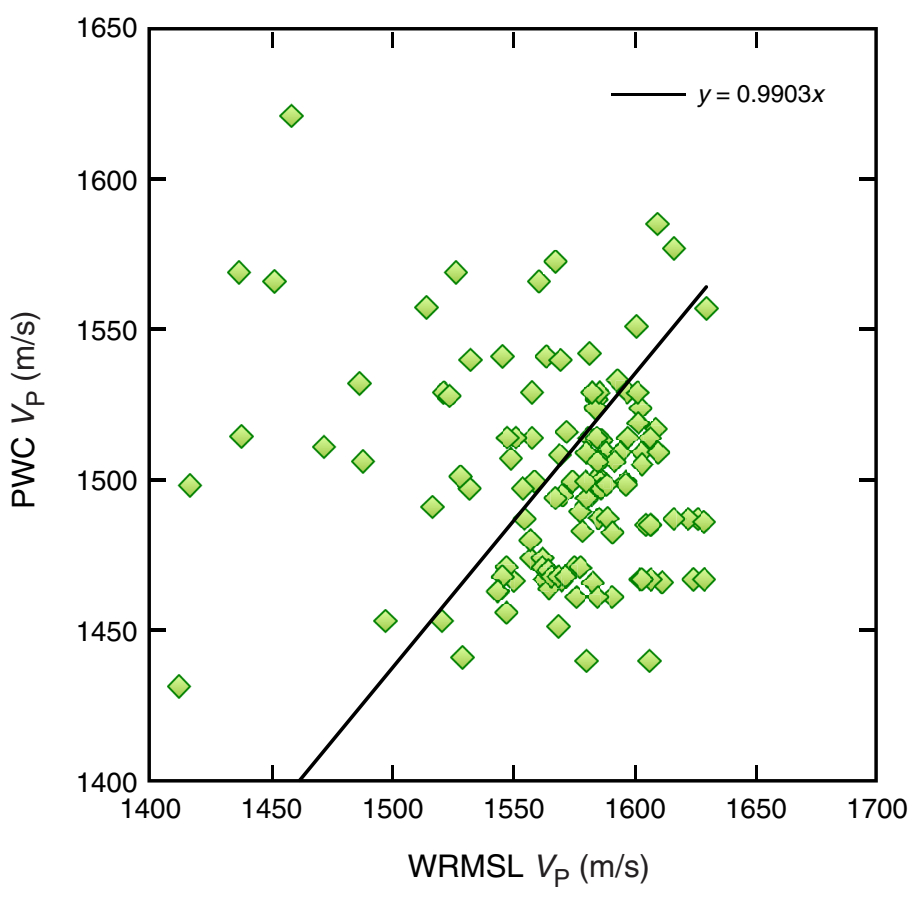


Figure F39. $P$-wave velocity measured by the $P$-wave caliper, Holes U1418A, U1418C, U1418D, and U1418F.

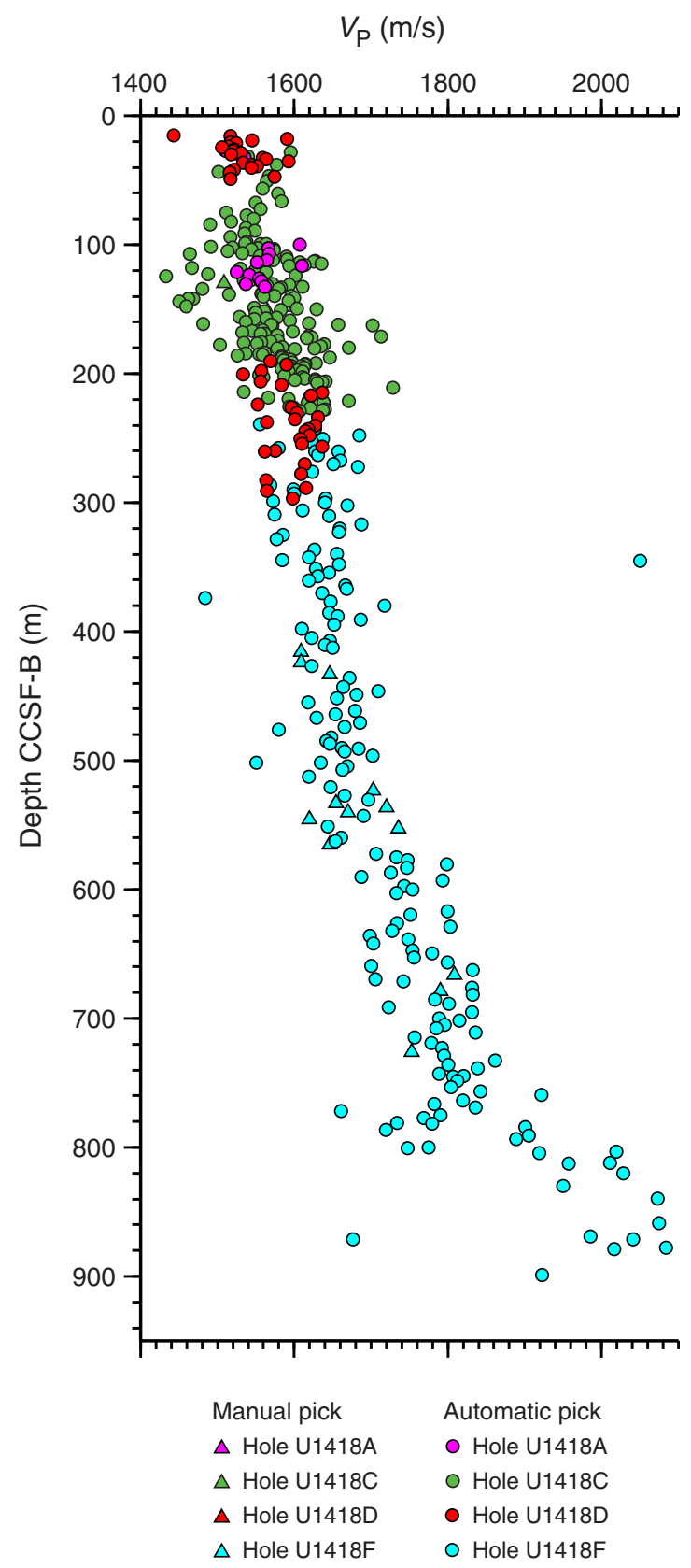


Figure F40. Whole-Round Multisensor Logger (WRMSL) gamma ray attenuation (GRA) bulk density compared to natural gamma radiation (NGR) data, Site U1418. Both data sets are shown after Gaussian smoothing with a $50 \mathrm{~cm}$ window $( \pm 3 \sigma)$ and interpolation to constant resolution at $10 \mathrm{~cm}$. NGR is also shown corrected for variability in recovered sediment volume by normalizing to WRMSL GRA bulk density. Data in the upper $238.7 \mathrm{~m}$ CCSF-B reflect the stratigraphic composite splice (see "Stratigraphic correlation"); deeper than $238.7 \mathrm{~m}$ CCSF$\mathrm{B}$ this point, data from recovered XCB and RCB cores in Holes U1418C, U1418D, and U1418F are combined to form a single composite section. In this lower portion, we use an average of all available data at depths for which there are overlaps in recovery.

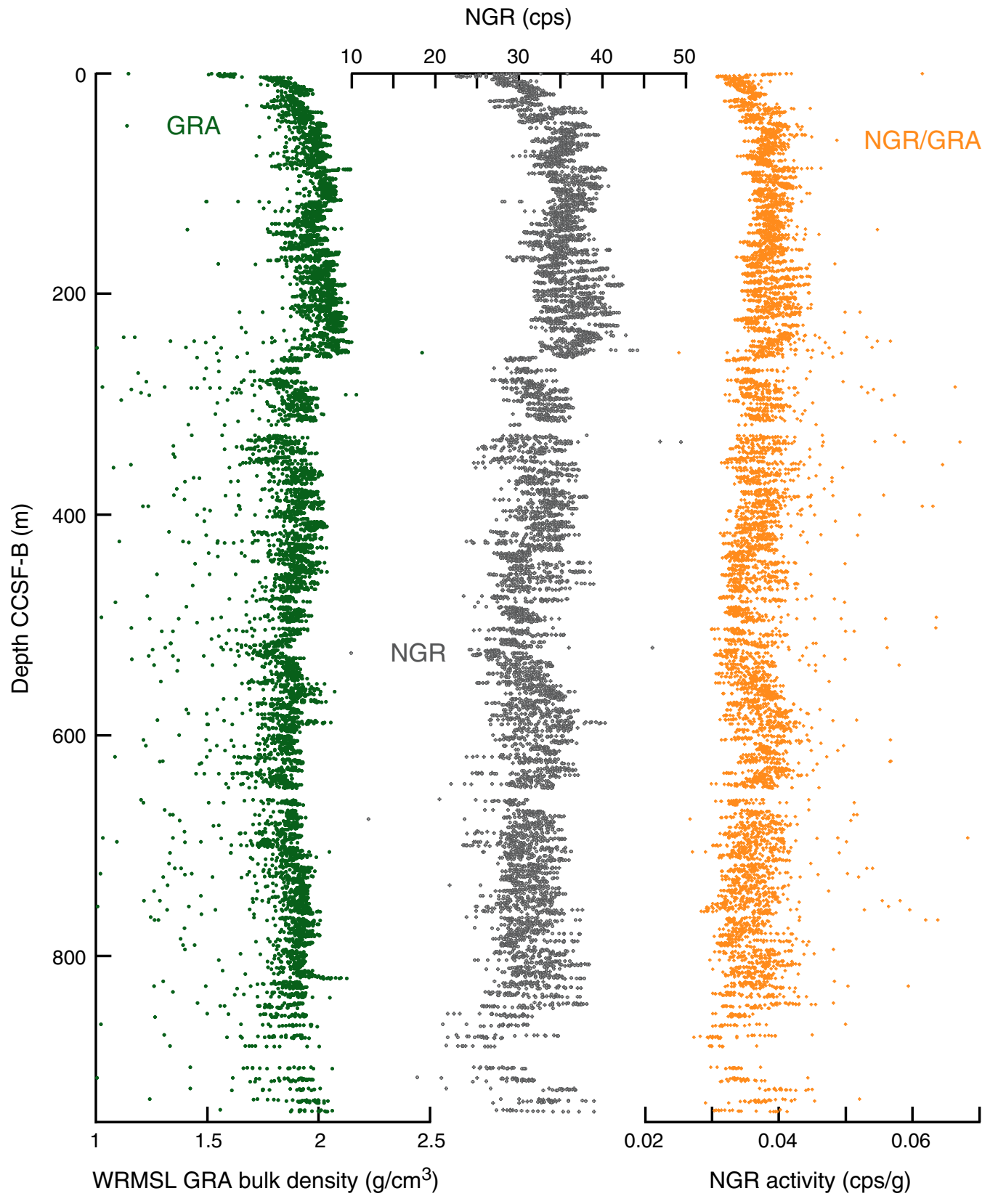


Figure F41. GRA bulk density data measured on the WRMSL (dots) vs. discrete wet bulk density data (circles), Holes U1418A, U1418D, and U1418F.

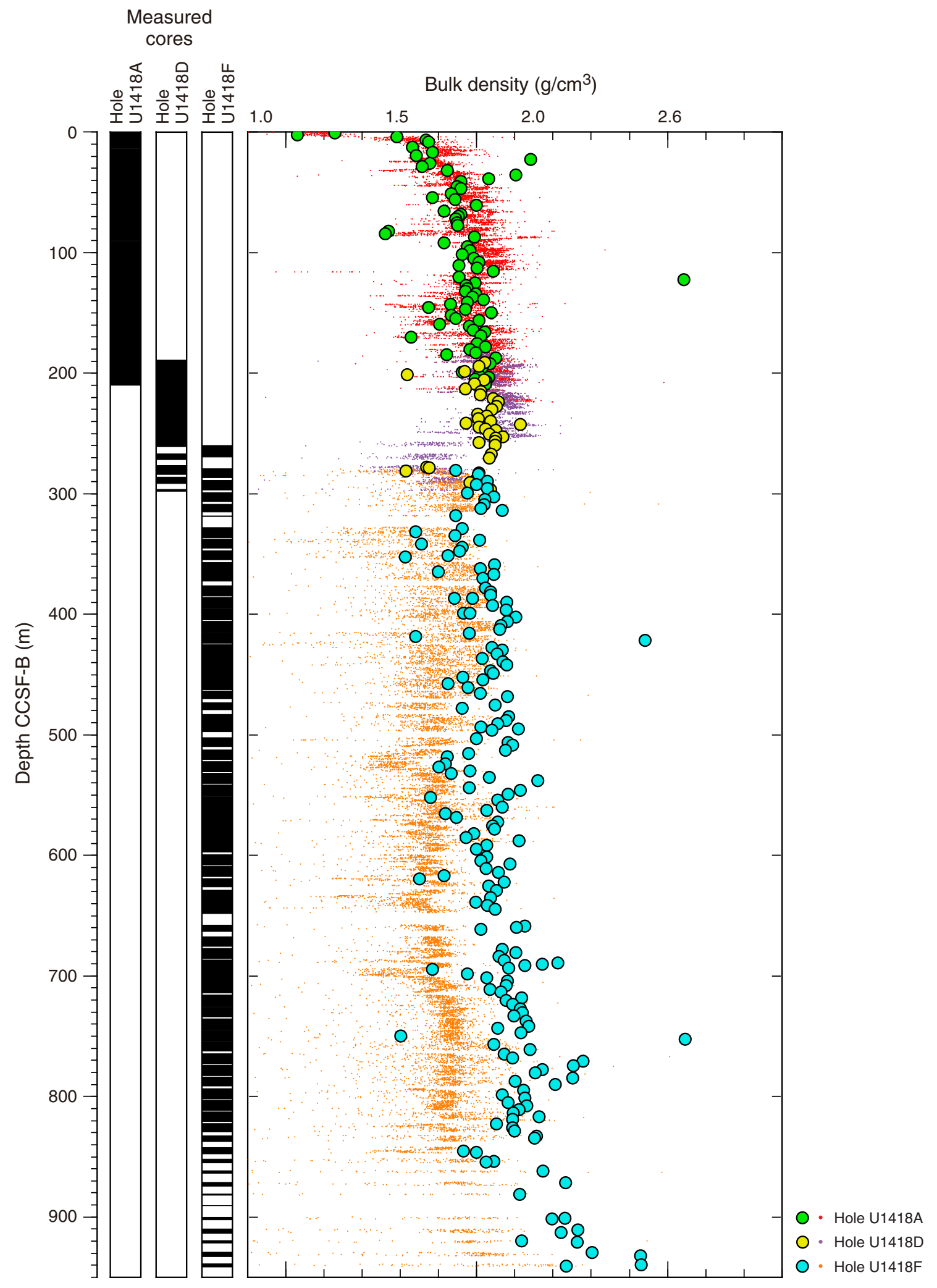


Figure F42. Bulk density, grain density, porosity, and void ratio measured using the moisture and density method, Holes U1418A, U1418D, and U1418F. Circles represent measurements without a denoted lithology, reflecting sampling of the major lithofacies (gray-green mud; see "Lithostratigraphy"). Diatomaceous lithologies are denoted by stars.

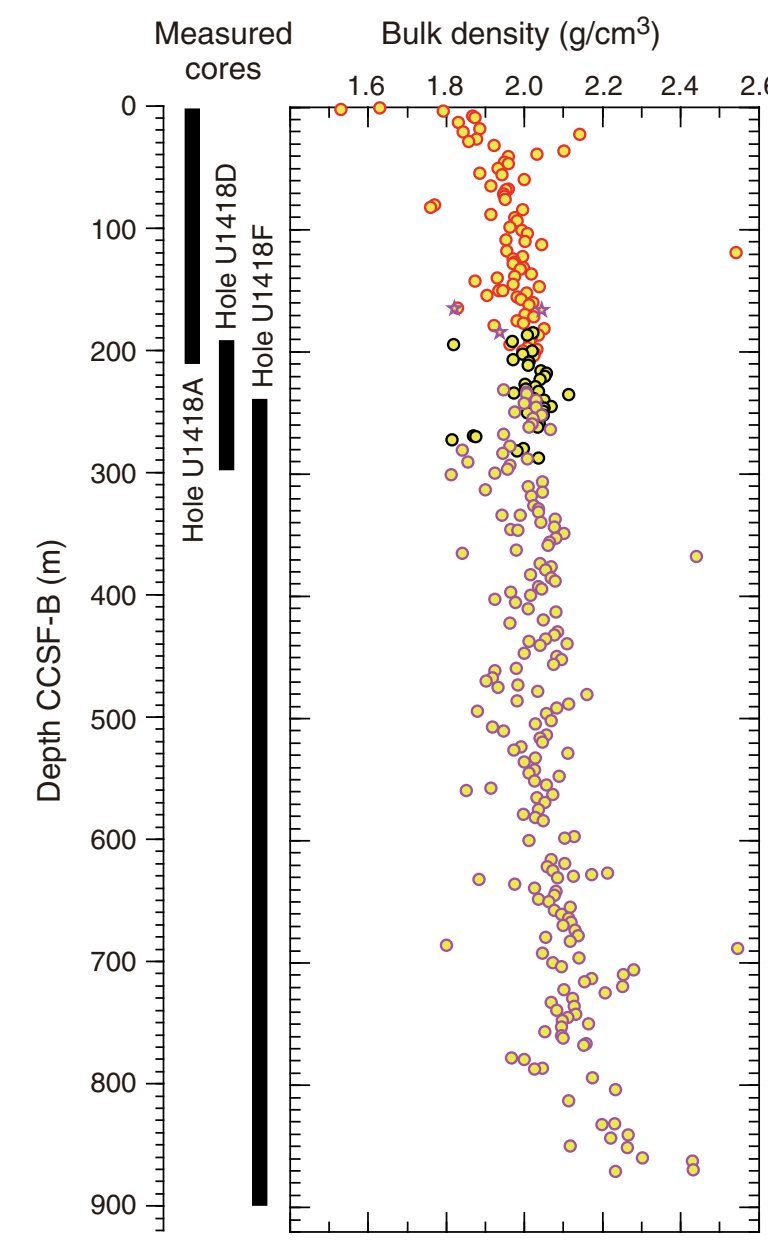

Grain density $\left(\mathrm{g} / \mathrm{cm}^{3}\right)$
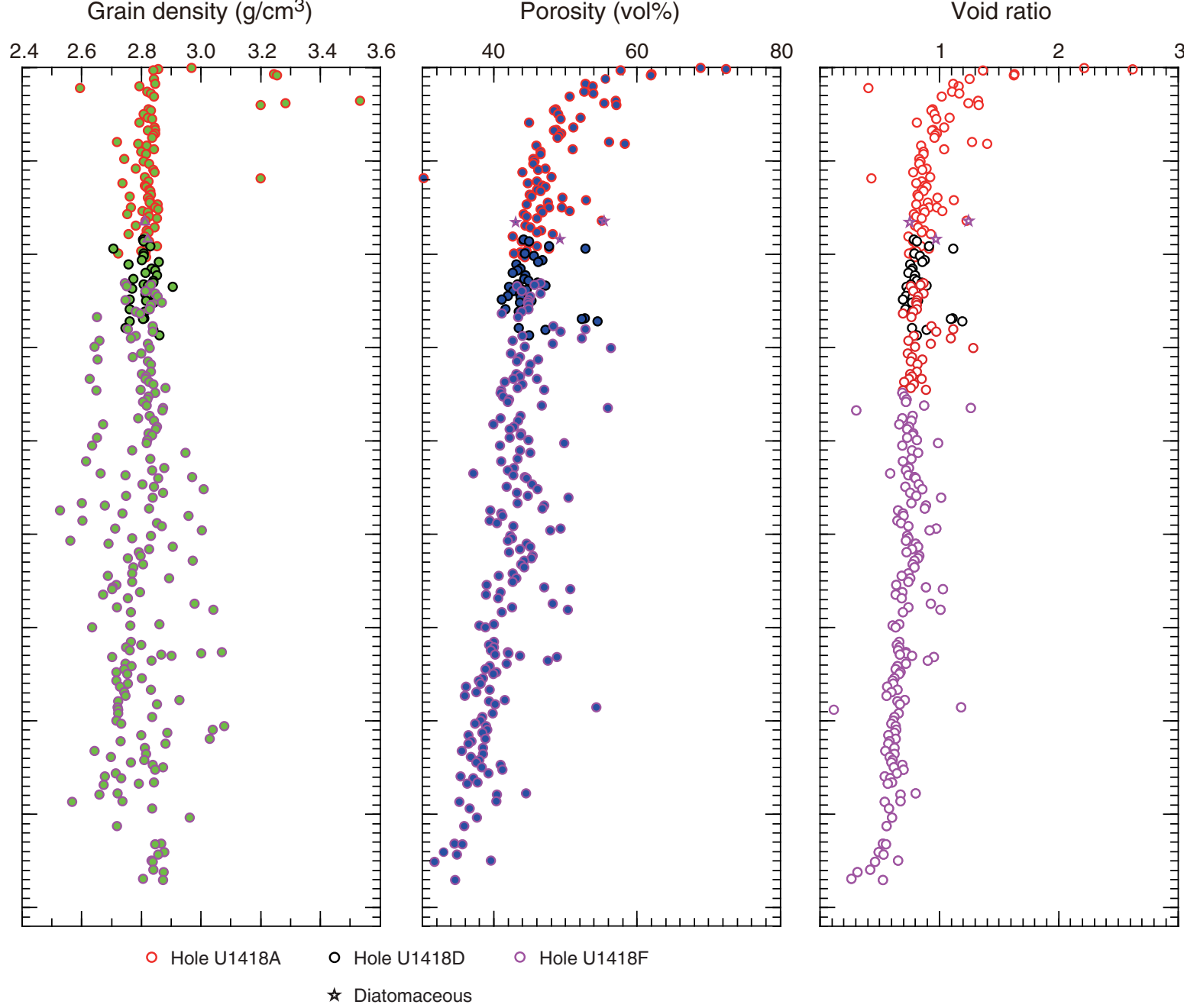
Figure F43. Shear strength values measured by the automatic vane shear system, Holes U1418A and U1418D. Shear strength $(\mathrm{kPa})$

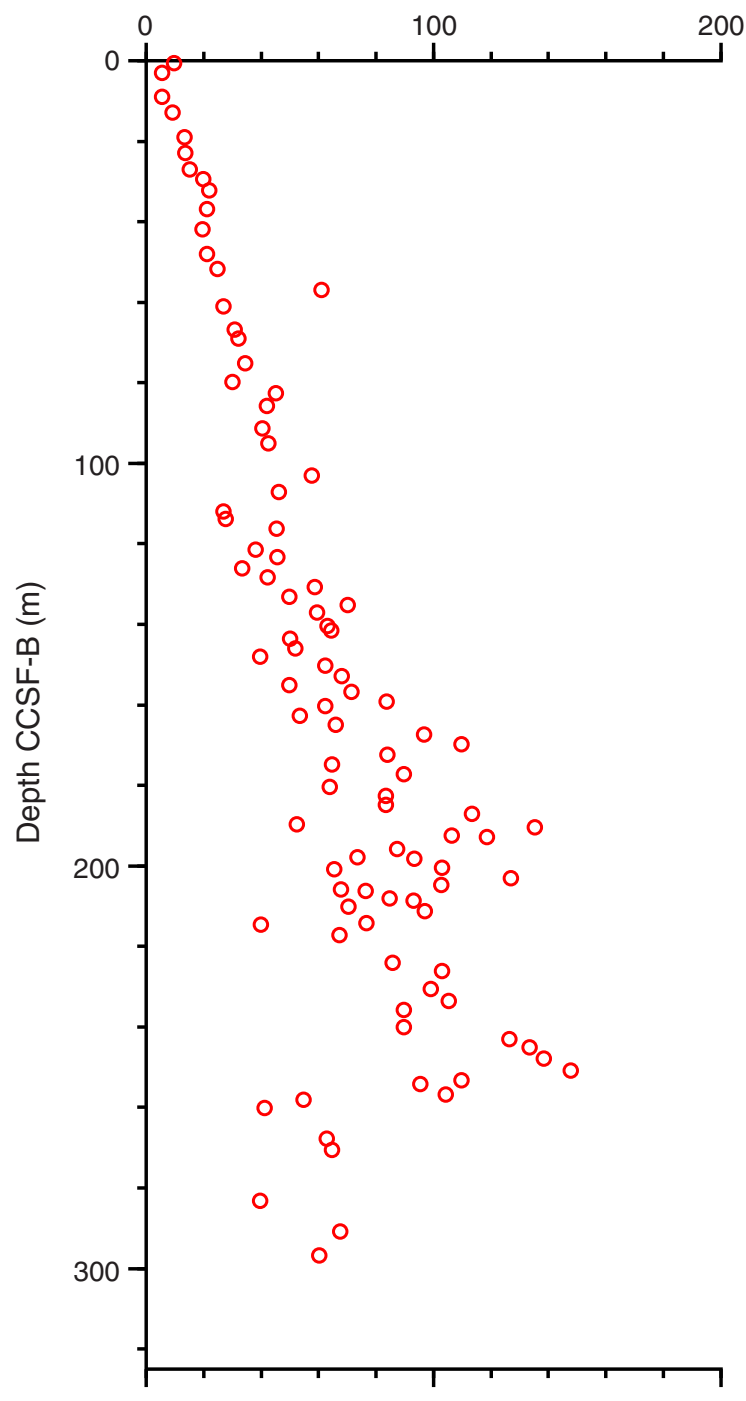


Figure F44. A. Temperature data from the APCT-3, Cores 341-U1418A-4H, 7H, 10H, and 13H. An exponential decrease in temperature is expected for the time interval shown and was used to estimate ambient temperature. Data for the time interval $t_{\mathrm{i}}$ to $t_{\mathrm{f}}$ (solid circles) were used to estimate asymptotic temperature. B. Resulting geothermal gradient $\left(60^{\circ} \mathrm{C} / \mathrm{km}\right)$.

A

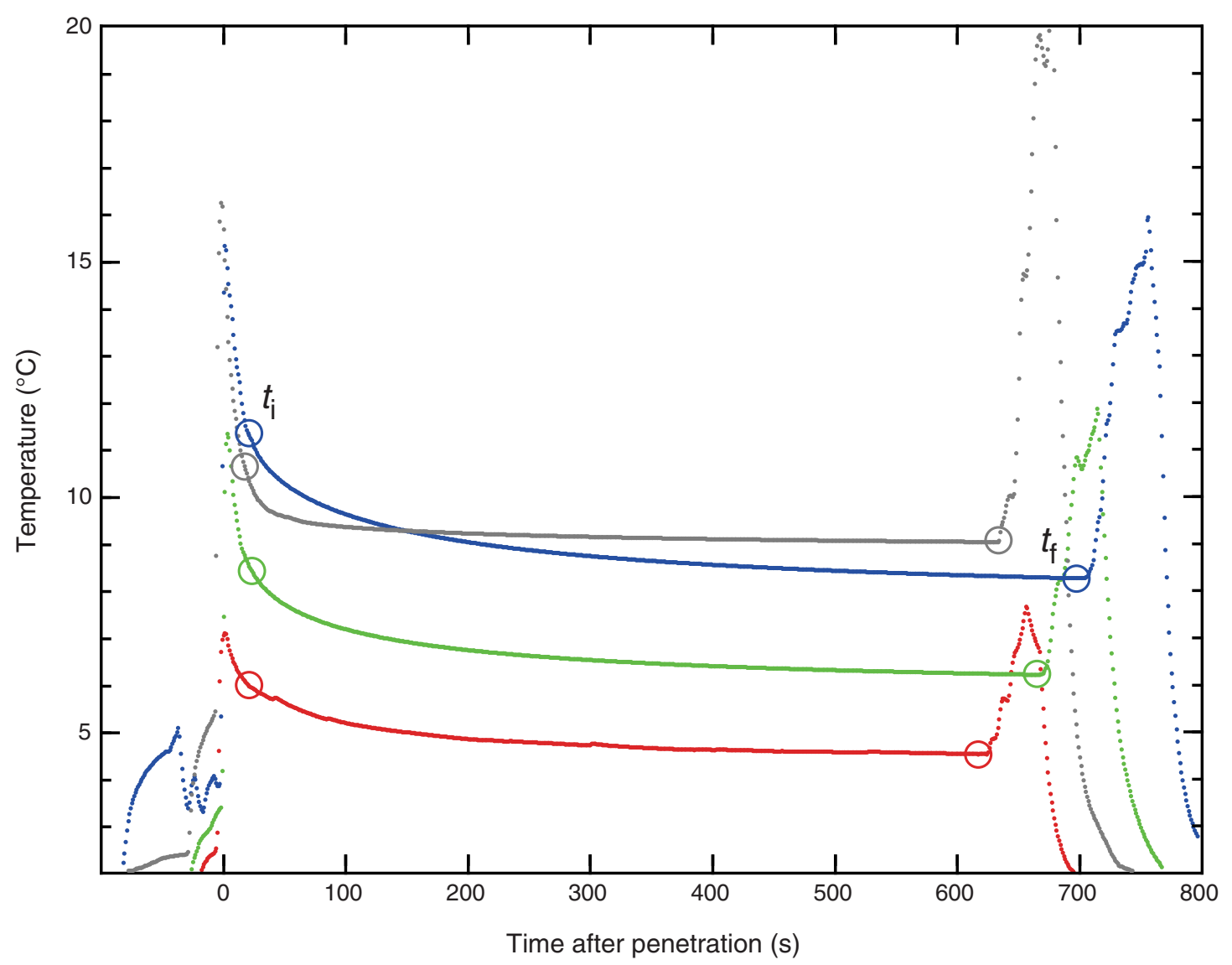

B

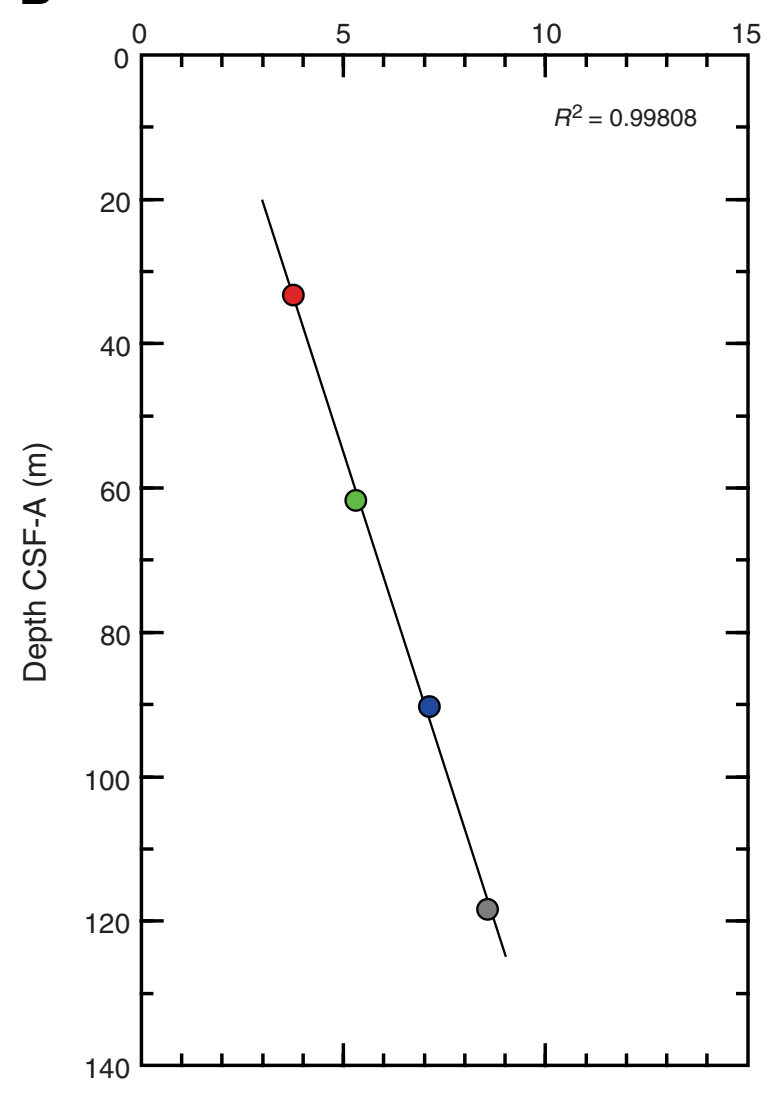

Core 341-U1418A-4H, $33.3 \mathrm{~m}$

Core $341-\mathrm{U} 1418 \mathrm{~A}-10 \mathrm{H}, 90.3 \mathrm{~m}$

-Core 341-U1418A-7H, $61.8 \mathrm{~m}$

- Core 341-U1418A-13H, $118.4 \mathrm{~m}$ 
Figure F45. NRM intensity measured before and after 10 and $20 \mathrm{mT}$ peak AF demagnetization in intervals recovered using the APC, Holes U1418AU1418E.
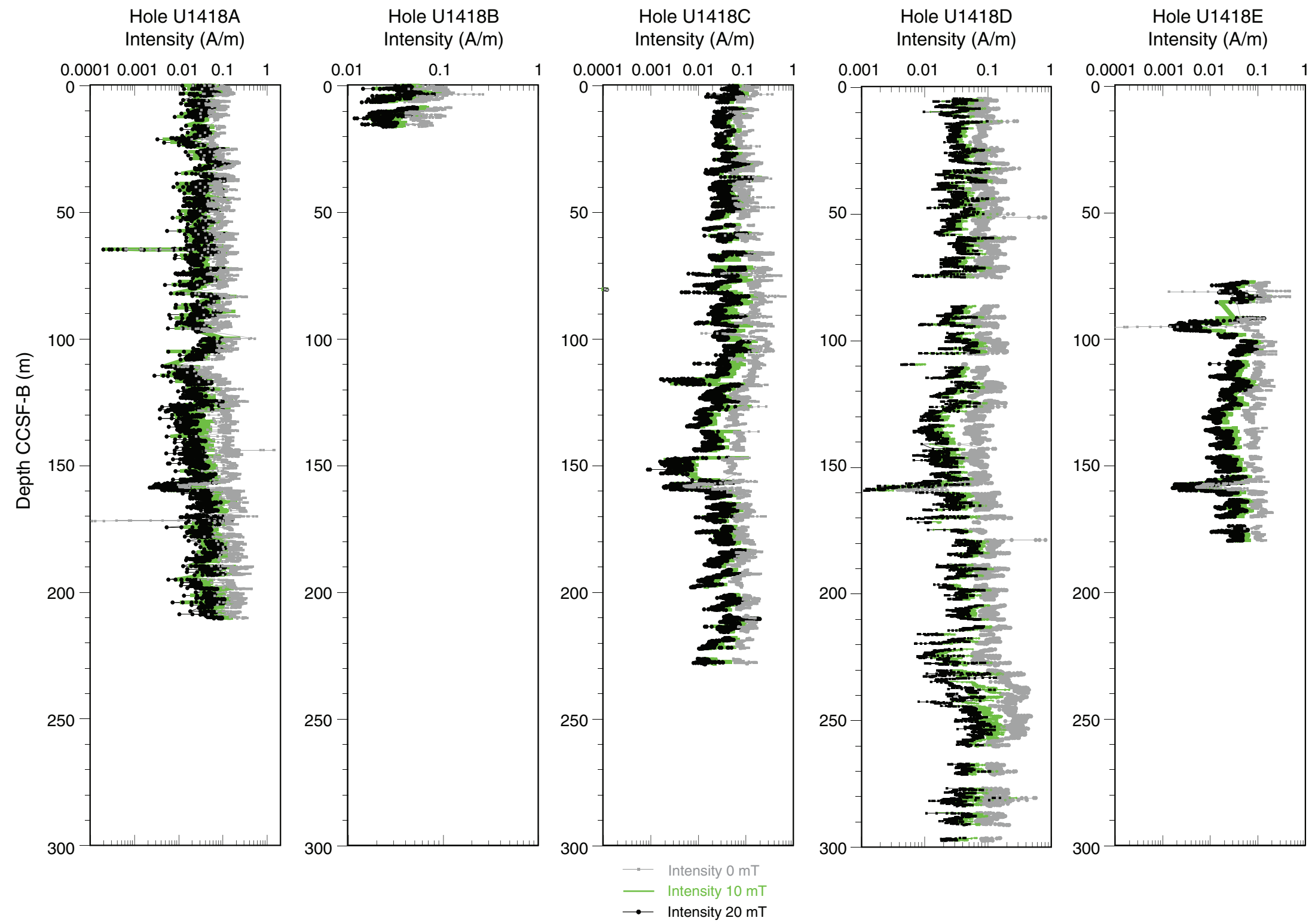
Figure F46. Inclination after $20 \mathrm{mT}$ peak AF demagnetization in intervals recovered using the APC, Holes U1418A-U1418E.
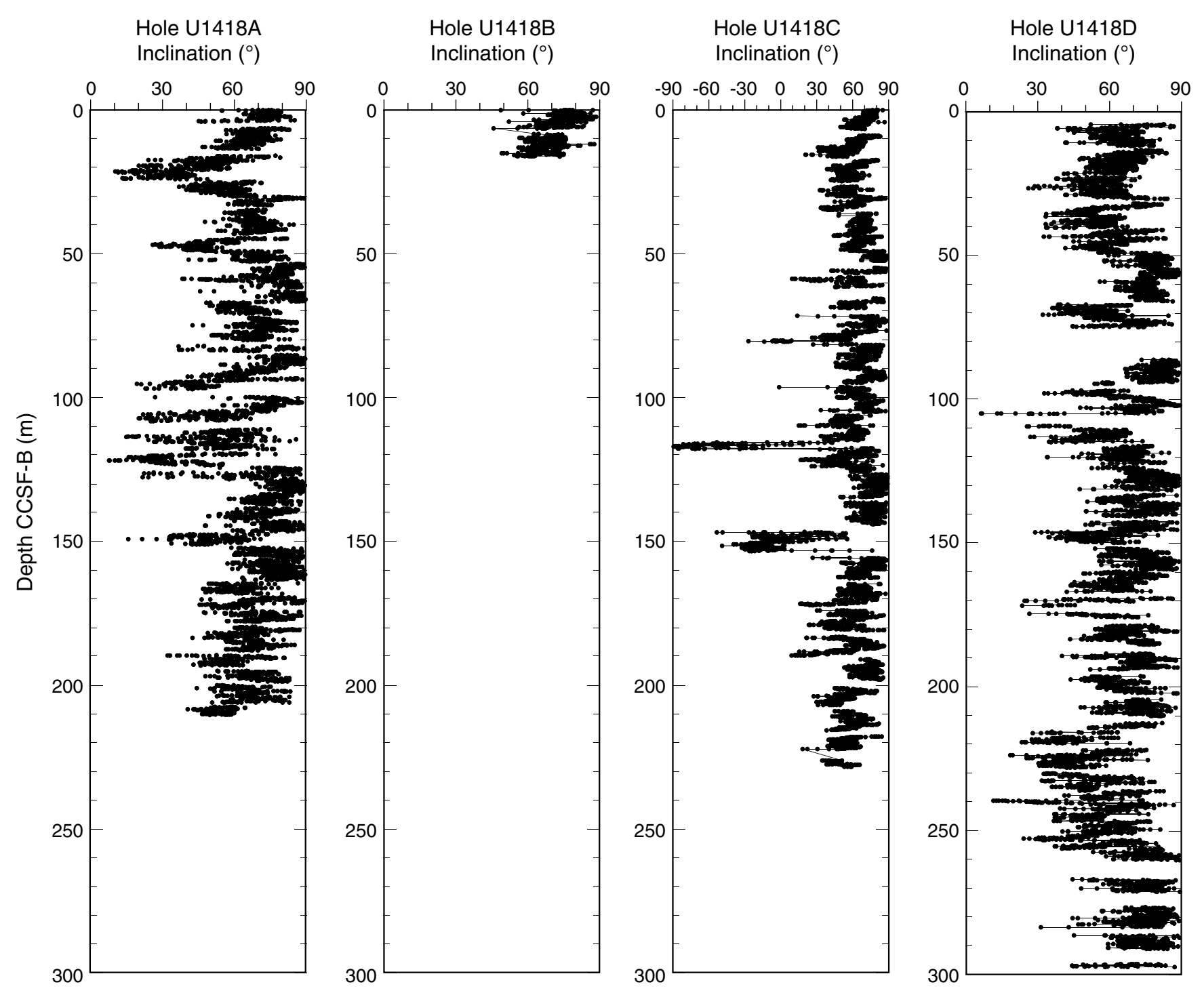

Hole U1418E

Inclination $\left({ }^{\circ}\right)$

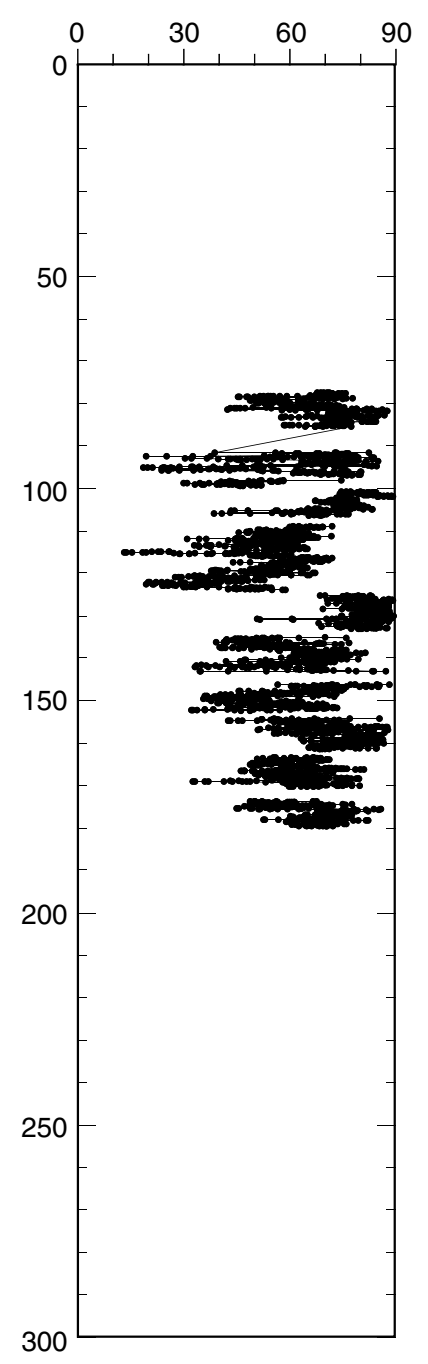


Figure F47. Declination after $20 \mathrm{mT}$ peak AF demagnetization in intervals recovered using the APC, Holes U1418A-U1418E.
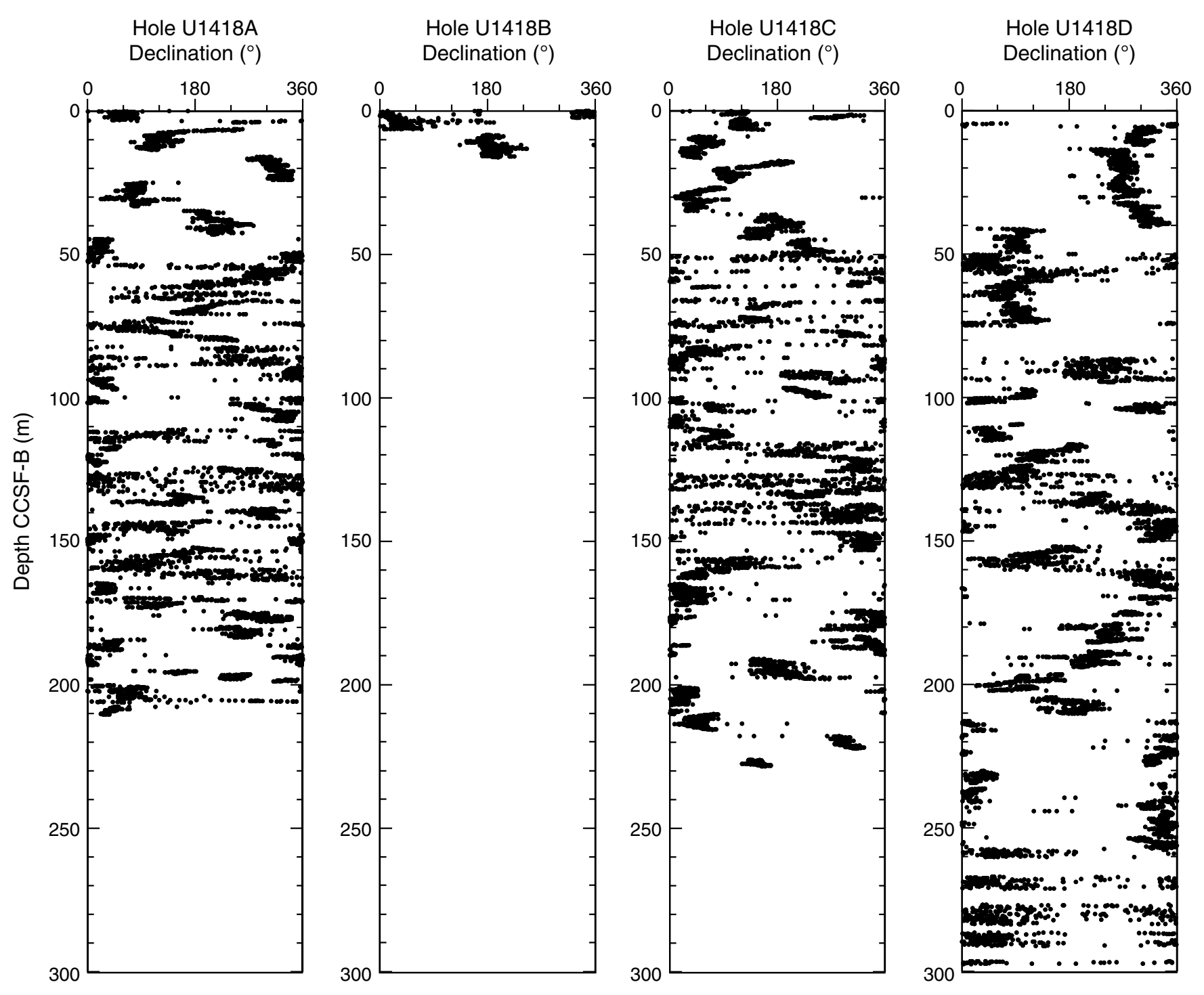

Hole U1418E Declination $\left(^{\circ}\right)$

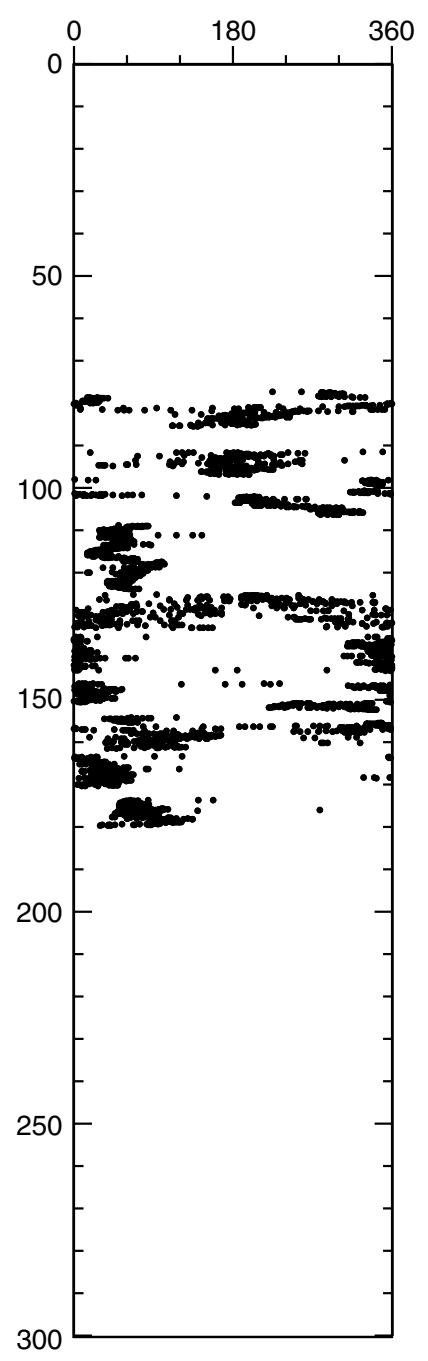


Figure F48. Logging operations summary diagram for Hole U1418F, showing wireline depths reached during different logging passes and borehole depths. See Table T6 in the "Methods" chapter (Jaeger et al., 2014a) for definitions of depth scales. VSP $=$ vertical seismic profile, FMS $=$ Formation MicroScanner.

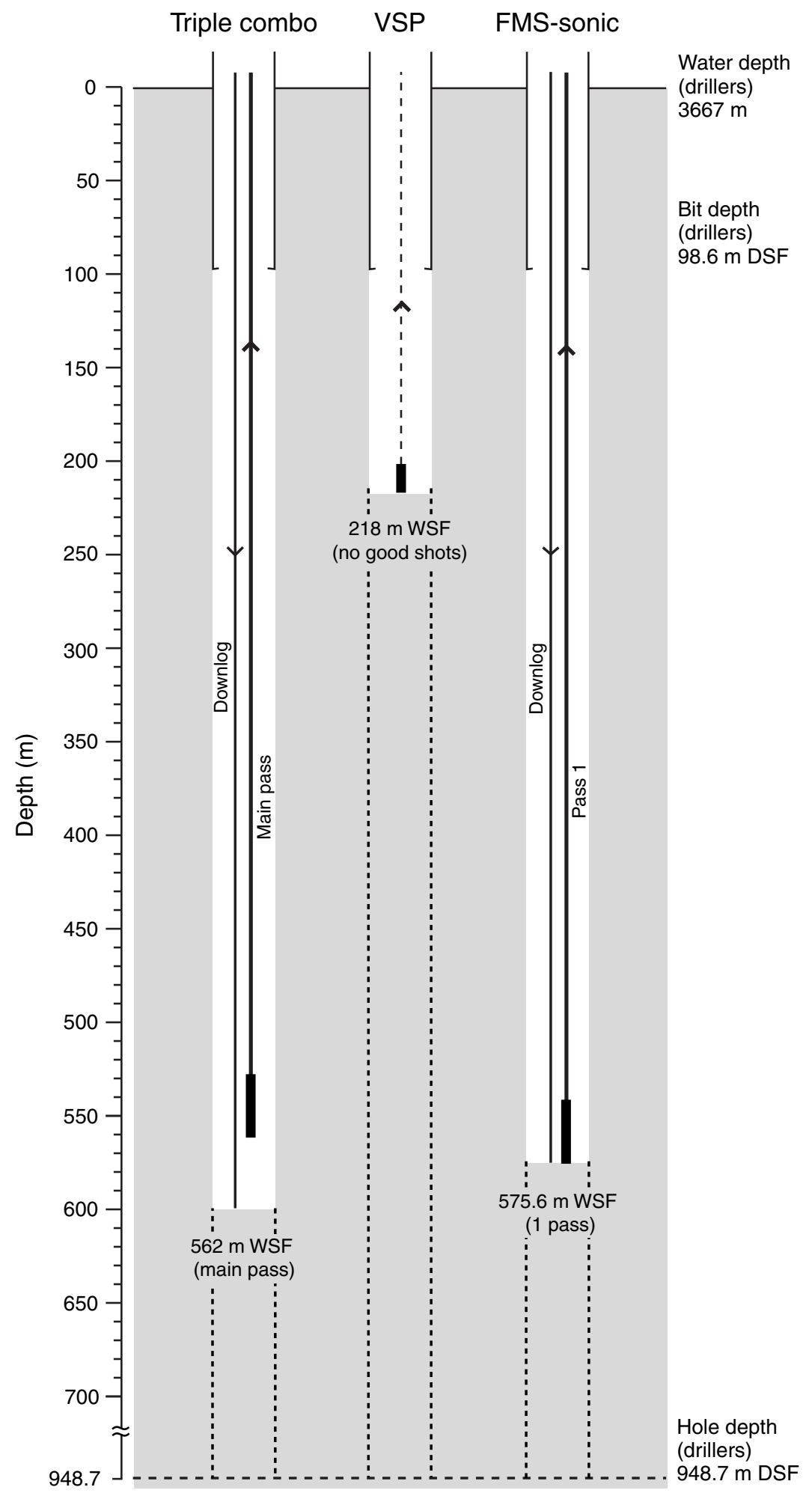


Figure F49. Summary of logs from the triple combo tool string and logging units, Hole U1418F. Core data are plotted in CSF-A. NGR = natural gamma radiation (gray $=$ Hole U1418D, green $=$ Hole U1418F), MAD = moisture and density (open symbols = Hole U1418D, solid symbols = Hole U1418F). Resistivity: R3 = medium resistivity reading of High-Resolution Laterolog Array, R5 = deepest resistivity, RT = true resistivity modeled from all depths. Both originally recorded magnetic susceptibility log and magnetic susceptibility log corrected for internal tool temperature are shown.

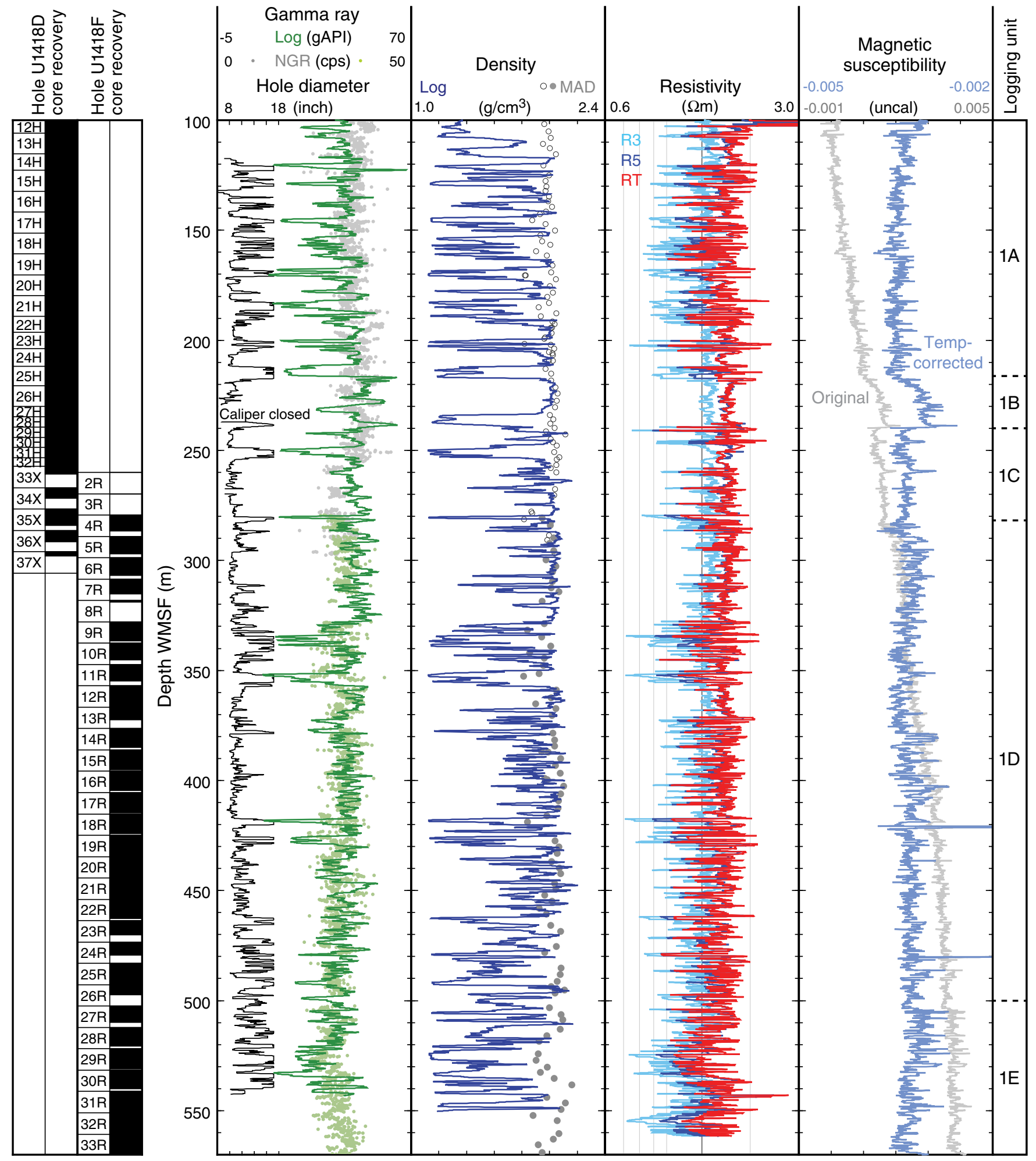


Figure F50. Summary of natural gamma ray logs, Hole U1418F. SGR = standard (total) gamma ray, CGR = computed gamma ray.

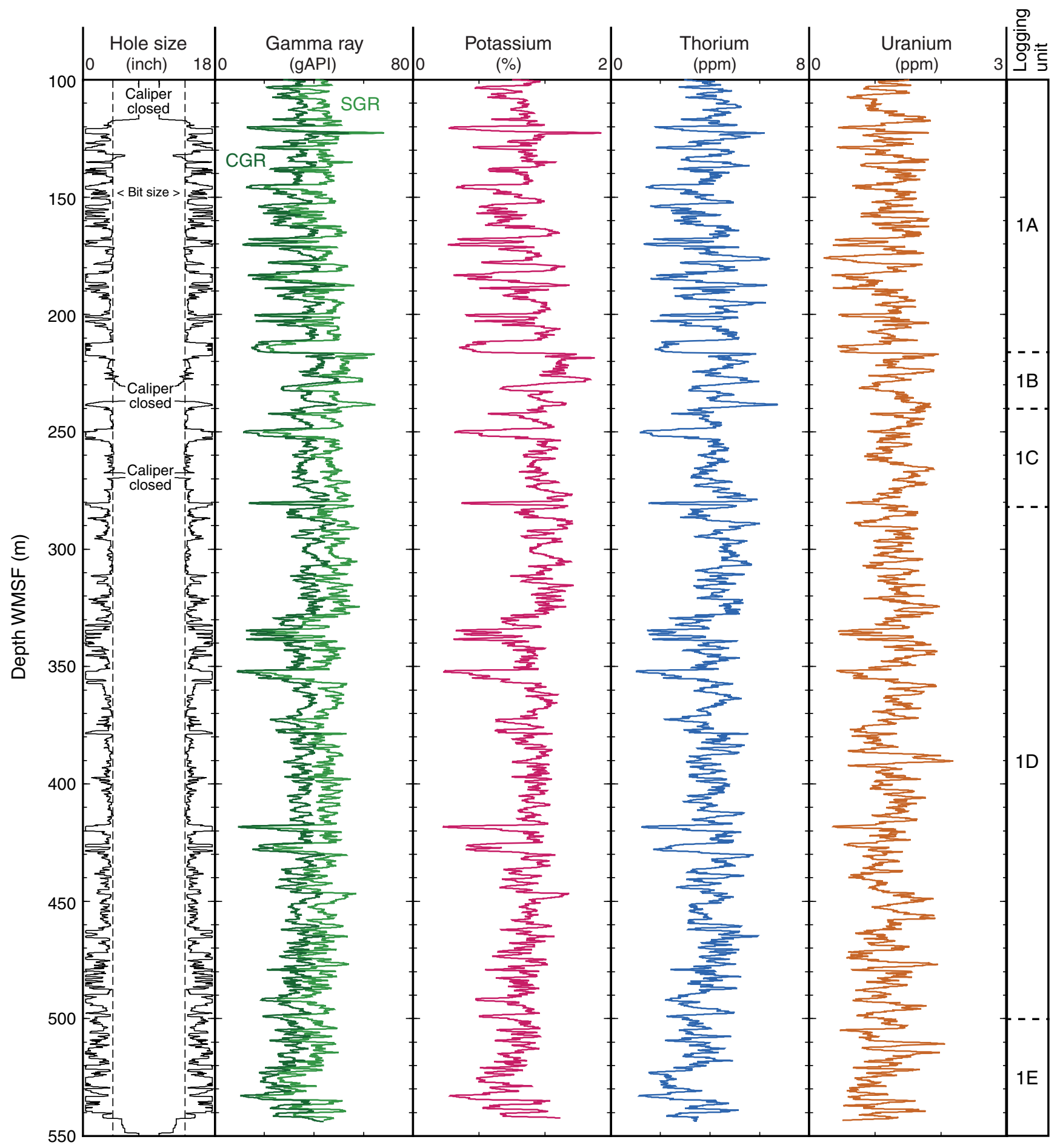


Figure F51. Summary of logs from Pass 1 of the Formation MicroScanner (FMS)-sonic tool string and logging units, Hole U1418F. Hole size is measured by the two orthogonal calipers of the FMS (C1 and C2). Waveform coherence in the velocity tracks is a measure of the reliability of the slowness/time coherence algorithm used to derive compressional $\left(V_{\mathrm{P}}\right)$ and shear $\left(V_{S}\right)$ velocities from monopole and lower dipole sonic waveforms, respectively.

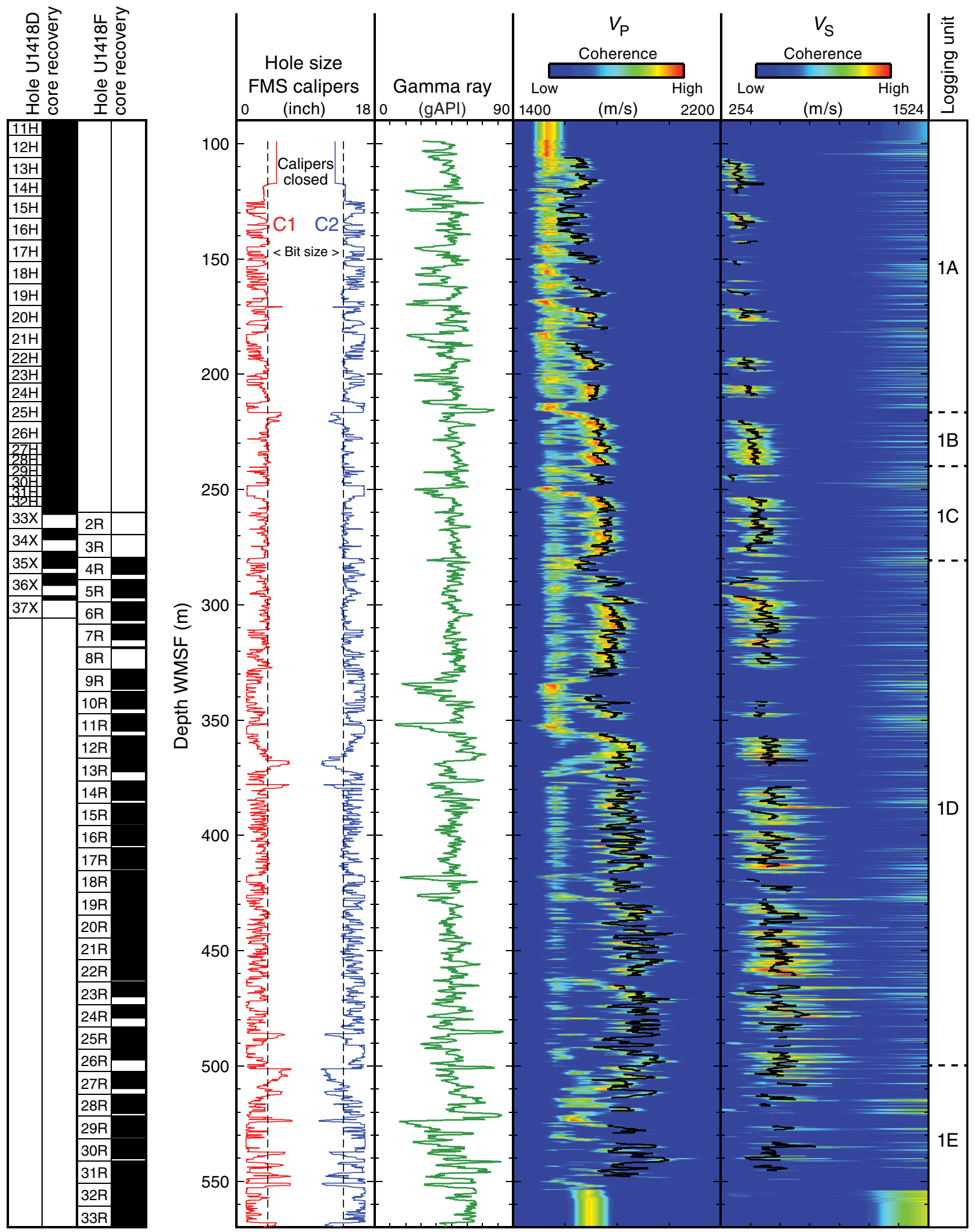


Figure F52. Magnetic susceptibility logs from the Magnetic Susceptibility Sonde deep-reading sensor, Hole U1418F. Data from Hole U1417E shown for comparison of temperature effect on sensor. Based on the similarity between the linear increases in tool temperature during the triple combo main pass in these two holes, the same corrective factor was applied to the originally recorded logs to remove the increasing trend with depth attributed to temperature. T-corrected $=$ temperature-corrected.

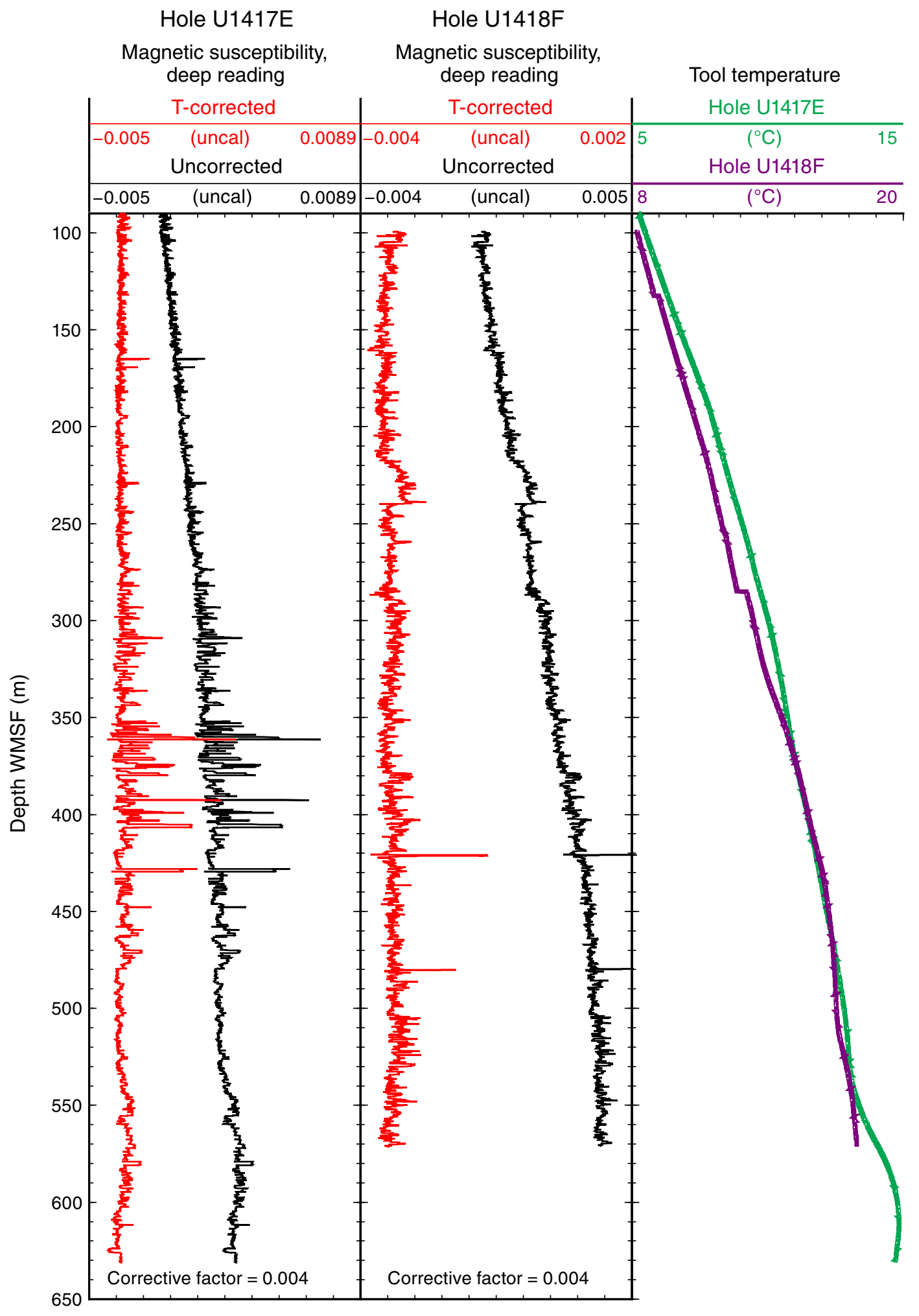


Figure F53. Natural gamma ray, hole diameter, magnetic susceptibility, resistivity, and Formation MicroScanner (FMS) images for 290-330 m WMSF (within logging Subunit 1D), Hole U1418F. Images may appear out of focus as a result of variability in borehole size, which makes it difficult for FMS pads to maintain good contact with the borehole wall.

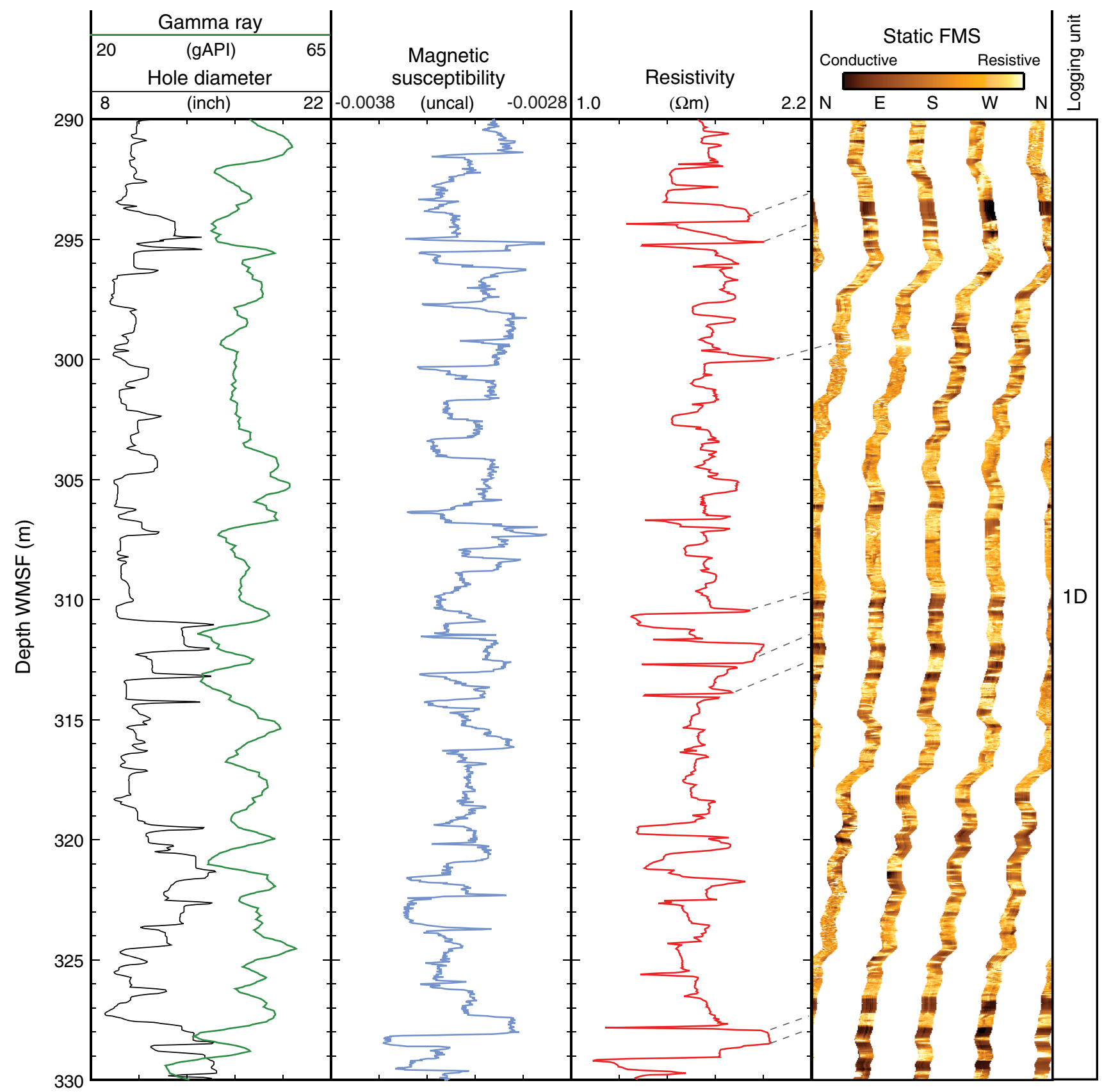


Figure F54. A. Example of multiple clasts (high-resistivity features at $210.5 \mathrm{~m}$ WMSF) in a Formation MicroScanner (FMS) image, Hole U1418F. B. Clast in a core photograph (interval U1418D-24H-3A, 90-140 cm). Although these are different clasts, these log and core features are likely from the same clast-rich interval at Site U1418.

A

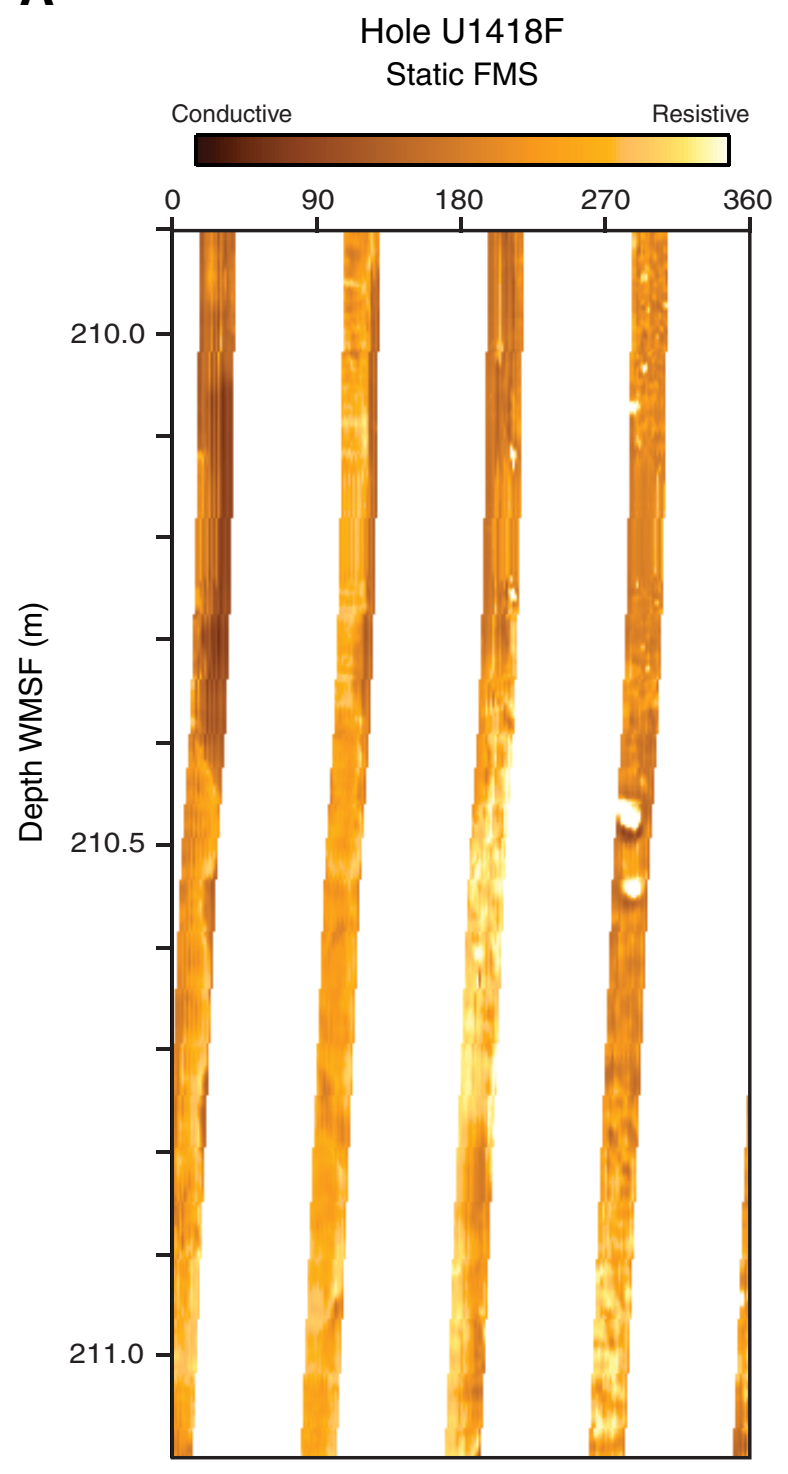

B

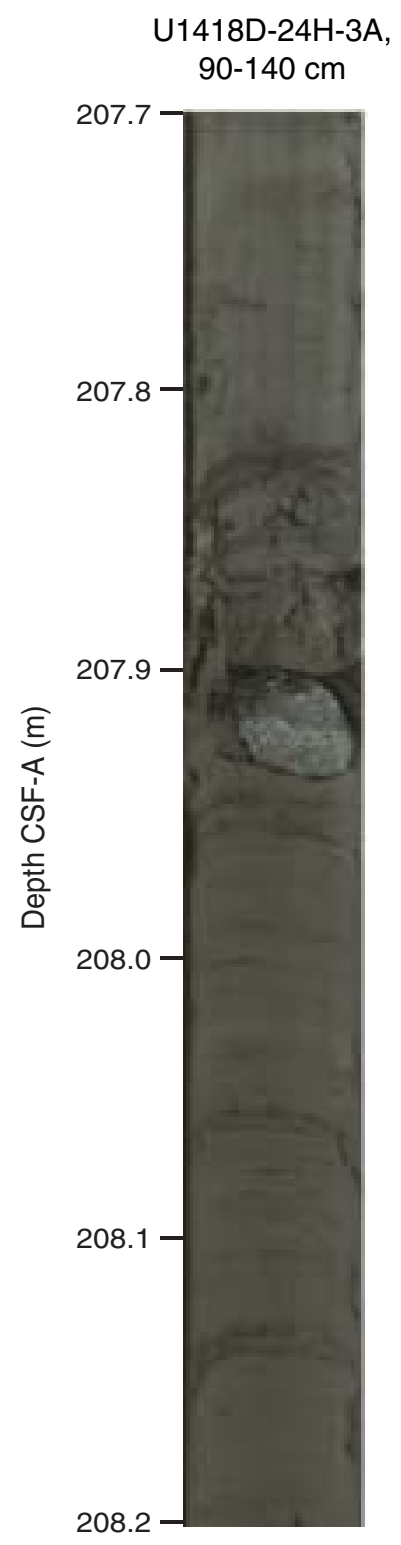


Figure F55. Comparison of core and logging magnetic susceptibility (MS), Site U1418. Diamict, diatom ooze, diatom-rich mud, laminations, and bioturbation are combined observations from Holes U1418A-U1418F and are compared to MS data measured during downhole logging in Hole U1418F (blue curve) and on cores (purple curve from integrated measurements made on splices). Downhole logging MS data are smoothed over a $40 \mathrm{~cm}$ sliding average and are temperature corrected (T-corrected). Core MS has been smoothed over a $2.5 \mathrm{~cm}$ window and then volumetrically corrected. The inset diagram shows the close correspondence between core and logging MS between 100 and 225 m CCSF-B/WMSF.

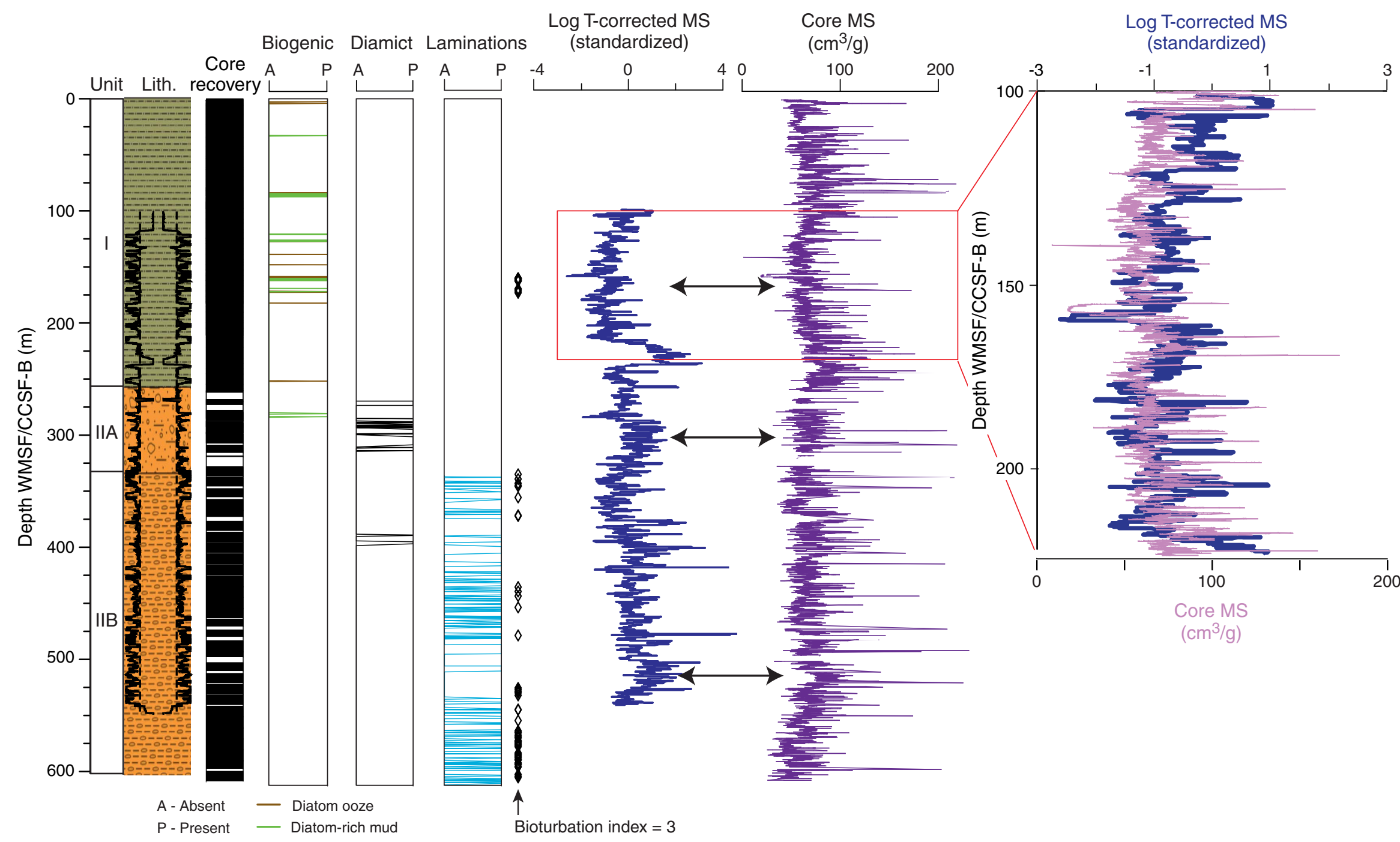


Figure F56. Logging gamma radiation, Site U1418. Diatom ooze, diatom-rich mud, mud with clasts, and bioturbation are combined observations from Holes U1418A and U1418C-U1418F and are compared to natural and spectral gamma radiation measured during downhole logging with the triple combo (TC) and Formation MicroScanner (FMS)-sonic tool strings. Gamma ray measurements from the FMS-sonic (black curves) are superposed to gamma ray measurements from the triple combo (colored curves) to highlight reproducibility and coherency between the different passes.

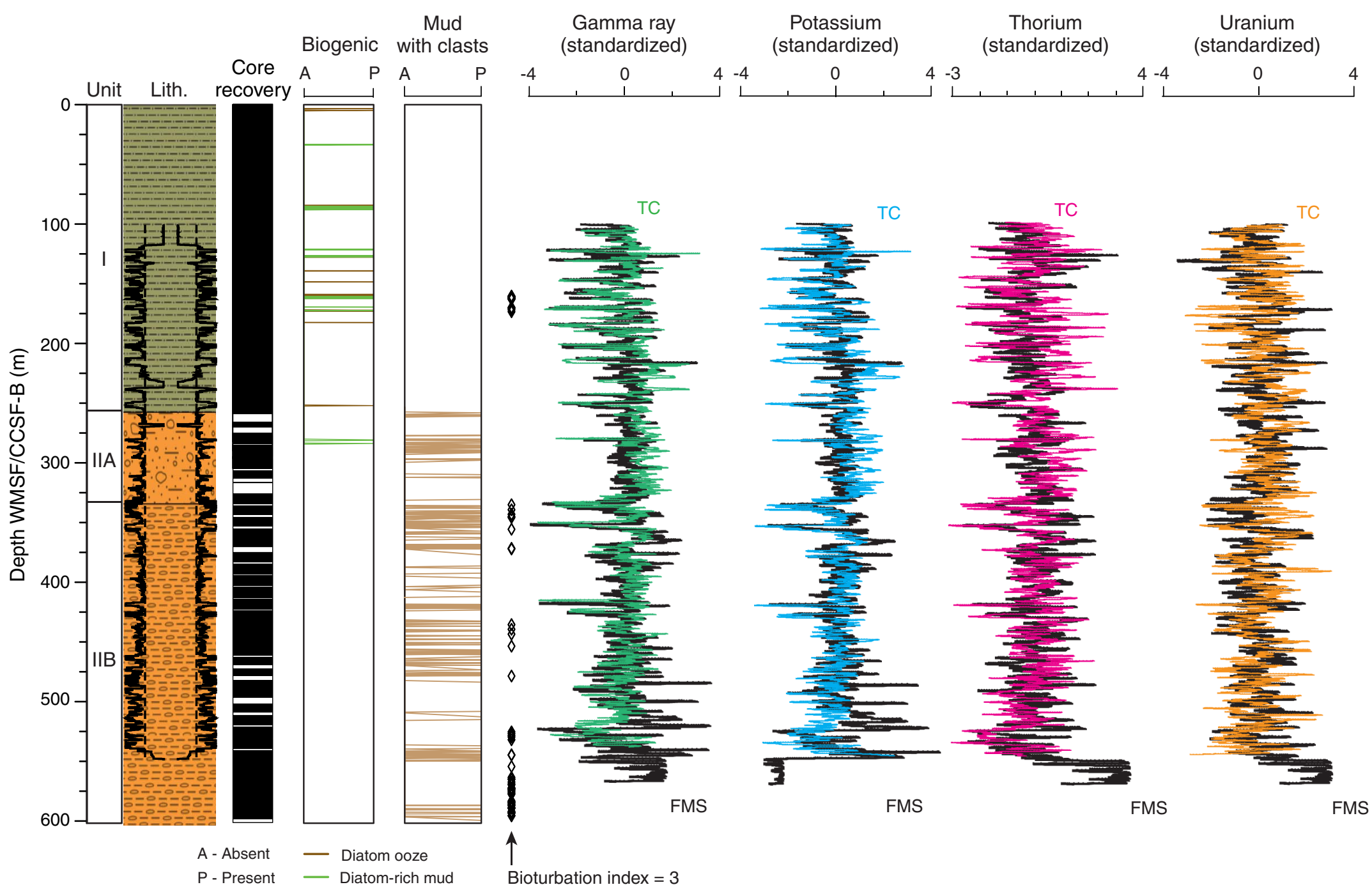


Figure F57. Downhole wireline logging data, Hole U1418F, and core physical properties data, Site U1418. Core natural gamma radiation (NGR) is volume corrected. MAD = moisture and density, GRA = gamma ray attenuation. Core $P$-wave data: closed symbols $=$ automatic velocity picks, open symbols $=$ manual velocity picks. Tcorr $=$ temperature corrected. Core magnetic susceptibility (MS) data are volume corrected. See text for details.

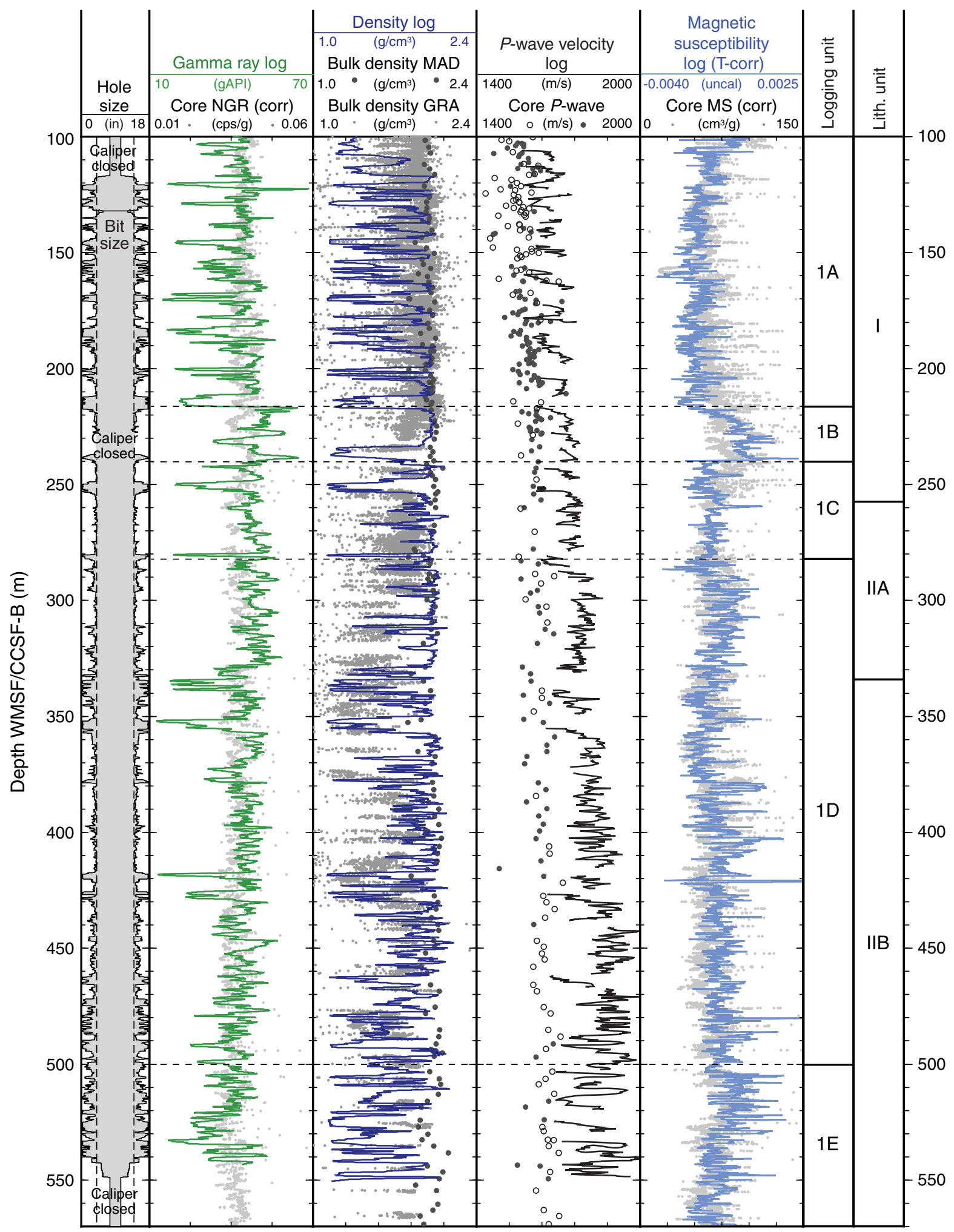


Figure F58. High-resolution ( $\sim 5 \mathrm{~m}$ vertical resolution at seafloor) seismic Profile GOA3202 acquired in 2004 aboard the R/V Maurice Ewing. Seismic Sequence III interpreted after Reece et al. (2011). Sequences IIIA, IIIB, IIIC, and II* defined as units here for correlation purposes.

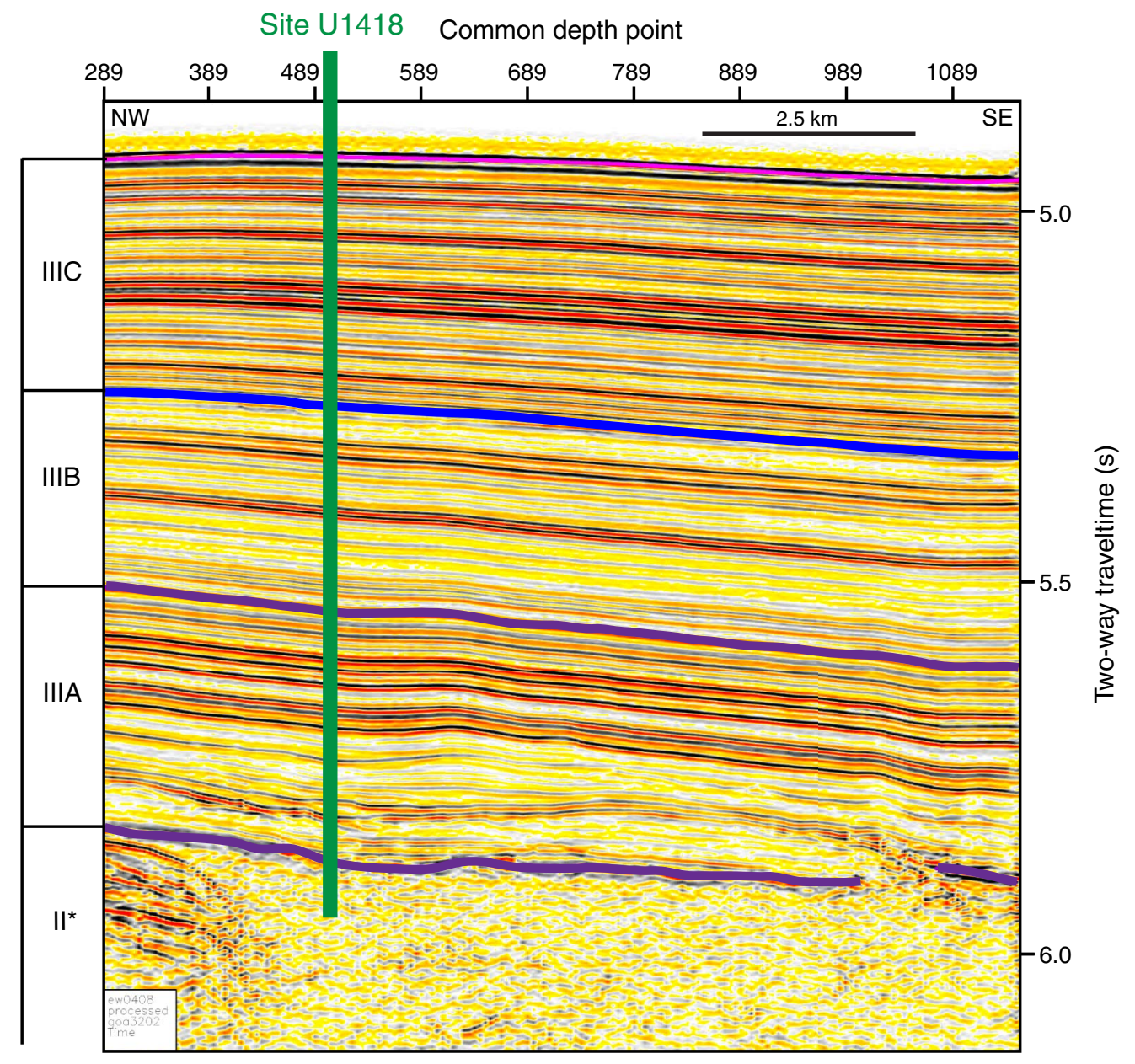


Figure F59. Regional seismic Profile STEEP07 ( 20 m vertical resolution at seafloor) acquired in 2008 aboard the R/V Marcus Langseth. Seismic Sequence III interpreted after Reece et al. (2011). Sequences IIIA, IIIB, IIIC, and II* defined as units here for correlation purposes.

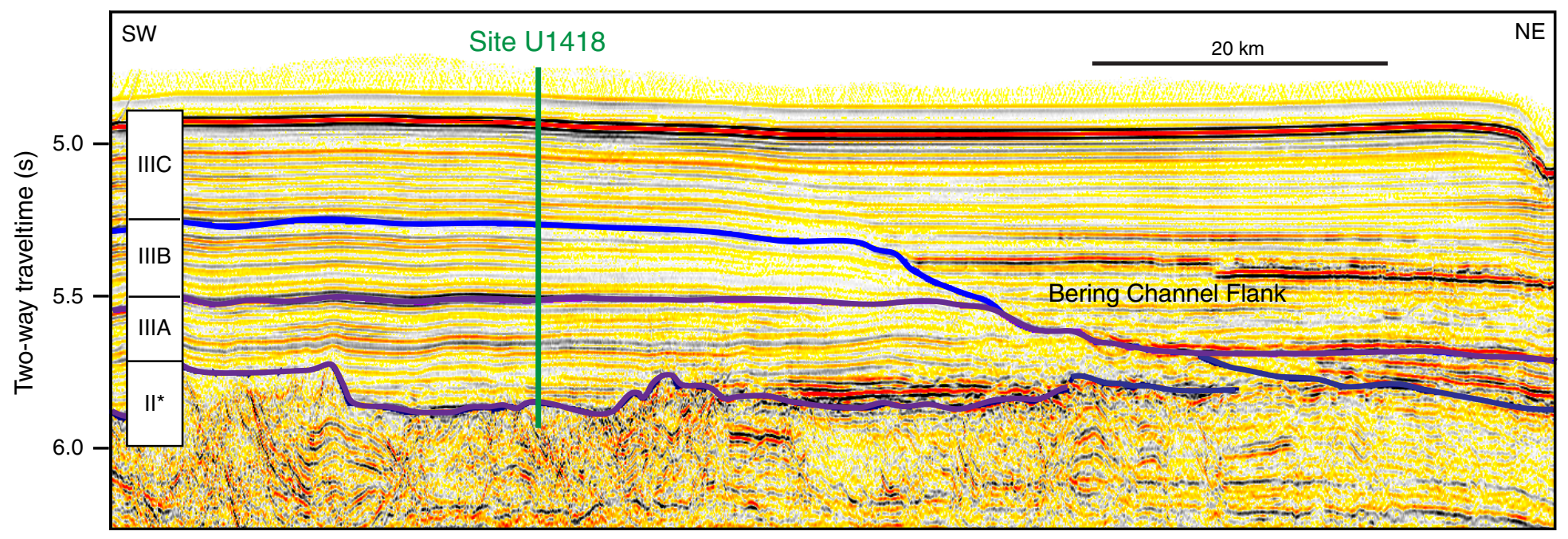


Figure F60. Sonic and density logs, discrete physical properties measurements, and seismic reflection Profile GOA3202. Seismic Sequences III and $\mathrm{II}^{*}$ are interpreted after Reece et al. (2011) and demarcated by colored horizons. Subsections of Sequence III are interpreted based on dominant seismic character. MAD = moisture and density, GRA = gamma ray attenuation, WRMSL $=$ Whole-Round Multisensor Logger, TWT $=$ two-way traveltime.

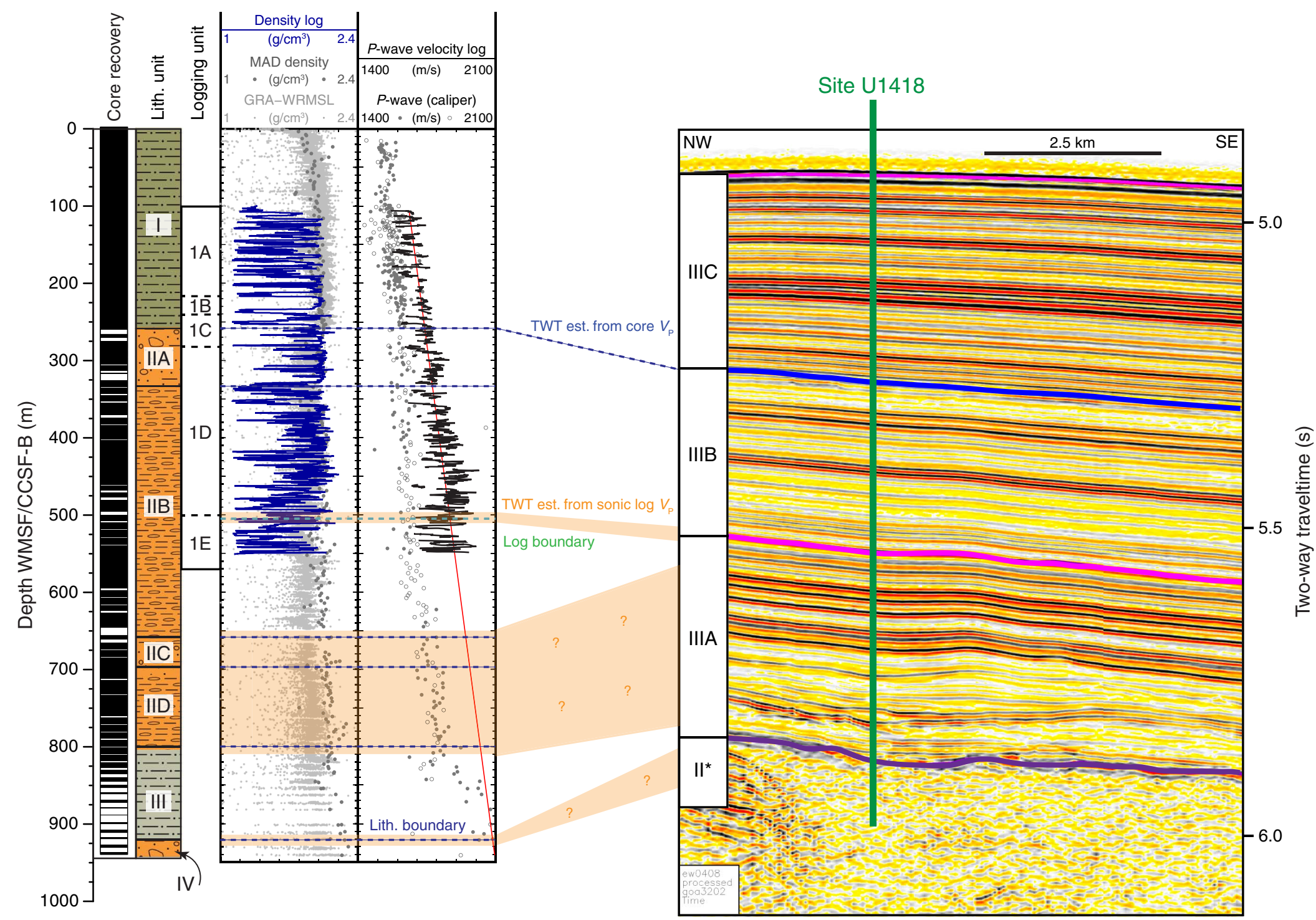


Table T1. Coring summary, Site U1418. (Continued on next four pages.)

Hole U1418A

Latitude: $58^{\circ} 46.6095^{\prime} \mathrm{N}$

Longitude: $144^{\circ} 29.5777^{\prime} \mathrm{W}$

Time on hole (h): 45.0

Seafloor (drill pipe measurement below rig floor, $\mathrm{m}$ DRF): 3679.2

Distance between rig floor and sea level $(\mathrm{m}): 11.0$

Water depth (drill pipe measurement from sea level, mbsl): 3668.2

Total penetration (drilling depth below seafloor, m DSF): 209.9

Total length of cored section (m): 209.9

Total core recovered $(\mathrm{m}): 216.85$

Core recovery (\%): 103.31

Total number of cores: 33

\section{Hole U1418B}

Latitude: $58^{\circ} 46.6100^{\prime} \mathrm{N}$

Longitude: $144^{\circ} 29.5559^{\prime} \mathrm{W}$

Time on hole (h): 3.5

Seafloor (drill pipe measurement below rig floor, $\mathrm{m}$ DRF): 3678.5

Distance between rig floor and sea level $(\mathrm{m}): 11.0$

Water depth (drill pipe measurement from sea level, mbsl): 3667.5

Total penetration (drilling depth below seafloor, m DSF): 17.0

Total length of cored section $(\mathrm{m}): 17.0$

Total core recovered $(\mathrm{m}): 17.08$

Core recovery (\%): 100.5

Total number of cores: 2

\section{Hole U1418C}

Latitude: $58^{\circ} 46.5991^{\prime} \mathrm{N}$

Longitude: $144^{\circ} 29.5570^{\prime} \mathrm{W}$

Time on hole (h): 39.75

Seafloor (drill pipe measurement below rig floor, $\mathrm{m}$ DRF): 3677.0

Distance between rig floor and sea level $(\mathrm{m}): 11.0$

Water depth (drill pipe measurement from sea level, mbsl): 3666.0

Total penetration (drilling depth below seafloor, $\mathrm{m} \mathrm{DSF}$ ): 230.7

Total length of cored section $(\mathrm{m}): 228.2$

Total core recovered $(\mathrm{m}): 229.48$

Core recovery (\%): 100.6

Total number of cores: 32

\section{Hole U1418D}

Latitude: $58^{\circ} 46.5993^{\prime} \mathrm{N}$

Longitude: $144^{\circ} 29.5579^{\prime} \mathrm{W}$

Time on hole (h): 49.75

Seafloor (drill pipe measurement below rig floor, $\mathrm{m} \mathrm{DRF):} 3677.5$

Distance between rig floor and sea level $(\mathrm{m}): 11.0$

Water depth (drill pipe measurement from sea level, mbsl): 3666.5

Total penetration (drilling depth below seafloor, $\mathrm{m} \mathrm{DSF}$ ): 305.8

Total length of cored section $(\mathrm{m}): 302.8$

Total core recovered $(\mathrm{m}): 279.77$

Core recovery (\%): 92.4

Total number of cores: 36

\section{Hole U1418E}

Latitude: $58^{\circ} 46.5890^{\prime} \mathrm{N}$

Longitude: $144^{\circ} 29.5771^{\prime} \mathrm{W}$

Time on hole $(\mathrm{h}): 34.0$

Seafloor (drill pipe measurement below rig floor, $\mathrm{m} \mathrm{DRF):} 3678.7$

Distance between rig floor and sea level $(\mathrm{m}): 11.0$

Water depth (drill pipe measurement from sea level, mbsl): 3667.7

Total penetration (drilling depth below seafloor, m DSF): 181.6

Total length of cored section $(\mathrm{m}): 100.6$

Total core recovered $(\mathrm{m}): 98.7$

Core recovery (\%): 98.1

Total number of cores: 11

\section{Hole U1418F}

Latitude: $58^{\circ} 46.5883^{\prime} \mathrm{N}$

Longitude: $144^{\circ} 29.5986^{\prime} \mathrm{W}$

Time on hole (h): 213.5

Seafloor (drill pipe measurement below rig floor, $\mathrm{m}$ DRF): 3678.0

Distance between rig floor and sea level $(\mathrm{m}): 11.0$

Water depth (drill pipe measurement from sea level, mbsl): 3667.0

Total penetration (drilling depth below seafloor, m DSF): 948.7

Total length of cored section $(\mathrm{m}): 688.7$ 
Table T1 (continued). (Continued on next page.)

Total core recovered $(\mathrm{m}): 495.2$

Core recovery (\%): 71.9

Total number of cores: 71

\begin{tabular}{|c|c|c|c|c|c|c|c|c|c|c|c|}
\hline \multirow[b]{2}{*}{ Core } & \multirow[b]{2}{*}{$\begin{array}{l}\text { Date } \\
\text { (2013) }\end{array}$} & \multirow[b]{2}{*}{$\begin{array}{l}\text { UTC time } \\
\text { (h) }\end{array}$} & \multicolumn{2}{|c|}{ Depth DSF $(m)$} & \multirow[b]{2}{*}{$\begin{array}{l}\text { Interval } \\
\text { advanced } \\
(\mathrm{m})\end{array}$} & \multicolumn{2}{|c|}{ Depth CSF $(m)$} & \multirow[b]{2}{*}{$\begin{array}{l}\text { Length } \\
\text { of core } \\
\text { recovered } \\
(\mathrm{m})\end{array}$} & \multirow[b]{2}{*}{$\begin{array}{c}\text { Recovery } \\
\text { (\%) }\end{array}$} & \multirow[b]{2}{*}{$\begin{array}{l}\text { Sections } \\
(N)\end{array}$} & \multirow[b]{2}{*}{$\begin{array}{c}\text { APC } \\
\text { system }\end{array}$} \\
\hline & & & $\begin{array}{c}\text { Top } \\
\text { of cored } \\
\text { interval }\end{array}$ & $\begin{array}{l}\text { Bottom } \\
\text { of cored } \\
\text { interval }\end{array}$ & & $\begin{array}{c}\text { Top } \\
\text { of cored } \\
\text { interval }\end{array}$ & $\begin{array}{l}\text { Bottom } \\
\text { of cored } \\
\text { interval }\end{array}$ & & & & \\
\hline \multicolumn{12}{|c|}{ 341-U1418A- } \\
\hline $1 \mathrm{H}$ & 24 Jun & 0835 & 0 & 4.8 & 4.8 & 0 & 4.87 & 4.87 & 101 & 5 & Full \\
\hline $2 \mathrm{H}$ & 24 Jun & 0940 & 4.8 & 14.3 & 9.5 & 4.8 & 13.96 & 9.16 & 96 & 7 & Full \\
\hline $3 \mathrm{H}$ & 24 Jun & 1035 & 14.3 & 23.8 & 9.5 & 14.3 & 23.97 & 9.67 & 102 & 8 & Full \\
\hline $4 \mathrm{H}$ & 24 Jun & 1150 & 23.8 & 33.3 & 9.5 & 23.8 & 33.58 & 9.78 & 103 & 8 & Full \\
\hline $5 \mathrm{H}$ & 24 Jun & 1245 & 33.3 & 42.8 & 9.5 & 33.3 & 42.96 & 9.66 & 102 & 8 & Full \\
\hline $6 \mathrm{H}$ & 24 Jun & 1340 & 42.8 & 52.3 & 9.5 & 42.8 & 52.73 & 9.93 & 105 & 8 & Full \\
\hline $7 \mathrm{H}$ & 24 Jun & 1450 & 52.3 & 61.8 & 9.5 & 52.3 & 62.19 & 9.89 & 104 & 8 & Full \\
\hline $8 \mathrm{H}$ & 24 Jun & 1540 & 61.8 & 71.3 & 9.5 & 61.8 & 71.35 & 9.55 & 101 & 7 & Full \\
\hline $9 \mathrm{H}$ & 24 Jun & 1635 & 71.3 & 80.8 & 9.5 & 71.3 & 81.00 & 9.70 & 102 & 8 & Full \\
\hline $10 \mathrm{H}$ & 24 Jun & 1750 & 80.8 & 90.3 & 9.5 & 80.8 & 89.97 & 9.17 & 97 & 9 & Full \\
\hline $11 \mathrm{H}$ & 24 Jun & 2020 & 90.3 & 99.8 & 9.5 & 90.3 & 100.12 & 9.82 & 103 & 8 & Full \\
\hline $12 \mathrm{H}$ & 24 Jun & 2130 & 99.8 & 109.3 & 9.5 & 99.8 & 109.74 & 9.94 & 105 & 8 & Full \\
\hline $13 \mathrm{H}$ & 24 Jun & 2255 & 109.3 & 118.4 & 9.1 & 109.3 & 118.40 & 9.10 & 100 & 8 & Full \\
\hline $14 \mathrm{H}$ & 25 Jun & 0115 & 118.4 & 123.1 & 4.7 & 118.4 & 123.41 & 5.01 & 107 & 5 & Half \\
\hline $15 \mathrm{H}$ & 25 Jun & 0210 & 123.1 & 127.8 & 4.7 & 123.1 & 128.17 & 5.07 & 108 & 5 & Half \\
\hline $16 \mathrm{H}$ & 25 Jun & 0300 & 127.8 & 132.5 & 4.7 & 127.8 & 132.75 & 4.95 & 105 & 5 & Half \\
\hline $17 \mathrm{H}$ & 25 Jun & 0340 & 132.5 & 137.2 & 4.7 & 132.5 & 137.58 & 5.08 & 108 & 5 & Half \\
\hline $18 \mathrm{H}$ & 25 Jun & 0425 & 137.2 & 141.9 & 4.7 & 137.2 & 141.88 & 4.68 & 100 & 4 & Half \\
\hline $19 \mathrm{H}$ & 25 Jun & 0510 & 141.9 & 146.6 & 4.7 & 141.9 & 147.06 & 5.16 & 110 & 5 & Half \\
\hline $20 \mathrm{H}$ & 25 Jun & 0555 & 146.6 & 151.3 & 4.7 & 146.6 & 151.52 & 4.92 & 105 & 5 & Half \\
\hline $21 \mathrm{H}$ & 25 Jun & 0645 & 151.3 & 156.0 & 4.7 & 151.3 & 156.36 & 5.06 & 108 & 5 & Half \\
\hline $22 \mathrm{H}$ & 25 Jun & 0730 & 156.0 & 160.7 & 4.7 & 156.0 & 161.06 & 5.06 & 108 & 5 & Half \\
\hline $23 \mathrm{H}$ & 25 Jun & 0815 & 160.7 & 165.4 & 4.7 & 160.7 & 165.68 & 4.98 & 106 & 5 & Half \\
\hline $24 \mathrm{H}$ & 25 Jun & 0900 & 165.4 & 170.1 & 4.7 & 165.4 & 170.50 & 5.10 & 109 & 5 & Half \\
\hline $25 \mathrm{H}$ & 25 Jun & 0955 & 170.1 & 174.8 & 4.7 & 170.1 & 175.09 & 4.99 & 106 & 5 & Half \\
\hline $26 \mathrm{H}$ & 25 Jun & 1045 & 174.8 & 179.5 & 4.7 & 174.8 & 179.75 & 4.95 & 105 & 5 & Half \\
\hline $27 \mathrm{H}$ & 25 Jun & 1155 & 179.5 & 184.2 & 4.7 & 179.5 & 184.49 & 4.99 & 106 & 5 & Half \\
\hline $28 \mathrm{H}$ & 25 Jun & 1250 & 184.2 & 188.9 & 4.7 & 184.2 & 189.23 & 5.03 & 107 & 5 & Half \\
\hline $29 \mathrm{H}$ & 25 Jun & 1340 & 188.9 & 193.6 & 4.7 & 188.9 & 193.72 & 4.87 & 104 & 5 & Half \\
\hline $30 \mathrm{H}$ & 25 Jun & 1445 & 193.6 & 198.3 & 4.7 & 193.6 & 198.44 & 4.84 & 103 & 5 & Half \\
\hline $31 \mathrm{H}$ & 25 Jun & 1540 & 198.3 & 203.0 & 4.7 & 198.3 & 203.24 & 4.94 & 105 & 5 & Half \\
\hline $32 \mathrm{H}$ & 25 Jun & 1630 & 203.0 & 206.1 & 3.1 & 203.0 & 206.10 & 3.10 & 100 & 3 & Half \\
\hline $33 \mathrm{H}$ & 25 Jun & 1725 & 206.1 & 209.9 & 3.8 & 206.1 & 209.93 & 3.83 & 101 & 4 & Half \\
\hline 341-U14 & & & & & & & & & & & \\
\hline $1 \mathrm{H}$ & 25 Jun & 2225 & 0 & 7.5 & 7.5 & 0 & 7.57 & 7.57 & 101 & 6 & Full \\
\hline $2 \mathrm{H}$ & 25 Jun & 2325 & 7.5 & 17.0 & 9.5 & 7.5 & 17.01 & 9.51 & 100 & 8 & Full \\
\hline 341-U14 & & & & & & & & & & & \\
\hline $1 \mathrm{H}$ & 26 Jun & 0450 & 0 & 8.6 & 8.6 & 0 & 8.67 & 8.67 & 101 & 7 & Full \\
\hline $2 \mathrm{H}$ & 26 Jun & 0605 & 8.6 & 18.1 & 9.5 & 8.6 & 17.99 & 9.39 & 99 & 8 & Full \\
\hline $3 \mathrm{H}$ & 26 Jun & 0700 & 18.1 & 27.6 & 9.5 & 18.1 & 27.24 & 9.14 & 96 & 8 & Full \\
\hline $4 \mathrm{H}$ & 26 Jun & 0750 & 27.6 & 37.1 & 9.5 & 27.6 & 37.28 & 9.68 & 102 & 8 & Full \\
\hline $5 \mathrm{H}$ & 26 Jun & 0855 & 37.1 & 46.6 & 9.5 & 37.1 & 46.95 & 9.85 & 104 & 8 & Full \\
\hline $6 \mathrm{H}$ & 26 Jun & 0950 & 46.6 & 56.1 & 9.5 & 46.6 & 56.36 & 9.76 & 103 & 8 & Full \\
\hline $7 \mathrm{H}$ & 26 Jun & 1045 & 56.1 & 65.6 & 9.5 & 56.1 & 64.14 & 8.04 & 85 & 7 & Full \\
\hline 81 & 26 Jun & & & & Drilled ir & terval from & 65.6 to 68 & $m \mathrm{mSF}^{\star \star \star}$ & & & \\
\hline $9 \mathrm{H}$ & 26 Jun & 1245 & 68.1 & 72.8 & 4.7 & 68.1 & 72.26 & 4.16 & 89 & 4 & Half \\
\hline $10 \mathrm{H}$ & 26 Jun & 1340 & 72.8 & 77.5 & 4.7 & 72.8 & 77.50 & 4.70 & 100 & 4 & Half \\
\hline $11 \mathrm{H}$ & 26 Jun & 1430 & 77.5 & 82.2 & 4.7 & 77.5 & 82.40 & 4.90 & 104 & 5 & Half \\
\hline $12 \mathrm{H}$ & 26 Jun & 1520 & 82.2 & 86.9 & 4.7 & 82.2 & 87.13 & 4.93 & 105 & 5 & Half \\
\hline $13 \mathrm{H}$ & 26 Jun & 1605 & 86.9 & 91.6 & 4.7 & 86.9 & 91.88 & 4.98 & 106 & 5 & Half \\
\hline $14 \mathrm{H}$ & 26 Jun & 1655 & 91.6 & 96.3 & 4.7 & 91.6 & 96.71 & 5.11 & 109 & 5 & Half \\
\hline $15 \mathrm{H}$ & 26 Jun & 1750 & 96.3 & 101.0 & 4.7 & 96.3 & 101.20 & 4.90 & 104 & 5 & Half \\
\hline $16 \mathrm{H}$ & 26 Jun & 1835 & 101.0 & 105.7 & 4.7 & 101.0 & 105.92 & 4.92 & 105 & 5 & Half \\
\hline $17 \mathrm{H}$ & 26 Jun & 1945 & 105.7 & 110.4 & 4.7 & 105.7 & 110.60 & 4.90 & 104 & 5 & Half \\
\hline $18 \mathrm{H}$ & 26 Jun & 2035 & 110.4 & 115.1 & 4.7 & 110.4 & 115.37 & 4.97 & 106 & 5 & Half \\
\hline $19 \mathrm{H}$ & 26 Jun & 2125 & 115.1 & 118.2 & 3.1 & 115.1 & 118.23 & 3.13 & 101 & 3 & Half \\
\hline $20 \mathrm{H}$ & 26 Jun & 2215 & 118.2 & 127.7 & 9.5 & 118.2 & 127.99 & 9.79 & 103 & 8 & Full \\
\hline $21 \mathrm{H}$ & 26 Jun & 2345 & 127.7 & 137.2 & 9.5 & 127.7 & 137.23 & 9.53 & 100 & 7 & Full \\
\hline $22 \mathrm{H}$ & 27 Jun & 0050 & 137.2 & 146.7 & 9.5 & 137.2 & 147.08 & 9.88 & 104 & 8 & Full \\
\hline $23 \mathrm{H}$ & 27 Jun & 0205 & 146.7 & 155.3 & 8.6 & 146.7 & 155.37 & 8.67 & 101 & 7 & Full \\
\hline $24 \mathrm{H}$ & 27 Jun & 0315 & 155.3 & 164.8 & 9.5 & 155.3 & 165.10 & 9.80 & 103 & 8 & Full \\
\hline
\end{tabular}


Table T1 (continued). (Continued on next page.)

\begin{tabular}{|c|c|c|c|c|c|c|c|c|c|c|c|}
\hline \multirow[b]{2}{*}{ Core } & \multirow[b]{2}{*}{$\begin{array}{l}\text { Date } \\
\text { (2013) }\end{array}$} & \multirow[b]{2}{*}{$\begin{array}{l}\text { UTC time } \\
\text { (h) }\end{array}$} & \multicolumn{2}{|c|}{ Depth DSF (m) } & \multirow[b]{2}{*}{$\begin{array}{l}\text { Interval } \\
\text { advanced } \\
(\mathrm{m})\end{array}$} & \multicolumn{2}{|c|}{ Depth CSF $(m)$} & \multirow{2}{*}{$\begin{array}{l}\text { Length } \\
\text { of core } \\
\text { recovered } \\
\quad(\mathrm{m})\end{array}$} & \multirow[b]{2}{*}{$\begin{array}{l}\text { Recovery } \\
\text { (\%) }\end{array}$} & \multirow[b]{2}{*}{$\begin{array}{l}\text { Sections } \\
(N)\end{array}$} & \multirow[b]{2}{*}{$\begin{array}{c}\text { APC } \\
\text { system }\end{array}$} \\
\hline & & & $\begin{array}{c}\text { Top } \\
\text { of cored } \\
\text { interval }\end{array}$ & $\begin{array}{l}\text { Bottom } \\
\text { of cored } \\
\text { interval }\end{array}$ & & $\begin{array}{c}\text { Top } \\
\text { of cored } \\
\text { interval }\end{array}$ & $\begin{array}{l}\text { Bottom } \\
\text { of cored } \\
\text { interval }\end{array}$ & & & & \\
\hline $25 \mathrm{H}$ & 27 Jun & 0415 & 164.8 & 174.0 & 9.2 & 164.8 & 174.09 & 9.29 & 101 & 8 & Full \\
\hline $26 \mathrm{H}$ & 27 Jun & 0520 & 174.0 & 183.5 & 9.5 & 174.0 & 183.57 & 9.57 & 101 & 8 & Full \\
\hline $27 \mathrm{H}$ & 27 Jun & 0625 & 183.5 & 191.9 & 8.4 & 183.5 & 191.93 & 8.43 & 100 & 7 & Full \\
\hline $28 \mathrm{H}$ & 27 Jun & 0740 & 191.9 & 201.4 & 9.5 & 191.9 & 201.45 & 9.55 & 101 & 8 & Full \\
\hline $29 \mathrm{H}$ & 27 Jun & 0845 & 201.4 & 209.7 & 8.3 & 201.4 & 209.69 & 8.29 & 100 & 6 & Full \\
\hline $30 \mathrm{H}$ & 27 Jun & 1000 & 209.7 & 218.2 & 8.5 & 209.7 & 218.16 & 8.46 & 100 & 6 & Full \\
\hline $31 \mathrm{H}$ & 27 Jun & 1105 & 218.2 & 225.0 & 6.8 & 218.2 & 224.53 & 6.33 & 93 & 5 & Full \\
\hline $32 \mathrm{H}$ & 27 Jun & 1210 & 225.0 & 230.7 & 5.7 & 225.0 & 230.76 & 5.76 & 101 & 6 & Full \\
\hline $33 \mathrm{H}$ & 27 Jun & 1330 & 230.7 & 230.7 & 0 & 230.7 & 230.70 & 0 & 0 & 0 & Full \\
\hline
\end{tabular}

341-U1418D-

1127 Jun

$2 \mathrm{H} \quad 27$ Jun

$3 \mathrm{H} \quad 27$ Jun $\quad 1720$

$\begin{array}{lll}3 \mathrm{H} & 27 \text { Jun } & 1810 \\ 4 \mathrm{H} & 27 \text { Jun } & 1905\end{array}$

$\begin{array}{lll}5 \mathrm{H} & 27 \text { Jun } & 2000 \\ 6 \mathrm{H} & 27 \text { Jun } & 2050\end{array}$

$\begin{array}{lll}7 \mathrm{H} & 27 \text { Jun } & 2135 \\ 8 \mathrm{H} & 27 \text { Jun } & 2300\end{array}$

$\begin{array}{lll}8 \mathrm{H} & 27 \text { Jun } & 2300 \\ 9 \mathrm{H} & 28 \text { Jun } & 0020\end{array}$

$\begin{array}{lll}10 \mathrm{H} & 28 \text { Jun } & 0120 \\ 11 \mathrm{H} & 28 \text { Jun } & 0215\end{array}$

$12 \mathrm{H} \quad 28$ Jun 0320

$\begin{array}{lll}13 \mathrm{H} & 28 \text { Jun } & 0425 \\ 14 \mathrm{H} & 28 \text { Jun } & 0520\end{array}$

$\begin{array}{ll}14 \mathrm{H} & 28 \text { Jun } \\ 15 \mathrm{H} & 28 \text { Jun }\end{array}$

$16 \mathrm{H} 28$ Jun

$17 \mathrm{H} \quad 28$ Jun 0805

$18 \mathrm{H} \quad 28$ Jun 0905

$\begin{array}{lll}18 \mathrm{H} & 28 \text { Jun } & 0905 \\ 19 \mathrm{H} & 28 \text { Jun } & 1025 \\ 20 \mathrm{H} & 28 \text { Jun } & 1120\end{array}$

$\begin{array}{lll}21 \mathrm{H} & 28 \text { Jun } & 1120 \\ 22 \mathrm{H} & 28 \text { Jun } & 1220 \\ 22 \mathrm{H} & 1410\end{array}$

$\begin{array}{lll}22 \mathrm{H} & 28 \text { Jun } & 1410 \\ 23 \mathrm{H} & 1510\end{array}$

$\begin{array}{lll}24 \mathrm{H} & 28 \text { Jun } & 1615 \\ 25 \mathrm{H} & 28 \text { Jun } & 1715\end{array}$

$26 \mathrm{H} \quad 28$ Jun 1830

$\begin{array}{lll}26 \mathrm{H} & 28 \text { Jun } & 1830 \\ 27 \mathrm{H} & 28 \text { Jun } & 1940\end{array}$

$\begin{array}{lll}28 \mathrm{H} & 28 \text { Jun } & 2100 \\ 29 \mathrm{H} & 28 \text { Jun } & 2200\end{array}$

$\begin{array}{lll}29 \mathrm{H} & 28 \text { Jun } & 2200 \\ 30 \mathrm{H} & 28 \text { Jun } & 2320 \\ 31 \mathrm{H} & 29 \text { Jun } & 0025\end{array}$

$\begin{array}{lll}32 \mathrm{H} & 29 \text { Jun } & 0135\end{array}$

$\begin{array}{lll}33 X & 29 \text { Jun } & 0535 \\ 34 X & 29 \text { Jun } & 0755\end{array}$

$35 X \quad 29$ Jun 1015

$36 X \quad 29$ Jun 1250

$37 X \quad 29$ Jun 1515

341-U1418E-

$11 \quad 30$ Jun

$2 \mathrm{H} \quad 30$ Jun

$31 \quad 30$ Jun

$4 \mathrm{H} \quad 30$ Jun

$5 \mathrm{H} \quad 30$ Jun

$6 \mathrm{H} \quad 30$ Jun

$\begin{array}{ll}7 \mathrm{H} & 30 \text { Jun } \\ 8 \mathrm{H} & 30 \text { Jun }\end{array}$

$9 \mathrm{H} \quad 30$ Jun $\quad 1205$

$10 \mathrm{H} \quad 30$ Jun 1350

$\begin{array}{lll}11 \mathrm{H} & 30 \text { Jun } & 1530 \\ 12 \mathrm{H} & 30 \text { Jun } & 1720\end{array}$

$13 \mathrm{H} \quad 30$ Jun 1820

0750

0845

0950

106.3
$1105-115.8$

$115.8-125.3$

$125.3 \quad 134.8$

$134.8 \quad 144.3$

$144.3 \quad 153.8$

$153.8 \quad 163.3$

$163.3 \quad 172.8$

172.8

181.6

341-U1418F-

$11 \quad 1$ Jul

$\begin{array}{ll}12 R & 1 \text { Jul } \\ 3 R & 2 \text { Jul } \\ 4 R & 2 \text { Jul }\end{array}$

2355

$260.0 \quad 269.7$

$269.7 \quad 279.4$

$279.4 \quad 289.1$

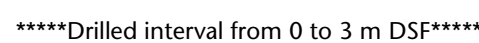

$\begin{array}{llll}9.5 & 3.0 & 12.44 & 9.44\end{array}$

$\begin{array}{llll}9.5 & 12.5 & 22.14 & 9.64\end{array}$

$\begin{array}{lll}9.5 & 22.0 & 31.09\end{array}$

$\begin{array}{lll}9.5 & 31.5 & 41.30\end{array}$

$\begin{array}{lll}9.5 & 41.0 & 50.70\end{array}$

$\begin{array}{lll}9.5 & 50.5 & 60.28\end{array}$

$7.9 \quad 60.0$

$9.5 \quad 67.9$

$9.5 \quad 77.4 \quad 85.69$

$\begin{array}{lll}9.5 & 77.4 & 85.69 \\ 9.5 & 86.9 & 96.71\end{array}$

$\begin{array}{lll}9.5 & 96.4 & 106.20\end{array}$

$\begin{array}{lrr}9.4 & 105.9 & 115.30\end{array}$

$\begin{array}{lll}7.5 & 115.3 & 123.81\end{array}$

$\begin{array}{lll}9.5 & 122.8 & 132.13\end{array}$

$\begin{array}{lll}9.5 & 132.3 & 141.92\end{array}$

$\begin{array}{lll}9.5 & 141.8 & 151.18\end{array}$

$\begin{array}{lll}9.5 & 151.3 & 161.06\end{array}$

$\begin{array}{lll}9.5 & 160.8 & 170.32\end{array}$

$\begin{array}{lll}9.5 & 170.3 & 180.51\end{array}$

$\begin{array}{lll}9.3 & 179.8 & 189.09\end{array}$

$\begin{array}{lll}7.3 & 189.1 & 196.43\end{array}$

$\begin{array}{lll}7.4 & 196.4 & 203.82\end{array}$

$\begin{array}{lll}8.0 & 203.8 & 211.89\end{array}$

$\begin{array}{lll}8.8 & 211.8 & 220.68\end{array}$

$\begin{array}{lll}9.4 & 220.6 & 230.03\end{array}$

$\begin{array}{lll}4.7 & 230.0 & 234.76\end{array}$

$\begin{array}{lll}4.7 & 234.7 & 239.46\end{array}$

$\begin{array}{lll}4.7 & 239.4 & 244.38\end{array}$

$\begin{array}{lll}4.5 & 244.1 & 248.63\end{array}$

$\begin{array}{lll}4.7 & 248.6 & 253.74\end{array}$

$\begin{array}{lll}4.0 & 253.3 & 257.36\end{array}$

$9.7 \quad 257.3 \quad 260.83$

$\begin{array}{lll}9.7 & 267.0 & 271.78\end{array}$

$\begin{array}{lll}9.7 & 276.7 & 284.14\end{array}$

$\begin{array}{lll}9.7 & 286.4 & 291.62 \\ 9.7 & 296.1 & 297.93\end{array}$

9.09

9.80

9.70

9.78

7.99
9.23

9.23

8.29
9.81

$\begin{array}{ll}9.81 & 103 \\ 9.80 & 103\end{array}$

$\begin{array}{ll}9.40 \quad 100 \\ 8.51 & 113\end{array}$

$8.51 \quad 113$

9.33

9.62

$9.38 \quad 99$

$\begin{array}{lr}9.76 & 103\end{array}$

9.52

10.21

9.29

7.33

7.42

8.09
8.88

8.88

9.43
4.76

4.76

4.76
4.98

4.53

5.14
4.06

4.06

3.53
4.78

7.44

5.22
1.83

$99 \quad 8 \quad$ Full

$101 \quad 8 \quad$ Full

103

102
103

103

$\begin{array}{lll}97 & 7 & \text { Full }\end{array}$

$87 \quad 7 \quad$ Full

Full

Full

Full

Full

Full

Full

Full

Full

Full

Full

Full

Full

Full

Full

Full

Half

Half

Half

Half

Half

Half

102

$36-4$

$\begin{array}{ll}39 & 4\end{array}$

77

54
19

Drilled interval from 0 to $78 \mathrm{~m} \mathrm{DSF}$ *****

$\begin{array}{lllllll}9.5 & 78 & 87.38 & 9.38 & 99 & 8 & \text { Full }\end{array}$

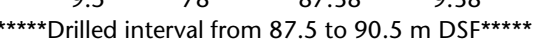

$\begin{array}{rrrrrrr}6.3 & 90.5 & 96.85 & 6.35 & 101 & 6 & \text { Full } \\ 9.5 & 96.8 & 106.47 & 9.67 & 102 & 8 & \text { Full } \\ 9.5 & 106.3 & 115.55 & 9.25 & 97 & 7 & \text { Full } \\ 9.5 & 115.8 & 125.53 & 9.73 & 102 & 8 & \text { Full } \\ 9.5 & 125.3 & 134.52 & 9.22 & 97 & 8 & \text { Full } \\ 9.5 & 134.8 & 144.32 & 9.52 & 100 & 8 & \text { Full } \\ 9.5 & 144.3 & 152.89 & 8.59 & 90 & 7 & \text { Full } \\ 9.5 & 153.8 & 162.94 & 9.14 & 96 & 8 & \text { Full } \\ 9.5 & 163.3 & 172.31 & 9.01 & 95 & 7 & \text { Full } \\ 8.8 & 172.8 & 181.64 & 8.84 & 100 & 7 & \text { Full }\end{array}$

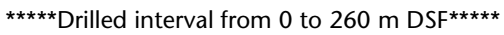

$\begin{array}{rrllrl}9.7 & 260.0 & 260.0 & 0 & 0 & 0 \\ 9.7 & 269.7 & 269.7 & 0 & 0 & 0 \\ 9.7 & 279.4 & 286.71 & 7.31 & 75 & 6\end{array}$


Table T1 (continued). (Continued on next page.)

\begin{tabular}{|c|c|c|c|c|c|c|c|c|c|c|c|}
\hline \multirow[b]{2}{*}{ Core } & \multirow[b]{2}{*}{$\begin{array}{l}\text { Date } \\
(2013)\end{array}$} & \multirow[b]{2}{*}{$\begin{array}{l}\text { UTC time } \\
\text { (h) }\end{array}$} & \multicolumn{2}{|c|}{ Depth DSF (m) } & \multirow[b]{2}{*}{$\begin{array}{l}\text { Interval } \\
\text { advanced } \\
(\mathrm{m})\end{array}$} & \multicolumn{2}{|c|}{ Depth CSF $(m)$} & \multirow{2}{*}{$\begin{array}{l}\text { Length } \\
\text { of core } \\
\text { recovered } \\
\text { (m) }\end{array}$} & \multirow[b]{2}{*}{$\begin{array}{l}\text { Recovery } \\
\text { (\%) }\end{array}$} & \multirow[b]{2}{*}{$\begin{array}{l}\text { Sections } \\
(N)\end{array}$} & \\
\hline & & & $\begin{array}{c}\text { Top } \\
\text { of cored } \\
\text { interval }\end{array}$ & $\begin{array}{l}\text { Bottom } \\
\text { of cored } \\
\text { interval }\end{array}$ & & $\begin{array}{c}\text { Top } \\
\text { of cored } \\
\text { interval }\end{array}$ & $\begin{array}{l}\text { Bottom } \\
\text { of cored } \\
\text { interval }\end{array}$ & & & & $\begin{array}{c}\text { APC } \\
\text { system }\end{array}$ \\
\hline $5 R$ & $2 \mathrm{Jul}$ & 0845 & 289.1 & 298.8 & 9.7 & 289.1 & 297.00 & 7.90 & 81 & 7 & \\
\hline $6 \mathrm{R}$ & $2 \mathrm{Jul}$ & 1045 & 298.8 & 308.5 & 9.7 & 298.8 & 306.79 & 7.99 & 82 & 7 & \\
\hline $7 \mathrm{R}$ & 2 Jul & 1230 & 308.5 & 318.2 & 9.7 & 308.5 & 315.26 & 6.76 & 70 & 6 & \\
\hline $8 \mathrm{R}$ & 2 Jul & 1415 & 318.2 & 327.9 & 9.7 & 318.2 & 318.98 & 0.78 & 8 & 2 & \\
\hline $9 \mathrm{R}$ & 2 Jul & 1645 & 327.9 & 337.6 & 9.7 & 327.9 & 336.56 & 8.66 & 89 & 7 & \\
\hline $10 \mathrm{R}$ & 2 Jul & 1830 & 337.6 & 347.3 & 9.7 & 337.6 & 345.19 & 7.59 & 78 & 6 & \\
\hline $11 \mathrm{R}$ & $2 \mathrm{Jul}$ & 2015 & 347.3 & 357.0 & 9.7 & 347.3 & 354.84 & 7.54 & 78 & 6 & \\
\hline $12 \mathrm{R}$ & $2 \mathrm{Jul}$ & 2215 & 357.0 & 366.7 & 9.7 & 357.0 & 366.59 & 9.59 & 99 & 8 & \\
\hline $13 R$ & $2 \mathrm{Jul}$ & 2355 & 366.7 & 376.4 & 9.7 & 366.7 & 372.32 & 5.62 & 58 & 5 & \\
\hline $14 R$ & 3 Jul & 0150 & 376.4 & 386.1 & 9.7 & 376.4 & 384.89 & 8.49 & 88 & 7 & \\
\hline $15 R$ & 3 Jul & 0420 & 386.1 & 395.8 & 9.7 & 386.1 & 395.10 & 9.00 & 93 & 7 & \\
\hline $16 \mathrm{R}$ & 3 Jul & 0555 & 395.8 & 405.5 & 9.7 & 395.8 & 404.50 & 8.70 & 90 & 7 & \\
\hline $17 \mathrm{R}$ & 3 Jul & 0740 & 405.5 & 415.2 & 9.7 & 405.5 & 414.67 & 9.17 & 95 & 7 & \\
\hline $18 \mathrm{R}$ & 3 Jul & 0920 & 415.2 & 424.9 & 9.7 & 415.2 & 424.15 & 8.95 & 92 & 7 & \\
\hline $19 \mathrm{R}$ & 3 Jul & 1105 & 424.9 & 434.6 & 9.7 & 424.9 & 434.79 & 9.89 & 102 & 8 & \\
\hline $20 \mathrm{R}$ & 3 Jul & 1240 & 434.6 & 444.3 & 9.7 & 434.6 & 444.09 & 9.49 & 98 & 8 & \\
\hline $21 \mathrm{R}$ & 3 Jul & 1425 & 444.3 & 454.0 & 9.7 & 444.3 & 454.03 & 9.73 & 100 & 8 & \\
\hline $22 \mathrm{R}$ & 3 Jul & 1600 & 454.0 & 463.7 & 9.7 & 454.0 & 462.73 & 8.73 & 90 & 7 & \\
\hline $23 R$ & 3 Jul & 1820 & 463.7 & 473.4 & 9.7 & 463.7 & 470.08 & 6.38 & 66 & 6 & \\
\hline $24 R$ & 3 Jul & 2015 & 473.4 & 483.1 & 9.7 & 473.4 & 479.30 & 5.90 & 61 & 5 & \\
\hline $25 \mathrm{R}$ & 3 Jul & 2210 & 483.1 & 492.8 & 9.7 & 483.1 & 492.79 & 9.69 & 100 & 8 & \\
\hline $26 \mathrm{R}$ & 4 Jul & 0000 & 492.8 & 502.5 & 9.7 & 492.8 & 497.38 & 4.58 & 47 & 4 & \\
\hline $27 \mathrm{R}$ & 4 Jul & 0145 & 502.5 & 512.2 & 9.7 & 502.5 & 509.86 & 7.36 & 76 & 6 & \\
\hline $28 \mathrm{R}$ & $4 \mathrm{Jul}$ & 0315 & 512.2 & 521.9 & 9.7 & 512.2 & 520.61 & 8.41 & 87 & 7 & \\
\hline $29 \mathrm{R}$ & 4 Jul & 0450 & 521.9 & 531.6 & 9.7 & 521.9 & 530.94 & 9.04 & 93 & 7 & \\
\hline $30 \mathrm{R}$ & 4 Jul & 0640 & 531.6 & 541.3 & 9.7 & 531.6 & 540.11 & 8.51 & 88 & 7 & \\
\hline $31 \mathrm{R}$ & $4 \mathrm{Jul}$ & 0820 & 541.3 & 551.0 & 9.7 & 541.3 & 550.73 & 9.43 & 97 & 8 & \\
\hline $32 \mathrm{R}$ & 4 Jul & 1005 & 551.0 & 560.7 & 9.7 & 551.0 & 560.89 & 9.89 & 102 & 8 & \\
\hline $33 R$ & $4 \mathrm{Jul}$ & 1135 & 560.7 & 570.4 & 9.7 & 560.7 & 570.61 & 9.91 & 102 & 8 & \\
\hline $34 R$ & 4 Jul & 1320 & 570.4 & 580.1 & 9.7 & 570.4 & 580.07 & 9.67 & 100 & 8 & \\
\hline $35 \mathrm{R}$ & 4 Jul & 1450 & 580.1 & 589.8 & 9.7 & 580.1 & 589.98 & 9.88 & 102 & 8 & \\
\hline $36 \mathrm{R}$ & 4 Jul & 1625 & 589.8 & 599.5 & 9.7 & 589.8 & 596.99 & 7.19 & 74 & 6 & \\
\hline $37 R$ & 4 Jul & 1800 & 599.5 & 609.2 & 9.7 & 599.5 & 608.01 & 8.51 & 88 & 7 & \\
\hline $38 \mathrm{R}$ & 4 Jul & 1945 & 609.2 & 618.9 & 9.7 & 609.2 & 617.71 & 8.51 & 88 & 7 & \\
\hline $39 R$ & 4 Jul & 2135 & 618.9 & 628.6 & 9.7 & 618.9 & 625.90 & 7.00 & 72 & 6 & \\
\hline $40 \mathrm{R}$ & $4 \mathrm{Jul}$ & 2320 & 628.6 & 638.3 & 9.7 & 628.6 & 638.34 & 9.74 & 100 & 8 & \\
\hline $41 R$ & $5 \mathrm{Jul}$ & 0105 & 638.3 & 648.0 & 9.7 & 638.3 & 647.90 & 9.60 & 99 & 8 & \\
\hline $42 \mathrm{R}$ & 5 Jul & 0245 & 648.0 & 657.7 & 9.7 & 648.0 & 648.00 & 0 & 0 & 0 & \\
\hline $43 R$ & $5 \mathrm{Jul}$ & 0505 & 657.7 & 667.4 & 9.7 & 657.7 & 662.93 & 5.23 & 54 & 5 & \\
\hline $44 \mathrm{R}$ & 5 Jul & 0730 & 667.4 & 677.1 & 9.7 & 667.4 & 675.69 & 8.29 & 85 & 7 & \\
\hline $45 \mathrm{R}$ & 5 Jul & 0920 & 677.1 & 686.8 & 9.7 & 677.1 & 685.75 & 8.65 & 89 & 7 & \\
\hline $46 \mathrm{R}$ & 5 Jul & 1110 & 686.8 & 696.5 & 9.7 & 686.8 & 696.34 & 9.54 & 98 & 8 & \\
\hline $47 R$ & $5 \mathrm{Jul}$ & 1300 & 696.5 & 706.2 & 9.7 & 696.5 & 706.40 & 9.90 & 102 & 8 & \\
\hline $48 \mathrm{R}$ & 5 Jul & 1500 & 706.2 & 715.9 & 9.7 & 706.2 & 713.90 & 7.70 & 79 & 7 & \\
\hline $49 R$ & 5 Jul & 1655 & 715.9 & 725.6 & 9.7 & 715.9 & 725.13 & 9.23 & 95 & 8 & \\
\hline $50 R$ & $5 \mathrm{Jul}$ & 1850 & 725.6 & 735.3 & 9.7 & 725.6 & 734.13 & 8.53 & 88 & 7 & \\
\hline $51 \mathrm{R}$ & 5 Jul & 2035 & 735.3 & 745.0 & 9.7 & 735.3 & 744.37 & 9.07 & 94 & 8 & \\
\hline $52 \mathrm{R}$ & 5 Jul & 2230 & 745.0 & 754.7 & 9.7 & 745.0 & 754.50 & 9.50 & 98 & 8 & \\
\hline $53 R$ & $6 \mathrm{Jul}$ & 0015 & 754.7 & 764.4 & 9.7 & 754.7 & 762.08 & 7.38 & 76 & 6 & \\
\hline $54 \mathrm{R}$ & $6 \mathrm{Jul}$ & 0215 & 764.4 & 774.1 & 9.7 & 764.4 & 772.84 & 8.44 & 87 & 7 & \\
\hline $55 \mathrm{R}$ & $6 \mathrm{Jul}$ & 0420 & 774.1 & 783.8 & 9.7 & 774.1 & 782.64 & 8.54 & 88 & 7 & \\
\hline $56 \mathrm{R}$ & $6 \mathrm{Jul}$ & 0620 & 783.8 & 793.5 & 9.7 & 783.8 & 791.33 & 7.53 & 78 & 7 & \\
\hline $57 \mathrm{R}$ & $6 \mathrm{Jul}$ & 0815 & 793.5 & 803.2 & 9.7 & 793.5 & 802.14 & 8.64 & 89 & 7 & \\
\hline $58 \mathrm{R}$ & $6 \mathrm{Jul}$ & 1005 & 803.2 & 812.9 & 9.7 & 803.2 & 811.78 & 8.58 & 88 & 7 & \\
\hline $59 \mathrm{R}$ & $6 \mathrm{Jul}$ & 1200 & 812.9 & 822.6 & 9.7 & 812.9 & 820.71 & 7.81 & 81 & 6 & \\
\hline $60 \mathrm{R}$ & $6 \mathrm{Jul}$ & 1400 & 822.6 & 832.3 & 9.7 & 822.6 & 829.51 & 6.91 & 71 & 6 & \\
\hline $61 \mathrm{R}$ & $6 \mathrm{Jul}$ & 1605 & 832.3 & 842.0 & 9.7 & 832.3 & 837.45 & 5.15 & 53 & 5 & \\
\hline $62 \mathrm{R}$ & $6 \mathrm{Jul}$ & 1755 & 842.0 & 851.7 & 9.7 & 842.0 & 847.38 & 5.38 & 55 & 5 & \\
\hline $63 R$ & $6 \mathrm{Jul}$ & 1945 & 851.7 & 861.4 & 9.7 & 851.7 & 855.32 & 3.62 & 37 & 4 & \\
\hline $64 \mathrm{R}$ & $6 \mathrm{Jul}$ & 2140 & 861.4 & 871.1 & 9.7 & 861.4 & 863.58 & 2.18 & 22 & 3 & \\
\hline $65 \mathrm{R}$ & $6 \mathrm{Jul}$ & 2335 & 871.1 & 880.8 & 9.7 & 871.1 & 874.34 & 3.24 & 33 & 4 & \\
\hline $66 \mathrm{R}$ & $7 \mathrm{Jul}$ & 0120 & 880.8 & 890.5 & 9.7 & 880.8 & 881.97 & 1.17 & 12 & 2 & \\
\hline $67 R$ & 7 Jul & 0325 & 890.5 & 900.2 & 9.7 & 890.5 & 890.71 & 0.21 & 2 & 1 & \\
\hline $68 \mathrm{R}$ & 7 Jul & 0525 & 900.2 & 909.9 & 9.7 & 900.2 & 902.16 & 1.96 & 20 & 3 & \\
\hline $69 R$ & 7 Jul & 0740 & 909.9 & 919.6 & 9.7 & 909.9 & 913.53 & 3.63 & 37 & 4 & \\
\hline $70 R$ & 7 Jul & 1015 & 919.6 & 929.3 & 9.7 & 919.6 & 921.77 & 2.17 & 22 & 3 & \\
\hline $71 \mathrm{R}$ & 7 Jul & 1245 & 929.3 & 939.0 & 9.7 & 929.3 & 932.79 & 3.49 & 36 & 4 & \\
\hline
\end{tabular}


Table T1 (continued).

\begin{tabular}{|c|c|c|c|c|c|c|c|c|c|c|c|}
\hline \multirow[b]{2}{*}{ Core } & \multirow[b]{2}{*}{$\begin{array}{l}\text { Date } \\
\text { (2013) }\end{array}$} & \multirow[b]{2}{*}{$\begin{array}{l}\text { UTC time } \\
\text { (h) }\end{array}$} & \multicolumn{2}{|c|}{ Depth DSF (m) } & \multirow[b]{2}{*}{$\begin{array}{l}\text { Interval } \\
\text { advanced } \\
\text { (m) }\end{array}$} & \multicolumn{2}{|c|}{ Depth CSF (m) } & \multirow{2}{*}{$\begin{array}{l}\text { Length } \\
\text { of core } \\
\text { recovered } \\
\text { (m) }\end{array}$} & \multirow[b]{2}{*}{$\begin{array}{c}\text { Recovery } \\
\text { (\%) }\end{array}$} & \multirow[b]{2}{*}{$\begin{array}{l}\text { Sections } \\
(N)\end{array}$} & \multirow[b]{2}{*}{$\begin{array}{c}\text { APC } \\
\text { system }\end{array}$} \\
\hline & & & $\begin{array}{c}\text { Top } \\
\text { of cored } \\
\text { interval }\end{array}$ & $\begin{array}{l}\text { Bottom } \\
\text { of cored } \\
\text { interval }\end{array}$ & & $\begin{array}{c}\text { Top } \\
\text { of cored } \\
\text { interval }\end{array}$ & $\begin{array}{l}\text { Bottom } \\
\text { of cored } \\
\text { interval }\end{array}$ & & & & \\
\hline $72 \mathrm{R}$ & $7 \mathrm{Jul}$ & 1530 & 939.0 & 948.7 & 9.7 & 939.0 & 941.44 & 2.44 & 25 & 3 & \\
\hline
\end{tabular}

DSF $=$ drilling depth below seafloor, $C S F=$ core depth below seafloor. Core: $1=$ drilled interval, $\mathrm{H}=$ advanced piston corer $(\mathrm{APC})$ core, $\mathrm{X}=$ extended core barrel core, $\mathrm{R}=$ rotary core barrel core. 
Table T2. Summary of observed lithofacies, Site U1418. (Continued on next two pages.)

\begin{tabular}{|c|c|c|c|c|c|c|}
\hline Main facies & Subfacies & Facies & Description & Marine microfossils & Lithostratigraphic unit & $\begin{array}{l}\text { Tentative depositional } \\
\text { environment/diagenesis }\end{array}$ \\
\hline \multirow[t]{3}{*}{ Mud } & $\begin{array}{l}\text { Massive mud with } \\
\text { lonestones }\end{array}$ & F1a & $\begin{array}{l}\text { (Dark) gray to (dark) greenish gray; } \\
\text { Facies thickness from } 2.5 \mathrm{~cm} \text { to } 9.64 \mathrm{~m} \\
\text { Varying amounts of lonestones from dispersed to abundant; } \\
\text { Mostly none to slight bioturbation, occasionally moderate to heavy bioturbation; } \\
\text { Occasional color banding and lamination; } \\
\text { Occasional occurrence of black mottles and silt/sand patches (<1 cm diameter); } \\
\text { Interbedded with Facies F1c, F1d, F2a, F2b, F3a, F4a, F4d, F5a, F5b, F5c, F6, and } \\
\quad \text { F7 }\end{array}$ & Rare diatoms & $\begin{array}{l}\text { I, IA, IIA, IIB, IIC, IID, } \\
\text { III }\end{array}$ & $\begin{array}{l}\text { Suspension fall-out, ice rafting, } \\
\text { or sediment gravity flows }\end{array}$ \\
\hline & $\begin{array}{l}\text { Massive mud } \\
\text { without lonestones }\end{array}$ & $\mathrm{F} 1 \mathrm{~b}$ & $\begin{array}{l}\text { (Dark) gray to (dark) greenish gray; } \\
\text { Facies thickness from } 2 \mathrm{~cm} \text { to } 5.72 \mathrm{~m} \\
\text { Mostly massive, occasional silt laminae; } \\
\text { Occasional color banding; } \\
\text { Rarely inclined; } \\
\text { Absent lonestones; } \\
\text { Mostly none to slight bioturbation, rarely moderate to heavy bioturbation; } \\
\text { Occasional occurrence of black mottles and silt/sand patches (<1 cm diameter); } \\
\text { Interbedded with Facies F1 a, F1d, F2a, F2b, F3a, F4a, F4d, F5a, F5b, F5c, F6, F7, } \\
\text { and F8 }\end{array}$ & Rare diatoms & $\begin{array}{l}\text { I, IA, IIA, IIB, IIC, IID, } \\
\text { III }\end{array}$ & $\begin{array}{l}\text { Suspension fall-out or sediment } \\
\text { gravity flows }\end{array}$ \\
\hline & $\begin{array}{l}\text { Laminated/Bedded } \\
\text { mud }\end{array}$ & $\mathrm{F} 1 \mathrm{C}$ & $\begin{array}{l}\text { (Dark) gray to (dark) greenish gray; } \\
\text { Facies thickness from } 5 \mathrm{~mm} \text { to } 4.85 \mathrm{~m} \text {; } \\
\text { Mostly none to slight bioturbation; } \\
\text { Lamination resulting from slight color variations, presumably related to minor } \\
\text { changes in grain size and/or geochemical variations } \\
\text { Lamination mostly from submillimeter to } 0.5 \mathrm{~cm} \text {, occasional very thin bedding } \\
\text { (<2.5 cm) possible; } \\
\text { Mostly gradational contacts, very rarely sharp; } \\
\text { Rare lonestones; } \\
\text { Interbedded with Facies F1a, F1c, F2a, F2b, F3a, F5c, and F8 }\end{array}$ & Not documented & IIB, IIC, IID, III & $\begin{array}{l}\text { Suspension fall-out, ice rafting, } \\
\text { or sediment gravity flows }\end{array}$ \\
\hline \multirow[t]{2}{*}{ Silt } & Silt & $\mathrm{F} 2 \mathrm{a}$ & $\begin{array}{l}\text { Gray to very dark gray; } \\
\text { Facies thickness from } 2 \mathrm{~mm} \text { to } 7 \mathrm{~cm} ; \\
\text { Sharp to gradational upper and lower contacts; } \\
\text { Often normally graded; } \\
\text { Occasionally volcaniclastic bearing; } \\
\text { Separated from interbedded silt with mud because of relatively large bed } \\
\text { thickness and interbedding with other facies than mud; } \\
\text { Interbedded with Facies } F 1 \text { a, F1c, F1d, F2b, F3a, F5a, F5b, and F7 }\end{array}$ & Not documented & I, IIA, IID, III & Sediment gravity flows \\
\hline & $\begin{array}{l}\text { Interbedded/ } \\
\text { Interlaminated silt } \\
\text { and mud }\end{array}$ & $\mathrm{F} 2 \mathrm{~b}$ & $\begin{array}{l}\text { Dark gray to very dark gray; } \\
\text { Facies thickness from } 3 \mathrm{~cm} \text { to } 10.67 \mathrm{~m} \text {; } \\
\text { Silt laminae interbedded in mud; } \\
\text { Most laminae }<5 \mathrm{~mm} \text { thick, up to } 50 \text { laminae per section; } \\
\text { Spacing from } 2 \mathrm{~mm} \text { to } 17 \mathrm{~cm} \text {; } \\
\text { Occasional color banding, dispersed lonestones are present; } \\
\text { None to slight bioturbation; } \\
\text { Most silt laminae with same color as matrix but sometimes lighter; } \\
\text { Mostly sharp lower contacts of the silt laminae, sharp to gradational upper } \\
\text { contacts; } \\
\text { Occasionally calcareous, diatom, and volcaniclastic bearing; } \\
\text { Interbedded with Facies F1a, F1c, F1d, F2a, F3a, F4a, F5a, F5b, F6, F7, and F8 }\end{array}$ & Diatoms & I, III & $\begin{array}{l}\text { Mud: suspension fall-out from } \\
\text { surface water plumes and } \\
\text { sediment gravity flows } \\
\text { Silt: sediment gravity flows }\end{array}$ \\
\hline
\end{tabular}


Table T2 (continued). (Continued on next page.)

\begin{tabular}{|c|c|c|c|c|c|c|}
\hline Main facies & Subfacies & Facies & Description & Marine microfossils & Lithostratigraphic unit & $\begin{array}{l}\text { Tentative depositional } \\
\text { environment/diagenesis }\end{array}$ \\
\hline Sand & $\begin{array}{l}\text { Very fine to coarse } \\
\text { sand }\end{array}$ & F3a & $\begin{array}{l}\text { Gray to very dark gray; } \\
\text { Mostly medium to (very) fine sand, occasionally muddy; } \\
\text { Very rarely coarse sand; } \\
\text { Mostly } 1 \text { to } 11 \mathrm{~cm} \text { thick, one } 38 \mathrm{~cm} \text { interval heavily disturbed (irregular } \\
\text { occurrence of sand patches in mud); } \\
\text { Mostly normally graded; } \\
\text { Mostly erosive lower contacts; } \\
\text { Sharp and gradational upper contacts; } \\
\text { Often poorly sorted; } \\
\text { Occasionally with diatoms and volcanic ash; } \\
\text { Composition includes quartz, hornblende, and opaque grains; } \\
\text { Interbedded with Facies F1a, F1c, F1d, F2a,F2b, F5a, F5b, and F7 }\end{array}$ & $\begin{array}{l}\text { Occasionally with } \\
\text { diatoms }\end{array}$ & 1 & Sediment gravity flows \\
\hline \multirow[t]{2}{*}{ Diamict } & Muddy diamict & $\mathrm{F} 4 \mathrm{a}$ & $\begin{array}{l}\text { Dark gray, very dark gray, and very dark greenish gray; } \\
\text { Muddy matrix, mostly clast poor, clasts up to pebble size; } \\
\text { Facies thickness from } 2 \mathrm{~cm} \text { to } 14.35 \mathrm{~m} \text {; } \\
\text { Mostly massive but occasionally some centimeter-thick intervals with ( }<5 \mathrm{~mm}) \\
\text { thick laminae; } \\
\text { Lower contacts either sharp or characterized by gradual increase in clast } \\
\text { numbers; } \\
\text { Upper boundary either gradational or sharp due to drop in amounts of clasts; } \\
\text { Variations between intervals with higher and lower clast content within the facies } \\
\text { may occur; } \\
\text { Mostly not bioturbated, but intervals in lower parts of Hole U1418F are } \\
\text { moderately bioturbated; } \\
\text { Some color banding may occur; } \\
\text { May very rarely contain volcaniclastic ash; } \\
\text { Clast types include quartz, feldspar, and biotite, as well as granitoid rocks, meta- } \\
\text { sediment, black, red and white chert (partly with quartz veins), rhyolite, (black) } \\
\text { siltstone, granodiorite to gabbro and basalt, and rip-up clasts of mud; } \\
\text { Interbedded with Facies F1a, F1c, F2b, and F7 }\end{array}$ & Not documented & IIA, IIB, IIC, IID, III & $\begin{array}{l}\text { Suspension settling and ice } \\
\text { rafting (icebergs and/or sea } \\
\text { ice) }\end{array}$ \\
\hline & $\begin{array}{l}\text { Interbedded mud } \\
\text { and diamict }\end{array}$ & $\mathrm{F} 4 \mathrm{~d}$ & $\begin{array}{l}\text { Dark gray to very dark gray; } \\
\text { Facies thickness from } 12 \mathrm{~cm} \text { to } 4.41 \mathrm{~m} \\
\text { Lamination (in muddy intervals) and color banding to lighter gray possible; } \\
\text { None to slight bioturbation; } \\
\text { Diamicts mostly } \sim 5 \mathrm{~mm} \text { to } \sim 4 \mathrm{~cm} \text { thick, contain matrix of mud to very fine sand } \\
\text { and mostly clasts of coarse sand to granules, rare clasts up to } 2 \mathrm{~cm} \text {, often } \\
\text { associated with darker parts of color banding; } \\
\text { Gradational contacts between muddy and diamict intervals; } \\
\text { Interbedded with Facies F1a, F1c, F5b, and F7 }\end{array}$ & Not documented & IIA, IIB & $\begin{array}{l}\text { Suspension settling and ice } \\
\text { rafting (icebergs and/or sea } \\
\text { ice) }\end{array}$ \\
\hline Diatom ooze & & F5a & $\begin{array}{l}\text { Dark greenish gray or very dark grayish brown; } \\
\text { Facies thickness from } 3 \mathrm{~cm} \text { to } 2.91 \mathrm{~m} ; \\
\text { Sharp to gradational upper and lower contacts; } \\
\text { Occasionally with volcanic ash; } \\
\text { Mostly moderate to heavy bioturbation; } \\
\text { Lonestones are occasionally present and black mottles occur frequently; } \\
\text { Interbedded with Facies F1a, F1c, F2a, F2b, F3a, F5b, and F7 }\end{array}$ & $\begin{array}{l}\text { Diatoms and other } \\
\text { biosiliceous } \\
\text { material (e.g., } \\
\text { sponge spicules) }\end{array}$ & I, IIB, IIC & $\begin{array}{l}\text { High-productivity environment } \\
\text { and/or low terrigenous input } \\
\text { and/or better preservation }\end{array}$ \\
\hline $\begin{array}{l}\text { Biosiliceous ooze; } \\
\text { biosiliceous-rich/ } \\
\text { bearing mud and } \\
\text { sand; mud with } \\
\text { diatoms/biosilica }\end{array}$ & & $\mathrm{F} 5 \mathrm{~b}$ & $\begin{array}{l}\text { Dark greenish gray; } \\
\text { Ooze or rich/bearing with diatoms, sponge spicules, foraminifers, nannofossils; } \\
\text { Facies thickness from } 23 \text { to } 53 \mathrm{~cm} \text { (ooze), } 51 \mathrm{~cm} \text { to } 1.5 \mathrm{~m} \text { (diatom rich), } 40 \mathrm{~cm} \text { to } \\
\quad 4.5 \mathrm{~m} \text { (diatom bearing), } 20.5 \mathrm{~cm} \text { to } 2.62 \mathrm{~m} \text { (mud with biosilica) } \\
\text { Slight to heavy bioturbation; } \\
\text { Few lonestones; } \\
\text { Often with volcanic ash; } \\
\text { Interbedded with Facies F1a, F1c, F2a, F2b, F3a, F4d, F5a, F5c, F7, and F8 }\end{array}$ & $\begin{array}{l}\text { Diatoms, sponge } \\
\text { spicules, } \\
\text { foraminifers, } \\
\text { nannofossils }\end{array}$ & I, IIA, IIB, IIC & $\begin{array}{l}\text { Temporarily increased } \\
\text { productivity and/or reduced } \\
\text { suspension settling and/or } \\
\text { better preservation }\end{array}$ \\
\hline
\end{tabular}


Table T2 (continued).

\begin{tabular}{|c|c|c|c|c|c|c|}
\hline Main facies & Subfacies & Facies & Description & Marine microfossils & Lithostratigraphic unit & $\begin{array}{l}\text { Tentative depositional } \\
\text { environment/diagenesis }\end{array}$ \\
\hline $\begin{array}{l}\text { Calcareous/ } \\
\text { carbonate-bearing/ } \\
\text { rich mud }\end{array}$ & & $\mathrm{F} 5 \mathrm{c}$ & $\begin{array}{l}\text { Gray, dark gray, very dark gray, dark greenish gray, and very dark greenish gray; } \\
\text { Facies thickness from } 1 \mathrm{~mm} \text { to } 1.96 \mathrm{~m} \text {; } \\
\text { Mostly slight to moderate but occasionally absent bioturbation; } \\
\text { Lonestones occasionally present; } \\
\text { Scattered foraminifer tests; } \\
\text { Occasionally in intervals with parallel lamination, tilted beds, or volcanic ash; } \\
\text { Gradational contacts; } \\
\text { Interbedded with Facies F1a, F1c, F1d, F5b, F7, and F8 }\end{array}$ & $\begin{array}{l}\text { Foraminifers; } \\
\text { occasionally } \\
\text { diatoms }\end{array}$ & I, IIB, III, IID & $\begin{array}{l}\text { Temporarily increased } \\
\text { productivity and/or reduced } \\
\text { suspension settling and/or } \\
\text { better preservation }\end{array}$ \\
\hline Ash & Volcanic ash & F6 & $\begin{array}{l}\text { Usually gray to brown; } \\
\text { Facies thickness from } 1 \text { to } 5 \mathrm{~cm} \text {; } \\
\text { Sharp lower contacts; } \\
\text { Sharp to gradational upper contacts; } \\
\text { Primarily vitric shards (glass); } \\
\text { Some intervals affected by moderate to heavy bioturbation, consequently, } \\
\text { distinct ash layers are occasionally no longer visible, but the material is included } \\
\text { in burrow fill; } \\
\text { Often interbedded with Facies F1a, F1c, F2b, and F7 }\end{array}$ & Not documented & I, III & $\begin{array}{l}\text { Suspension settling after } \\
\text { subaerial eruptions }\end{array}$ \\
\hline $\begin{array}{l}\text { Volcaniclastic mud, } \\
\text { sand, diamict, and/ } \\
\text { or ooze }\end{array}$ & & F7 & $\begin{array}{l}\text { Gray, dark gray, very dark gray, and dark greenish gray; } \\
\text { Volcaniclastic-rich/bearing or trace amounts of volcanic ash; } \\
\text { Facies thickness from } 5 \mathrm{~mm} \text { to } 5.58 \mathrm{~m} \text {; } \\
\text { Mostly slight to moderate but occasionally absent bioturbation; } \\
\text { Lonestones present; } \\
\text { Occurrence in massive, color-banded, and laminated intervals; } \\
\text { Often in association with mud with higher amounts of biosiliceous and } \\
\text { calcareous components; } \\
\text { Gradational and sharp contacts; } \\
\text { Interbedded with Facies F1a, F1c, F2a, F2b, F3a, F4a, F4d, F5a, F5b, F5c, and F6 }\end{array}$ & $\begin{array}{l}\text { Biosiliceous and } \\
\text { calcareous } \\
\text { microfossils }\end{array}$ & I, IIA, IIB, IIC, III & $\begin{array}{l}\text { Volcanic detritus either } \\
\text { bioturbated or reworked/ } \\
\text { redeposited by sediment } \\
\text { gravity flows }\end{array}$ \\
\hline Rock & & F8 & $\begin{array}{l}\text { Light to very dark gray siltstone and sandstone, most often with calcite cement; } \\
\text { Thickness from } 1 \text { to } 6 \mathrm{~cm} \text {, generally covering the entire core width, partly "flame } \\
\text { structures" intruding into surrounding mud } \\
\text { Often interbedded with Facies F1c, F1d, F2b, F5b, and F5c }\end{array}$ & Not documented & III & In situ carbonate cementation \\
\hline $\begin{array}{l}\text { Intrastratal contorted } \\
\text { mud and diamict }\end{array}$ & & F9 & $\begin{array}{l}\text { Very dark greenish gray mud mixed with very dark greenish gray clast-rich } \\
\text { muddy diamict; } \\
\text { Facies thickness is } 7.79 \text { m (limited to Cores } 341-\mathrm{U} 1418 \mathrm{~F}-70 \mathrm{R} \text { through } 72 \mathrm{R} \text { ); } \\
\text { Clasts include quartz, sandstone, metasediment, and greenstone; } \\
\text { Intrastratal contortion and normal faults occur; } \\
\text { Bioturbation is absent; } \\
\text { Only in contact with fall-in sandstone }\end{array}$ & Not documented & IV & Sediment gravity flow \\
\hline
\end{tabular}




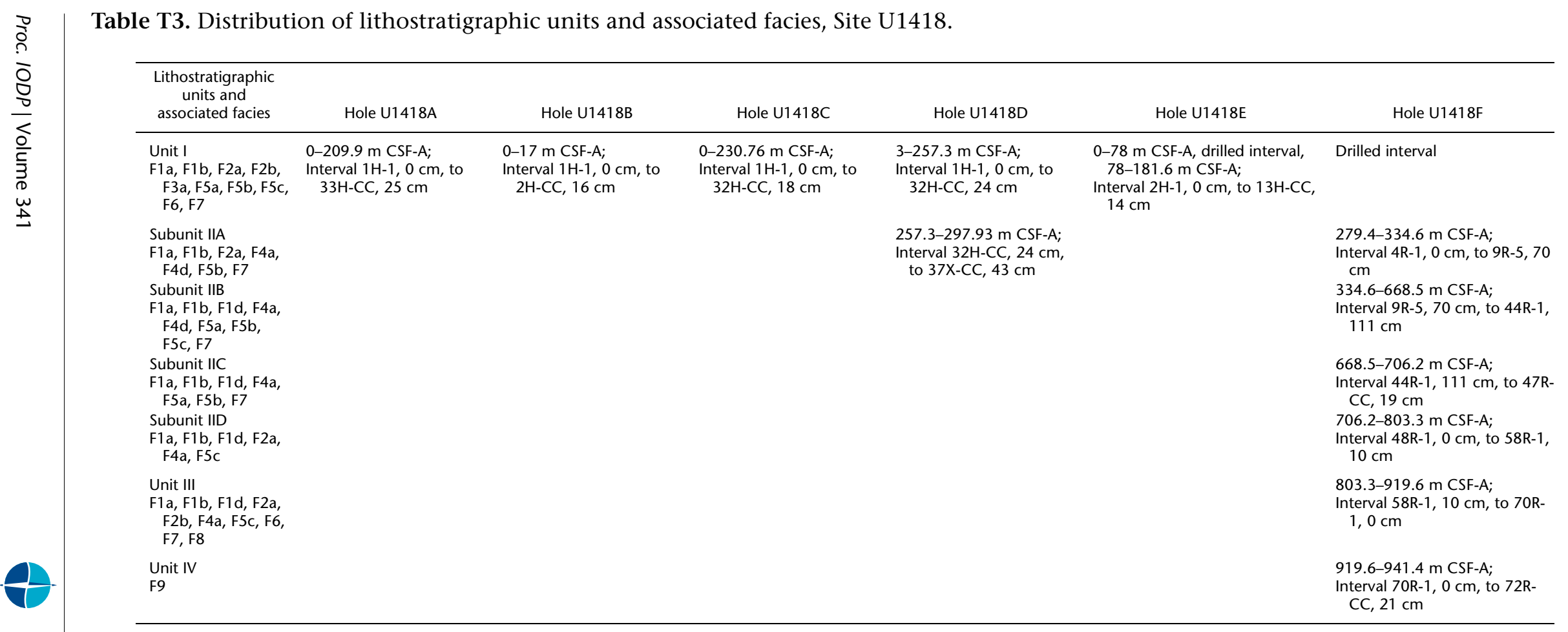

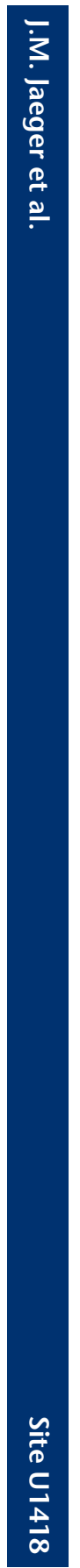


Table T4. X-ray diffraction mineral composition, Holes U1418A, U1418C, U1418D, and U1418E. (Continued on next page.)

\begin{tabular}{|c|c|c|c|c|c|c|c|c|c|c|}
\hline \multirow{2}{*}{$\begin{array}{c}\text { Hole, core, section, } \\
\text { interval }(\mathrm{cm})\end{array}$} & \multicolumn{2}{|c|}{ Top depth (m) } & \multirow{2}{*}{$\begin{array}{c}\text { Mica } \\
\text { (counts) }\end{array}$} & \multirow{2}{*}{$\begin{array}{l}\text { Hornblende } \\
\text { (counts) }\end{array}$} & \multirow{2}{*}{$\begin{array}{l}\text { Chlorite + } \\
\text { kaolinite } \\
\text { (counts) }\end{array}$} & \multirow{2}{*}{$\begin{array}{l}\text { Total clays } \\
\text { (counts) }\end{array}$} & \multirow{2}{*}{$\begin{array}{c}\text { Quartz } \\
\text { (counts) }\end{array}$} & \multirow{2}{*}{$\begin{array}{l}\text { Plagioclase } \\
\text { (counts) }\end{array}$} & \multirow{2}{*}{$\begin{array}{c}\text { Calcite } \\
\text { (counts) }\end{array}$} & \\
\hline & CSF-A & CCSF-B & & & & & & & & (counts) \\
\hline $341-$ & & & & & & & & & & \\
\hline U1418A-1H-2, 90-92 & 2.40 & 2.10 & 5,485 & 4,577 & 7,617 & 2,820 & 5,765 & 6,359 & 4,507 & 2,379 \\
\hline U1418A-2H-4, 71-72 & 10.01 & 10.39 & 4,612 & 5,031 & 7,267 & 2,980 & 6,324 & 6,743 & 3,634 & 2,655 \\
\hline U1418A-3H-3, 50-52 & 17.80 & 18.99 & 4,891 & 4,158 & 6,918 & 2,931 & 7,023 & 7,197 & 3,172 & 2,456 \\
\hline U1418A-4H-3, 48-50 & 27.28 & 27.96 & 4,752 & 4,891 & 7,232 & 2,998 & 6,149 & 6,603 & 3,487 & 2,694 \\
\hline U1418A-5H-1, 41-41 & 33.71 & 35.09 & 4,577 & 3,599 & 6,813 & 3,078 & 6,988 & 6,743 & 3,773 & 2,379 \\
\hline U1418A-5H-1, 85-85 & 34.15 & 35.48 & 6,568 & 4,158 & 5,276 & 1,764 & 10,726 & 14,115 & 4,647 & 1,492 \\
\hline U1418A-5H-2, 50-50 & 35.30 & 36.49 & 6,149 & 3,843 & 8,036 & 3,085 & 6,603 & 6,743 & 3,162 & 2,435 \\
\hline U1418A-5H-5, 48-48 & 39.78 & 40.43 & 4,926 & 7,232 & 7,023 & 2,582 & 6,394 & 8,141 & 3,878 & 2,781 \\
\hline U1418A-5H-5, 81-81 & 40.11 & 40.72 & 7,407 & 7,302 & 8,315 & 2,484 & 6,953 & 12,753 & 2,694 & 1,918 \\
\hline U1418A-5H-5, 115-115 & 40.45 & 41.02 & 6,324 & 5,555 & 8,909 & 2,854 & 5,485 & 6,988 & 4,123 & 2,753 \\
\hline U1418A-6H-1, 55-56 & 43.35 & 44.80 & 5,590 & 5,136 & 8,455 & 2,868 & 6,464 & 7,232 & 2,851 & 2,393 \\
\hline U1418A-6H-4, 59-60 & 48.28 & 49.14 & 8,350 & 4,542 & 11,145 & 3,071 & 7,058 & 7,337 & 3,305 & 2,390 \\
\hline U1418A-7H-1, 44-46 & 52.74 & 53.86 & 4,228 & 4,891 & 6,219 & 2,875 & 6,079 & 6,499 & 3,564 & 2,516 \\
\hline U1418A-7H-5, 80-80 & 59.10 & 59.61 & 3,274 & 3,379 & 4,437 & 2,886 & 6,219 & 6,568 & NA & 2,781 \\
\hline U1418A-7H-7, 27-29 & 61.57 & 61.62 & 5,870 & 7,372 & 9,503 & 2,921 & 6,184 & 7,791 & 3,469 & 2,732 \\
\hline U1418A-11H-1, 70-72 & 91.00 & 89.83 & 4,612 & 5,136 & 7,023 & 2,966 & 6,219 & 6,743 & 3,843 & 2,659 \\
\hline U1418A-12H-4, 114-116 & 105.44 & 104.76 & 4,926 & 5,381 & 6,499 & 2,921 & 6,289 & 7,127 & 2,341 & 2,711 \\
\hline U1418A-13H-3, 22-24 & 111.73 & 112.90 & 4,717 & 4,332 & 6,883 & 3,092 & 5,940 & 6,324 & 3,106 & 2,519 \\
\hline U1418A-13H-7, 66-68 & 116.88 & 117.43 & 5,136 & 3,529 & 6,219 & 2,785 & 8,036 & 7,197 & 3,232 & 2,198 \\
\hline U1418A-14H-3, 36-38 & 121.76 & 122.39 & 4,472 & 4,332 & 6,708 & 3,001 & 6,953 & 6,638 & 2,697 & 2,247 \\
\hline U1418A-15H-3, 19-21 & 126.29 & 127.07 & 4,822 & 5,101 & 7,302 & 2,994 & 5,800 & 6,848 & 3,029 & 2,875 \\
\hline U1418A-16H-1, 35-37 & 128.15 & 128.97 & 5,066 & 5,101 & 7,791 & 3,008 & 5,974 & 6,603 & 3,092 & 2,795 \\
\hline U1418A-17H-1, 4-42 & 132.90 & 133.79 & 5,206 & 4,507 & 7,547 & 2,970 & 6,883 & 6,848 & 2,746 & 2,428 \\
\hline U1418A-18H-2, 24-26 & 138.94 & 139.92 & 5,346 & 4,542 & 8,280 & 3,127 & 6,324 & 6,813 & 2,778 & 2,820 \\
\hline U1418A-19H-1, 26-28 & 142.16 & 143.05 & 4,647 & 4,577 & 7,826 & 3,089 & 6,289 & 6,988 & 2,809 & 2,634 \\
\hline U1418A-20H-1, 20-22 & 146.80 & 147.64 & 4,787 & 4,961 & 7,652 & 2,984 & 6,114 & 6,534 & 2,750 & 2,785 \\
\hline U1418A-21H-4, 50-52 & 155.90 & 155.87 & 4,332 & 5,450 & 6,429 & 2,931 & 6,219 & 6,254 & 3,117 & 2,809 \\
\hline U1418D-22H-3, 56-58 & 192.60 & 191.25 & 6,079 & 3,634 & 9,888 & 3,127 & 6,324 & 6,813 & 2,889 & 2,351 \\
\hline U1418D-23H-2, 47-49 & 198.27 & 197.86 & 5,031 & 5,136 & 7,861 & 2,973 & 5,835 & 6,603 & 3,878 & 2,764 \\
\hline U1418A-31H-3, 30-32 & 201.60 & 202.73 & 6,009 & 4,193 & 8,874 & 2,984 & 6,918 & 7,058 & 2,984 & 2,379 \\
\hline U1418D-24H-1, 60-62 & 204.40 & 204.89 & 6,044 & 4,437 & 9,503 & 3,214 & 7,197 & 7,267 & 3,075 & 2,149 \\
\hline U1418A-32H-2, 74-76 & 205.04 & 205.68 & 4,507 & 5,136 & 6,953 & 2,980 & 5,905 & 6,394 & 3,316 & 2,816 \\
\hline U1418A-33H-2, 58-60 & 208.18 & 209.21 & 5,206 & 3,564 & 7,721 & 3,064 & 6,289 & 6,324 & 3,218 & 2,344 \\
\hline U1418D-25H-5, 89-90 & 218.69 & 218.22 & 6,673 & 4,018 & 9,468 & 2,921 & 6,778 & 6,743 & 2,994 & 2,390 \\
\hline U1418D-26H-5, 33-34 & 226.93 & 226.95 & 4,822 & 5,520 & 7,023 & 2,952 & 5,346 & 6,743 & 3,773 & 2,879 \\
\hline U1418D-28H-2, 63-64 & 236.83 & 236.83 & 7,023 & 4,752 & 9,992 & 3,012 & 6,464 & 6,918 & 3,235 & 2,449 \\
\hline U1418D-29H-1, 106-107 & 240.46 & 240.46 & 7,162 & 4,647 & 9,154 & 2,900 & 6,638 & 7,791 & 2,778 & 2,414 \\
\hline U1418D-30H-1, 46-48 & 244.56 & 244.56 & 4,542 & 3,913 & 6,918 & 3,228 & 6,219 & 6,464 & 2,844 & 2,488 \\
\hline U1418D-31H-3, 50-52 & 252.10 & 252.10 & 4,752 & 5,171 & 7,756 & 3,130 & 6,184 & 6,568 & 3,420 & 2,886 \\
\hline U1418D-32H-2, 84-85 & 255.64 & 255.64 & 4,577 & 4,996 & 7,267 & 2,977 & 6,429 & 7,023 & 3,564 & 2,634 \\
\hline U1418D-33X-2, 45-47 & 259.25 & 259.25 & 4,297 & 5,241 & 6,464 & 2,893 & 6,009 & 6,568 & 3,843 & 2,778 \\
\hline U1418D-34X-2, 46-48 & 268.96 & 268.96 & 5,520 & 4,193 & 7,826 & 3,064 & 7,058 & 8,665 & 3,036 & 2,537 \\
\hline U1418D-35X-2, 53-55 & 278.73 & 278.73 & 4,612 & 3,738 & 7,023 & 3,242 & 6,184 & 6,568 & 2,827 & 2,418 \\
\hline U1418F-4R-2, 114-115 & 282.04 & 282.04 & 6,883 & 5,800 & 9,049 & 2,739 & 5,695 & 6,848 & 2,963 & 2,568 \\
\hline U1418D-36X-2, 37-39 & 288.27 & 288.27 & 8,280 & 5,066 & 12,159 & 2,938 & 7,023 & 8,176 & 2,750 & 2,355 \\
\hline U1418F-6R-2, 55-56 & 300.85 & 300.85 & 5,870 & 3,948 & 8,735 & 3,015 & 6,778 & 6,673 & 3,354 & 2,484 \\
\hline U1418F-7R-3, 28-30 & 311.78 & 311.78 & 5,590 & 4,507 & 8,280 & 2,963 & 6,708 & 6,918 & 3,089 & 2,404 \\
\hline U1418F-8R-1，47-49 & 318.67 & 318.67 & 5,276 & 5,485 & 5,311 & 2,847 & 5,415 & 6,883 & 2,313 & 2,854 \\
\hline U1418F-9R-3, 32-34 & 331.22 & 331.22 & 5,625 & 4,682 & 8,665 & 2,966 & 6,289 & 6,464 & 2,261 & 2,281 \\
\hline U1418F-10R-4, 37-39 & 342.47 & 342.47 & 6,044 & 6,534 & 7,127 & 3,001 & 5,974 & 6,638 & 3,466 & 2,655 \\
\hline U1418F-11R-3, 71-73 & 351.01 & 351.01 & 4,961 & 5,485 & 11,774 & 2,914 & 5,835 & 7,512 & 2,795 & 2,861 \\
\hline U1418F-12R-3, 60-62 & 360.60 & 360.60 & 4,996 & 4,926 & 7,547 & 2,949 & 6,324 & 7,442 & 3,183 & 2,222 \\
\hline U1418F-13R-3, 56-58 & 370.26 & 370.26 & 4,437 & 5,625 & 8,455 & 2,956 & 5,835 & 8,036 & 2,809 & 2,764 \\
\hline U1418F-14R-3, 55-57 & 379.95 & 379.95 & 7,162 & 8,560 & 15,757 & 2,827 & 5,835 & 6,184 & 3,099 & 3,288 \\
\hline U1418F-15R-3, 98-100 & 390.08 & 390.08 & 4,822 & 6,219 & 6,813 & 3,050 & 5,695 & 7,337 & 3,494 & 2,393 \\
\hline U1418F-16R-6, 53-55 & 403.76 & 403.76 & 4,472 & 5,206 & 6,848 & 3,148 & 6,499 & 6,813 & 3,103 & 2,491 \\
\hline U1418F-17R-6, 24-26 & 413.25 & 413.25 & 5,625 & 4,263 & 7,756 & 3,026 & 6,044 & 6,848 & 3,137 & 2,526 \\
\hline U1418F-18R-6, 112-114 & 423.82 & 423.82 & 5,171 & 8,071 & 8,106 & 3,022 & 7,093 & 7,337 & 2,984 & 3,179 \\
\hline U1418F-19R-3, 61-63 & 428.51 & 428.51 & 5,381 & 4,193 & 8,141 & 3,078 & 5,974 & 8,665 & 2,952 & 2,959 \\
\hline U1418F-20R-3, 29-31 & 437.89 & 437.89 & 4,332 & 6,289 & 8,176 & 2,984 & 6,778 & 6,044 & 2,823 & 2,886 \\
\hline U1418F-21R-3, 85-87 & 448.15 & 448.15 & 5,625 & 5,800 & 10,586 & 3,141 & 5,800 & 6,464 & 4,193 & 1,810 \\
\hline U1418F-22R-3, 44-46 & 457.44 & 457.44 & 4,647 & 5,590 & 8,176 & 2,991 & 6,219 & 8,805 & 2,949 & 3,155 \\
\hline U1418F-23R-3, 31-33 & 467.01 & 467.01 & 4,437 & 5,800 & 7,896 & 3,277 & 6,534 & 6,254 & 3,634 & 2,725 \\
\hline U1418F-24R-2, 30-32 & 475.20 & 475.20 & 4,612 & 3,948 & 7,372 & 2,708 & 6,009 & 6,603 & 3,270 & 2,771 \\
\hline U1418F-25R-3, 47-49 & 486.57 & 486.57 & 5,031 & 9,888 & 7,826 & 3,365 & 5,730 & 7,372 & 4,228 & 2,764 \\
\hline U1418F-26R-3, 90-92 & 496.70 & 496.70 & 5,940 & 5,905 & 6,464 & 2,956 & 5,346 & 6,534 & 3,427 & 3,197 \\
\hline
\end{tabular}


Table T4 (continued).

\begin{tabular}{|c|c|c|c|c|c|c|c|c|c|c|}
\hline \multirow{2}{*}{$\begin{array}{l}\text { Hole, core, section, } \\
\text { interval }(\mathrm{cm})\end{array}$} & \multicolumn{2}{|c|}{ Top depth (m) } & \multirow{2}{*}{$\begin{array}{c}\text { Mica } \\
\text { (counts) }\end{array}$} & \multirow{2}{*}{$\begin{array}{l}\text { Hornblende } \\
\text { (counts) }\end{array}$} & \multirow{2}{*}{$\begin{array}{c}\text { Chlorite + } \\
\text { kaolinite } \\
\text { (counts) }\end{array}$} & \multirow{2}{*}{$\begin{array}{l}\text { Total clays } \\
\text { (counts) }\end{array}$} & \multirow{2}{*}{$\begin{array}{l}\text { Quartz } \\
\text { (counts) }\end{array}$} & \multirow{2}{*}{$\begin{array}{l}\text { Plagioclase } \\
\text { (counts) }\end{array}$} & \multirow{2}{*}{$\begin{array}{l}\text { Calcite } \\
\text { (counts) }\end{array}$} & \multirow{2}{*}{$\begin{array}{l}\text { Pyrite } \\
\text { (counts) }\end{array}$} \\
\hline & CSF-A & CCSF-B & & & & & & & & \\
\hline U1418F-27R-4, 96-98 & 507.96 & 507.96 & 4,437 & 3,358 & 8,979 & 3,186 & 5,660 & 8,211 & 3,529 & 2,676 \\
\hline U1418F-28R-4, 72-74 & 517.42 & 517.42 & 6,638 & 3,878 & 9,748 & 3,214 & 5,940 & 7,686 & 3,347 & 2,980 \\
\hline U1418F-29R-5, 64-66 & 528.54 & 528.54 & 5,066 & 7,127 & 6,534 & 3,172 & 6,184 & 7,721 & 3,494 & 2,425 \\
\hline U1418F-30R-2, 99-101 & 534.09 & 534.09 & 4,856 & 5,870 & 8,595 & 2,921 & 5,940 & 6,638 & 2,952 & 3,068 \\
\hline U1418F-32R-3, 59-61 & 554.59 & 554.59 & 5,485 & 6,988 & 9,503 & 3,036 & 6,079 & 6,813 & 3,445 & 2,718 \\
\hline U1418F-33R-3, 45-47 & 564.15 & 564.15 & 4,996 & NA & 7,896 & 2,959 & 7,337 & 7,127 & 3,368 & 2,372 \\
\hline U1418F-34R-3, 38-40 & 573.78 & 573.78 & 4,891 & 5,590 & 7,477 & 2,830 & 5,870 & 6,743 & 2,610 & 3,022 \\
\hline U1418F-35R-3, 45-47 & 583.55 & 583.55 & 4,891 & 7,652 & 7,442 & 2,910 & 6,534 & 6,568 & 2,652 & 2,931 \\
\hline U1418F-36R-3, 70-72 & 593.50 & 593.50 & 5,066 & 4,507 & 7,966 & 2,921 & 5,590 & 6,918 & 3,337 & 2,921 \\
\hline U1418F-37R-3, 107-109 & 603.57 & 603.57 & 6,464 & 6,359 & 7,058 & 2,893 & 6,219 & 6,813 & 2,875 & 2,491 \\
\hline U1418F-38R-3, 73-75 & 612.93 & 612.93 & 5,206 & 5,695 & 8,700 & 2,900 & 5,555 & 6,743 & NA & 2,708 \\
\hline U1418F-39R-1, 69-71 & 619.59 & 619.59 & 4,402 & 6,289 & 7,477 & 2,942 & 5,835 & 6,638 & 3,878 & 2,799 \\
\hline U1418F-40R-6, 75-77 & 636.78 & 636.78 & 5,171 & 15,024 & 10,132 & 2,746 & 5,695 & 6,359 & 3,200 & 2,341 \\
\hline U1418F-41R-6, 47-49 & 646.25 & 646.25 & 5,276 & 6,953 & 13,836 & 3,047 & 5,241 & 6,953 & 3,330 & 3,214 \\
\hline U1418F-43R-2, 46-48 & 659.66 & 659.66 & 4,926 & 5,940 & 7,721 & 2,858 & 5,031 & 7,267 & 3,029 & 2,858 \\
\hline U1418F-44R-5, 113-115 & 674.39 & 674.39 & 4,752 & 6,359 & 6,673 & 2,882 & 6,149 & 6,673 & 3,050 & 2,488 \\
\hline U1418F-45R-1, 24-26 & 677.34 & 677.34 & 5,800 & 4,297 & 7,791 & 2,914 & 6,114 & 6,289 & 3,130 & 2,295 \\
\hline U1418F-46R-2, 14-16 & 688.44 & 688.44 & 7,372 & 5,800 & 7,477 & 2,847 & 6,708 & 7,058 & NA & 2,900 \\
\hline U1418F-47R-3, 47-49 & 699.97 & 699.97 & 8,246 & 6,044 & 7,686 & 3,134 & 6,289 & 7,826 & 2,956 & 2,680 \\
\hline U1418F-47R-6, 142-143 & 705.41 & 705.41 & 6,079 & 7,232 & 8,315 & 2,994 & 6,289 & 8,455 & 3,082 & 2,809 \\
\hline U1418F-48R-3, 51-53 & 709.49 & 709.49 & 4,856 & 2,854 & 8,141 & 2,963 & 5,940 & 6,883 & 3,029 & 2,785 \\
\hline U1418F-49R-3, 75-77 & 719.41 & 719.41 & 5,031 & 5,241 & 7,197 & 3,099 & 6,079 & 7,512 & 3,190 & 2,299 \\
\hline U1418F-50R-3, 75-77 & 729.17 & 729.17 & 5,171 & 3,773 & 7,617 & 3,106 & 7,197 & 6,848 & NA & 2,701 \\
\hline U1418F-50R-5, 119-119 & 732.55 & 732.55 & 2,970 & 4,856 & 7,337 & 3,050 & 6,603 & 6,359 & 3,599 & 2,337 \\
\hline U1418F-50R-5, 124-124 & 732.60 & 732.60 & 3,347 & 5,695 & 8,176 & 3,075 & 5,940 & 6,534 & 2,257 & 2,935 \\
\hline U1418F-51R-3, 70-72 & 738.73 & 738.73 & 5,066 & 5,241 & 8,805 & 3,036 & 6,988 & 5,381 & 3,386 & 2,722 \\
\hline U1418F-52R-3, 65-67 & 748.52 & 748.52 & 5,415 & 4,123 & 9,468 & 3,033 & 6,289 & 6,429 & $3, j 312$ & 2,624 \\
\hline U1418F-53R-3, 39-41 & 758.03 & 758.03 & 6,079 & 6,219 & 7,721 & 2,795 & 6,289 & 7,127 & 3,316 & 3,061 \\
\hline U1418F-54R-4, 71-73 & 769.28 & 769.28 & 4,996 & 4,891 & 7,093 & 2,896 & 6,359 & 7,058 & 3,281 & 2,254 \\
\hline U1418F-55R-6, 31-33 & 781.85 & 781.85 & 8,071 & 3,738 & 7,652 & 2,254 & 5,381 & 9,818 & 3,124 & 2,383 \\
\hline U1418F-56R-5, 82-84 & 790.39 & 790.39 & 4,612 & 4,717 & 7,686 & 2,970 & 5,765 & 6,429 & 3,291 & 3,211 \\
\hline U1418F-57R-3, 58-60 & 797.06 & 797.06 & 5,276 & 7,791 & 11,006 & 3,120 & 5,555 & 6,778 & 3,808 & 2,823 \\
\hline U1418F-58R-3, 54-56 & 806.69 & 806.69 & 7,058 & 6,009 & 6,394 & 2,987 & 6,603 & 8,211 & 3,529 & 2,708 \\
\hline U1418F-59R-4, 57-59 & 817.97 & 817.97 & 5,555 & 6,534 & 7,617 & 2,984 & 6,219 & 6,918 & 3,026 & 3,344 \\
\hline U1418F-60R-1, 82-84 & 823.42 & 823.42 & 6,254 & 4,996 & 9,957 & 2,827 & 6,673 & 6,603 & 3,204 & 2,655 \\
\hline U1418F-61R-2, 9-11 & 833.84 & 833.84 & 5,066 & 3,309 & 6,429 & 3,165 & 6,044 & 7,232 & 3,117 & 2,690 \\
\hline U1418F-62R-1, 69-71 & 842.69 & 842.69 & 5,765 & 2,564 & 4,787 & 3,134 & 5,835 & 6,708 & 3,703 & 2,676 \\
\hline U1418F-63R-1, 36-38 & 852.06 & 852.06 & 4,996 & 5,660 & 7,756 & 3,068 & 5,625 & 6,673 & 3,064 & 2,442 \\
\hline U1418F-64R-1, 63-65 & 862.03 & 862.03 & 4,891 & 8,246 & 4,018 & 2,935 & 5,520 & 6,638 & 2,809 & 3,127 \\
\hline U1418F-65R-1, 57-59 & 871.67 & 871.67 & 5,136 & 9,538 & 14,045 & 2,613 & 6,638 & 6,673 & 2,959 & 3,033 \\
\hline U1418F-66R-1, 32-34 & 881.12 & 881.12 & 4,472 & 5,905 & 6,114 & 2,854 & 6,848 & 7,127 & 8,036 & 2,792 \\
\hline U1418F-69R-3, 66-67 & 913.26 & 913.26 & 4,577 & 4,053 & 8,770 & 3,085 & 6,918 & 9,364 & 3,358 & 3,008 \\
\hline
\end{tabular}

NA = not applicable. 
Table T5. Diatom, radiolarian, and foraminiferal datum events, Site U1418.

\begin{tabular}{|c|c|c|c|c|c|c|c|c|c|c|c|c|c|}
\hline \multirow[b]{3}{*}{ Datum event } & \multirow{3}{*}{$\begin{array}{c}\text { Datum } \\
\text { type }\end{array}$} & \multirow{3}{*}{$\begin{array}{l}\text { Age } \\
(\mathrm{Ma})\end{array}$} & \multirow{2}{*}{\multicolumn{2}{|c|}{ Hole, core, section, interval $(\mathrm{cm})$}} & \multicolumn{3}{|c|}{ Depth CSF-A (m) } & \multicolumn{3}{|c|}{ Depth CCSF-A (m) } & \multicolumn{3}{|c|}{ Depth CCSF-B (m) } \\
\hline & & & & & \multirow{2}{*}{$\begin{array}{c}\text { Top } \\
\text { (middle) }\end{array}$} & \multirow{2}{*}{$\begin{array}{l}\text { Bottom } \\
\text { (middle) }\end{array}$} & \multirow[b]{2}{*}{ Median } & \multirow{2}{*}{$\begin{array}{c}\text { Top } \\
\text { (middle) }\end{array}$} & \multirow{2}{*}{$\begin{array}{l}\text { Bottom } \\
\text { (middle) }\end{array}$} & \multirow[b]{2}{*}{ Median } & \multirow{2}{*}{$\begin{array}{c}\text { Top } \\
\text { (middle) }\end{array}$} & \multirow{2}{*}{$\begin{array}{l}\text { Bottom } \\
\text { (middle) }\end{array}$} & \multirow[b]{2}{*}{ Median } \\
\hline & & & Top & Bottom & & & & & & & & & \\
\hline & & & $341-$ & $341-$ & & & & & & & & & \\
\hline LO Lychnocanoma nipponica sakaii & $\mathrm{R}$ & $0.03 \pm 0.03$ & U1418A-7H-CC & U1418D-9H-CC & 62.17 & 77.11 & 69.64 & 70.66 & 85.52 & 78.09 & 62.15 & 75.21 & 68.68 \\
\hline LO Proboscia curvirostris (D120) & D & $0.3 \pm 0.1$ & U1418F-4R-2, 100 & U1418F-11R-2, 100 & 330.40 & 349.80 & 340.10 & 372.49 & 391.89 & 382.19 & 330.40 & 349.80 & 340.10 \\
\hline LO Stylacontharium aquilonium & $\mathrm{R}$ & $0.4 \pm 0.1$ & U1418F-11R-CC & U1418F-17R-CC & 354.82 & 414.65 & 384.73 & 396.91 & 456.74 & 426.82 & 354.82 & 414.65 & 384.73 \\
\hline LO Stylatractus universus & $\mathrm{R}$ & $0.5 \pm 0.1$ & U1418F-18R-CC & U1418F-27R-CC & 424.13 & 509.83 & 466.98 & 466.22 & 551.92 & 509.07 & 424.13 & 509.83 & 466.98 \\
\hline LO Neogloboquadrina inglei & $\mathrm{F}$ & $0.7 \pm 0.1$ & U1418F-39R-CC & U1418F-40R-CC & 625.88 & 638.32 & 632.10 & 667.97 & 680.41 & 674.19 & 625.88 & 638.32 & 632.10 \\
\hline
\end{tabular}

$\mathrm{LO}=$ last occurrence. $\mathrm{D}=$ diatom, $\mathrm{F}=$ foraminifer, $\mathrm{R}=$ radiolarian .

Table T6. Diatoms, Site U1418. This table is available in an oversized format.

Table T7. Radiolarians, Site U1418. This table is available in an oversized format. 
Table T8. Planktonic foraminifers, Site U1418.

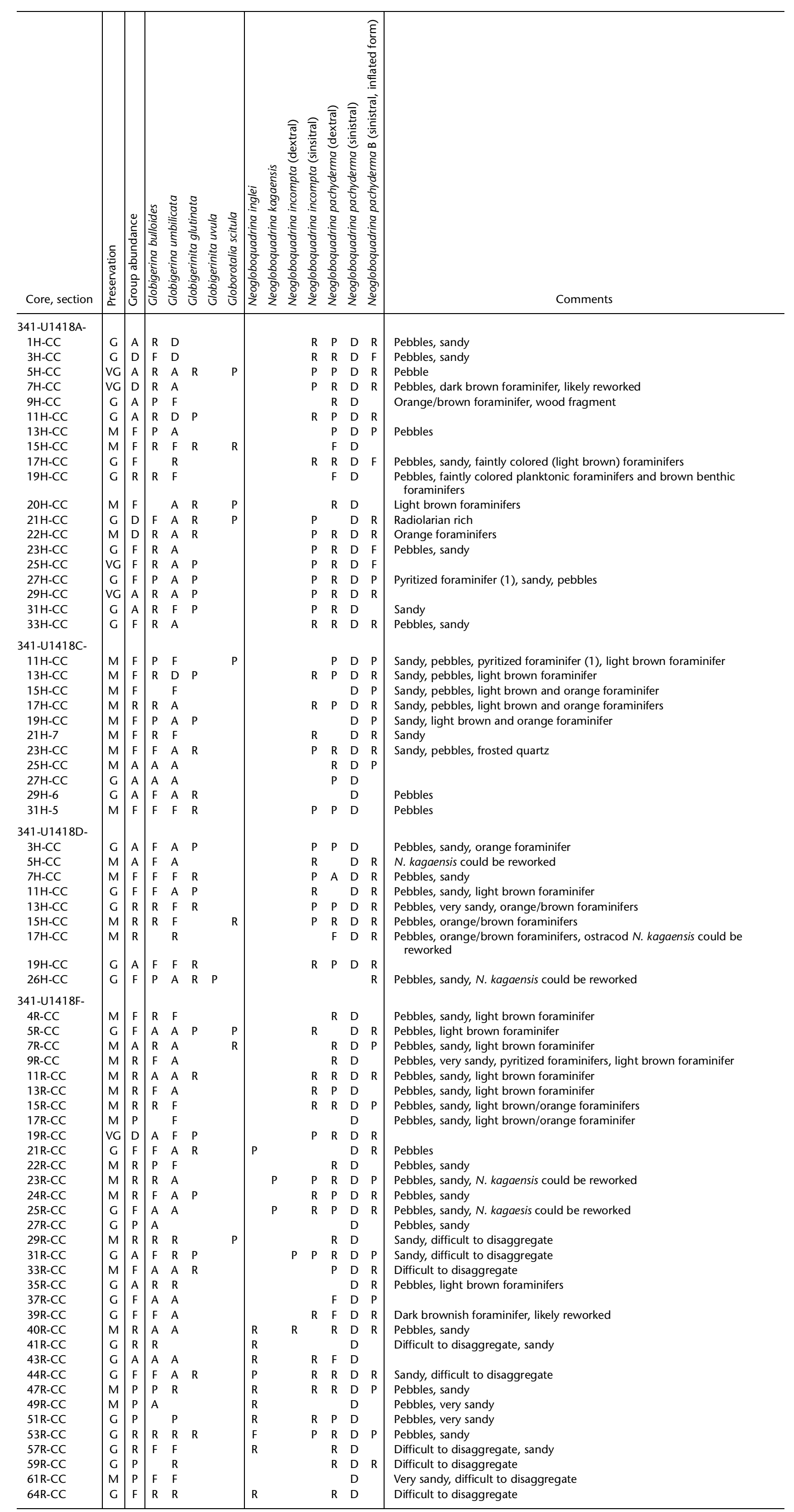

Preservation: $V G=$ very good, $G=$ good, $M=$ moderate. Abundance: $D=$ dominant, $A=$ abundant,$C=$ common, $F=$ few, $R=$ rare, $P=$ present. This table is also available in.$C S V$. 
Table T9. Benthic foraminifers, Site U1418. This table is available in an oversized format. 
Table T10. Affine table, Site U1418.

\begin{tabular}{|c|c|}
\hline Core & Offset (m) \\
\hline \multicolumn{2}{|c|}{ 341-U1418A- } \\
\hline $1 \mathrm{H}$ & -0.01 \\
\hline $2 \mathrm{H}$ & 1.80 \\
\hline $3 \mathrm{H}$ & 3.79 \\
\hline $4 \mathrm{H}$ & 4.51 \\
\hline $5 \mathrm{H}$ & 6.19 \\
\hline $6 \mathrm{H}$ & 7.59 \\
\hline $7 \mathrm{H}$ & 8.50 \\
\hline $8 \mathrm{H}$ & 9.86 \\
\hline $9 \mathrm{H}$ & 10.74 \\
\hline $10 \mathrm{H}$ & 11.54 \\
\hline $11 \mathrm{H}$ & 11.15 \\
\hline $12 \mathrm{H}$ & 13.68 \\
\hline $13 \mathrm{H}$ & 16.64 \\
\hline $14 \mathrm{H}$ & 17.41 \\
\hline $15 \mathrm{H}$ & 18.20 \\
\hline $16 \mathrm{H}$ & 18.50 \\
\hline $17 \mathrm{H}$ & 19.23 \\
\hline $18 \mathrm{H}$ & 20.81 \\
\hline $19 \mathrm{H}$ & 21.49 \\
\hline $20 \mathrm{H}$ & 22.58 \\
\hline $21 \mathrm{H}$ & 23.74 \\
\hline $22 \mathrm{H}$ & 24.23 \\
\hline $23 \mathrm{H}$ & 23.86 \\
\hline $24 \mathrm{H}$ & 25.00 \\
\hline $25 \mathrm{H}$ & 26.55 \\
\hline $26 \mathrm{H}$ & 27.90 \\
\hline $27 \mathrm{H}$ & 29.98 \\
\hline $28 \mathrm{H}$ & 30.77 \\
\hline $29 \mathrm{H}$ & 32.80 \\
\hline $30 \mathrm{H}$ & 34.93 \\
\hline $31 \mathrm{H}$ & 36.49 \\
\hline $32 \mathrm{H}$ & 36.74 \\
\hline $33 \mathrm{H}$ & 37.99 \\
\hline \multicolumn{2}{|c|}{ 341-U1418B- } \\
\hline $1 \mathrm{H}$ & -0.02 \\
\hline $2 \mathrm{H}$ & 2.14 \\
\hline \multicolumn{2}{|c|}{ 341-U1418C- } \\
\hline $1 \mathrm{H}$ & 0.00 \\
\hline $2 \mathrm{H}$ & 1.39 \\
\hline $3 \mathrm{H}$ & 1.61 \\
\hline $4 \mathrm{H}$ & 2.61 \\
\hline $5 \mathrm{H}$ & 3.82 \\
\hline $6 \mathrm{H}$ & 4.17 \\
\hline $7 \mathrm{H}$ & 6.30 \\
\hline 81 & No core recovery \\
\hline $9 \mathrm{H}$ & 6.46 \\
\hline $10 \mathrm{H}$ & 8.60 \\
\hline $11 \mathrm{H}$ & 9.54 \\
\hline $12 \mathrm{H}$ & 10.35 \\
\hline $13 \mathrm{H}$ & 10.89 \\
\hline $14 \mathrm{H}$ & 11.56 \\
\hline $15 \mathrm{H}$ & 13.29 \\
\hline $16 \mathrm{H}$ & 13.81 \\
\hline $17 \mathrm{H}$ & 15.04 \\
\hline $18 \mathrm{H}$ & 15.61 \\
\hline $19 \mathrm{H}$ & 16.20 \\
\hline $20 \mathrm{H}$ & 15.55 \\
\hline $21 \mathrm{H}$ & 16.37 \\
\hline $22 \mathrm{H}$ & 18.24 \\
\hline $23 \mathrm{H}$ & 21.62 \\
\hline $24 \mathrm{H}$ & 24.12 \\
\hline $25 \mathrm{H}$ & 26.07 \\
\hline $26 \mathrm{H}$ & 28.28 \\
\hline $27 \mathrm{H}$ & 30.29 \\
\hline $28 \mathrm{H}$ & 31.57 \\
\hline
\end{tabular}

\begin{tabular}{|c|c|c|c|}
\hline Core & Offset (m) & Core & Offset (m) \\
\hline $29 \mathrm{H}$ & 34.51 & $14 \mathrm{R}$ & 42.09 \\
\hline $30 \mathrm{H}$ & 36.23 & $15 \mathrm{R}$ & 42.09 \\
\hline $31 \mathrm{H}$ & 38.78 & $16 \mathrm{R}$ & 42.09 \\
\hline $32 \mathrm{H}$ & 40.88 & $17 R$ & 42.09 \\
\hline 341-U1418D- & & $18 \mathrm{R}$ & 42.09 \\
\hline $2 \mathrm{H}$ & 1.98 & $19 \mathrm{R}$ & 42.09 \\
\hline $3 \mathrm{H}$ & 2.72 & $20 \mathrm{R}$ & 42.09 \\
\hline $4 \mathrm{H}$ & 3.77 & $21 \mathrm{R}$ & 42.09 \\
\hline $5 \mathrm{H}$ & 4.86 & $22 \mathrm{R}$ & 42.09 \\
\hline $6 \mathrm{H}$ & 5.72 & $23 \mathrm{R}$ & 42.09 \\
\hline $7 \mathrm{H}$ & 6.27 & $24 \mathrm{R}$ & 42.09 \\
\hline $8 \mathrm{H}$ & 7.20 & $25 \mathrm{R}$ & 42.09 \\
\hline $9 \mathrm{H}$ & 8.41 & $26 \mathrm{R}$ & 42.09 \\
\hline $10 \mathrm{H}$ & 9.89 & $27 \mathrm{R}$ & 42.09 \\
\hline $11 \mathrm{H}$ & 11.24 & $28 \mathrm{R}$ & 42.09 \\
\hline $12 \mathrm{H}$ & 13.80 & $29 \mathrm{R}$ & 42.09 \\
\hline $13 \mathrm{H}$ & 15.74 & $30 \mathrm{R}$ & 42.09 \\
\hline $14 \mathrm{H}$ & 15.84 & $31 \mathrm{R}$ & 42.09 \\
\hline $15 \mathrm{H}$ & 17.75 & $32 \mathrm{R}$ & 42.09 \\
\hline $16 \mathrm{H}$ & 19.19 & $33 \mathrm{R}$ & 42.09 \\
\hline $17 \mathrm{H}$ & 21.36 & $34 \mathrm{R}$ & 42.09 \\
\hline $18 \mathrm{H}$ & 23.08 & $35 \mathrm{R}$ & 42.09 \\
\hline $19 \mathrm{H}$ & 23.94 & $36 \mathrm{R}$ & 42.09 \\
\hline $20 \mathrm{H}$ & 25.95 & $37 \mathrm{R}$ & 42.09 \\
\hline $21 \mathrm{H}$ & 28.24 & $38 \mathrm{R}$ & 42.09 \\
\hline $22 \mathrm{H}$ & 31.17 & $39 \mathrm{R}$ & 42.09 \\
\hline $23 \mathrm{H}$ & 33.75 & $40 \mathrm{R}$ & 42.09 \\
\hline $24 \mathrm{H}$ & 36.39 & $41 \mathrm{R}$ & 42.09 \\
\hline $25 \mathrm{H}$ & 38.72 & $42 \mathrm{R}$ & No core recovery \\
\hline $26 \mathrm{H}$ & 41.37 & $43 \mathrm{R}$ & 42.09 \\
\hline $27 \mathrm{H}$ & 42.09 & $44 \mathrm{R}$ & 42.09 \\
\hline $28 \mathrm{H}$ & 42.09 & $45 \mathrm{R}$ & 42.09 \\
\hline $29 \mathrm{H}$ & 42.09 & $46 \mathrm{R}$ & 42.09 \\
\hline $30 \mathrm{H}$ & 42.09 & $47 \mathrm{R}$ & 42.09 \\
\hline $31 \mathrm{H}$ & 42.09 & $48 \mathrm{R}$ & 42.09 \\
\hline $32 \mathrm{H}$ & 42.09 & $49 \mathrm{R}$ & 42.09 \\
\hline $33 x$ & 42.09 & $50 \mathrm{R}$ & 42.09 \\
\hline $34 X$ & 42.09 & $51 \mathrm{R}$ & 42.09 \\
\hline $35 x$ & 42.09 & $52 \mathrm{R}$ & 42.09 \\
\hline $36 x$ & 42.09 & $53 \mathrm{R}$ & 42.09 \\
\hline $37 x$ & 42.09 & $54 \mathrm{R}$ & 42.09 \\
\hline & & $55 \mathrm{R}$ & 42.09 \\
\hline 341-U1418E- & & $56 \mathrm{R}$ & 42.09 \\
\hline $2 \mathrm{H}$ & 9.98 & $57 \mathrm{R}$ & 42.09 \\
\hline 31 & No core recovery & $58 \mathrm{R}$ & 42.09 \\
\hline $4 \mathrm{H}$ & 13.61 & $59 \mathrm{R}$ & 42.09 \\
\hline $5 \mathrm{H}$ & 14.70 & $60 \mathrm{R}$ & 42.09 \\
\hline $6 \mathrm{H}$ & 16.77 & $61 \mathrm{R}$ & 42.09 \\
\hline $7 \mathrm{H}$ & 16.30 & $62 \mathrm{R}$ & 42.09 \\
\hline $8 \mathrm{H}$ & 17.03 & $63 R$ & 42.09 \\
\hline $9 \mathrm{H}$ & 18.82 & $64 \mathrm{R}$ & 42.09 \\
\hline $10 \mathrm{H}$ & 21.84 & $65 \mathrm{R}$ & 42.09 \\
\hline $11 \mathrm{H}$ & 23.80 & $66 \mathrm{R}$ & 42.09 \\
\hline $12 \mathrm{H}$ & 25.69 & $67 \mathrm{R}$ & $2 \%$ recovery \\
\hline $13 \mathrm{H}$ & 29.07 & $68 \mathrm{R}$ & 42.09 \\
\hline 341-U1418F- & & $69 \mathrm{R}$ & 42.09 \\
\hline $4 \mathrm{R}$ & 42.09 & $70 \mathrm{R}$ & 42.09 \\
\hline $5 \mathrm{R}$ & 42.09 & $71 \mathrm{R}$ & 42.09 \\
\hline $6 \mathrm{R}$ & 42.09 & $72 \mathrm{R}$ & 42.09 \\
\hline
\end{tabular}

Core: $\mathrm{H}=$ advanced piston corer, $\mathrm{X}=$ extended core barrel, $\mathrm{R}=$ rotary core barrel. Cores with very low recovery were not used for correlation purposes. 
Table T11. Splice tie points, Site U1418.

\begin{tabular}{|c|c|c|c|c|c|c|c|c|}
\hline $\begin{array}{l}\text { Hole, core, } \\
\text { section }\end{array}$ & $\begin{array}{l}\text { Tie point } \\
(\mathrm{cm})\end{array}$ & $\begin{array}{c}\text { Depth } \\
\text { CSF-A } \\
(\mathrm{m})\end{array}$ & $\begin{array}{l}\text { Depth } \\
\text { CCSF-A } \\
(\mathrm{m})\end{array}$ & Tie/Append & $\begin{array}{l}\text { Hole, core, } \\
\text { section }\end{array}$ & $\begin{array}{l}\text { Tie point } \\
(\mathrm{cm})\end{array}$ & $\begin{array}{l}\text { Depth } \\
\text { CSF-A } \\
(\mathrm{m})\end{array}$ & $\begin{array}{c}\text { Depth } \\
\text { CCSF-A } \\
\text { (m) }\end{array}$ \\
\hline $341-$ & & & & & $341-$ & & & \\
\hline U1418C-1H-5 & 114.51 & 7.15 & 7.15 & Tie to & U1418D-2H-2 & 66.99 & 5.17 & 7.15 \\
\hline U1418D-2H-6 & 72.72 & 11.23 & 13.20 & Tie to & U1418C-2H-3 & 21.24 & 11.81 & 13.20 \\
\hline U1418C-2H-5 & 133.08 & 15.93 & 17.32 & Tie to & U1418D-3H-2 & 60.19 & 14.60 & 17.32 \\
\hline U1418D-3H-6 & 26.72 & 20.27 & 22.99 & Tie to & U1418C-3H-3 & 27.68 & 21.38 & 22.99 \\
\hline U1418C-3H-6 & 76.92 & 26.32 & 27.93 & Tie to & U1418D-4H-2 & 65.56 & 24.16 & 27.93 \\
\hline U1418D-4H-5 & 107.67 & 29.08 & 32.85 & Tie to & U1418C-4H-2 & 113.64 & 30.24 & 32.85 \\
\hline U1418C-4H-6 & 43.46 & 35.53 & 38.15 & Tie to & U1418D-5H-2 & 28.32 & 33.28 & 38.15 \\
\hline U1418D-5H-6 & 127.64 & 40.28 & 45.14 & Tie to & U1418C-5H-3 & 122.09 & 41.32 & 45.14 \\
\hline U1418C-5H-6 & 19.63 & 44.80 & 48.62 & Tie to & U1418D-6H-2 & 39.50 & 42.90 & 48.62 \\
\hline U1418D-6H-5 & 118.82 & 48.19 & 53.91 & Tie to & U1418C-6H-3 & 13.92 & 49.74 & 53.91 \\
\hline U1418C-6H-6 & 48.93 & 54.59 & 58.76 & Tie to & U1418D-7H-2 & 48.90 & 52.49 & 58.76 \\
\hline U1418D-7H-6 & 59.39 & 58.59 & 64.86 & Tie to & U1418A-7H-3 & 106.58 & 56.37 & 64.86 \\
\hline U1418A-7H-5 & 76.18 & 59.06 & 67.56 & Tie to & U1418D-8H-1 & 36.30 & 60.36 & 67.56 \\
\hline U1418D-8H-6 & 36.13 & 67.55 & 74.75 & Tie to & U1418C-9H-1 & 19.18 & 68.29 & 74.75 \\
\hline U1418C-9H-2 & 86.82 & 70.47 & 76.93 & Tie to & U1418D-9H-1 & 61.36 & 68.51 & 76.93 \\
\hline U1418D-9H-5 & 147.80 & 75.38 & 83.79 & Tie to & U1418A-9H-2 & 25.16 & 73.05 & 83.79 \\
\hline U1418A-9H-5 & 80.98 & 78.11 & 88.85 & Tie to & U1418E-2H-1 & 86.53 & 78.87 & 88.85 \\
\hline U1418E-2H-6 & 47.62 & 85.98 & 95.96 & Tie to & U1418A-10H-4 & 47.74 & 84.42 & 95.96 \\
\hline U1418A-10H-7 & 62.44 & 88.79 & 100.34 & Tie to & U1418D-11H-2 & 69.29 & 89.09 & 100.34 \\
\hline U1418D-11H-6 & 101.20 & 95.41 & 106.65 & Tie to & U1418A-11H-4 & 70.83 & 95.51 & 106.65 \\
\hline U1418A-11H-6 & 99.91 & 98.80 & 109.95 & Tie to & U1418C-15H-1 & 35.14 & 96.65 & 109.95 \\
\hline U1418C-15H-2 & 117.52 & 98.98 & 112.27 & Tie to & U1418E-5H-1 & 76.62 & 97.57 & 112.27 \\
\hline U1418E-5H-6 & 24.30 & 104.54 & 119.25 & Tie to & U1418A-12H-4 & 126.91 & 105.57 & 119.25 \\
\hline U1418A-12H-6 & 115.64 & 108.46 & 122.13 & Tie to & U1418C-17H-1 & 139.00 & 107.09 & 122.13 \\
\hline U1418C-17H-3 & 103.22 & 109.73 & 124.78 & Tie to & U1418E-6H-2 & 21.06 & 108.01 & 124.78 \\
\hline U1418E-6H-6 & 124.35 & 115.04 & 131.81 & Tie to & U1418D-14H-1 & 66.47 & 115.96 & 131.81 \\
\hline U1418D-14H-5 & 129.68 & 122.60 & 138.44 & Tie to & U1418C-20H-4 & 84.68 & 122.89 & 138.44 \\
\hline U1418C-20H-6 & 145.16 & 126.37 & 141.93 & Tie to & U1418D-15H-1 & 137.41 & 124.17 & 141.93 \\
\hline U1418D-15H-3 & 129.88 & 127.10 & 144.85 & Tie to & U1418C-21H-1 & 78.36 & 128.48 & 144.85 \\
\hline U1418C-21H-6 & 81.96 & 136.02 & 152.39 & Tie to & U1418D-16H-1 & 90.06 & 133.20 & 152.39 \\
\hline U1418D-16H-5 & 50.71 & 138.81 & 157.99 & Tie to & U1418C-22H-2 & 105.45 & 139.75 & 157.99 \\
\hline U1418C-22H-6 & 107.17 & 145.78 & 164.02 & Tie to & U1418D-17H-1 & 86.41 & 142.66 & 164.02 \\
\hline U1418D-17H-6 & 68.15 & 149.63 & 170.99 & Tie to & U1418C-23H-2 & 116.80 & 149.37 & 170.99 \\
\hline U1418C-23H-5 & 119.84 & 153.90 & 175.52 & Tie to & U1418D-18H-1 & 113.78 & 152.44 & 175.52 \\
\hline U1418D-18H-4 & 115.33 & 156.95 & 180.03 & Tie to & U1418C-24H-1 & 61.32 & 155.91 & 180.03 \\
\hline U1418C-24H-5 & 104.10 & 162.34 & 186.46 & Tie to & U1418D-19H-2 & 21.69 & 162.52 & 186.46 \\
\hline U1418D-19H-5 & 111.48 & 167.91 & 191.86 & Tie to & U1418C-25H-1 & 98.96 & 165.79 & 191.86 \\
\hline U1418C-25H-6 & 103.25 & 173.33 & 199.40 & Tie to & U1418D-20H-3 & 13.82 & 173.45 & 199.40 \\
\hline U1418D-20H-5 & 99.64 & 177.34 & 203.29 & Tie to & U1418C-26H-1 & 101.25 & 175.01 & 203.29 \\
\hline U1418C-26H-5 & 48.86 & 180.49 & 208.77 & Tie to & U1418D-21H-1 & 72.87 & 180.53 & 208.77 \\
\hline U1418D-21H-5 & 108.17 & 186.88 & 215.12 & Tie to & U1418C-27H-1 & 132.51 & 184.83 & 215.12 \\
\hline U1418C-27H-6 & 7.63 & 191.08 & 221.37 & Tie to & U1418D-22H-1 & 110.03 & 190.20 & 221.37 \\
\hline U1418D-22H-4 & 86.24 & 194.35 & 225.52 & Tie to & U1418C-28H-2 & 55.24 & 193.95 & 225.52 \\
\hline U1418C-28H-5 & 138.91 & 199.29 & 230.86 & Tie to & U1418D-23H-1 & 71.09 & 197.11 & 230.86 \\
\hline U1418D-23H-5 & 60.32 & 202.90 & 236.65 & Tie to & $\mathrm{U} 1418 \mathrm{C}-29 \mathrm{H}-1$ & 73.97 & 202.14 & 236.65 \\
\hline U1418C-29H-4 & 55.34 & 206.45 & 240.97 & Tie to & U1418D-24H-1 & 78.00 & 204.58 & 240.97 \\
\hline U1418D-24H-5 & 107.15 & 210.87 & 247.26 & Tie to & U1418C-30H-1 & 132.62 & 211.03 & 247.26 \\
\hline U1418C-30H-4 & 80.57 & 215.01 & 251.24 & Tie to & U1418D-25H-1 & 71.16 & 212.51 & 251.24 \\
\hline U1418D-25H-6 & 26.69 & 219.57 & 258.29 & Tie to & U1418C-31H-1 & 131.51 & 219.52 & 258.29 \\
\hline U1418C-31H-5 & 23.52 & 223.94 & 262.71 & Tie to & U1418D-26H-1 & 73.81 & 221.34 & 262.71 \\
\hline U1418D-26H-1 & 73.81 & 221.34 & 262.71 & Append & U1418D-26H-6 & 152.00 & 229.63 & 271.00 \\
\hline
\end{tabular}

Tie points in bold reflect tentative correlations. See text for details. 
Table T12. Position of the top (T) and bottom (B) of polarity transitions identified at Site U1418.

\begin{tabular}{lclccc}
\hline Polarity chron interpretation & $\begin{array}{c}\text { Age } \\
(\mathrm{Ma})\end{array}$ & & $\begin{array}{c}\text { Core, section, } \\
\text { interval (cm) }\end{array}$ & $\begin{array}{c}\text { Depth } \\
\text { CSF-A (m) }\end{array}$ & $\begin{array}{c}\text { Depth } \\
\text { CCSF-B (m) }\end{array}$ \\
\hline & & \multicolumn{3}{c}{ 341-U1418F- } \\
C1n (B) Matuyama/Brunhes & 0.781 & $\begin{array}{l}\text { Top } \\
\text { 41R-5, 115 }\end{array}$ & 645.43 & 645.43 \\
& & Base & $44 \mathrm{R}-1,15$ & 668.10 & 668.10 \\
C1r.1n (T) Jaramillo & \multirow{2}{*}{0.988} & Top & $57 \mathrm{R}-6,55$ & 801.58 & 801.58 \\
& & Base & $58 \mathrm{R}-5,75$ & 809.89 & 809.88 \\
C1r.1n (B) Jaramillo & \multirow{2}{*}{1.072} & Top & $62 \mathrm{R}-2,90$ & 844.25 & 844.25 \\
& & Base & $62 \mathrm{R}-4,35$ & 846.35 & 846.35 \\
\hline
\end{tabular}

$B=$ bottom,$T=$ top

Table T13. Shipboard age-depth models and sedimentation rates, Site U1418.

\begin{tabular}{cccccccccc}
\hline $\begin{array}{c}\text { Age } \\
(\mathrm{Ma})\end{array}$ & $\begin{array}{c}\text { Average } \\
\text { depth } \\
\text { CCSF-A }(\mathrm{m})\end{array}$ & $\begin{array}{c}\text { Minimum } \\
\text { depth } \\
\text { CCSF-A }(\mathrm{m})\end{array}$ & $\begin{array}{c}\text { Maximum } \\
\text { depth } \\
\text { CCSF-A }(\mathrm{m})\end{array}$ & $\begin{array}{c}\text { Average } \\
\text { depth } \\
\text { CCSF-B }(\mathrm{m})\end{array}$ & $\begin{array}{c}\text { Minimum } \\
\text { depth } \\
\text { CCSF-B }(\mathrm{m})\end{array}$ & $\begin{array}{c}\text { Maximum } \\
\text { depth } \\
\text { CCSF-B }(\mathrm{m})\end{array}$ & $\begin{array}{c}\text { Average } \\
\text { sed. rate } \\
(\mathrm{m} / \mathrm{m} . \mathrm{y} .)\end{array}$ & $\begin{array}{c}\text { Minimum } \\
\text { sed. rate } \\
(\mathrm{m} / \mathrm{m} . \mathrm{y} .)\end{array}$ & $\begin{array}{c}\text { Maximum } \\
\text { sed. rate } \\
(\mathrm{m} / \mathrm{m} . \mathrm{y} .)\end{array}$ \\
\hline 0.0 & 0.0 & 0.0 & 0.0 & 0.0 & 0.0 & 0.0 & 1275 & 1041 & 1505 \\
0.2 & 297.1 & 184.8 & 392.1 & 255.0 & 160.0 & 350.0 & 1275 & 1041 & 1505 \\
0.2 & 297.1 & 184.8 & 392.1 & 255.0 & 160.0 & 350.0 & 825 & 484 & 1139 \\
0.4 & 462.1 & 362.1 & 562.1 & 420.0 & 320.0 & 520.0 & 825 & 484 & 1139 \\
0.4 & 462.1 & 362.1 & 562.1 & 420.0 & 320.0 & 520.0 & 575 & 216 & 939 \\
0.6 & 577.1 & 482.1 & 672.1 & 535.0 & 440.0 & 630.0 & 575 & 216 & 939 \\
0.6 & 577.1 & 482.1 & 672.1 & 535.0 & 440.0 & 630.0 & 688 & 448 & 949 \\
0.8 & 714.6 & 692.1 & 737.1 & 672.5 & 650.0 & 695.0 & 688 & 448 & 949 \\
0.8 & 714.6 & 692.1 & 737.1 & 672.5 & 650.0 & 695.0 & 738 & 660 & 818 \\
1.0 & 862.1 & 842.1 & 882.1 & 820.0 & 800.0 & 840.0 & 738 & 660 & 818 \\
1.0 & 862.1 & 842.1 & 882.1 & 820.0 & 800.0 & 840.0 & 450 & 345 & 563 \\
1.2 & 952.1 & 912.1 & 982.1 & 910.0 & 870.0 & 940.0 & 450 & 345 & 563 \\
\hline
\end{tabular}

Table T14. Alternating field demagnetization steps used, Site U1418.

\begin{tabular}{lll}
\hline Hole & Cores undertaken & $\begin{array}{c}\text { AF demagnetization } \\
\text { steps }(\mathrm{mT})\end{array}$ \\
\hline U1418A & All cores & $0,10,20$ \\
U1418B & Section 1H-1 & $0,10,15,20$ \\
U1418B & Sections 1H-2, 1H-3 & $0,5,10,15,20$ \\
U1418B & All other cores & $0,10,20$ \\
U1418C & Sections 1H-1, 1H-2, 1H-3 & $0,5,10,15,20$ \\
U1418C & All other cores & $0,10,20$ \\
U1418D & All cores & $0,10,20$ \\
U1418E & All cores & $0,10,20$ \\
U1418F & Sections 58R-3, 58R-4, 58R-5, 58R-6, 59R-1, 59R-2, 59R-3, 59R-4, 59R-5, 62R-3, 62R-4 & $0,5,10,15,20$ \\
U1418F & Section 68R-1 & $0,10,20,25,30$ \\
U1418F & All other cores & $0,10,20$ \\
\hline
\end{tabular}

